\title{
Post-flood recovery and distributions of fishes in the New River Gorge National River, West Virginia
}

David I. Wellman Jr.

West Virginia University

Follow this and additional works at: https://researchrepository.wvu.edu/etd

\section{Recommended Citation}

Wellman, David I. Jr., "Post-flood recovery and distributions of fishes in the New River Gorge National River, West Virginia" (2004). Graduate Theses, Dissertations, and Problem Reports. 2001.

https://researchrepository.wvu.edu/etd/2001

This Thesis is protected by copyright and/or related rights. It has been brought to you by the The Research Repository @ WVU with permission from the rights-holder(s). You are free to use this Thesis in any way that is permitted by the copyright and related rights legislation that applies to your use. For other uses you must obtain permission from the rights-holder(s) directly, unless additional rights are indicated by a Creative Commons license in the record and/ or on the work itself. This Thesis has been accepted for inclusion in WVU Graduate Theses, Dissertations, and Problem Reports collection by an authorized administrator of The Research Repository @ WVU. For more information, please contact researchrepository@mail.wvu.edu. 
Post-flood recovery and distributions of fishes in the New River Gorge National River, West Virginia

David I. Wellman, Jr.

Thesis submitted to the Davis College of Agriculture, Forestry, and Consumer Sciences at West Virginia University in partial fulfillment of the requirements

for the degree of

Master of Science

in

Wildlife and Fisheries Resources

\author{
Stuart A. Welsh, Ph.D., Chair \\ Douglas B. Chambers, B.S. \\ Kyle J. Hartman, Ph.D. \\ J. Todd Petty, Ph.D. \\ Jesse Purvis, Ph.D.
}

Division of Forestry

Morgantown, WV

2004

Keywords: flood, drought, nonnative fish, fish recovery, New River fish distributions, New River Gorge National River 


\section{ABSTRACT \\ Post-Flood Recovery and distributions of fishes in the New River Gorge National River, West Virginia}

\section{David I. Wellman, Jr.}

The following thesis contains three chapters. The first chapter introduces and reviews literature on disturbances in streams (e.g. flood and drought), recovery of impacted lotic systems, introduced species and New River fish distributions. Chapter 2 provides a synthesis of native and nonnative fish distribution data of the New River Gorge National River (NRGNR). Sixtytwo species were documented within or near the NRGNR. Thirty-one (50\%) are considered nonnative. The third chapter consists of a study that estimated seasonal abundances of native and nonnative fishes in small tributaries of NRGNR during a 20 month time period following July 2001 floods, and examined among-season stability in abundances of native and nonnative fishes across the 20-month time series. Twenty-nine species were observed (15 native and 14 nonnative) and patterns of recovery were influenced primarily by four natives (stoneroller, blacknose, dace, creek chub, and green sunfish) and four nonnatives (telescope shiner, whitetail shiner, smallmouth bass, and rainbow darter). Abundances of most species did not increase monotonically over the 20-month study period, but fluctuated among seasons. Abundances of nonnative fishes were generally less stable than those of natives across the 20-month time series. Seasonal variation in abundances among species was attributed to historic ecological factors, summer drought, immigration and emigration associated with seasonal habitat shifts, and juvenile recruitment. 


\section{DEDICATION}

To my grandparents, Ira and Irene Wellman and my wonderful wife and son, Stacy and Garrett. 


\section{ACKNOWLEDGEMENTS}

I would like to thank the members of my graduate committee, Dr. J. Todd Petty, Dr. Kyle Hartman, Dr. Jesse Purvis, and Mr. Doug Chambers for guidance and review of my project. Dr. Stuart Welsh, my chair advisor, was an excellent mentor and I offer sincere thanks for your guidance.

Thanks goes to Mrs. Becky Nestor, because without you my graduate experience would have been less enjoyable and much more stressful. Thank you Lara Hedrick, Jim Hedrick, Steve Hammond, Ben Lenz, Elizabeth Osier, Chris Nelson, Karen Vandersall and Jessica Smith for collecting data over long days in rough terrain. Thank you George Siedel for statistical expertise.

Special thanks to my wife Stacy whose patience, encouragement, and love helped me complete this educational endeavor. Thanks are also extended to my son Garrett. Hopefully, we can now have a few more evenings and weekends to enjoy each other's company. I would also like to thank Albert and Emogene Grady for being very helpful in so many ways.

Thanks to Walt Kordek of the West Virginia Division of Natural Resources (WVDNR) for providing fish distribution data and to Dan Cincotta of the WVDNR for review of this thesis and also supplying important distributional information. Finally, I would like to thank the U.S. Geological Survey - West Virginia Cooperative Fish and Wildlife Research Unit and the West Virginia University Division of Forestry for providing the opportunity for graduate education and the National Park Service - New River Gorge National River for funding this project. 


\section{TABLE OF CONTENTS}

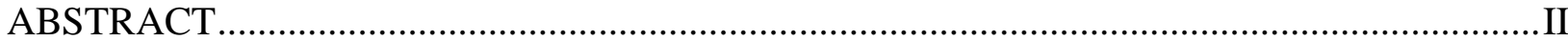

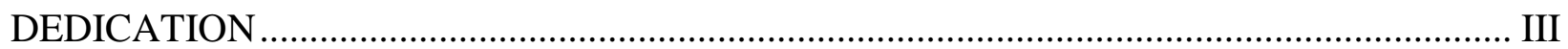

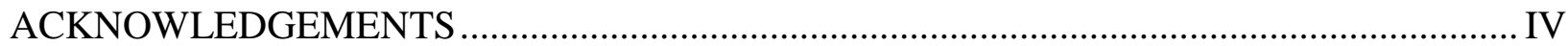

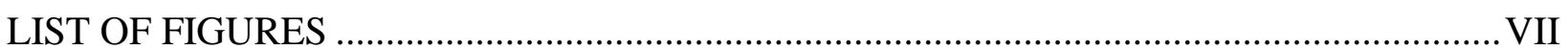

LIST OF TABLES.............................................................................

LIST OF APPENDICES..................................................................

CHAPTER 1: INTRODUCTION AND LITERATURE REVIEW ………………………........... 1

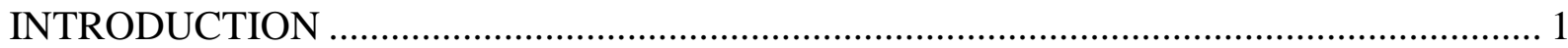

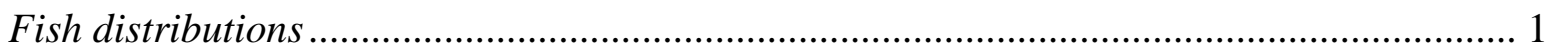

Flood, drought, and fish recolonization ............................................................................ 1

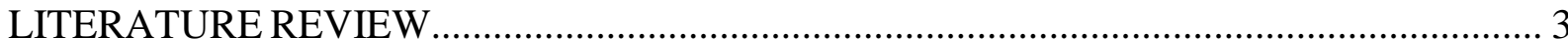

New River Fish Distributions..................................................................................... 3

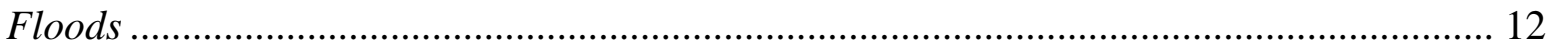

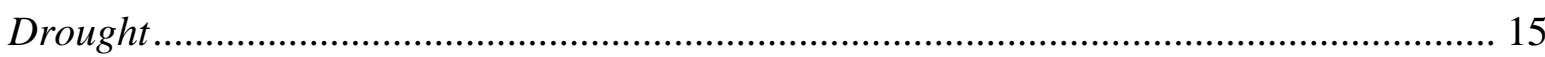

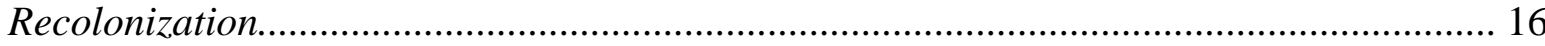

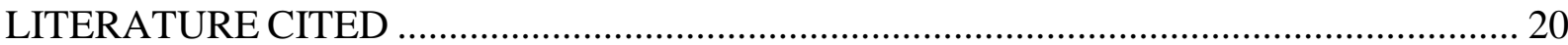

CHAPTER 2: ICHTHYOFAUNA OF THE NEW RIVER GORGE NATIONAL RIVER, WEST

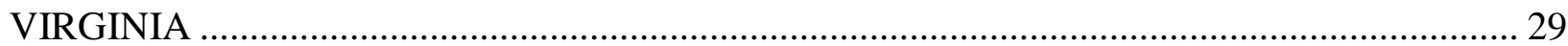

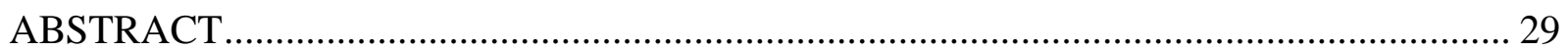

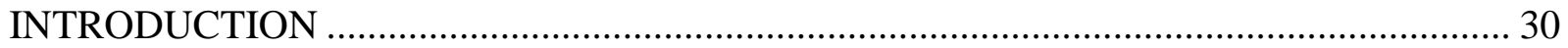

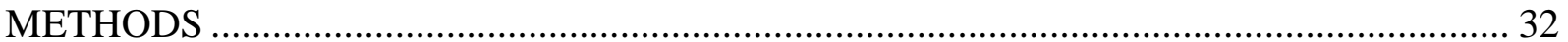

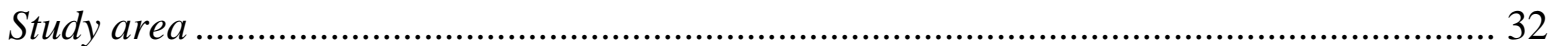

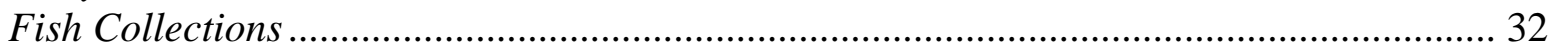

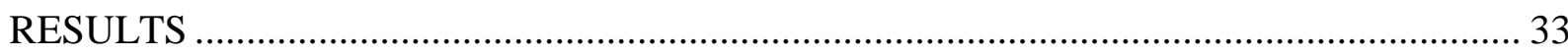

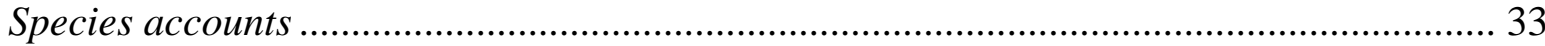

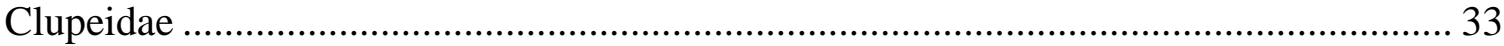

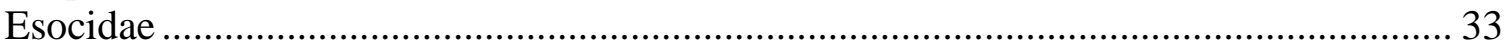

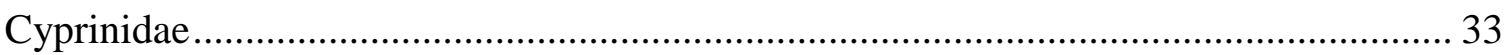

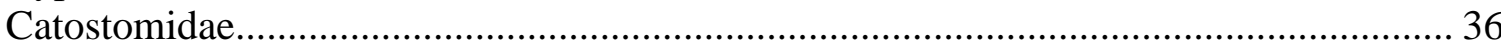

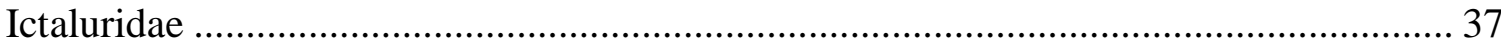

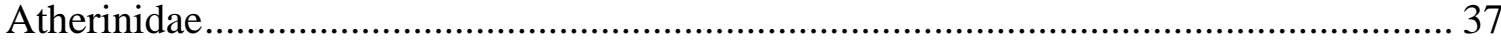

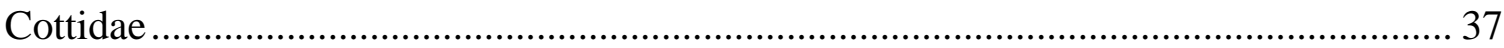

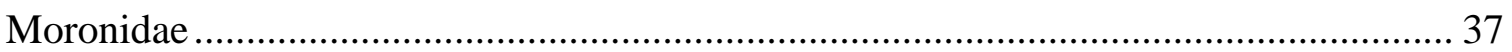

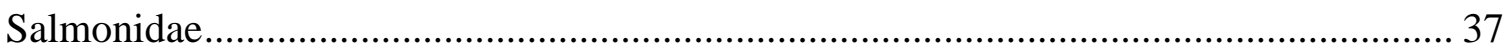

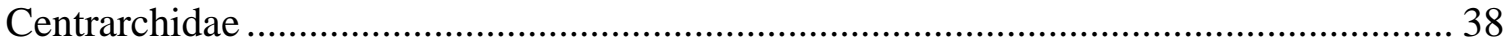

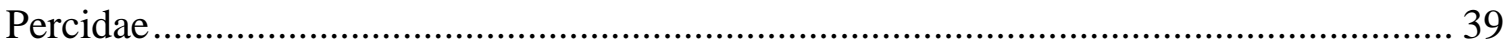

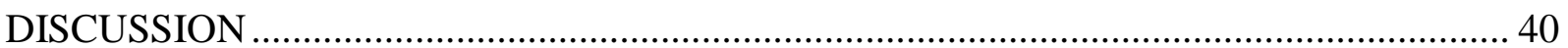

Extirpation and population declines of native species ........................................................ 41

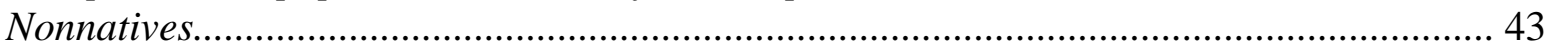

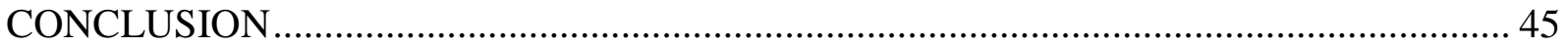

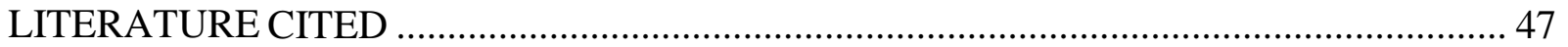


CHAPTER 3: POST-FLOOD RECOLONIZATION OF NATIVE AND NONNATIVE FISHES IN TRIBUTARIES WITHIN NEW RIVER GORGE NATIONAL RIVER, WEST VIRGINIA

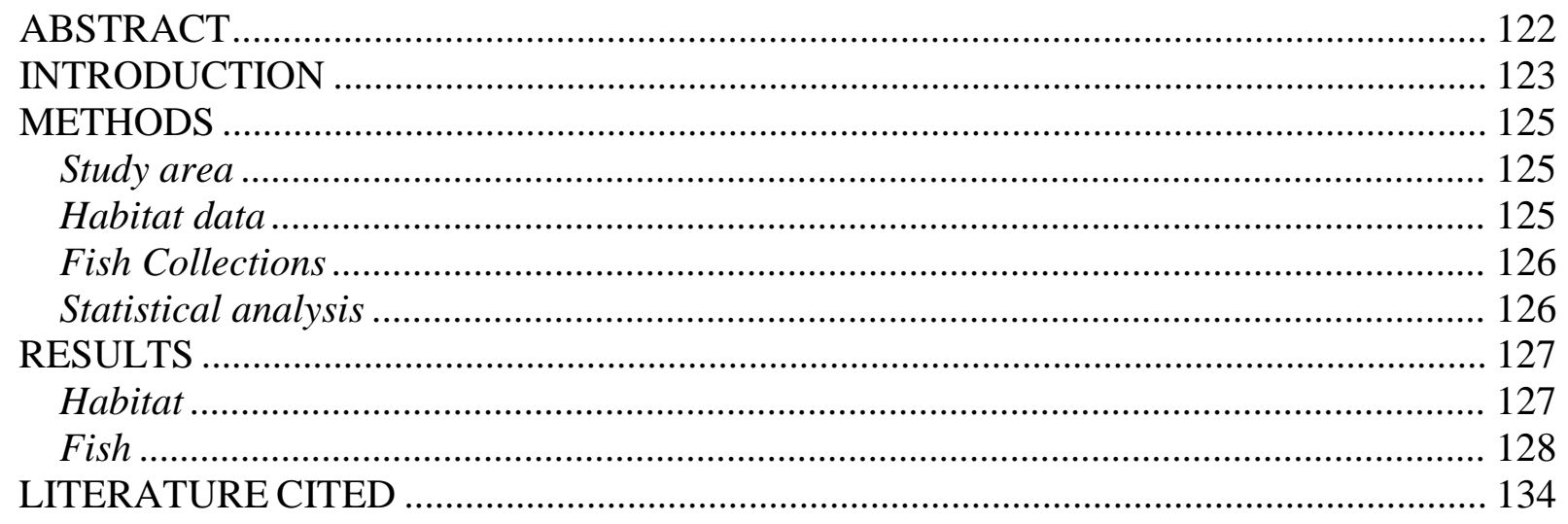




\section{LIST OF FIGURES}

\section{Chapter 2}

Figure 1. Location of New River Gorge National River in southern West Virginia.

Figure 2. Sites of fish collections (1928 - 2003) within or near the New River Gorge National River.

Figure 3. Collection sites for Dorosoma cepedianum (gizzard shad) within and near the New

River Gorge National River.

Figure 4. Collection sites for Esox masquinongy (muskellunge) within and near the New River Gorge National River.

Figure 5. Collection sites for Campostoma anomalum (central stoneroller) within and near the New River Gorge National River.

Figure 6. Collection sites for Clinostomus funduloides (rosyside dace) within and near the New River Gorge National River.

Figure 7. Collection sites for Cyprinella galactura (whitetail shiner) within and near the New River Gorge National River.

Figure 8. Collection sites for Cyprinella spiloptera (spotfin shiner) within and near the New River Gorge National River.

Figure 9. Collection sites for Cyprinus carpio (common carp) within and near the New River Gorge National River..

Figure 10. Collection sites for Ericymba buccata (silverjaw minnow) within and near the New River Gorge National River.

Figure 11. Collection sites for Erimystax dissimilis (streamline chub) within and near the New River Gorge National River.

Figure 12. Collection sites for Exoglossum laurae (tonguetied minnow) within and near the New River Gorge National River.

Figure 13. Collection sites for Luxilus albeolus (white shiner) within and near the New River Gorge National River.

Figure 14. Collection sites for Luxilus chrysocephalus (striped shiner) within and near the New River Gorge National River. 
Figure 15. Collection sites for Nocomis platyrhynchus (bigmouth chub) within and near the New River Gorge National River.............................................................................................. 73

Figure 16. Collection sites for Notemigonus crysoleucas (golden shiner) within and near the New River Gorge National River.

Figure 17. Collection sites for Notropis hudsonius (spottail shiner) within and near the New River Gorge National River....................................................................................... 75

Figure 18. Collection sites for Notropis photogenis (silver shiner) within and near the New River

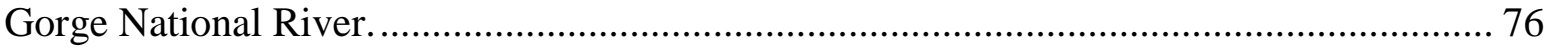

Figure 19. Collection sites for Notropis rubellus (rosyface shiner) within and near the New River Gorge National River............................................................................................... 77

Figure 20. Collection sites for Notropis scabriceps (New River shiner) within and near the New River Gorge National River......................................................................................... 78

Figure 21. Collection sites for Notropis stramineus (sand shiner) within and near the New River Gorge National River. 79

Figure 22. Collection sites for Notropis telescopus (telescope shiner) within and near the New River Gorge National River.............................................................................................. 80

Figure 23. Collection sites for Notropis volucellus (mimic shiner) within and near the New River Gorge National River. 81

Figure 24. Collection sites for Phoxinus oreas (mountain redbelly dace) within and near the New River Gorge National River. ................................................................................. 82

Figure 25. Collection sites for Pimephales notatus (bluntnose minnow) within and near the New River Gorge National River. 83

Figure 26. Collection site for Pimephales promelas (fathead minnow) within the New River Gorge National River.

Figure 27. Collection sites for Rhinichthys atratulus (blacknose dace) within and near the New River Gorge National River.

Figure 28. Collection sites for Rhinichthys cataractae (longnose dace) within or near the New River Gorge National River.

Figure 29. Collection sites for Semotilus atromaculatus (creek chub) within and near the New River Gorge National River. 
Figure 30. Collection sites for Catostomus commersoni (white sucker) within and near the New

River Gorge National River. 88

Figure 31. Collection sites for Hypentelium nigricans (northern hogsucker) within and near the New River Gorge National River.

Figure 32. Collection sites for Ameiurus natalis (yellow bullhead) within and near the New River Gorge National River.

Figure 33. Collection sites for Ictalurus punctatus (channel catfish) within and near the New River Gorge National River.

Figure 34. Collection sites for Pylodictis olivaris (flathead catfish) within and near the New

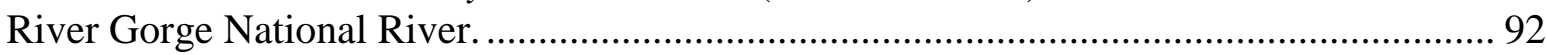

Figure 35. Collection sites for Labidesthes sicculus (brook silverside) within and near the New River Gorge National River.......................................................................................... 93

Figure 36. Collection sites for Cottus bairdi (mottled sculpin) within and near the New River Gorge National River...................................................................................................... 94

Figure 37. Collection sites for Morone chrysops (white bass) within and near the New River Gorge National River................................................................................................ 95

Figure 38. Collection sites for Oncorhynchus mykiss (rainbow trout) within and near the New River Gorge National River.............................................................................................. 96

Figure 39. Collection sites for Salmo trutta (brown trout) within and near the New River Gorge

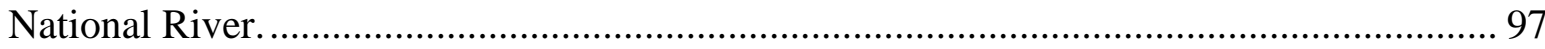

Figure 40. Collection sites for Salvelinus fontinalis (brook trout) within and near the New River Gorge National River.................................................................................................. 98

Figure 41. Collection sites for Ambloplites rupestris (rock bass) within and near the New River Gorge National River................................................................................................ 99

Figure 42. Collection sites for Lepomis auritus (redbreast sunfish) within and near the New River Gorge National River....................................................111

Figure 43. Collection sites for Lepomis cyanellus (green sunfish) within and near the New River Gorge National River ........................................................................................................ 101

Figure 44. Collection sites for Lepomis gibbosus (pumpkinseed) within and near the New River Gorge National River. 102 
Figure 45. Collection sites for Lepomis macrochirus (bluegill) within and near the New River Gorge National River. 103

Figure 46. Collection sites for Lepomis megalotis (longear sunfish) within and near the New River Gorge National River. 104

Figure 47. Collection sites for Micropterus dolomieu (smallmouth bass) within and near the New River Gorge National River.

Figure 48. Collection sites for Micropterus punctulatus (spotted bass) within and near the New River Gorge National River. 106

Figure 49. Collection sites for Micropterus salmoides (largemouth bass) within and near the New River Gorge National River.

Figure 50. Collection sites for Pomoxis annularis (white crappie) within and near the New River Gorge National River........................................................................................... 108

Figure 51. Collection sites for Pomoxis nigromaculatus (black crappie) within and near the New River Gorge National River........................................................................................... 109

Figure 52. Collection sites for Etheostoma blennioides (greenside darter) within and near the New River Gorge National River. ................................................................................ 110

Figure 53. Collection sites for Etheostoma caeruleum (rainbow darter) within and near the .New River Gorge National River...............................................121

Figure 54. Collection sites for Etheostoma flabellare (fantail darter) within and near the New

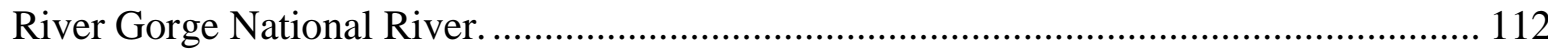

Figure 55. Collection sites for Etheostoma nigrum (johnny darter) within and near the New River Gorge National River.

Figure 56. Collection sites for Etheostoma variatum (variegate darter) within and near the New River Gorge National River............................................................................................. 114

Figure 57. Collection sites for Percina caprodes (logperch) within and near the New River Gorge National River............................................................................................. 115

Figure 58. Collection sites for Percina maculata (blackside darter) within and near the New River Gorge National River.

Figure 59. Collection sites for Percina oxyrhynchus (sharpnose darter) within and near the New River Gorge National River. 
Figure 60. Collection sites for Percina roanoka (Roanoke darter) within and near the New River Gorge National River.

Figure 61. Collection sites for Perca flavescens (yellow perch) within and near the New River

Gorge National River.

Figure 62. Collection sites for Sander vitreus (walleye) within and near the New River Gorge National River.

Figure 63. Collection sites for Scardinius erythrophthalmus (European rudd) within and near the New River Gorge National River. 121

\section{Chapter 3}

Figure 1. Location of New River Gorge National River in southern West

Virginia

Figure 2. Location of twelve recolonization study sites in the New River Gorge

National River.

Figure 3. Estimated seasonal abundances of nonnative and native fishes in flood-impacted and reference reaches of tributaries in New River Gorge, West Virginia. ...

Figure 4. Abundances of dominant nonnative (first column) and native (second column) species in flood-impacted (closed bars) and reference (open bars) reaches of tributaries in New River Gorge, West Virginia, during five consecutive sampling seasons $(1=$ fall 2001, 2 = spring 2002, $3=$ summer 2002, $4=$ fall 2002, and $5=$ spring 2003).....

Figure 5. Coefficients of variation (CV; representing an axis of temporal stability) of among-season abundances of eight common species in tributaries within New River Gorge National River. A CV of zero represents no among-season variation or the highest level of stability. 


\section{LIST OF TABLES}

\section{Chapter 2}

Table 1. Sites of fish collections within or near the New River Gorge National River

(UMMZ denotes records from University of Michigan Museum of Zoology)....

\section{Chapter 3}

Table 1. Study streams located within the New River Gorge National River (reference streams are asterisked). Slope estimates are for study reaches, not entire streams

Table 2. Total abundances of native $(\mathrm{N}=$ native, $\mathrm{E}=$ endemic, $\mathrm{NI}=$ native, but possibly introduced) and nonnative (I = introduced, IP = probably introduced) species from five

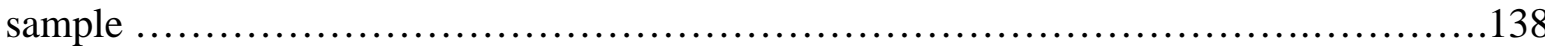

\section{LIST OF APPENDICES}

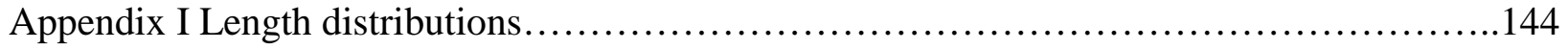

Appendix II Fish distributions for the 12 recolonization study sites........................153

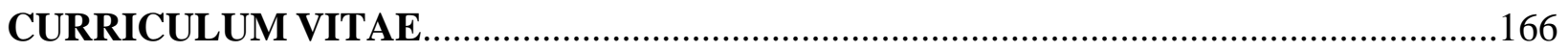




\section{Chapter 1: Introduction and Literature Review}

\section{INTRODUCTION}

This thesis includes two manuscripts on studies of fishes within the New River Gorge, West Virginia. The first study (Chapter 2) synthesizes historic and current distribution data of native and nonnative fishes within the New River Gorge. In the second study (Chapter 3), the species order and timing of post-flood recolonization of fishes in the New River Gorge were examined. Introductions and literature reviews are provided below.

Fish distributions

An understanding of current and historic fish distributions within the NRGNR is a critical management need for the National Park Service. Previous fish surveys focused largely on the New River mainstem and larger tributaries (see citations below), and indicate a high percentage of nonnative species. I collected fish distribution data from 26 tributaries within park boundaries. A synthesis of fish distribution data from recent and previous surveys (Chapter 3) provides managers of the NRGNR with information on distributions and range expansions of native and nonnative species.

Flood, drought, and fish recolonization

During June and July, flash floods occur commonly on small Appalachian streams after intense late afternoon thunderstorms (Messinger and Hughes 2000). On 8 July 2001 training thunderstorm cells in a mesoscale convective complex caused severe flash floods in southern West Virginia including portions of the New River Gorge National River (NRGNR). Rain accumulation ranged from 76-140 mm within a $3-6$ hour period with maximum rainfall rates of 38-65 mm per hour (NOAA 2003). A second flash flood event on July 26 in the NRGNR resulted from 51-102 mm of rain accumulation within a six-hour period (NOAA 2003). Flood 
waters and debris flows restructured stream channels, scoured streambeds, removed riparian vegetation, created large alluvial fans, and reduced or extirpated fish populations in several tributaries within NRGNR park boundaries

In contrast, West Virginia received below-average rainfall during summer 2002 and ranked $5^{\text {th }}$ in August drought conditions among all states (NOAA 2003). As a result, many tributary reaches within the NRGNR dewatered completely or reduced to isolated pools. Fish populations in these tributaries retreated to the New River mainstem or were confined to isolated pools. Flood and drought events reduced or extirpated fish populations in small, high gradient tributaries of NRGNR, and provided an opportunity to examine recolonization of native and nonnative fishes.

Due to limited pre-flood fish distribution data, little was known about the species composition within the tributaries. Recently introduced species typically undergo fast range expansions, but to what extent they use small tributaries in the NRGNR is unclear. Therefore, I hypothesized there would be differences in species order, timing, richness, and abundances (total and relative) between native and nonnative species. 


\section{LITERATURE REVIEW}

New River Fish Distributions

The New River begins near Blowing Rock, North Carolina, and flows northward 402 km to its confluence with the Gauley River to form the Kanawha River (Wilson and Purvis 2000).

The New River drains approximately 17,918 $\mathrm{km}^{2}$ through the Blue Ridge, Valley and Ridge, and Appalachian Plateau provinces of North Carolina, Virginia and West Virginia, respectively

(Stauffer et al. 1995). The New River is unique in that it is surrounded by nine other large river basins. Claytor, Bluestone, and Hawks Nest are three major impoundments on the New River and four smaller dams occur upstream of Claytor Reservoir. An 85 km section of the New River in southern West Virginia is designated as the New River Gorge National River (NRGNR) and has been administered by the National Park Service since 1978.

Cope (1868), Goldsborough and Clark (1908), Addair (1944), Ross and Perkins (1959), and Ross (1959) completed early studies of the New River's fish fauna. Cope (1868) collected from four New River sites in Virginia. Goldsborough and Clarke (1908) collected from less than 10 sites in the West Virginia portion of the New River (Messinger and Chambers 2001). Not until Addair (1944) was there an extensive basin wide survey of the New River. However, these early collections provided a basis for later surveys and distributional histories of the New River's fish fauna by Jenkins et al. (1972), Hocutt et al. (1978, 1979), Hess 1983, Lobb 1986, Neves (1983), Easton et al. (1993), Easton and Orth (1994), Jenkins and Burkhead (1993), Stauffer et al. (1995), Cincotta et al. (1999), Messinger and Hughes (2000), Paybins et al. (2000), Messinger and Chambers (2001), and the West Virginia Division of Natural Resources (WVDNR). These researchers focused on the New River mainstem or large tributaries and attributed the distribution and species composition of the fauna to many factors such as proximity to rich 
faunas, high gradient, hard bottom, high sulfate levels, spatial differences in geology, water chemistry, stream size, subterranean loss of surface water, water pollution, stream capture, physical barriers, glaciations, and human movement of fishes.

The New River fish fauna is patchily distributed and depauperate with 47 native species (Easton and Orth 1994, Jenkins and Burkhead 1994). The New River system has lower species richness than neighboring drainages and the lowest ratio of species richness to drainage area of the 26 eastern major river drainages (Cincotta et al. 1999). Endemic species known to the New River drainage are Nocomis platyrhynchus (bigmouth chub), Phenacobius teretulus (kanawha minnow), Notropis scabriceps (New River shiner), Percina gymnocephala (Appalachia darter), Etheostoma kanawhae (kanawha darter), Etheostoma osburni (candy darter), and the Bluestone and cave sculpins (Jenkins and Burkhead 1994, Stauffer et al. 1995). The ratio of endemic to native species is second highest to the Mobile drainage (Jenkins and Burkhead 1994).

Species distributions within the New River drainage are influenced by drainage history. The New River follows the course of the ancestral Teays River (Ver Steeg 1945, Janssen 1953). The New River Gorge formed from mountain uplifting and erosion through layers of non-marine shale, sandstone, and limestone and coal of the Mississippian and Pennsylvanian (Swift 2000). The New River Gorge begins near Hinton, WV and extends to the confluence of the New and Gauley Rivers. In several places, the Gorge rim rises more than 300 meters above the river and maximum height is approximately 488 meters (Swift 2000). Geologic processes have created barriers to migration (e.g. Kanawha Falls, Sandstone Falls), powerful rapids, and cascades in the New River Gorge. Such natural barriers have hindered colonization and dispersal and isolated species in the New River system (Neves 1983, McKeown et al. 1984, Jenkins and Burkhead 1994, Messinger and Chambers 2001). The 7.3 m high Kanawha Falls has influenced genetic 
variation of fishes and number of endemics in the New River (Hocutt et al. 1986).

Consequently, separate fish faunas exist above and below Kanawha Falls (Jenkins and Burkhead 1994).

The Teays River, a center of fish evolution and dispersal for the modern Mississippi and Ohio River basins (Ross and Perkins 1959, Jenkins et al. 1972, Hocutt et al. 1978, Neves 1983, McKeown et al. 1984, Hocutt et al. 1986), was altered during the Pleistocene (about two million to eleven thousand years ago). Throughout this age, climate varied between cold glacial and warm interglacial periods and massive glaciers were formed north of the Appalachians. As a result, the Pleistocene glaciers drastically changed the Teays River that was dominant during the Plieocene period (Hocutt et al. 1986). Teays Lake, formed by an ice dam at present day Chillicothe, Ohio, backed up to present day Gauley Bridge, West Virginia (Neves 1983, Lessing 1997). The lake inundated a large portion of the New River Gorge (upstream of Kanawha Falls) and allowed dispersal into the New River drainage (Hocutt et al. 1986). However, extremely cold temperatures may have limited the use of this lake and increased isolation of fishes (Jenkins and Burkhead 1994).

During the last glacial period of the Pleistocene, Appalachian temperatures were cold and dry. Neves (1983) postulated that temperatures extirpated many cold-intolerant species and the upper Teays system served as refugia for cold-water fishes. Jenkins et al. (1972) suggested that these conditions allowed more cool water species to persist and distribute throughout the basin in lower elevations where it is presently uninhabitable by cool water fishes. At one point the Etheostoma variatum complex was distributed widely throughout the Teays and Old Mississippi Rivers (McKeown et al. 1984). However, separation and isolation of the ancestral species during the Pleistocene resulted in five separate species (E. variatum, E. euzonum, E. tetrazonum, E. 
kanawhae, and E. osburni). The latter two species (E. kanawhae and E. osburni) live primarily in separate sections of the modern Kanawha River system, but E. variatum has recently expanded its range into the Gauley River, New River Gorge and Greenbrier River.

Further changes to the fish fauna occurred during post-Pleistocene climatic warming. Cool-water species were isolated to relic populations in tributaries by warmer mainstem temperatures. Five endemic species (Nocomis platyrhyncus, bigmouth chub; Phenacobius teretulus, kanawha minnow; Notropis scabriceps, New River shiner; Percina gymnocephala, Appalachia darter; Etheostoma kanawhae (kanawha darter); Etheostoma osburni; candy darter; and the Bluestone and cave sculpins) and the abundant white sucker (Catostomus commersoni) prefer cool to cold-water temperatures (Jenkins and Burkhead 1994). Also, a proportionately high number of Cottus taxa occur in the New River system (4 Cottus to 47 natives). Warm water species (abundant in adjacent drainages) are absent or patchily distributed in the New River system (Jenkins and Burkhead 1994). Jenkins et al. (1972) suggested that warm water species moved downstream in search of warmer water temperatures, but were denied re-entry into the system by Kanawha Falls. Climatic change associated with the Pleistocene period and barriers to migration (e.g. Kanawha Falls) are most likely responsible for the high percentage of endemics and the relatively depauperate New River fish fauna (Neves 1983, Jenkins and Burkhead 1994).

Historically throughout the central Appalachians, stream piracy influenced the inbound and outbound dispersal of fishes into the New River system (Neves 1983, Jenkins et al. 1972, Hocutt et al. 1986, Jenkins and Burkhead 1994). Stream piracy is the geological process of one stream capturing the water of another through erosion. During the Pleistocene, streams had more efficient erosive competency due to higher velocities, which led to a high rate of stream captures 
(Ross 1969). Atlantic slope streams captured several headwater streams of the upper Teays River during episodes of stream piracy (e.g. James and Roanoke Rivers). Peripheral populations isolated in Atlantic slope drainages resulted from stream capture, and led to speciation and subsequent dispersal (Neves 1983). Stream piracy events between the New River system and Tennessee and Cumberland drainages have also been suggested (Jenkins and Burkhead 1994). Stream piracy is a natural process. Hence, fishes that enter into new drainages via stream capture should be considered native. Captured streams give up more species than they receive. This may partially account for the depauperate nature of the New River's fish fauna (Hocutt et al. 1986). However, Phoxinus oreas (mountain redbelly dace), Clinostomus funduloides (rosyside dace), Ericymba buccata (silverjaw minnow), and Etheostoma blennioides (greenside darter) possibly entered into New River via stream capture (Hocutt et al. 1986, Jenkins and Burkhead 1994).

Fish introductions are common in aquatic systems throughout the United States (Fuller et al. 1999). Many are accidental releases, while others are committed intentionally for forage, bait, or sport (Easton et al. 1993, Jenkins and Burkhead 1994, Cincotta et al. 1999, Fuller et al. 1999). The success of fish species introductions depends on system complexity, number of native species, reproductive success of introduced species, size selection of predators on native and introduced species, and competitive interactions between species (Ross 1991, Moyle and Light 1996). Areas with low species richness and a high availability of resources are often prone to successful fish introductions (Hocutt and Hambrick 1973). Nonnatives impact native species through habitat alterations, disease/parasite introductions, hybridization, trophic alterations, and spatial alterations (Ross 1991). 
Current literature lists 89 fish species in the New River system (47 native and 42 introduced). This is the largest number and proportion of introduced species in the eastern and central North American drainages (Jenkins and Burkhead 1994). Based on early surveys by Cope (1868), only five predator species of appreciable size existed in the New River system before introductions: Anguilla rostrata (American eel), Ictalurus punctatus (channel catfish), Pylodictis olivaris (flathead catfish), Salvelinus fontinalis (brook trout), and Lepomis cyanellus (green sunfish). Jenkins and Burkhead (1994) referenced the Virginia Fish Commission (VFC) as saying that the New River "has in its main stream little else (gamefishes) than the cat fish.” Consequently, several game and food fishes have been introduced into the New River. Popular game species introduced by the VFC and WVDNR in the New River system are Sander vitreum (walleye), Oncorhynchus mykiss (rainbow trout), Salmo trutta (brown trout), Morone chrysops (white bass), Morone saxatilis (striped bass) and Esox masquinongy (muskellunge) (Easton and Orth 1994, Jenkins and Burkhead 1994). Three species of bullhead catfishes (Ameiurus natalis, yellow bullhead; Ameiurus nebulosus,brown bullhead and Ameiurus melas, black bullhead) were introduced to portions of the New River drainage (Jenkins and Burkhead 1994). The VFC introduced Micropterus dolomieu (smallmouth bass) into New River tributaries in the late 1870's. Ambloplites rupestris (rock bass) was also introduced into the New River by the VFC in 1875 (Jenkins and Burkhead 1994). According to surveys conducted by Goldsborough and Clark (1908), M. dolomieu and A. rupestris quickly expanded their ranges further into West Virginia's portion of the New River. Other game fishes, such as Lepomis sp. were probably stocked after black bass. The first available record that Jenkins and Burkhead (1994) have of the Lepomis macrochirus (bluegill), the most widely introduced Lepomis sp., was in 1936. 
Currently, 12 centrarchids occur in the New River drainage, but Lepomis cyanellus is native representative in the New River (Jenkins and Burkhead 1994).

Of the non-game fishes in the New River system, nearly half are introduced (Jenkins and Burkhead 1994). Dorosoma petenense (threadfin shad) and Notropis atherinoides (emerald shiner) were stocked in reservoirs as forage fish (Easton and Orth 1994). Other nonnatives, probably introduced as forage fishes, include Alosa pseudoharengus (alewife), Pimephales promelas (fathead minnow), and Labidesthes sicculus (brook silverside). According to Easton and Orth (1994), private citizens may have introduced Dorosoma cepedianum (gizzard shad) into Claytor Reservoir, Virginia. Cincotta et al. (1999), Paybins et al. (2000), and Messinger and Chambers (2001) reported recent range expansions of nonnative species, such as Cyprinella galactura (whitetail shiner) and Notropis telescopus (telescope shiner) in the New River system. N. telescopus, native to the Tennessee River drainage, has occurred in the New River system since 1958 (Jenkins and Burkhead 1994). It was first reported from West Virginia by Hambrick et al. (1973) and has since expanded its range within the New River system (Cincotta et al. 1999). C. galactura, also native to the Tennessee River drainage, was first reported for the New River system in 1954 (Ross and Carico 1963, Jenkins and Burkhead 1994). Populations were reported from the mainstem and tributaries of the New River, Virginia, and upper sections of West Virginia (Jenkins et al. 1972, Hess 1983). However, it was not reported from NRGNR until 1988 - 1990 (Easton and Orth 1994). Phoxinus erthrogaster (southern redbelly dace), collected from a Gauley River tributary in 2003 (Welsh et al. 2003), represents an addition to the nonnative species list of the New River drainage or waters above Kanawha Falls.

Jenkins and Burkhead (1994) indicate the New River drainage harbors 12 species of darters; four of these species Etheostoma caeruleum, Etheostoma olmstedi (tessellated darter), 
Etheostoma simoterum (snubnose darter), and Percina roanoka, were considered as introduced or possibly introduced into the New River system. E. caeruleum and P. roanoka occur within NRGNR; E. omstedi the Little River system of North Carolina; and E. simoterum Wolf Creek, Virginia, and the upper Bluestone drainage, Viriginia and West Virginia. P. roanoka were first collected in the New River drainage in 1963 (Ross 1969, Hocutt and Hambrick 1973) at a site between Claytor Dam and Bluestone Reservoir (Jenkins and Burkhead 1994). In 1970 it was collected for the first time in West Virginia at the mouth of the Greenbrier River and was considered the most abundant darter within 20 river km downstream of Bluestone Dam (Jenkins and Burkhead 1994). E. caeruleum are considered as possibly native to portions of the New River (Jenkins and Burkhead 1994, Stauffer et al. 1995). Hocutt and Hambrick (1973) documented the first record from above Kanawha Falls (New River near the mouth of East River). A population of rainbow darters occurred in the lower Gauley system in West Virginia since at least 1976 (Hocutt et al. 1979). The species was considered rare in the New River drainage, Virginia, by Jenkins and Burkhead (1994). The remaining eight darters, including Etheostoma blennioides, Etheostoma flabellare (fantail darter), Etheostoma nigrum (johnny darter), Etheostoma kanawhae (Kanawha darter), Etheostoma osburni, Percina caprodes (logperch), Percina gymnocephala, and Percina oxyrhynchus (sharpnose darter) are considered native. Since 1994, two other darter species have been collected from the New River in West Virginia; these species are Etheostoma variatum and Percina maculata (blackside darter). The variegate darter is native to the Ohio River basin, but was previously absent upstream of Kanawha Falls in the New River drainage (Jenkins and Burkhead 1994). Recent collections, however, documented variegate darter above Kanawha Falls (Cincotta et al. 1999, Messinger and Chambers 2001; data reported herein), adding another introduced species to the list. Most 
historic records for Percina maculata are now recognized as P. gymnocephala following the species description of the latter in 1980; Stauffer et al. (1995) indicate $P$. maculata as being present throughout the Gauley River and at the mouth of Piney Creek in NRGNR. Due to recent collections in Gauley (Welsh et al. 2003), which produced only P. gymnocephala, the Gauley River records for P. maculata may be regarded as P. gymnocephala (D. A. Cincotta pers. comm.). However, recently confirmed records of blackside darter within the upper Piney Crek watershed by Cincotta (unpublished data), suggest the Stauffer et al. (1995) record from lower Piney Creek is valid.

Water chemistry and productivity influence fish distributions and success of introduced fishes. Variations occur in water chemistry and productivity among the Blue Ridge, Valley and Ridge, and Appalachian Plateau provinces of the New River basin due to geological differences (Jenkins and Burkhead 1994) and land uses (Paybins et al. 2000). The New River Gorge is inherently unproductive due to sandstone dominated geology and this may partially account for low species abundance in this particular section of the river. Human practices such as coal mining, domestic waste, logging, agriculture, industrial activities, urbanization, and oil/gas extraction have influenced water quality throughout the New River basin (Addair 1944, Messinger and Hughes 2000, Wilson and Purvis 2000). Fecal coliform counts are typically high within smaller tributaries of the NRGNR (Wood 1990, Wilson and Purvis 2000) owing to inadequate sewage treatment plants and untreated sewage inputs. Sewage increases productivity, turbidity, conductivity and fish anomalies, and alters macroinvertebrate and fish community structures. Introduced species are often successful in impaired streams (Herbold and Moyle 1986, Wait and Carpenter 2000), though range expansions of nonnative fishes have coincided with improved water quality over the entire New River basin (Messinger and Chambers 2001). 
However, current sizes of native populations may be minimized by previously degraded water quality. The most likely cause of distribution expansion is human movement of fishes throughout the New River system (Easton et al. 1993, Cincotta et al. 1999).

Floods

Characterizing the role of disturbance (i.e. flooding), especially in frequently disrupted lotic systems is needed (Reice et al. 1990). Adequate knowledge of disturbances and recovery of affected systems can aid resource management decision making (Cairns et al. 1971, Hughes et al. 1990, Detenbeck et al. 1992), including, for example, whether or not (or when) to allow systems to naturally recover or be restored by resource managers (Gore et al. 1990, Roghair 2002). Due to their complexity, lotic systems are naturally unstable and are in a constant state of recovery from disturbances (Olmsted and Cloutman 1974, Fisher 1990, Reice et al. 1990).

Disturbances cause systems to deviate from normal conditions (Resh et al. 1988, Niemi et al. 1990). Sousa (1984) defined disturbance as, “a discrete removal of organisms that are subsequently replaced by reproduction of resident survivors or by immigration.” Natural (e.g. droughts and floods) and anthropogenic processes (e.g. pollution, flow regulation, and introduced species) disturb lotic systems, and can kill or remove fishes (Gore et al. 1990). Recovery is the process that returns impacted systems to pre-disturbance levels (Gore et al. 1990, Kelly and Harwell 1990).

Floods and debris flows alter stream habitat, fish assemblages, and fish abundances (Fisher et al. 1982, Dolloff et al. 1994, Matthews 1998). Specifically, flash floods and debris flows remove riparian vegetation, scour streambeds, and drastically alter refuge, foraging, and spawning habitats of fishes. Damage form debris flows (slurries of water, soil, and rocks) exceeds that of floods (Hack and Goodlet 1960, Swanson et al. 1998). Upland streams with high 
gradients are prone to debris flows during high discharge events (Carling 1988). Timing, frequency, and intensity of floods and debris flows influence long-term affects on fish assemblages. Mortality and migration due to frequent and severe floods cause fish abundances to vary over time (Starrett 1951, Seegrist and Gard 1972, Schlosser 1985, Pearsons et al. 1992, Matthews 1998). Tremendous floods and debris flows appear catastrophic and infrequent, but occur regularly on a geologic time scale and are an important component of lotic systems (Roghair 2002).

Stream habitat complexity plays a role in structuring fish assemblages (Schlosser 1982, Poff and Allan 1995, Frenzel and Swanson 1996), and influences the impacts of floods (Collins et al. 1981, Dolloff 1994). Schlosser (1987) characterized streams as hydraulically complex or hydraulically simple. In general, biotic communities of complex streams are more structured and stable than those of simple streams (Pearsons et al. 1992). Flood intensity is less in complex streams and fishes in hydraulically complex streams have lower probabilities of mortality during floods (Pearsons et al. 1992).

The influence of watershed position and stream gradient on flood impacts may be more important to fish assemblages than habitat complexity (Hanson and Waters 1974, Hoopes 1975, Reice et al. 1990). Headwaters and small drainage basins exhibit high variation in flows owing to small size and low storage capacity (Grossman et al. 1990). In general, hydrologic variability reduces the stability of fish assemblages (Starrett 1951, Moyle and Vondracek 1985, Grossman et al. 1990). Harsh environments, such as steep gradients, increase abiotic control of streams (Grossman et al. 1982, Peckarsky 1983). Fishes in high gradient streams are vulnerable to erosive floods (Fausch and Bramblett 1991, Dolloff et al. 1994), in part, due to a lack of refuge areas. Thus, faunas of high gradient streams are controlled, in part, by abiotic factors such as 
extreme floods (Roghair 2002). Fast and turbulent flows scour streambeds; hence benthic fishes may be more susceptible to death by floods than pelagic species. Benthic species (e.g. Cottus bairdi and Rhinichthys cataractae) can be crushed by displaced substrate during floods (Erman et al. 1988). Elwood and Waters (1969) observed high mortality of brook trout from intense flood scouring.

Floods during spawning periods reduce fish populations in small streams (John 1964, Strange et al. 1992). Deposition from floods embeds substrate can eliminate spawning habitats, and smother eggs and larvae (Reice et al. 1990). Conversely, floods can scour streambeds, displacing eggs or larvae. Therefore, fishes that spawn during non-flood seasons increase survival of eggs and larvae. Hanson and Waters (1974) observed that floods in late winter and early spring caused high mortality upon eggs and fry of brook trout (Salvelinus fontinalis). Pearsons et al. (1992) demonstrated that summer spawning species (e.g. cyprinids and catostomids) could be severely impacted by spring and summer floods. Species with extended spawning periods (e.g. Lepomis cyanellus) can maintain viable populations in flood-prone areas (Ross and Baker 1983). Low abundances of adults in flood-impacted streams may increase spawning success (John 1963, Rinne 1975). Spawning success was documented for green sunfish (Lepomis cyanellus), longear sunfish (Lepomis megalotis), and species of Notropis (Harrel 1978, Harvey 1987) immediately following floods

Floods also chronically influence fish populations. Canopy gaps from girdled, broken, or uprooted trees increase sunlight penetration, stream temperature, primary production, macroinvertebrate abundance, and biomass of streams (Lamberti et al. 1991, Murphy et al. 1986, Keith et al. 1998). Food abundance and lower fish densities increase growth rates of flood 
survivors and recolonizers (Sousa 1984, Roghair 2000). However, higher stream temperatures may reduce populations of cold-water species.

Floods after spawning periods increase mortality of juvenile fishes. Juvenile fishes have less probability of surviving major disturbances because of poor swimming ability, habitat specificity, and small size. Minnows and sunfish less than $10 \mathrm{~mm}$ in length are susceptible to

downstream displacement (Harvey 1987). Larger fishes avoid mortality or displacement during flood events through better swimming abilities and use of refuge areas (Fausch and Bramblett 1991).

Historic ecological factors also influence species composition (John 1964, Ross et al. 1985, Matthews 1986, Matthews 1998). Species in unstable streams are normally small, agile, early maturing, and rapid recolonizers with a wide range of physiological tolerances (Fausch and Bramblett 1991). Because floods have impacted fish communities throughout history, species in flood-prone areas lacking these characters have been selected against (Gorman and Karr 1978, Collins et al. 1981, Ross and Baker 1983, Meffe 1984, Moyle and Vondracek 1985). Examples of colonizing fish species are Ictalurus melas, Pimephales sp., Campostoma anomalum, Lepomis cyanellus, and Catostomus commersoni (Grossman et al. 1982, Fausch and Bramblett 1991). Long-term biotic effects of floods should be minimal if fishes are adapted to frequent high discharges (Harrell 1978, Matthews 1998). Meffe and Minckley (1987) suggested that stream fish assemblages are persistent in species present, but vary in abundances following major disturbances.

Drought

Drought can reduce species richness and fish abundances in lotic systems (Wickliff 1945, Starrett 1951, Deacon 1961, Tramer 1977, Matthews 1998). During drought, elevated 
temperatures and low dissolved oxygen levels increase fish mortality (Tramer 1977, Matthews 1998). Fish mortality during drought conditions was increased due to loss of reliable food supply, increased competition for food, decreased habitat availability, and predation (Paloumpis 1958, Tramer 1977, Ladle and Bass 1981, Griswold et al. 1982, Boulton and Stanley 1995).

Fishes in drought-prone areas also tend to possess characteristics that enhance survival in these conditions. Minckley and Barber (1971) found that the Longfin dace (Agosia chrysogaster) seek refuge under algal mats to avoid lethal temperatures of open water. Fishes seek refuge in pools during dry seasons (Wickliff 1945, Paloumpis 1958, Griswold et al. 1982, Capone and Kushlan 1991). Capone and Kushlan (1991) observed that intermediate sized pools with few predators and competitors and complex habitat increased survival of smaller fishes (e.g. cyprinids) during drought. Etheostoma flabellare and Etheostoma spectabile moved downstream to avoid death in shrinking pools of tributaries (Deacon 1961).

Tramer (1977) observed highest mortalities in fishes with subterminal mouths and no air bladders during a drought in Tenmile Creek, Ohio. Oxygen at the surface of stagnant pools was less accessible and energetically expensive to such species. Due to a broader temperature tolerance, Cyprinella lutrensis survived dry-season pools better than Notropis atherinoides (Paloumpis 1958, Matthews and Manes 1979). Capone and Kushlan (1991) observed that species common to dry-season pools (e.g. Lepomis cyanellus) tolerated high temperatures and low oxygen levels.

\section{Recolonization}

Recovery of lotic systems involves spatial and temporal components as well as abiotic and biotic processes (Gore et al. 1990). Fish communities have shown resilience following drought (Larimore 1959, Baylor and Osborne 1993), floods (Roghair 2002), and toxic spills 
(Olmsted and Cloutman 1974). However, recovery of fish communities is difficult to determine due to their unstable nature (Olmsted and Cloutman 1974).

Determining disturbance recovery is important (Kelly and Harwell1990). Niemi et al. (1990) reviewed $>150$ studies of systems (both lotic and lentic) recovering from natural or anthropogenic disturbances. The following endpoints were noted: average size of individuals, density, species richness, total biomass, first time of reappearance, and a return to more stable populations. Recovery endpoints were defined as those values believed to rebound to pre-event levels (Niemi et al. 1990). Other endpoints are relative abundance, physiognomy, and life history strategies of impacted organisms (Fisher 1990). Ensign et al. (1997) showed that species richness and abundance are practical endpoints for mobile species with low abundances or clumped distributions as well as for species with moderate to high abundances and random distributions (at the reach scale only for the latter). However, Ensign et al. (1997) determined that only species richness and abundance were appropriate for species with moderate to high abundances and random distributions at the reach-wide scale.

Though fish assemblages are often resilient, recovery times differ among lotic ecosystems and associated fauna. Niemi et al. (1990) observed that recovery ranged from less than a year to more than fifty-two years. Disturbances that had little impact on the surrounding watershed and instream habitat were correlated with the most rapid recovery. The type, severity and length of disturbances are crucial to the recovery of fish assemblages (Olmsted and Cloutman 1974, Niemi et al. 1990). Longest recovery times often occur in physically-altered stream channels and watersheds (Cairns et al. 1971, Cairns 1990, Sedell et al. 1990, Niemi et al. 1990, Yount and Niemi 1990). Olmsted and Cloutman (1974) showed that fish recolonization began within five days after a pesticide spill. Repopulation was quick in the early stages, but 
gradually decreased in later stages. Matthews (1986) observed drastically altered fish assemblages at badly scoured locations, but fish communities returned to pre-disturbance levels within eight months. Three years after intense flooding in a Virginia stream S. fontinalis density and growth rates exceeded pre-flood levels (Roghair 2002). Other studies have found salmonids to be resilient to disturbances (Lamberti et al. 1991, Swanson et al. 1998). The most resilient systems are likely to be the most frequently disturbed (Reice et al. 1990).

The success of disturbed systems and associated species during recovery depends on several abiotic factors. Intense floods transport silts and boulders. Reice et al. (1990) observed slower recovery when both silt and boulders were disturbed and faster recovery when only sand/silt particles were disturbed. As the number of migration barriers (e.g. cascades, waterfalls) increased, recoveries of distressed systems were slowed (Niemi et al. 1990, Ensign et al. 1997).

Fisher (1990) stated that spatial heterogeneity increases an ecosystem's capacity to recover from disturbances. Hence, it is important that streams are comprised of a variety of habitats. For example, pools are of great importance during floods and droughts because they have higher resistance than riffles and runs. Pools are likely to serve as refuge during disturbances such as floods (Fisher 1990) and droughts (Wickliff 1945, Paloumpis 1958, Griswold et al. 1982, Capone and Kushlan 1991).

Recovery times are influenced by location of potential colonizers (Warner and Fenderson 1962, Olmsted and Cloutman 1974, Tramer 1977, Detenbeck et al. 1992, Niemi et al. 1990, Pearsons et al. 1992). Recovery may be seriously comprimised if the majority of organisms in impacted reaches are displaced or killed (Roghair 2002).

Peckarsky (1983) stated that abiotic factors in harsh lotic environments limit the importance of biotic interactions, and Grossman et al. (1982) found that abiotic interactions are 
important in structuring fish assemblages. Though biotic interactions may have less influence on recovery, their importance should not be underestimated. Floods during spawning periods reduce fish populations in small streams (John 1964, Strange et al. 1992). Deposition from floods embeds substrate and eliminates spawning habitats and eggs/larvae (Reice et al. 1990). Consequently, species requiring specialized spawning habitat might recover slower than fishes with more generalized spawning habitat requirements (Detenbeck et al. 1992). Ensign et al. (1997) observed that fish species with high levels of investment into nesting sites and parental care had more recovery success than those that put forth little effort into parental investment. Recovery times varied among fish reproductive strategies, size at sexual maturity, maximum size and age, and families (Detenbeck et al. 1992).

Fishes in unstable streams (e.g. headwater streams) typically have a wide range of physiological tolerances, are small, agile, and early maturing (Fausch and Bramblett 1991). Consequently, headwater species are very capable of recolonizing disturbed reaches. Cyprinids (minnows) and percids (darters) in headwaters were more capable of surviving environmental extremes such as low and varying dissolved oxygen and $\mathrm{pH}$ levels when compared to mainstem fishes (Matthews and Styron 1980). Minnows, darters, and juveniles have shown higher rates of recovery than larger, older individuals (Olmsted and Cloutman 1974, Niemi et al. 1990, Roghair 2002). Juvenile centrarchids (Olmsted and Cloutman 1974) and salmonids (Roghair 2002) have shown more mobility resulting in quicker recovery rates than adults. 


\section{LITERATURE CITED}

Addair, J. 1944. The fishes of the Kanawha River System in West Virginia and some factors which influence their distribution. Ph.D. dissertation. The Ohio State University, Columbus, Ohio.

Boulton, A. J. and E. H. Stanley. 1995. Hyporheic processes during flooding and drying in a Sonoran Desert stream. Archives of Hydrobiology 134:27-52.

Cairns, J., J. S. Crossman, K. L. Dickson, and E. E. Herricks. 1971. The recovery of damaged streams. Association of Southeastern Biologist Bulletin 18:79-106.

Cairns, J., Jr. 1990. Theoretical basis for predicting rate and pathways of recovery. Environmental Management 14:517-525.

Capone, T. A. and J. A. Kushlan. 1991. Fish community structure in dry-season stream pools. Ecology 72:983-992.

Carling, P. 1988. The concept of dominant discharge applied to two gravelbed streams in relation to channel stability thresholds. Earth Surface Processes and Landforms 13: 355-367.

Cincotta D. A., D.B. Chambers, and T. Messinger. 1999. Recent changes in the distribution of fish species in the New River basin in West Virginia and Virginia. Proceeding of the New River Symposium p.98-106.

Collins, J. P., C. Young, J. Howell, and W. L. Minckley. 1981. Impact of flooding in a Sonoran Desert stream, including elimination of an endangered species (Poeciliopsis o. ocidentalis, poecilidae). The Southwest Naturalist 26:415423.

Cope, E. D. 1868. On the distribution of fresh-water fishes in the Allegheny region of Southwestern Virginia. Journal of the Academy of Natural Sciences of Philadelphia, Series 2, 6, Part 3, Article 5, p. 207-247.

Deacon, J. E. 1961. Fish populations, following a drought, in the Neosho and Marias des Cygnes Rivers of Kansas. University of Kansas Publications of the Museum of Natural History 13:359-427.

Detenback, N. E., P. W. Devore, G. J. Niemi, and A. Lima. 1992. Recovery of temperate-stream fish communities from disturbance: A review of case studies and synthesis of theory. Environmental Management 16:33-53.

Dolloff, C. A., P. A. Flebbe, and M. C. Owen. 1994. Fish habitat and fish populations in a southern Appalachian watershed before and after Hurricane Hugo. Transactions of the American Fisheries Society 123:668-678. 
Easton, R. S., D. J. Orth, and N. M. Burkhead. 1993. The first collection of rudd, Scardinius erythrophthalmus (Cyprinidae), in the New River, West Virginia. Journal of Freshwater Ecology 8:263-264

Easton, R. S. and D. J. Orth. 1994. Fishes of the main channel New River, West Virginia. Virginia Journal of Science 45:265-277.

Elwood, J.W. and T.F. Waters. 1969. Effects of floods on food consumption and production rates of a stream brook trout population. Transactions of the American Fisheries Society 98:253-262.

Ensign, W. E., K. N. Leftwich, P. L. Angermeier, and C. A. Dolloff. 1997. Factors influencing stream fish recovery following a large-scale disturbance. Transactions of the American Fisheries Society 126:895-907.

Erman, D.C., E.D. Andrews, and M. Yoder-Williams. 1988. Effects of winter floods on fishes in the Sierra Nevada. Canadian Journal of Fisheries and Aquatic Sciences 45:2195-2200.

Fausch, K. D. and R. G. Bramblett. 1991. Disturbance and fish communities in intermittent tributaries of a western Great Plains river. Copeia 1991:659-674.

Fisher, S. G., L. J. Gray, N. B. Grimm, and D. E. Busch. 1992. Temporal succession in a desert stream ecosystem following flash flooding. Ecological Monographs 52:93-110.

Fisher, S. G. 1990. Recovery processes in lotic ecosystems: limits of successional theory. Environmental Management 14:725-736.

Frenzel, S. A. and R. B. Swanson. 1996. Relations of fish community composition to environmental variables in streams of central Nebraska, USA. Environmental Management 20:689-705.

Fuller, P. L., L. G. Nico, and J. D. Williams. 1999. Nonindigenous fishes introduced into inland waters of the United States. American Fisheries Society, Special Publication 27. Bethesda, MD.

Goldsborough, E. L. and H. W. Clark. 1908. Fishes of West Virginia. Bulletin of the Bureau of Fisheries 27:31-39.

Gorman O. T. and J. R. Karr. 1978. Habitat structure and stream fish communities. Ecology 59:507-515.

Gore, J. A., J. R. Kelly, and J. D. Yount. 1990. Application of ecological theory to determining recovery potential of disturbed lotic ecosystems: research needs and priorities. Environmental Management 14:755-762. 
Griswold, B. L., C. J. Edwards, and L. C. Woods III. 1982. Recolonization of macroinvertebrates and fish in a channelized stream after a drought. Ohio Journal of Science 82:96-102.

Grossman, G. D., J. F. Dowd, and M. Crawford. 1990. Assemblage stability in stream fishes: A review. Environmental Management 14:661-671.

Grossman, G. D., P. B. Moyle, and J. O. Whitaker, Jr. 1982. Stochasticity in structural and functional characteristics of an Indiana stream fish assemblage: a test of community theory. American Naturalist 120:423-453.

Hack, J. T. and J. C. Goodlet. 1960. Geomorphology of forest ecology of a mountain region in the central Appalachians. U.S. Geological Survey Professional Paper 347.

Hambrick, P. S., C. H. Hocutt, M. T. Masnik and J. H. Wilson. 1973. Additions to the West Virginia icthyofauna, with comments on the distribution of other species. Proceeding of the West Virginia Academy of Science 45:58-60.

Hanson D. L. and T. F. Waters. 1974. Recovery of standing crop and production rate of a brook trout population in a flood-damaged stream. Transactions of the American Fisheries Society 103:431-439.

Harrel, H.L. 1978. Response of the Devil's River (Texas) fish community to flooding. Copeia 1978:60-68.

Harvey, H. L. 1987. Susceptibility of young-of-the-year fishes to downstream displacement by flooding. Transactions of the American Fisheries Society 116:851-855.

Herbold, B. and P. B. Moyle. 1986. Introduced species and vacant niches. American Naturalist 128:751-760.

Hess, L. 1983. Preliminary analysis of the food habits of some New River fishes with emphasis on black fly utilization. W. E. Cox and M. Kegley (eds.), New River Symposium. Glen Jean, WV p. 15-21.

Hocutt, C. H. and P. S. Hambrick. 1973. Hybridization between the darter Percina crassa roanoka and Percina oxyrhynca (Percidae, Etheostomatini), with comments on the distribution of Percina crassa roanoka in the New River. American Midland Naturalist 90:397-405.

Hocutt, C. H., R. F. Denoncourt, and J. R. Stauffer, Jr. 1978. Fishes of the Greenbrier River, West Virginia, with drainage history of the Central Appalachians. Journal of Biogeography 5:59-80.

Hocutt, C. H., R. F. Denoncourt, and J. R. Stauffer, Jr. 1979. Fishes of the Gauley River, 
West Virginia. Brimleyana 1:47-80.

Hocutt, C. H., R. E. Jenkins, and Stauffer, J. R. 1986. Zoogeography of the fishes of the Central Appalachians and Central Atlantic Coastal Plain, in Hocutt, C. H. and Wiley, E. O., eds., The Zoogeography of North American Freshwater Fishes: New York, John Wiley and Sons, p. 161-211.

Hoopes, R. L. 1975. Flooding as the result of Hurricane Agnes, and its effect on native brook trout population in an infertile headwater stream in central Pennsylvania. Transactions of the American Fisheries Society 1:96-99.

Hughes, R. M., T. R. Whittier, C. M. Rohm, and D. P. Larsen. 1990. A regional framework for establishing recovery criteria. Environmental Management 14:673683.

Janssen, R. E. 1953. The Teays River, ancient precursor of the East. Scientific Monthly 77:306-314.

Jenkins, R. E., E. A. Lachner, and F. J. Schwartz. 1972. Fishes of the Central Appalachian Drainages: Their distribution and dispersal. Virginia Polytechnic Institute and State University Research Division Monograph 4:43-117.

Jenkins, R. E. and N. M. Burkhead. 1993. Freshwater Fishes of Virginia. American Fisheries Society. Bethesda, Maryland.

John, K. R. 1963. The effect of torrential rains on the reproductive cycle of Rhinichthys osculus in the Chiricahua Mountains, Arizona. Copeia 1963:286-291.

John, K. R. 1964. Survival of fish in intermittent streams of the Chiricahua Mountains. Arizona Ecology 45:112-119.

Keith, R. M., T. C. Bjorn, W. R. Meehan, N. J. Hetrick, and M. A. Brusven. 1998. Response of juvenile salmonids to riparian and instream cover modifications in small streams flowing through second-growth forests of southeast Alaska. Transactions of the American Fisheries Society 127:889-907.

Kelly, J. R., and M. A. Harwell. 1990. Indicators of ecosystem recovery. Environmental Management 14:527-546.

Ladle, M. and J. A. Bass. 1981. The ecology of a small chalk stream and its responses to drying during drought conditions. Archives of Hydrobiology 90:448-466.

Lamberti, G. A., S. V. Gregory, L. R. Ashkenas, R. C. Wildman, and K. M. S. Moore. 1991. Stream ecosystem recovery following a catastrophic debris flow. Canadian Journal of Fisheries and Aquatic Sciences 48:196-208. 
Larimore, R. W., W. F. Childers, and C. Heckrotte. 1959. Destruction and re-establishment of stream fish and invertebrates affected by drought. Transactions of the American Fisheries Society 88:261-285.

Lessing, Peter. 1997. Geology of the New River Gorge: accessed at URL http://www.wvgs.wvnet.edu/www/geology/geoles01.htm.

Lobb, M. D., III. 1986. Habitat use by fishes of the New River, West Virginia. M.S. thesis. Virginia Polytechnic Institute State University, Blacksburg, Virginia.

Matthews, W. J. and J. Maness. 1979. Critical thermal maxima, oxygen tolerances and success of cyprinid fishes in a southwestern river. Southwest Naturalist 24:374-377.

Matthews, W. J. 1986. Fish faunal structure in an Ozark stream: stability, persistence, and a catastrophic flood. Copeia 1986:388-397.

Matthews, W. J. 1998. Patterns in Freshwater Fish Ecology. Kluwer Academic Publishers. Norwell, Massachusetts.

Matthews, W. J. and J. T. Styron. 1980. Tolerance of headwater vs. mainstream fishes for abrupt physiochemical changes. American Midland Naturalist 103:149-158.

McKeown, P. E., C. H. Hocutt, R. P. Morgan, and J. H. Howard. 1984. An electrophoretic analysis of the Etheostoma variatum complex (Percidae: Etheostomatini), with associated zoogeographic considerations. Environmental Biology of Fishes 11:8595.

Meffe, G. K. 1984. Effects of abiotic disturbances on coexistance of predator-prey fish species. Ecology 65:1525-1534.

Meffe, G.K. and W. L. Minckley. 1987. Persistence and stability of fish and invertebrate assemblages in a repeatedly disturbed Sonoran Desert stream. American Midland Naturalist 117:177-191.

Messinger, T. and C.A. Hughes. 2000. Environmental setting and its relations to water quality in the Kanawha River Basin. U.S. Geological Water-Resources Investigations Report 00-4020.

Messinger, T. and D.B. Chambers. 2001. Fish communities and their relation to environmental factors in the Kanawha River Basin, West Virginia, Virginia, and North Carolina, 1997-98. U.S. Geological Survey Water-Resource Investigation Report 014048.

Minckley, W. L. and W. E. Barber. 1971. Some aspects of biology of the Longfin dace, a cyprinid fish characteristic of streams in the Sonoran Desert. Southwest Naturalist 15:459-464. 
Moyle, P. B. and B. Vondracek. 1985. Persistence and structure of the fish assemblage in a small California stream. Ecology 66:1-13.

Moyle, P. B. and T. Light. 1996. Fish invasions in California: Do abiotic factors determine success? Ecology 77:1666-1670.

Murphy, M. L., J. H. Heifetz, S. W. Johnson, K. V. Koski, and J. F. Thedinga. 1986. Effects of clear-cut logging with and without buffer strips of juvenile salmonids in Alaskan streams. Canadian Journal of Fisheries and Aquatic Sciences 43:1521-1533.

National Oceanic Atmospheric Administration (NOAA). Extreme Weather and Climate Events. URL http://www.ncdc.noaa.gov/oa/climate/severeweather/extremes.html.

Neves, R. J. 1983. Distributional history of the fish and mussel fauna in the Kanawha River drainage. Proceedings of the New River Symposium 47-67.

Niemi, G. J., P. DeVore, N. Detenbeck, D. Taylor, A. Lima, J. Pastor, J. D. Yount, R. J. Naiman. 1990. Overview of case studies on recovery of aquatic systems from disturbance. Environmental Management 14:571-587.

Olmsted, L. L. and D. G. Cloutman. 1974. Repopulation after a fish kill in Mud Creek, Washington County, Arkansas following a pesticide pollution. Transactions of the American Fisheries Society 1:79-87.

Paloumpis, A. A. 1958. Response of some minnows to flood and drought conditions in an intermittent stream. Iowa State College Journal of Science 32:547-561.

Paybins, K.S., T. Messinger, J.H. Eychaner, D.B. Chambers, and M.D. Kozar. Water Quality in the Kanawha-New River Basin, West Virginia, Virginia, and North Carolina, 1996-98. U.S. Geological Survey Circular 1204.

Pearsons, T. N., H. W, Li, and G. A. Lamberti. 1992. Influence of habitat complexity on resistance to flooding and resilience of stream fish assemblages. Transactions of the American Fisheries Society 121:427-436.

Peckarsky, B. L. 1983. Biotic interactions or abiotic limitations? A model of lotic community structure. In T. D. Fontaine and S. M. Bartell (eds.), Dynamics of lotic ecosystems. Ann Arbor Science, Ann Arbor, Michigan, p. 303-323.

Poff, L. N. and J.D. Allan. 1995. Functional organization of stream fish assemblages in relation to hydrological variability. Ecology 76:606-627.

Reice, S. R., R. C. Wissmar, and R. J. Naiman. 1990. Disturbance regimes, resilience, and recovery of animal communities and habitats in lotic ecosystems. Environmental Management 14(5):647-659. 
Resh, V. H., A. V. Brown, A. P. Covich, M. E. Gurtz, H. W. Li, G. W. Minshall, S. R. Reice, A. L. Sheldon, J. B. Wallace, and R. Wissmar. 1988. The role of disturbance in stream ecology. Journal of the North American Benthological Society 7:433-455.

Rinne, J. N. 1975. Changes in minnow populations in a small desert stream resulting from naturally and artificially induced factors. The Southwest Naturalist 20:185195.

Roghair, C. N., C. A. Dolloff, and M. K. Underwood. 2002. Response of a brook trout population and instream habitat to a catastrophic flood and debris flow. Transactions of the American Fisheries Society 131:718-730.

Roghair, C. N. 2000. Recovery from and effects of a catastrophic flood and debris flow on the brook trout (Salvelinus fontinalis) population and instream habitat of the Staunton River, Shenandoah National Park, Virginia. Masters Thesis, Virginia Polytechnic Institute and State University, Blacksburg, Virginia.

Ross, R. D. 1959. A key to fishes of the Shenandoah River system of Virginia. Virginia Agricultural Experiment Station Technical Bulletin 142.

Ross, R. D. and B. D. Perkins. 1959. Drainage evolution and distribution problems of the fishes of the New (upper Kanawha) River system in Virginia, part 3: records of fishes of the New River. Virginia Agricultural Experiment Station Technical Bulletin 145.

Ross, R. D. and J. E. Carico. 1963. Records and distribution problems of fishes of the North, Middle, and South forks of the Holston River, Virginia. Virginia Agricultural Experiment Station Technical Bulletin 161.

Ross, R. D. 1969. Drainage evolution and fish distribution problems in the southern Appalachians of Virginia, in The Distributional History of the Biota of the Southern Appalachians. Part I: Invertebrates (ed. P. C. Holt). Research Division Monograph No. 1, Virginia Polytechnic Institute and State University, Blacksburg 277-292.

Ross, S. T. and J. A. Baker. 1983. The response of fishes to periodic spring floods in southeastern stream. American Midland Naturalist 109:1-14.

Ross, S. T., W. J. Matthews, and A. A. Echelle. 1985. Persistence of stream fish assemblages: Effects of environmental change. The American Naturalist 126:24-40.

Ross, S. T. 1991. Mechanisms structuring stream fish assemblages: Are there lessons to be learned from introduced species? Environmental Biology of Fishes 30:359-368.

Schlosser, I. J. 1982. Fish community structure and function along two habitat gradients in a headwater stream. Ecological Monographs 52:395-414. 
Schlosser, I. J. 1985. Flow regime, juvenile abundance, and the assemblage structure of stream fishes. Ecology 66:1484-1490.

Schlosser, I. J. 1987. A conceptual framework for fish communities in small, warm water streams. In Community and evolutionary ecology of North American Stream Fishes. W. J. Mathews and D. C. Heins (eds.). University of Oklahoma Press. Norman, Oklahoma p. 17-24.

Sedell, J., R. Hauer, C. P. Hawkins, and J. Stamford. 1990. The role of refugia in recovery from disturbance: modern fragmented and disconnected river systems. Environmental Management 17:711-724.

Seegrist, D. W. and R. Gard. 1972. Effects of floods on trout in Sagehen Creek, California. Transactions of the American Fisheries Society 101:478-482.

Sousa, W. P. 1984. The role of disturbance in stream natural communities. Annual Review of Ecology and Systematics 15:353-391.

Starrett, W.C. 1951. Some factors affecting the abundance of minnows in the Des Moines River, Iowa. Ecology 32:13-27.

Stauffer, J. R., J. M. Boltz, and L. R. White. 1995. The Fishes of West Virginia. Academy of Natural Sciences. Philadelphia, Pennsylvania.

Strange, E. M., P. B. Moyle, and T. C. Foin. 1992. Interactions between stochastic and deterministic processes in stream fish community assembly. Environmental Biology of Fishes 36:1-15.

Swanson, F. J., S. L. Johnson, S. V. Gregory, and S. A. Acker. 1998. Flood disturbance in a forested mountain landscape. BioScience 48:681-689.

Swift, Ellsworth. 2000. Geology of the New River: Accessed at URL http://www.nps.gov/neri/geology.htm

Tramer, E. J. 1977. Catastrophic mortality of stream fishes trapped in shrinking pools. American Midland Naturalist 97:469-478.

Ver Steeg, K. 1946. The Teays River. Ohio Journal of Science 46:297-307.

Waite, J. R. and Carpenter, K. D. 2000. Associations among fish assemblage structure and environmental variables in Williamette Basin stream, Oregon. Transactions of the American Fisheries Society 129:754-770.

Warner, K. and O. C. Fenderson. 1962. Effects of DDT spraying for forest insects on Maine trout streams. Journal of Wildlife Management 26: 86-93. 
Wickliff, E. L. 1945. Some effects of droughts and floods on stream fish. Ohio Division of Conservation and Natural Resources 17:23-31.

Wilson, L. and J. M. Purvis. 2000. Water quality monitoring program 1994-1997, New River Gorge National River, Bluestone National Scenic River, and Gauley River National Recreation Area. National Park Service, Glen Jean, West Virginia.

Wood, D. M. 1990. New River Gorge National River water quality study 1989 . West Virginia Division of Natural Resources. Charleston, WV.

Yount, J. D. and G. J. Niemi. 1990. Recovery of lotic communities and ecosystems from disturbance - a narrative review of case studies. Environmental Management 14:547570. 


\title{
Chapter 2: Ichthyofauna of the New River Gorge National River, West Virginia
}

\begin{abstract}
\end{abstract}
An understanding of current and historic fish distributions within the New River Gorge National River (NRGNR) is a critical management need for the National Park Service. What is most striking about the New River basin's fish fauna is that nearly one-half of the fish species are nonnative. Previous surveys of the NRGNR fish fauna focused largely on the New River mainstem and larger tributaries, with few efforts on small tributaries within the NRGNR. During 2001-2003 we conducted 84 fish surveys of 36 tributaries in NRGNR to document current distributions and fill information gaps on range expansions of nonnative species. This data combined with previous fish distribution data (as far back as 1928) revealed that 62 fish species and 3 hybrids within or near NRGNR boundaries have been collected. Based on species origins reported in the literature, at least 31 (50\%) of these fishes are nonnative. This synthesis of fish distribution data provides managers of the NRGNR with abundance and distribution information concerning native and nonnative fish species, and will be useful for decisions on management of aquatic resources within NRGNR. We recommend long term monitoring programs within NRGNR to document distributional expansion of recently introduced nonnative fishes and status of native fish species. 


\section{INTRODUCTION}

The New River, a tributary of the Kanawha River, flows northward from headwaters in North Carolina and ends at Kanawha Falls, West Virginia (near the confluence with Gauley River). The New River watershed, approximately 17,918 km², includes parts of the Blue Ridge, Valley and Ridge, and Appalachian Plateau (Stauffer et al. 1995). Nine large river basins, several with relatively large fish faunas, surround the New River. Claytor, Bluestone, and Hawks Nest are three major impoundments on the New River and four smaller dams occur upstream of Claytor Reservoir. An 85 km section of the New River in southern West Virginia (below Bluestone Dam) is designated as the New River Gorge National River (NRGNR) and has been administered by the National Park Service since 1978.

Several researchers have studied the fish fauna of the New River within West Virginia, although earliest records and documentation of the native fauna are from Virginia waters (Cope 1868). Goldsborough and Clarke (1908) and Addair (1944) documented fish distributions within the West Virginia portion of the New River. These early collections were supplemented by later accounts by Jenkins et al. (1972), Hocutt et al. (1978, 1979), Hess (1983), Lobb (1986), Neves (1983), Easton et al. (1993), Jenkins and Burkhead (1993), Easton and Orth (1994), Stauffer et al (1995), Cincotta et al. (1999), Messinger and Hughes (2000), Paybins et al. (2000), Messinger and Chambers (2001). The West Virginia Division of Natural Resources (WVDNR) has collected from the New River since the 1950’s. The National Park Service (NPS) in Glen Jean, West Virginia has collected from four sites since 1979. Most collections have occurred on the New River mainstem or in large tributaries.

Jenkins and Burkhead (1993) list 89 fishes from the New River system (47 native and 42 nonnative), including eight endemics. This is the largest number and proportion of nonnative to 
native species in the eastern and central North American drainages (Jenkins and Burkhead 1994). The New River, with lower species richness than neighboring drainages, has the lowest ratio of native species to drainage area of the 26 eastern major river systems. Stocking programs (and possibly bait-bucket transfers) prior to comprehensive fish surveys in the New River (Cincotta et al. 1999) complicate the understanding of native and nonnative species status (Hocutt et al. 1986). Based on early surveys by Cope (1868), only 4 large piscivorous fishes (Anguilla rostrata, American eel; Ictalurus punctatus, channel catfish; Pylodictis olivaris, flathead catfish; and Lepomis cyanellus, green sunfish) existed in the New River system before introductions (Hocutt et al. 1986). Salvelinus fontinalis (brook trout) was also in the drainage but was inadvertently left off the Hocutt et al. (1986) list (R. E. Jenkins pers. comm.).

The New River’s patchily distributed and depauperate fish fauna (47 native species) and high rate of endemism (eight species) are influenced by drainage history. Barriers from geologic processes (waterfalls, rapids, and cascades) have detained dispersal of fishes and isolated populations (Neves 1983, McKeown et al. 1984, Jenkins and Burkhead 1994, Messinger and Chambers 2001). Fish dispersal and population isolation in the New River system were also influenced by glacial and interglacial periods of the Pleistocene (Jenkins et al. 1972, Neves 1983, McKeown et al. 1984). Stream piracy has influenced the movement of fishes into and out of the New River system (Neves 1983, Jenkins et al. 1972, Hocutt et al. 1986, Jenkins and Burkhead 1992), and may partially explain the depauperate fauna (Hocutt et al. 1986).

The New River Gorge National River was established in 1978 and placed under the direction of the Department of the Interior, National Park Service. Due to the lack of historical data within NRGNR tributaries, the National Park Service needs information on fish distributions for inventory and monitoring purposes. The goal of this study was to provide NPS 
with an accurate database and a current document of recent and previous fish surveys within NRGNR. To meet this goal, objectives were to:

1. Document the distribution of fishes in perennial tributaries within or near the NRGNR

2. Compile historic and recent fish distribution records from within or near the NRGNR.

\section{METHODS}

Study area

The study was conducted within the boundaries of the NRGNR in southern West Virginia (Figure 1). Park boundaries begin just downstream of Hinton and end slightly downstream of Fayette Station. The NRGNR is approximately $85 \mathrm{~km}$ long and encompasses 70,000 acres and 77 tributaries. In many places, the gorge rim rises 305 meters above the New River and maximum height is approximately 488 meters. Tributaries typically contained steep gradients, cascades, and waterfalls, with cobble, boulder, or bedrock substrates.

Fish distribution records from within or near NRGNR from over 200 collection sites dating back to 1928 were compiled (Table 1, Figure 2). Thirty-six sites on 26 tributaries within NRGNR during fall 2001 were sampled. Twelve of the 36 sites were re-sampled on three occasions in 2002 (spring, summer, and fall) and once during the spring of 2003 (Table 1). Therefore, a total of 84 collections from 2001 to 2003 were conducted. Primarily, streams were sampled near tributary mouths, but some upstream sites were also sampled.

Fish Collections

A two or three-pass removal method with a DC backpack electrofishing unit at sites on smaller tributaries, whereas a single pass was made on larger tributaries. Fish collections began at the lower end of the sampling reach, and lengths of study sites were approximately 40 times 
the mean wetted width with a minimum of 150 meters. Pools, runs, and riffles were included in all sampling reaches. In the field, species were identified and measured for total length. Species abundances were recorded for each electrofishing pass. After completing measurements, fishes were released to the approximate capture area, except those preserved for voucher specimens. Specimens, fixed in 10\% formalin and preserved in 70\% ethanol, were catalogued and shelved at the West Virginia University fish museum.

\section{RESULTS}

Between 1928 and 2003, eleven families including 60 species, and two hybrids (S. fontinalis x S. trutta and N. rubellus x L. albeolus), were collected within or near the NRGNR boundaries. At least 31 (50\%) of the 62 species are nonnative (Jenkins and Burkhead 1994). The following species accounts summarize fish distributions within or near park boundaries of the NRGNR, where site locations are described (Table 1) and mapped (Figures 2 - 61). Numbers listed with each species (under Species accounts) correspond to sites in Table 1. Origin for each species is taken primarily from Jenkins and Burkhead (1993).

Species accounts

\section{Clupeidae}

Dorosoma cepedianum (LeSueur), gizzard shad. 72, 73, 101, 175. Introduced. Figure 3

\section{Esocidae}

Esox masquinongy (Mitchell), muskellunge. 168, 174, 175, 192 . Introduced. Figure 4

\section{Cyprinidae}

Campostoma anomalum (Rafinesque), central stoneroller. 3, 4, 9, 10, 16, 18, 23, 33, 35, 37, 43, 55, 58, 59, 60, 61, 70, 71, 73, 76, 77, 79, 81, 82, 86, 87, 91, 92, 96, 98, 100, 101, 103, 104, 106, $107,108,110,111,112,115,117,120,121,122,125,126,127,128,130,132,134,147,148$, 
152, 153, 154, 155, 156, 159, 163, 164, 166, 167, 169, 170, 171, 172, 173, 176, 177, 178, 179, 182, 184, 185, 186, 187, 188, 189, 191, 194, 195, 196, 197, 201, 204, 205, 206. Native. Figure 5

Clinostomus funduloides (Girard), rosyside dace. 12, 13, 14, 19, 25, 26, 29, 46, 48, 57, 70, 104, 125, 140, 143, 151, 159, 164, 172, 187, 197, 198, 199, 200. Native. Figure 6

Cyprinella galactura (Cope), whitetail shiner. 55, 61, 70, 72, 73, 79, 86, 91, 100, 101, 104, 107, 117, 120, 126, 152, 153, 159, 177, 178, 179, 186, 191. Introduced probably. Figure 7

Cyprinella spiloptera (Cope), spotfin shiner. 6, 8, 20, 43, 62, 70, 72, 73, 74, 79, 80, 83, 84, 85, 86, 91, 99, 100, 101, 102, 105, 126, 153, 154, 167, 170, 171, 173, 177, 179, 180, 182, 184, 190, 191, 194, 195, 201. Native. Figure 8

Cyprinus carpio (Linnaeus), common carp. 7, 43, 68, 154, 174, 179, 180, 194. Introduced.

Figure 9

Ericymba buccata (Cope), silverjaw minnow. 3, 4, 8, 16, 20. Native. Figure 10

Erimystax dissimilis (Kirtland), streamline chub. 105. Native. Figure 11

Exoglossum laurae (Hubbs) tonguetied minnow. 68, 175, 188. Native. Figure 12

Luxilus albeolus (Jordan), white shiner. 4, 59, 60, 61, 70, 71, 73, 81, 82, 88, 90, 91, 101, 104, 106, 107, 126, 129, 149, 153, 154, 156, 163, 167, 170, 171, 173, 177, 179, 184, 185, 186, 191, 194. Native but possibly introduced. Figure 13

Luxilus chrysocephalus (Rafinesque), striped shiner. 3, 4, 6, 58, 62, 73, 101, 176, 179, 182, 194, 195. Native but possibly introduced. Figure 14

Nocomis platyrhynchus (Lachner and Jenkins), bigmouth chub. 3, 4, 33, 61, 64, 70, 71, 72, 73, 74, 82, 84, 85, 86, 88, 90, 91, 100, 101, 102, 104, 107, 120, 121, 122, 126, 148, 152, 153, 163, 167, 169, 170, 171, 173, 174, 177, 178, 179, 180, 182, 191, 194. Endemic. Figure 15 
Notemigonus crysoleucas (Mitchell), golden shiner. 62, 88, 171, 179, 192, 194. Introduced.

Figure 16

Notropis hudsonius (Clinton), spottail shiner. 4, 71, 72, 73, 84, 85, 86, 91, 100, 101, 102, 154, 159, 178, 179, 180, 184, 191. Introduced probably. Figure 17

Notropis photogenis (Cope), silver shiner. 4, 59, 62, 72, 73, 74, 91, 101, 102, 128, 154, 156, 171, 179, 180, 182, 185, 194, 201, 204. Native. Figure 18

Notropis rubellus (Agassiz), rosyface shiner. 3, 4, 43, 59, 60, 61, 72, 73, 74, 82, 84, 90, 91, 99, $100,101,102,126,128,148,152,153,156,159,171,173,176,177,178,179,180,184,191$, 195, 201, 204. Native. Figure 19

Notropis scabriceps (Cope), New River shiner. 73, 101, 179, 190, 201, 204. Endemic. Figure 20

Notropis stramineus (Cope), sand shiner. 86, 204. Native. Figure 21

Notropis telescopus (Cope), telescope shiner. 3, 4, 55, 59, 60, 61, 70, 71, 72, 73, 74, 79, 81, 82, 85, 86, 87, 90, 91, 100, 101, 102, 104, 107, 117, 122, 126, 127, 128, 148, 152, 153, 154, 155, 156, 159, 167, 170, 171, 173, 177, 178, 179, 180, 184, 185, 186, 191, 195. Introduced probably. Figure 22

Notropis volucellus (Cope), mimic shiner. 3, 4, 8, 20, 60, 61, 72, 73, 74, 85, 86, 90, 91, 99, 100, 101, 102, 148, 149, 167, 171, 177, 179, 180, 184, 186, 190, 194, 195, 201, 204. Native. Figure 23

Phoxinus oreas (Cope), mountain redbelly dace. 37, 159, 178, 191. Native. Figure 24

Pimephales notatus (Rafinesque), bluntnose minnow. 3, 4, 8, 16, 19, 24, 28, 43, 60, 61, 62, 71, 83, 84, 86, 88, 91, 92, 96, 99, 100, 101, 102, 122, 130, 132, 148, 154, 156, 166, 167, 171, 177, 179, 180, 182, 184, 186, 190, 192, 194, 195, 205, 206. Native but possibly introduced. Figure 25 
Pimephales promelas (Rafinesque), fathead minnow. 70. Introduced. Figure 26

Rhinichthys atratulus (Hermann), blacknose dace. 9, 10, 11, 12, 13, 14, 15, 16, 19, 21, 24, 25, 26, 28, 29, 30, 31, 34, 36, 37, 39, 40, 42, 45, 46, 47, 48, 49, 50, 52, 56, 57, 64, 70, 76, 77, 79, 81, 87, 88, 91, 92, 95, 96, 97, 98, 99, 103, 104, 108, 109, 110, 111, 112, 113, 115, 116, 117, 118 , $120,121,125,130,131,132,133,134,135,147,139,140,143,145,146,147,148,149,153$,

155, 159, 164, 166, 171, 172, 184, 185, 186, 187, 188, 190, 191, 193, 196, 197, 199, 200, 201, 203, 204, 205, 206, 207. Native. Figure 27

Rhinichthys cataractae (Valenciennes), longnose dace. 3, 4, 8, 55, 59, 60, 61, 70, 71, 72, 73, 74, 78, 81, 82, 86, 91, 100, 101, 102, 103, 106, 109, 110, 111, 112, 115, 122, 126, 128, 131, 134, 135, 137, 139, 152, 153, 156, 167, 173, 179, 180, 195, 204. Native. Figure 28

Semotilus atromaculatus (Mitchell), creek chub. 1, 2, 4, 9, 10, 12,13, 14, 15, 16, 17, 19, 20, 21, $24,25,26,28,19,30,31,34,35,37,38,39,40,41,42,43,45,46,48,51,53,57,59,64,67,70$, 73, 75, 77, 79, 83, 84, 87, 88, 89, 91, 92, 93, 95, 96, 98, 103, 104, 107, 108, 109, 110, 111, 112, $114,115,116,117,118,119,120,121,125,126,128,130,132,133,135,137,139,140,143$, $145,146,147,151,152,153,155,157,159,161,162,164,166,172,176,180,185,186,187$, 188, 189, 190, 191, 193, 194, 196, 197, 198, 199, 200, 202, 203, 204, 205, 206, 207, 210. Native. Figure 29

\section{Catostomidae}

Catostomus commersoni (Lacepede), white sucker. 4, 5, 11, 12, 15, 16, 19, 21, 22, 24, 25, 26, 30, 34, 37, 48, 54, 57, 58, 59, 62, 64, 70, 87, 88, 92, 95, 96, 98, 108, 109, 111, 112, 113, 121, 130, 132, 143, 145, 146, 148, 157, 159, 162, 166, 172, 186, 187, 189, 191, 193, 196, 199, 200, 204, 205, 206, 207. Native. Figure 30 
Hypentelium nigricans (LeSueur), northern hogsucker. 1, 2, 3, 4, 6, 7, 9, 12, 14, 15, 16, 18, 19, $23,24,25,26,28,29,30,31,33,35,37,39,40,43,46,55,59,60,61,62,66,70,71,72,73,74$, 75, 82, 84, 85, 86, 90, 91, 93, 95, 100, 101, 102, 104, 105, 107, 117, 120, 121, 122, 126, 134, 152, 153, 154, 156, 159, 163, 167, 171, 173, 174, 175, 178, 179, 180, 182, 184, 185, 190, 191, 192, 194, 201, 205, 210. Native. Figure 31

\section{Ictaluridae}

Ameiurus natalis, (LeSueur), yellow bullhead. 85, 86, 100, 101, 167, 171, 173, 178, 179, 182, 191. Introduced but possibly native. Figure 32

Ictalurus punctatus (Rafinesque), channel catfish. 3, 7, 8, 32, 43, 83, 85, 86, 93, 100, 101, 105, 174, 178, 179, 182, 183, 192, 194. Native. Figure 33

Pylodictis olivaris (Rafinesque), flathead catfish. 6, 8, 33, 43, 72, 73, 74, 80, 83, 85, 86, 90, 91, $100,101,102,105,114,126,152,154,167,169,170,173,174,175,178,179,180,181,182$, 183, 184, 194. Native. Figure 34

\section{Atherinidae}

Labidesthes sicculus (Cope), brook silverside. 43, 74, 102, 154, 174, 175, 180, 182. Introduced.

Figure 35

\section{Cottidae}

Cottus bairdi (Girard), mottled sculpin. 12, 14, 15, 26, 30, 122, 140, 143, 145, 146, 162. Native. Figure 36

\section{Moronidae}

Morone chrysops (Rafinesque), white bass. 7, 43, 182, 192, 194. Introduced. Figure 37

\section{Salmonidae}

Oncorhynchus mykiss (Walbaum), rainbow trout. 13, 40, 46, 64, 78, 87, 110, 113, 130, 136, 137, 
138, 139. Introduced. Figure 38

Salmo trutta (Linnaeus), brown trout. 24, 29, 40, 46, 47, 48, 49, 55, 70, 76, 77, 79, 82, 87, 92, 95, $96,104,107,110,111,112,118,121,126,129,131,133,135,136,137,138,139,140,141$, 143, 144, 146, 149, 152, 157, 158, 160, 172, 187, 197, 198, 203. Introduced. Figure 39

Salvelinus fontinalis (Mitchell), brook trout. 70, 87, 104, 111, 117, 121, 123, 124, 201. Native.

Figure 40

\section{Centrarchidae}

Ambloplites rupestris (Rafinesque), rockbass. 4, 6, 7, 8, 9, 16, 18, 19, 22, 23, 24, 29, 37, 43, 54, 55, 60, 61, 62, 64, 70, 71, 72, 73, 74, 82, 85, 86, 90, 91, 92, 96, 100, 101, 102, 105, 107, 117, 121, 122, 126, 132, 151, 152, 153, 154, 155, 157, 163, 165, 167, 169, 170, 171, 173, 174, 175, 177, 178, 179, 180, 181, 182, 183, 184, 185, 186, 189, 190, 191, 192, 193, 194, 195, 206.

Introduced. Figure 41

Lepomis auritus (Linnaeus), redbreast sunfish. 7, 72, 73, 74, 85, 86, 91, 100, 101, 102, 162, 175, 178, 179, 180, 182, 183, 192, 194. Introduced. Figure 42

Lepomis cyanellus Rafinesque, green sunfish. 6, 16, 20, 32, 48, 58, 61, 62, 70, 74, 75, 76, 79, 82, 84, 85, 86, 87, 91, 92, 96, 97, 100, 101, 104, 107, 111, 112, 114, 117, 120, 126, 131, 152, 153, 157, 159, 172, 178, 179, 186, 191, 197. Native. Figure 43

Lepomis gibbosus (Linnaeus), pumpkinseed. 6, 43, 55, 74, 79, 86, 100, 101, 117, 146, 159, 171, 179, 180, 191, 192, 194. Introduced. Figure 44

Lepomis macrochirus (Rafinesque), bluegill. 6, 8, 16, 19, 22, 28, 30, 43, 54, 60, 68, 70, 72, 73, 74, 76, 85, 86, 91, 99, 100, 101, 102, 107, 109, 117, 143, 147, 150, 152, 154, 162, 171, 174, 175, 177, 178, 179, 180, 182, 183, 184, 185, 190, 191, 192, 194, 195, 201. Introduced. Figure 45 Lepomis megalotis (Rafinesque), longear sunfish. 73, 85, 86, 100, 101, 102, 174, 175, 177, 179, 
194. Introduced. Figure 46

Micropterus dolomieu (Lacepede), smallmouth bass. 2, 3, 4, 6, 7, 8, 9, 18, 23, 33, 43, 54, 55, 58, $59,60,61,62,63,64,66,68,70,71,72,73,74,79,82,83,84,85,86,87,88,91,93,99,100$, 101, 102, 104, 105, 107, 111, 114, 117, 120, 121, 122, 125, 126, 148, 151, 152, 154, 155, 156, 159, 163, 167, 169, 170, 171, 173, 174, 175, 177, 178, 179, 180, 181, 182, 183, 184, 185, 186, 190, 191, 192, 194, 201, 210. Introduced. Figure 47

Micropterus punctulatus (Refinesque), spotted bass. 3, 4, 6, 8, 20, 43, 46, 58, 60, 62, 72, 73, 74, 83, 84, 85, 86, 100, 101, 102, 149, 150, 154, 167, 171, 175, 178, 179, 180, 181, 182, 183, 184, 190, 191, 192, 194, 195. Introduced. Figure 48

Micropterus salmoides (Lacepede), largemouth bass. 6, 8, 35, 57, 68, 73, 100, 101, 157, 174, 176, 177, 178, 180, 181, 182, 183, 190, 194, 196. Introduced. Figure 49

Pomoxis annularis Rafinesque, white crappie. 16, 43, 85, 86, 102, 154, 171, 174, 180, 191, 194. Introduced. Figure 50

Pomoxis nigromaculatus (LeSueur), black crappie. 8, 83, 85, 101, 154, 171, 184. Introduced.

Figure 51

\section{Percidae}

Etheostoma blennioides (Rafinesque), greenside darter. 3, 4, 23, 59, 60, 72, 73, 74, 82, 85, 86, 90, 91, 99, 100, 101, 102, 105, 121, 122, 126, 128, 152, 153, 159, 167, 169, 170, 171, 173, 176 , 177, 178, 179, 180, 182, 184, 186, 189, 190, 194, 195, 201, 204, 205, 206. Native. Figure 52 Etheostoma caeruleum (Storer), rainbow darter. 3, 60, 61, 70, 72, 73, 74, 81, 82, 85, 86, 87, 91, $100,101,102,104,106,107,114,117,119,120,121,122,125,126,127,128,148,152,153$, 155, 156, 159, 167, 168, 170, 171, 173, 177, 178, 179, 180, 184, 185, 186, 191. Introduced.

Figure 53 
Etheostoma flabellare (Rafinesque), fantail darter. 2, 14, 15, 21, 23, 24, 25, 26, 28, 29, 64, 87, 88, 92, 95, 96, 99, 101, 106, 108, 109, 110, 111, 112, 113, 115, 126, 131, 132, 135, 137, 147, 148, 149, 162, 172, 187, 188, 189, 193, 197, 201, 204, 205, 206. Native. Figure 54

Etheostoma nigrum (Rafinesque), johnny darter. 8, 56. Native. Figure 55

Etheostoma variatum Kirtland, variegate darter. 61, 73, 91, 101, 107, 120, 121, 122, 126, 127, 152, 153, 159, 177, 179, 186. Introduced. Figure 56

Percina caprodes (Rafinesque), logperch. 3, 4, 7, 55, 72, 73, 74, 85, 86, 91, 100, 101, 102, 174, 175, 180. Native. Figure 57

Percina maculata (Girard), blackside darter. 59, 60, 166, 196, 199, 200. Introduced but possibly native. Figure 58

Percina oxyrhynchus (Hubbs and Raney), sharpnose darter. 3, 8, 33, 43, 59, 60, 72, 73, 74, 82, 85, 86, 90, 91, 100, 101, 102, 105, 122, 126, 129, 169, 170, 180, 182, 184, 190, 194. Native.

Figure 59

Percina roanoka (Jordan and Jenkins), Roanoke darter. 59, 60, 61, 71, 72, 73, 74, 85, 86, 90, 91, $100,101,102,126,127,128,152,153,156,167,169,170,171,173,178,179,180,184,185$, 186. Introduced probably. Figure 60

Perca flavescens (Mitchell), yellow perch. 43, 154, 179, 182, 192, 194. Introduced. Figure 61

Sander vitreus (Mitchell), walleye. 6, 7, 32, 43, 83, 105, 183, 192. Introduced. Figure 62 Scardinius erythrophthalmus (Linnaeus), European rudd. 179. Introduced. Figure 63

\section{DISCUSSION}

Fish introductions are common in aquatic systems throughout the United States (Fuller et al. 1999) and the NRGNR is no exception. Sixty-two species have been collected from within or near the NRGNR. At least 31 (50\%) of the 62 species within NRGNR are nonnative (Jenkins 
and Burkhead 1994), exceeding the estimate of Easton and Orth (1994) between Bluestone Dam and Fayette Station. During recent study, three nonnative species to the New River checklist (i.e., drainages above Kanawha Falls) were added; Phoxinus erthrogaster (southern redbelly dace), Etheostoma variatum (variegate darter), and Percina maculata (blackside darter). The overall high number of nonnatives within the New River drainage has multiple explanations. Several game and forage fishes were introduced by state agencies and citizens (Jenkins and Burkhead 1994, Easton and Orth 1994, Cincotta et al. 1999). Many of these introductions date back to the late 1800s. Bait-bucket introduction is a likely source of most nonnative nongame populations (Cincotta et al. 1999), including species not commonly thought of as baitfish (e.g. darters).

Streams with low numbers of native fishes (Hocutt and Hambrick 1973), occur in close proximity to speciose drainages, and have high impairment (Herbold and Moyle 1986, Wait and Carpenter 2000) often support nonnative species. The New River, naturally depauperate of native fishes, is surrounded by nine large river basins (all potential sources of nonnatives). The New River is impaired by coal mining, domestic waste, logging, agriculture, industrial activities, urbanization, and oil/gas extraction (Addair 1944, Messinger and Hughes 2000, Wilson and Purvis 2000). Range expansions of nonnatives within New River, however, have coincided with water quality improvements throughout the basin (Messinger and Chambers 2001), although current sizes of native populations may be minimized by earlier water quality impairment. Extirpation and population declines of native species

Comparison of historic and current data on species abundance and presence/absence provides insight into faunal change, but is often confounded by incomparable collection methods or sampling conditions. Herein, faunal change based on available information is discussed. 
Populations within or near NRGNR of Notropis scabriceps, N. stramineus (sand shiner),

Exoglossum laurae (tonguetied minnow), and Phoxinus oreas (mountain redbelly dace) are small and disjunct. The $N$. scabriceps, a New River endemic, is possibly extirpated from tributaries within NRGNR. In 1935, $N$. scabriceps were collected at three sites within or near NRGNR (Addair 1944; and Addair’s records at UMMZ 119243, one specimen from New River 2 miles below Hinton; UMMZ 119256, 17 specimens from Lick Creek; UMMZ 11923672 specimens from Meadow Creek). The NPS reported New River shiners at three mainstem sites during 1988 - 2001, but no recent collections of New River shiner have been made within tributaries. $N$. stramineus was collected once in 1935 at Lick Creek (Addair 1944, not catalogued at UMMZ) and again within the lower gorge by NPS during sampling between 1988 and 2001. E. laurea has a restricted distribution with sites from Wolf Creek, Lick Creek, and the mainstem (1984, 1992, and 1997, respectively; WVDNR unpublished data). P. oreas is restricted primarily to watersheds of Brooks Branch, Farley Creek, and Piney Creek.

Populations within or near NRGNR of Etheostoma nigrum (johnny darter) and Erimystax dissimilis are represented by single locations, with the latter probably extirpated. E. nigrum was collected in 1935 from the headwaters of Glade Creek (Addair 1944, UMMZ 118718, n=1) and above Gauley Bridge (Addair 1944, UMMZ 131828), but was absent from other historic or recent sampling locations within or near NRGNR. E. dissimilis was collected from the mainstem at Prince in 1935 (Addair 1944, UMMZ 119265, n=4), and its absence from all other New River collections supports extirpation. E. nigrum, $N$. scabriceps, E. laurae, and P. oreas often inhabit small streams; hence, larger populations may occur within unsampled headwaters of NRGNR tributaries. 


\section{Nonnatives}

At least 13 of the 40 nongame species within or near the NRGNR are introduced. Some species were collected at few sites and exhibited patchy distributions (e.g. Dorosoma cepedianum, Notropis hudsonius (spottail shiner), Labidesthes sicculus); however, most recent data are from tributaries and do not reflect current distributions of all fishes. However, Cyprinella galactura (whitetail shiner), Notropis telescopus (telescope shiner), Etheostoma caeruleum (rainbow darter), Etheostoma variatum (variegate darter), and Percina roanoka (Roanoke darter) were well represented among the collections, and have exhibited range expansion within NRGNR.

C. galactura is native to the Tennessee River drainage, but researchers have questioned its status in the New River (Jenkins and Burkhead 1994, Stauffer et al. 1995). It was not collected in the New River basin until 1954 in the Virginia portion of the New River (Ross and Carico 1963, Jenkins and Burkhead 1994). These first populations were disjunct and had low abundances. Since the first collections in the New River, the whitetail shiner has exhibited characteristics to that of introduced fishes by rapidly increasing its previously known range and abundance in the New River. It was not collected in the NRGNR until 1988 - 1990 by Easton and Orth (1994). C. galactura is currently distributed throughout the entire NRGNR and is more common in the mainstem than in tributaries (but was seasonally abundant in some tributaries within NRGNR during fall 2002 and fall 2003). We expect congeneric competition between the nonnative whitetail shiner and the native spotfin shiner, but the influence of whitetail shiners on spotfin shiner populations is undocumented.

$N$. telescopus, also native to the Tennessee River drainage, has occurred within the New River system since at least 1958 (Jenkins and Burkhead 1994). This species, first collected from 
West Virginia by Hambrick et al. (1973), continues to expand its range in the New River system (Cincotta et al. 1999). The telescope shiner is widely distributed within the NRGNR, but is more common in the mainstem than in tributaries. We expect telescope shiners to compete with other pelagic native minnows, such as Notropis rubellus (rosyface shiner) and Notropis photogenis (silver shiners), but the influence of $N$. telescopus on native populations is undocumented.

Of eight darter species collected in the NRGNR, three are introduced; rainbow darter (Etheostoma caeruleum), variegate darter (Etheostoma variatum) and Roanoke darter (Percina roanoka) (Jenkins and Burkhead 1994). Etheostoma caeruleum (rainbow darter) was considered rare and possibly native to portions of the New River (Jenkins and Burkhead 1994). However, Jenkins and Burkhead (1993) suggested populations have been introduced into the lower Gauley River system in West Virginia and near the East River near the West Virginia - Virginia border. Recent data indicates range expansion of E. caeruleum within NRGNR. E. caeruleum is currently one of the most widely distributed darters in the NRGNR.

Etheostoma variatum, common in the Ohio River basin, was previously absent above Kanawha Falls in the New River drainage (Jenkins and Burkhead 1994). However, recent collections (Cincotta et al. 1999, Messinger and Chambers 2001, National Park Service unpublished data, data reported herein) indicate the this darter is well established above Kanawha Falls and is distributed widely throughout the length of the NRGNR.

Percina roanoka was first collected in the New River drainage in 1963 (Ross 1969, Hocutt and Hambrick 1973) between Claytor Dam and Bluestone Reservoir. In 1970, it was collected at the mouth of the Greenbrier River, West Virginia, and was considered the most abundant darter within 20 river kilometers downstream of Bluestone Dam (Jenkins and Burkhead 1994). This percid is typically absent from smaller tributaries; hence it is not as widely 
distributed as E. caeruleum. Compiled records indicate that $P$. roanoka is dispersed throughout the mid to upper portions of the NRGNR, mostly in the mainstem.

The New River has eight known endemic fishes: Nocomis platyrhynchus, Phenacobius teretulus, Notropis scabriceps, Percina gymnocephala, Etheostoma kanawhae, Etheostoma osburni, and the Bluestone and cave sculpins. Only Nocomis platyrhynchus and Notropis scabriceps (New River shiner) have been collected in the NRGNR. Nocomis platyrhynchus was sporadic in tributaries and common in the New River mainstem. Notropis scabriceps appears to be declining within NRGNR based on comparisons between current and historic records. $P$. gymnocephala may have been collected by Stauffer et al. (1995) and reported as P. maculata; this record was taken at the mouth of Piney Creek and needs re-examined.

A proportionately high number of Cottus taxa occur in the New River (4 Cottus to 47 native species). However, mottled sculpin (Cottus bairdi) was the only Cottus collected in the NRGNR, where it occurs throughout the Manns Creek watershed. Mottled sculpin also occur within Laurel Creek, at Cotton Hill, West Virginia, just downstream of NRGNR boundaries. Considering its extreme limited distribution, this fish may be a relic of the Pleistocene. Cool water species were isolated to relic populations in tributaries by warmer mainstem temperatures during post-Pleistocene climatic warming (Jenkins and Burkhead 1994). Alternatively, Cottus bairdi populations in Manns Creek and Laurel Creek drainages were possibly established by bait bucket introduction.

\section{CONCLUSION}

The fish fauna of the New River is unique given depauperacy of natives, a high number of nonnatives, and a high number of endemics. The influence of nonnatives on native fishes is an area of concern to the NPS, but actual impacts are undocumented. Further monitoring of 
native and nonnative fish populations is suggested, but do not recommend efforts for removal of nonnatives. Many of the nonnatives have been well established since the late 1800s, and removal efforts would be unsuccessful given the large size of the New River system. Prevention of additional introductions is unlikely, but educational programs aimed at bait bucket releases may reduce further introductions of nonnatives. 


\section{LITERATURE CITED}

Addair, J. 1944. The fishes of the Kanawha River System in West Virginia and some factors which influence their distribution. Ph.D. dissertation. The Ohio State University, Columbus, Ohio.

Cincotta D. A., D.B. Chambers, and T. Messinger. 1999. Recent changes in the distribution of fish species in the New River basin in West Virginia and Virginia. Proceeding of the New River Symposium p.98-106.

Cope, E. D. 1868. On the distribution of fresh-water fishes in the Allegheny region of southwestern Virginia. Journal of the Academy of Natural Sciences of Philadelphia, Series 2, 6, Part 3, Article 5, p. 207-247.

Easton, R. S., D. J. Orth, and N. M. Burkhead. 1993. The first collection of rudd, Scardinius erythrophthalmus (Cyprinidae), in the New River, West Virginia. Journal of Freshwater Ecology 8:263-264

Easton, R. S. and D. J. Orth. 1994. Fishes of the main channel New River, West Virginia. Virginia Journal of Science 45:265-277.

Fuller, P. L., L. G. Nico, and J. D. Williams. 1999. Nonindigenous fishes introduced into inland waters of the United States. American Fisheries Society, Special Publication 27. Bethesda, MD.

Goldsborough, E. L. and H. W. Clark. 1908. Fishes of West Virginia. Bulletin of the Bureau of Fisheries 27:31-39.

Hambrick, P. S., C. H. Hocutt, M. T. Masnik and J. H. Wilson. 1973. Additions to the West Virginia ichthyofauna, with comments on the distribution of other species. Proceeding of the West Virginia Academy of Science 45:58-60.

Herbold, B. and P. B. Moyle. 1986. Introduced species and vacant niches. American Naturalist 128:751-760.

Hess, L. 1983. Preliminary analysis of the food habits of some New River fishes with emphasis on black fly utilization. W. E. Cox and M. Kegley (eds.), Proceedings of New River Symposium. Glen Jean, WV p. 15-21.

Hocutt, C. H. and P. S. Hambrick. 1973. Hybridization between the darter Percina crassa roanoka and Percina oxyrhynca (Percidae, Etheostomatini), with comments on the distribution of Percina crassa roanoka in the New River. American Midland Naturalist 90:397-405. 
Hocutt, C. H., R. F. Denoncourt, and J. R. Stauffer, Jr. 1978. Fishes of the Greenbrier River, West Virginia, with drainage history of the Central Appalachians. Journal of Biogeography 5:59-80.

Hocutt, C. H., R. F. Denoncourt, and J. R. Stauffer, Jr. 1979. Fishes of the Gauley River, West Virginia. Brimleyana 1:47-80.

Hocutt, C. H., R. E. Jenkins, and Stauffer, J. R. 1986. Zoogeography of the fishes of the Central Appalachians and Central Atlantic Coastal Plain, in Hocutt, C. H. and Wiley, E. O., eds., The Zoogeography of North American Freshwater Fishes: New York, John Wiley and Sons, p. 161-211.

Janssen, R. E. 1953. The Teays River, ancient precursor of the East. Scientific Monthly 77:306-314.

Jenkins, R. E., E. A. Lachner, and F. J. Schwartz. 1972. Fishes of the Central Appalachian drainages: Their distribution and dispersal. Virginia Polytechnic Institute and State University Research Division Monograph 4:43-117.

Jenkins, R. E. and N. M. Burkhead. 1993. Freshwater Fishes of Virginia. American Fisheries Society. Bethesda, Maryland.

Lessing, Peter, 1997, Geology of the New River Gorge: accessed at URL http://www.wvgs.wvnet.edu/www/geology/geoles01.htm.

Lobb, M. D., III. 1986. Habitat use by fishes of the New River, West Virginia. M.S. thesis. Virginia Polytechnic Institute State University, Blacksburg, Virginia.

McKeown, P. E., C. H. Hocutt, R. P. Morgan, and J. H. Howard. 1984. An electrophoretic analysis of the Etheostoma variatum complex (Percidae: Etheostomatini), with associated zoogeographic considerations. Environmental Biology of Fishes 11:8595.

Messinger, T. and C.A. Hughes. 2000. Environmental Setting and its relations to water quality in the Kanawha River Basin. U.S. Geological Water-Resources Investigations Report 00-4020.

Messinger, T. and D.B. Chambers. 2001. Fish communities and their relation to environmental factors in the Kanawha River Basin, West Virginia, Virginia, and North Carolina, 1997-98. U.S. Geological Water-Resource Investigation Report 01-4048.

Moyle, P. B. and T. Light. 1996. Fish invasions in California: Do abiotic factors determine success? Ecology 77:1666-1670.

Neves, R. J. 1983. Distributional history of the fish and mussel fauna in the Kanawha River drainage. Proceedings of the New River Symposium 47-67. 
Paybins, K.S., T. Messinger, J.H. Eychaner, D.B. Chambers, and M.D. Kozar. Water quality in the Kanawha-New River Basin, West Virginia, Virginia, and North Carolina, 1996-98. U.S. Geological Survey Circular 1204.

Ross, R. D. 1959. A key to fishes of the Shenandoah River system of Virginia. Virginia Agricultural Experiment Station Technical Bulletin 142.

Ross, R. D. and B. D. Perkins. 1959. Drainage evolution and distribution problems of the fishes of the New (upper Kanawha) River system in Virginia, part 3: records of fishes of the New River. Virginia Agricultural Experiment Station Technical Bulletin 145.

Ross, R. D. and J. E. Carico. 1963. Records and distribution problems of fishes of the North, Middle, and South forks of the Holston River, Virginia. Virginia Agricultural Experiment Station Technical Bulletin 161.

Ross, R. D. 1969. Drainage evolution and fish distribution problems in the southern Appalachians of Virginia, in The Distributional History of the Biota of the Southern Appalachians. Part I: Invertebrates (ed. P. C. Holt). Research Division Monograph No. 1, Virginia Polytechnic Institute and State University, Blacksburg 277-292.

Ross, S. T. 1991. Mechanisms structuring stream fish assemblages: are there lessons to be learned from introduced species? Environmental Biology of Fishes 30:359-368.

Stauffer, J. R., J. M. Boltz, and L. R. White. 1995. The Fishes of West Virginia. Academy of Natural Sciences. Philadelphia, Pennsylvania.

Swift, Ellsworth. 2000. Geology of the New River: Accessed at URL http://www.nps.gov/neri/geology.htm

Ver Steeg, K. 1946. The Teays River. Ohio Journal of Science 46:297-307.

Waite, J. R. and Carpenter, K. D. 2000. Associations among fish assemblage structure and environmental variables in Williamette Basin stream, Oregon. Transactions of the American Fisheries Society 129:754-770.

Wilson, L. and J. M. Purvis. 2000. Water quality monitoring program 1994-1997, New River Gorge National River, Bluestone National Scenic River, and Gauley River National Recreation Area. National Park Service, Glen Jean, West Virginia.

Wood, D. M. 1990. New River Gorge National River water quality study 1989. West Virginia Division of Natural Resources. Charleston, WV. 
Table 1. Sites of fish collections within or near the New River Gorge National River (UMMZ denotes records from University of Michigan Museum of Zoology).

SITE YEAR STREAM

1974 PINEY CREEK

SULLIVAN (21.5 MI UPSTREAM FROM MOUTH), NEAR TAKE-IN CREEK

3

4

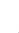

(1)

8

10

\section{3-35 PINEY CREEK}

NEAR COAL CITY, WV

1979 KANAWHA RIVER$$
\text { RIVE }
$$

KANAWHA RIVER JUST BELOW MOUTH OF GAULEY RIVER, GAULEY BRIDGE, WV

1977 NEW RIVER

MAIN CHANNEL NEW RIVER AT MOUTH OF GAULEY

R., GAULEY BRIDGE

LOCATION

UTM_EW UTM_NS Source

$5 \quad 1981$ LITTLE 0.5 MI UPSTREAM FROM SPRAGUE (1.0 MI UPSTREAM WHITESTICK CR. FROM MOUTH)

1978 NEW RIVER

GAULEY BRIDGE - 1.0 MI ABOVE MOUTH

NEW RIVER, JUST UPSTREAM OF CANE BR., GAULEY, WV

UPSTREAM OF TOWN OF RALEIGH

MOUTH OF STREAM AT TOWN OF RALEIGH

DEMPSEY BORE HOLE (JUNCTION OF COUNTY RT 8 \& RT 8/1) 0.3 MI FROM MOUTH

1983 LAUREL CREEK

STA 1 - 6.2 MI ABOVE MOUTH - DEMPSEY, 140 FT

UPSTREAM OF CO RT 8 BRIDGE

1983 LAUREL CREEK

STA 2 - DEMPSEY, 30FT DOWNSTREAM OF MOUTH OF DEMPSEY BR \& 6.0 MI ABOVE MOUTH

1983 LAUREL CREEK

STATION 3 - 0.1 MI UPSTR

5.2 MI ABOVE MOUTH

1978 LAUREL CREEK

1 MI DOWNSTREAM FROM CONFLUENCE WITH DEMPSEY BRANCH (3.7 MI FROM MOUTH)

1979 PINEY CREEK

CONFLUENCE OF PINEY CREEK AND LITTLE BEAVER CK AT US RT 19

1975 DUNLOUP CREEK

1997 PINEY CREEK

MOUNT HOPE (9.0 MI UPSTREAM FROM MOUTH)

UPSTREAM OF BECKLEY STP

1979 LAUREL CREEK

LAUREL CREEK ABOVE AND BELOW OLD MILL AT EXXON STATION AT BECKWITH, WV

1935 LAUREL CREEK

NEAR MOUTH OF JENKINS BR., BECKWITH, WV

1973 LAUREL CREEK

1.3 MI ABOVE MOUTH) COUNTY ROUTE 60/11 - JEEP TRAIL

0.5 MI DOWNSTREAM FROM BECKLEY STP
$481540 \quad 4174080 \quad$ WVDNR

482234

4170301

482478

4223511

Addair (1944)

Stauffer field notes

482668

422349

Stauffer

field notes

$482800 \quad 4182760 \quad$ WVDNR

482860

4223480 WVDNR

484200

4222480 WVDNR

484316

$4222320 \quad$ Addair (1944) and UMMZ

484500

4177850 WVDNR

485071

4178582 WVDNR

485720

4211600 WVDNR

485740

4211600 WVDNR

485800

4211800 WVDNR

4212500 WVDNR

485900

(1)

$486060 \quad 4212660 \quad$ WVDNR

$486160 \quad 4178694 \quad$ Stauffer field notes

$486360 \quad 4195280 \quad$ WVDNR

$486450 \quad 4180275 \quad$ WVDNR

$4864824216554 \quad$ Stauffer field notes

$486597 \quad 4216708 \quad$ Addair (1944)

$486600 \quad 4216740 \quad$ WVDNR

$486620 \quad 4180460 \quad$ WVDNR 
Table 1. continued

1997 BEAVER CREEK GLEN MORGAN AT RT 19 BRIDGE

1975 LAUREL CREEK 0.5 MI UPSTREAM FROM BECKWITH (1.0 MI UPSTREAM FROM MOUTH)

1979 LAUREL CREEK

1 MI UPSTREAM FROM MOUTH (SWIMMING HOLE)

1979 LAUREL CREEK

COUNTY 8 BRIDGE AT DEMPSEY - 5.2 MI FROM MOUTH

1978 LAUREL CREEK

0.5 MI UPSTREAM FROM BECKWITH (1 MI UPSTREAM FROM MOUTH)

1975 LAUREL CREEK

0.25 MI UPSTREAM FROM BECKWITH MILL DAM (0.5 MI UPSTREAM FROM MOUTH)

1979 LAUREL CREEK

BECKWITH (IMMEDIATELY DOWNSTREAM FROM MILL DAM - .5 MI ABOVE MOUTH)

1983 LAUREL CREEK

STATION 4 - 3.0 MI ABOVE MOUTH AT THE "SWIMMING HOLE"

1982 DUNLOUP CREEK

STAR

33-35 NEW RIVER

1979 NEW RIVER

NEW RIVER AT MOUTH OF LAUREL CR., COTTON HILL, WV

NEW RIVER, RT 16 BRIDGE, COTTON HILL WV

1975 DUNLOUP CREEK

1974 PINEY CREEK

RALEIGH (7.0 MI UPSTREAM FROM MOUTH)

1933 BEAVER CREEK

APPROX. 0.5 MI N OF BLUEJAY, WV

1997 LITTLE BEAVER BEHIND KROGER STORE IN BEAVER CR.

1992 ARBUCKLE CREEK CHURCH OFF 17/20, DOWNSTREAM OF OAK HILL

1982 DUNLOUP CREEK

4.0 MILES ABOVE MOUTH - HIGHWAY BRIDGE IN RED STAR

1998 DUNLOUP CREEK

4.25 MILES ABOVE THE MOUTH, AT DEWITT JUST ABOVE CAMPGROUND

1933 BEAVER CREEK APPROX. 1 MI S OF BLUEJAY, WV

1982 DUNLOUP CREEK

3.5 MI ABOVE MOUTH - 200 YDS DOWNSTREAM FROM SEWAGE TREATMENT PLANT

1967 NEW RIVER

HAWKS NEST (7.8 MI UPSTREAM FROM MOUTH)

HAWKS NEST BELOW POWER PLANT (7.8 MI

1982 DUNLOUP CREEK

3.5 FROM SEWAGE TREATMENT PLANT

1998 DUNLOUP CREEK UPSTREAM FROM MOUTH)

\begin{tabular}{|c|c|c|}
\hline 486800 & 4178300 & WVDNR \\
\hline 486900 & 4215900 & WVDNR \\
\hline 486900 & 4216740 & WVDNR \\
\hline 486920 & 4215900 & WVDNR \\
\hline 486920 & 4215900 & WVDNR \\
\hline 486960 & 4217600 & WVDNR \\
\hline 486960 & 4217620 & WVDNR \\
\hline 487100 & 4214640 & WVDNR \\
\hline 487160 & 4198260 & WVDNR \\
\hline 487312 & 4218365 & $\begin{array}{l}\text { Addair } \\
\text { (1944) }\end{array}$ \\
\hline 487373 & 4218237 & $\begin{array}{l}\text { Stauffer } \\
\text { field notes }\end{array}$ \\
\hline 487500 & 4198460 & WVDNR \\
\hline 487940 & 4182380 & WVDNR \\
\hline 488051 & 4177537 & $\begin{array}{l}\text { Addair } \\
\text { (1944) }\end{array}$ \\
\hline 488100 & 4178000 & WVDNR \\
\hline 488200 & 4203280 & WVDNR \\
\hline 488880 & 4198000 & WVDNR \\
\hline 488906 & 4197999 & WVDNR \\
\hline 488919 & 4170441 & $\begin{array}{l}\text { Addair } \\
\text { (1944) }\end{array}$ \\
\hline 489220 & 4197600 & WVDNR \\
\hline 489320 & 4218700 & WVDNR \\
\hline 489320 & 4218700 & WVDNR \\
\hline 489360 & 4197520 & WVDNR \\
\hline 489775 & 4197628 & WVDNR \\
\hline
\end{tabular}
BARREN RUN 
Table 1. continued

\begin{tabular}{|c|c|c|c|c|c|c|}
\hline SITE & YEAR & STREAM & LOCATION & UTM_EW & UTM_NS & Source \\
\hline 47 & 1990 & FAT CREEK & 1.5 MILES ABOVE THE MOUTH & 489840 & 4184600 & WVDNR \\
\hline 48 & 2001 & DUNLOUP CREEK & APPROXIMATELY 2 KM SW OF THURMOND, WV & 490273 & 4198129 & $\begin{array}{l}\text { Welsh } \\
\text { field notes }\end{array}$ \\
\hline 49 & 1982 & FAT CREEK & $\begin{array}{l}\text { MOUTH OF BRAMMER BRANCH ( } 2.5 \text { MI UPSTREAM } \\
\text { FROM MOUTH) }\end{array}$ & 490620 & 4182980 & WVDNR \\
\hline 50 & 1975 & FAT CREEK & $\begin{array}{l}\text { MOUTH OF CYCLONE HOLLOW (3.0 MI UPSTREAM } \\
\text { FROM MOUTH) }\end{array}$ & 490900 & 4183040 & WVDNR \\
\hline 51 & 1964 & DUNLOUP CREEK & $\begin{array}{l}\text { (2 MI UPSTREAM FROM MOUTH) } 4 \text { MI BELOW GLEN } \\
\text { JEAN }\end{array}$ & 490900 & 4198300 & WVDNR \\
\hline 52 & 1997 & FAT CREEK & $\begin{array}{l}\text { APPROX. 100M UPSTREA OF CONFLUENCE WITH } \\
\text { BRAMMER BRANCH }\end{array}$ & 491017 & 4182855 & $\begin{array}{c}\text { Welsh } \\
\text { field notes }\end{array}$ \\
\hline 53 & 2001 & ARBUCKLE CREEK & APPROX 1.9 KM SE OF MINDEN,WV & 491301 & 4202233 & $\begin{array}{l}\text { Welsh } \\
\text { field notes }\end{array}$ \\
\hline 54 & 1983 & MILL CREEK & ANSTED - 2 MI UPSTREAM FROM MOUTH & 491400 & 4220200 & WVDNR \\
\hline 55 & 1998 & PINEY CREEK & $\begin{array}{l}\text { AT RR MARKER3, } 1.5 \text { MILES ABOVE MOUTH, } 0.75 \\
\text { MILES BELOW MOUTH OF FAT CREEK }\end{array}$ & 491404 & 4187397 & WVDNR \\
\hline 56 & 1933 & GLADE CREEK & HEADWATERS, NEAR COOL RIDGE, WV & 491593 & 4165685 & $\begin{array}{l}\text { Addair } \\
(1944)\end{array}$ \\
\hline 57 & 2001 & MARR BRANCH & $\begin{array}{l}\text { APPROXIMATELY } 2 \text { KM NE OF FAYETTEVILLE, WV, } \\
\text { ALONG RT. } 82 .\end{array}$ & 491638 & 4213825 & $\begin{array}{l}\text { Welsh } \\
\text { field notes }\end{array}$ \\
\hline 58 & 1964 & PINEY CREEK & 0.3 MI UPSTREAM FROM MOUTH & 491740 & 4188520 & WVDNR \\
\hline 59 & 1979 & PINEY CREEK & $\begin{array}{l}\text { PINEY CREEK, ST RT } 41 \text { BRIDGE AT MOUTH AT } \\
\text { MCCREERY WV }\end{array}$ & 491767 & 4188862 & $\begin{array}{l}\text { Stauffer } \\
\text { field notes }\end{array}$ \\
\hline 60 & 1979 & NEW RIVER & $\begin{array}{l}\text { MAIN CHANNEL NEW RIVER AT MOUTH OF PINEY } \\
\text { CREEK }\end{array}$ & 491802 & 4188996 & $\begin{array}{l}\text { Stauffer } \\
\text { field notes }\end{array}$ \\
\hline 61 & 2001 & PINEY CREEK & AT MOUTH NEAR MCCREERY, WV. & 491804 & 4188962 & $\begin{array}{l}\text { Welsh } \\
\text { field notes }\end{array}$ \\
\hline 62 & 1964 & NEW RIVER & $\begin{array}{l}\text { MCCREEDY (NEAR PINEY CREEK), 38.0 MI UPSTREAM } \\
\text { FROM MOUTH }\end{array}$ & 491880 & 4189040 & WVDNR \\
\hline 63 & 1999 & NEW RIVER & $\begin{array}{l}\text { POOL IMMEDIATELY UPSTREAM OF MOUTH OF PINEY } \\
\text { CREEK }\end{array}$ & 491995 & 4188931 & WVDNR \\
\hline 64 & 1982 & MILL CREEK & THREE MI UPSTREAM FROM THE MOUTH & 492140 & 4219500 & WVDNR \\
\hline 65 & 1976 & MILL CREEK & $\begin{array}{l}\text { COUNTY ROUTE 5/1 BRIDGE (3.0 MI UPSTREAM FROM } \\
\text { MOUTH) }\end{array}$ & 492140 & 4219500 & WVDNR \\
\hline 66 & 1998 & DUNLOUP CREEK & $\begin{array}{l}\text { 1.O MILE ABOVE MOUTH, ABOVE BRIDGE AT TRAIL } \\
\text { HEAD PARKING AREA }\end{array}$ & 492287 & 4199323 & WVDNR \\
\hline 67 & 1935 & WOLF CREEK & 1 MILE E OF FAYETTEVILLE & 492291 & 4210431 & $\begin{array}{l}\text { Addair } \\
(1944)\end{array}$ \\
\hline 68 & 1984 & WOLF CREEK & $2.5 \mathrm{MI}$ ABOVE MOUTH & 492300 & 4210000 & WVDNR \\
\hline 69 & 1984 & WOLF CREEK & $\begin{array}{l}\text { FAYETTEVILLE WATER IMPOUNDMENT ( } 2.5 \text { MILES } \\
\text { ABOVE MOUTH) }\end{array}$ & 492300 & 4210000 & WVDNR \\
\hline 70 & $01-03$ & MARR BRANCH & $\begin{array}{l}\text { AT MOUTH TO 150 M UPSTREAM APROXIMATELY } 2 \\
\text { KM NNW OF SOUTH FAYETTE, WV }\end{array}$ & 492431 & 4214287 & $\begin{array}{l}\text { David } \\
\text { Wellman }\end{array}$ \\
\hline 71 & 2001 & ARBUCKLE CREEK & AT MOUTH ACROSS NEW RIVER FROM THURMOND & 492453 & 4201454 & $\begin{array}{c}\text { Welsh } \\
\text { field notes }\end{array}$ \\
\hline
\end{tabular}


Table 1. continued

SITE YEAR STREAM

LOCATION

UTM_EW UTM_NS Source

\begin{tabular}{|c|c|c|c|c|c|c|}
\hline 72 & $88-90$ & NEW RIVER & 61.5 RKM DOWNSTREAM OF BLUESTONE DAM & 492610 & 4201351 & $\begin{array}{l}\text { Easton and } \\
\text { Orth } 1994\end{array}$ \\
\hline 73 & $88-01$ & NEW RIVER & 61.5 RKM DOWNSTREAM OF BLUESTONE DAM & 492610 & 4201351 & $\begin{array}{l}\text { J. Purvis - } \\
\text { NPS }\end{array}$ \\
\hline 74 & 1984 & NEW RIVER & 61.5 RKM DOWNSTREAM OF BLUESTONE DAM & 492610 & 4201351 & $\begin{array}{c}\text { M. D. } \\
\text { Lobb } 1986\end{array}$ \\
\hline 75 & 1974 & $\begin{array}{l}\text { LITTLE BEAVER } \\
\text { CR. }\end{array}$ & $\begin{array}{l}500 \text { FT DOWNSTREAM FROM LITTLE BEAVER LAKE } \\
\text { (3.5 MI UPSTREAM FROM MOUTH) }\end{array}$ & 492840 & 4178500 & WVDNR \\
\hline 76 & $01-03$ & WOLF CREEK & ABOVE MOUTH NEAR SOUTH FAYETTE, WV & 492891 & 4211943 & $\begin{array}{l}\text { Welsh } \\
\text { field notes }\end{array}$ \\
\hline 77 & 1979 & WOLF CREEK & $\begin{array}{l}0.1 \text { MI ABOVE MOUTH (NEAR CONFLUENCE WITH } \\
\text { NEW RIVER) }\end{array}$ & 492960 & 4212900 & WVDNR \\
\hline 78 & 1959 & WOLF CREEK & (0.5 MI UPSTREAM FROM MOUTH) & 492980 & 4212180 & WVDNR \\
\hline 79 & 2002 & WOLF CREEK & AT MOUTH NEAR SOUTH FAYETTE, WV BY CR 82 & 493017 & 4212960 & $\begin{array}{c}\text { David } \\
\text { Wellman }\end{array}$ \\
\hline 80 & 33-35 & NEW RIVER & $\begin{array}{l}\text { NEW RIVER AT MOUTH OF WOLF CR., SOUTH } \\
\text { FAYETTE, WV }\end{array}$ & 493029 & 4212994 & $\begin{array}{l}\text { Addair } \\
(1944)\end{array}$ \\
\hline 81 & 1982 & DUNLOUP CREEK & $\begin{array}{l}0.25 \text { MI ABOVE MOUTH - OLD RAILROAD BRIDGE } \\
\text { NEAR THURMOND WV }\end{array}$ & 493040 & 4199920 & WVDNR \\
\hline 82 & 2001 & DUNLOUP CREEK & $\begin{array}{l}\text { AT MOUTH APPROXIMATELY } 1 \text { KM SSE OF } \\
\text { THURMOND, WV }\end{array}$ & 493177 & 4200490 & $\begin{array}{l}\text { Welsh } \\
\text { field notes }\end{array}$ \\
\hline 83 & 1935 & NEW RIVER & NEW RIVER AT THURMOND R.R. STATION & 493210 & 4200632 & $\begin{array}{l}\text { Addair } \\
(1944)\end{array}$ \\
\hline 84 & 1979 & NEW RIVER & $\begin{array}{l}\text { OLD RT } 82 \text { BRIDGE AREA AT BEACH AT FAYETTE } \\
\text { STATION UNDER RT } 19 \text { BRIDGE }\end{array}$ & 493225 & 4212779 & $\begin{array}{l}\text { Stauffer } \\
\text { field notes }\end{array}$ \\
\hline 85 & $88-90$ & NEW RIVER & $\begin{array}{l}\text { 91.5 RKM DOWNSTREAM OF BLUESTONE DAM } \\
\text { UPSTREAM OF WOLF CREEK }\end{array}$ & 493272 & 4212713 & $\begin{array}{l}\text { Easton and } \\
\text { Orth } 1994\end{array}$ \\
\hline 86 & $88-01$ & NEW RIVER & $\begin{array}{l}\text { 91.5 RKM DOWNSTREAM OF BLUESTONE DAM } \\
\text { UPSTREAM OF WOLF CREEK }\end{array}$ & 493272 & 4212713 & $\begin{array}{l}\text { J. Purvis - } \\
\text { NPS }\end{array}$ \\
\hline 87 & 2003 & MILL CREEK & $\begin{array}{l}\text { BRIDGE ON COUNTY ROUTE 5/1 (6.5 MI UPSTREAM } \\
\text { FROM THE MOUTH) }\end{array}$ & 493600 & 4215340 & WVDNR \\
\hline 88 & 1979 & MILL CREEK & $\begin{array}{l}\text { MILL CREEK AT COUNTY ROUTE } 5 \text { BRIDGE IN AMES } \\
\text { HEIGHT WV }\end{array}$ & 493959 & 4214905 & $\begin{array}{l}\text { Stauffer } \\
\text { field notes }\end{array}$ \\
\hline 89 & 01-03 & FERN CREEK & $\begin{array}{l}\text { AT MOUTH TO } 150 \text { M UPSTREAM, APPROXIMATELY } \\
\text { 3.2 KM EAST OF FAYETTEVILLE, WV }\end{array}$ & 493967 & 4211935 & $\begin{array}{c}\text { David } \\
\text { Wellman }\end{array}$ \\
\hline 90 & 1979 & NEW RIVER & $\begin{array}{l}\text { AT BEACH AREA ON LEFT SHORE UPSTREAM OF } \\
\text { STONE CLIFF BRIDGE }\end{array}$ & 494411 & 4198321 & $\begin{array}{l}\text { Stauffer } \\
\text { field notes }\end{array}$ \\
\hline 91 & 1997 & NEW RIVER & MAIN CHANNEL AT STONECLIFF & 494471 & 4198328 & USGS \\
\hline 92 & 1997 & GLADE CREEK & $\begin{array}{l}\text { UPSTREAM OF 5TH CROSSING DOWNSTREAM FROM } \\
\text { BECKLEY WATER PLANT }\end{array}$ & 494500 & 4176000 & WVDNR \\
\hline 93 & $33-35$ & NEW RIVER & NEW RIVER AT MOUTH OF DOWDY CREEK & 494543 & 4192537 & $\begin{array}{l}\text { Addair } \\
(1944)\end{array}$ \\
\hline 95 & 1979 & MILL CREEK & $\begin{array}{l}2.5 \text { MI ABOVE MOUTH ( } 0.5 \text { MI UPSTREAM FROM US RT } \\
\text { 19) }\end{array}$ & 494600 & 4214420 & WVDNR \\
\hline 96 & 1997 & GLADE CREEK & 300 YARDS UPSTREAM OF 3RD CROSSING & 495000 & 4174400 & WVDNR \\
\hline
\end{tabular}

DOWNSTREAM FROM BECKLEY WATER PLANT 
Table 1. continued

\begin{tabular}{|c|c|c|c|c|c|c|}
\hline SITE & YEAR & STREAM & LOCATION & UTM_EW & UTM_NS & Source \\
\hline 97 & 2001 & FERN CREEK & AT RT. 82 BRIDGE AT EDMUND, WV & 495095 & 4212452 & $\begin{array}{c}\text { Welsh } \\
\text { field notes }\end{array}$ \\
\hline 98 & 1996 & GLADE CREEK & $\begin{array}{l}\text { APPROX. 0.5 MI DOWNSTREAM OF BECKLEY WATER } \\
\text { COMPANY DAM }\end{array}$ & 495227 & 4173012 & $\begin{array}{l}\text { Welsh } \\
\text { field notes }\end{array}$ \\
\hline 99 & 1935 & MILL CREEK & NEAR MOUTH & 495304 & 4186784 & $\begin{array}{l}\text { Addair } \\
(1944)\end{array}$ \\
\hline 100 & $88-90$ & NEW RIVER & 41.5 RKM DOWNSTREAM OF BLUESTONE DAM & 495305 & 4189820 & $\begin{array}{l}\text { Easton and } \\
\text { Orth } 1994\end{array}$ \\
\hline 101 & $88-01$ & NEW RIVER & 41.5 RKM DOWNSTREAM OF BLUESTONE DAM & 495305 & 4189820 & $\begin{array}{l}\text { J. Purvis - } \\
\text { NPS }\end{array}$ \\
\hline 102 & 1984 & NEW RIVER & 41.5 RKM DOWNSTREAM OF BLUESTONE DAM & 495305 & 4189820 & $\begin{array}{l}\text { M. D. } \\
\text { Lobb } 1986\end{array}$ \\
\hline 103 & 1975 & GLADE CREEK & $\begin{array}{l}0.5 \text { MI UPSTREAM FROM MOUTH OF PINCH CREEK ( } 6.0 \\
\text { MI UPSTREAM FROM MOUTH) }\end{array}$ & 495380 & 4179300 & WVDNR \\
\hline 104 & 01-03 & MILL CREEK & $\begin{array}{l}\text { AT MOUTH TO } 150 \mathrm{M} \text { UPSTREAM APPROX. } 1.7 \mathrm{KM} \\
\text { NNE OF GRANDVIEW }\end{array}$ & 495496 & 4187056 & $\begin{array}{c}\text { David } \\
\text { Wellman }\end{array}$ \\
\hline 105 & 1935 & NEW RIVER & NEW RIVER AT PRINCE & 495698 & 4189166 & $\begin{array}{l}\text { Addair } \\
(1944)\end{array}$ \\
\hline 106 & 1979 & LAUREL CREEK & $\begin{array}{l}\text { LAUREL CREEK FROM RR BR TO MOUTH, OFF } \\
\text { FAYETTE CO RT 41/27 AT QUINNIMONT WV }\end{array}$ & 495806 & 4189136 & $\begin{array}{l}\text { Stauffer } \\
\text { field notes }\end{array}$ \\
\hline 107 & 2001 & LAUREL CREEK & $\begin{array}{l}\text { AT MOUTH APPROXIMATELY } 0.4 \text { KM SW OF } \\
\text { QUINNIMONT, WV. }\end{array}$ & 496017 & 4189164 & $\begin{array}{l}\text { Welsh } \\
\text { field notes }\end{array}$ \\
\hline 108 & 1933 & GLADE CREEK & NEAR SHADY SPRING & 496190 & 4179491 & $\begin{array}{l}\text { Addair } \\
(1944)\end{array}$ \\
\hline 109 & 1991 & PINCH CREEK & 250 FT UPSTREAM OF MOUTH & 496200 & 4179420 & WVDNR \\
\hline 110 & 2001 & GLADE CREEK & $\begin{array}{l}\text { FROM INTERSTATE } 64 \text { BRIDGE (ABOVE FALLS) TO } \\
\text { MOUTH OF PINCH CREEK. }\end{array}$ & 496277 & 4179577 & $\begin{array}{l}\text { Welsh } \\
\text { field notes }\end{array}$ \\
\hline 111 & 2002 & GLADE CREEK & NEAR I-64 BRIDGE & 496277 & 4179577 & WVDNR \\
\hline 112 & 2001 & PINCH CREEK & $\begin{array}{l}\text { APPROXIMATELY } 200 \mathrm{M} \text { ABOVE MOUTH } \\
\text { APPROXIMATELY } 2.9 \text { KM E OF CROW, WV. }\end{array}$ & 496456 & 4179204 & $\begin{array}{l}\text { Welsh } \\
\text { field notes }\end{array}$ \\
\hline 113 & 1975 & MILL CREEK & $\begin{array}{l}\text { CO. RT. 5/3 CROSSING NEAR THE HEADWATERS (7.5 } \\
\text { MI UPSTREAM FROM THE MOUTH) }\end{array}$ & 496480 & 4214440 & WVDNR \\
\hline 114 & 01-03 & SHORT CREEK & $\begin{array}{l}\text { AT MOUTH APPROXIMATELY } 1.5 \text { KM E OF KAYMOOR, } \\
\text { WV }\end{array}$ & 496790 & 4211190 & $\begin{array}{l}\text { Welsh } \\
\text { field notes }\end{array}$ \\
\hline 115 & 1975 & GLADE CREEK & $\begin{array}{l}\text { 0.25 MI UPSTREAM FROM MOUTH OF KATES BRANCH } \\
\text { (5.0 MI UPSTREAM FROM MOUTH) }\end{array}$ & 496800 & 4180540 & WVDNR \\
\hline 116 & 01-03 & COAL RUN & $\begin{array}{l}\text { AT CUNARD/KAYMOOR TRAILHEAD NEAR CUNARD, } \\
\text { WV }\end{array}$ & 496883 & 4205595 & $\begin{array}{l}\text { Welsh } \\
\text { field notes }\end{array}$ \\
\hline 117 & 01-03 & SLATER CREEK & AT MOUTH TO 150 M UPSTREAM AT THAYER, WV & 497106 & 4194698 & $\begin{array}{l}\text { David } \\
\text { Wellman }\end{array}$ \\
\hline 118 & 2001 & KEENEYS CREEK & AT MOUTH NEAR KEENEYS CREEK, WV & 497436 & 4209552 & $\begin{array}{l}\text { Welsh } \\
\text { field notes }\end{array}$ \\
\hline 119 & $01-03$ & FIRE CREEK & $\begin{array}{l}\text { AT MOUTH TO 160 M UPSTREAM, APPROXIMATELY } \\
\text { 4.7 KM EAST OF THURMOND, WV }\end{array}$ & 497540 & 4200800 & $\begin{array}{l}\text { David } \\
\text { Wellman }\end{array}$ \\
\hline 120 & 01-03 & COAL RUN & $\begin{array}{l}\text { AT MOUTH TO } 150 \text { M APPROXIMATELY 0.5KM NNE } \\
\text { OF CUNARD, WV }\end{array}$ & 497783 & 4206349 & $\begin{array}{c}\text { David } \\
\text { Wellman }\end{array}$ \\
\hline 121 & 01-03 & BUFFALO CREEK & $\begin{array}{l}\text { AT MOUTH TO } \sim 205 \text { M UPSTREAM APPROXIMATELY } 2 \\
\text { KM NNE OF THAYER, WV }\end{array}$ & 497821 & 4195838 & $\begin{array}{c}\text { David } \\
\text { Wellman }\end{array}$ \\
\hline
\end{tabular}


Table 1. continued

\begin{tabular}{|c|c|c|c|c|c|c|}
\hline SITE & YEAR & STREAM & LOCATION & UTM_EW & UTM_NS & Source \\
\hline 122 & 2001 & MANNS CREEK & $\begin{array}{l}\text { AT MOUTH APPROXIMATELY } 0.4 \text { KM N OF SEWELL, } \\
\text { WV }\end{array}$ & 498201 & 4205637 & $\begin{array}{l}\text { Welsh } \\
\text { field notes }\end{array}$ \\
\hline 123 & 1996 & BUFFALO CREEK & 0.4 MILES ABOVE THE MOUTH AT ROAD CROSSING & 498206 & 4196117 & WVDNR \\
\hline 124 & 1997 & BUFFALO CREEK & 0.4 MILE ABOVE THE MOUTH AT ROAD CROSSING & 498300 & 4196200 & WVDNR \\
\hline 125 & 01-03 & EPHRIAM CREEK & $\begin{array}{l}\text { AT MOUTH TO 184M UPSTREAM, APPROXIMATELY } \\
\text { 3.8 KM SOUTH OF SEWELL, WV }\end{array}$ & 498428 & 4201676 & $\begin{array}{c}\text { David } \\
\text { Wellman }\end{array}$ \\
\hline 126 & 2001 & GLADE CREEK & AT MOUTH APPROXIMATELY 1 KM W OF GLADE, WV. & 498876 & 4186662 & $\begin{array}{l}\text { Welsh } \\
\text { field notes }\end{array}$ \\
\hline 127 & 2002 & GLADE CREEK & $\begin{array}{l}\text { AT MOUTH } 50 \text { M UPSTREAM. AT NPS GLADE CREEK } \\
\text { CAMP GROUND }\end{array}$ & 498885 & 4186652 & $\begin{array}{l}\text { David } \\
\text { Wellman }\end{array}$ \\
\hline 128 & 1979 & GLADE CREEK & $\begin{array}{l}\text { GLADE CREEK AT MOUTH ALONG CO RD } \\
\text { PARALLELLING NEW RIVER }\end{array}$ & 498944 & 4186676 & $\begin{array}{l}\text { Stauffer } \\
\text { field notes }\end{array}$ \\
\hline 129 & 1995 & PINCH CREEK & PINCH CREEK & 499115 & 4176352 & WVDNR \\
\hline 130 & 1979 & PINCH CREEK & $\begin{array}{l}\text { 3.5 MI ABOVE MOUTH (.5 MI BELOW COUNTY RT } 22 \\
\text { BRIDGE) }\end{array}$ & 499160 & 4177180 & WVDNR \\
\hline 131 & 1996 & GLADE CREEK & $\begin{array}{l}\text { STA 1, 0.6 MI ABOVE THE MOUTH } 100 \text { YDS ABOVE THE } \\
\text { FALLS (PAST BEDROCK PORTION) }\end{array}$ & 499200 & 4185900 & WVDNR \\
\hline 132 & 1979 & GLADE CREEK & $\begin{array}{l}2 \text { MI BELOW BECKLEY WATER CO DAM, 0.9 MI ABOVE } \\
\text { MOUTH }\end{array}$ & 499360 & 4185460 & WVDNR \\
\hline 133 & 1992 & KEENEY CREEK & 1 MILE UPSTREAM OF MOUTH & 499500 & 4209500 & WVDNR \\
\hline 134 & 1935 & LAUREL CREEK & NEAR TOWN OF LAUREL CREEK, WV & 500566 & 4189745 & $\begin{array}{l}\text { Addair } \\
(1944)\end{array}$ \\
\hline 135 & 1985 & LAUREL CREEK & $\begin{array}{l}\text { WV ROUTE } 41 \text { BRIDGE (LAYLAND) ( } 3.5 \text { MILES ABOVE } \\
\text { MOUTH) }\end{array}$ & 500580 & 4189740 & WVDNR \\
\hline 136 & 1996 & LAUREL CREEK & $\begin{array}{l}\text { STA 1,4.0 MAM, APPROX 1.25 MI BELOW UPPER RT } 41 \\
\text { BRIDGE }\end{array}$ & 501200 & 4190000 & WVDNR \\
\hline 137 & 1996 & LAUREL CREEK & $\begin{array}{l}\text { STA 4, } 5.25 \text { MILES ABOVE THE MOUTH IMMEDIATELY } \\
\text { BELOW UPPER RT } 41 \text { CROSSING }\end{array}$ & 502200 & 4191500 & WVDNR \\
\hline 138 & 1991 & LAUREL CREEK & RT 41 BRIDGE UPSTREAM 100 YDS & 502220 & 4191500 & WVDNR \\
\hline 139 & 1996 & LAUREL CREEK & $\begin{array}{l}\text { STA 3, } 4.75 \text { MILES ABOVE THE MOUTH, } 0.5 \text { MILES } \\
\text { BELOW UPPER RT } 41 \text { CROSSING }\end{array}$ & 502230 & 4191561 & WVDNR \\
\hline 140 & 1996 & $\begin{array}{l}\text { CHESTNUT KNOB } \\
\text { FORK }\end{array}$ & 50 FEET ABOVE MOUTH & 502300 & 4191600 & WVDNR \\
\hline 141 & 2001 & MANNS CREEK & $\begin{array}{l}\text { BELOW CONFLUENCE OF GLADE CREEK, E OF } \\
\text { SEWELL, WV }\end{array}$ & 502306 & 4204784 & $\begin{array}{l}\text { Welsh } \\
\text { field notes }\end{array}$ \\
\hline 142 & 1982 & GLADE CREEK & 1.0 MI ABOVE MOUTH AT END OF TRAM GRADE & 504200 & 4204240 & WVDNR \\
\hline 143 & 2001 & GLADE CREEK & AT BABCOCK STATE PARK, WV & 504501 & 4203839 & $\begin{array}{l}\text { Welsh } \\
\text { field notes }\end{array}$ \\
\hline 144 & 1982 & GLADE CREEK & $\begin{array}{l}2.2 \text { MI ABOVE MOUTH (AT MOUTH OF DAVIS } \\
\text { BRANCH) }\end{array}$ & 504600 & 4202800 & WVDNR \\
\hline 145 & 1979 & GLADE CREEK & GLADE CREEK AT CO RT 19/33 BRIDGE & 504648 & 4202986 & $\begin{array}{l}\text { Stauffer } \\
\text { field notes }\end{array}$ \\
\hline
\end{tabular}


Table 1. continued

\begin{tabular}{|c|c|c|c|c|c|c|}
\hline 146 & 1982 & GLADE CREEK & $\begin{array}{l}\text { 2.0 MI ABOVE MOUTH (400 FT DOWNSTREAM OF } \\
\text { COUNTY RT 19/33 BRIDGE) }\end{array}$ & 504660 & 4203100 & WVDNR \\
\hline 147 & 1979 & MADAM CREEK & MADAM CREEK AT CO RT 3/21 BRIDGE & 506148 & 4169579 & $\begin{array}{l}\text { Stauffer } \\
\text { field notes }\end{array}$ \\
\hline 148 & 1979 & MADAM CREEK & $\begin{array}{l}\text { MADAM CREEK AT CO RT 3/21 BRIDGE, HINTON WV } \\
\text { BELOW FALLS }\end{array}$ & 506160 & 4169572 & $\begin{array}{l}\text { Stauffer } \\
\text { field notes }\end{array}$ \\
\hline 149 & 1992 & FALLS BRANCH & 1/4 MILE UPSTREAM OF MOUTH & 506300 & 4177640 & WVDNR \\
\hline 150 & 1935 & MEADOW CREEK & $\begin{array}{l}\text { MEADOW CREEK AT MOUTH, AT MEADOW CREEK, } \\
\text { WV }\end{array}$ & 506433 & 4184587 & $\begin{array}{l}\text { Addair } \\
(1944)\end{array}$ \\
\hline 151 & 2001 & SEWELL BRANCH & $\begin{array}{l}\text { AT MOUTH APPROXIMATELY } 0.9 \text { KM SSW OF } \\
\text { MEADOW CREEK, WV }\end{array}$ & 506489 & 4183703 & $\begin{array}{l}\text { Welsh } \\
\text { field notes }\end{array}$ \\
\hline 152 & 2001 & MEADOW CREEK & AT MOUTH NEAR MEADOW CREEK, WV. & 506490 & 4184611 & $\begin{array}{l}\text { Welsh } \\
\text { field notes }\end{array}$ \\
\hline 153 & 2001 & MEADOW CREEK & AT MOUTH NEAR MEADOW CREEK, WV & 506490 & 4184611 & WVDNR \\
\hline 154 & 1979 & NEW RIVER & $\begin{array}{l}\text { ALONG SHORELINE UPSTREAM OF MOUTH OF } \\
\text { MEADOW CREEK, MEADOW CREEK WV }\end{array}$ & 506499 & 4184478 & $\begin{array}{l}\text { Stauffer } \\
\text { field notes }\end{array}$ \\
\hline 155 & 2001 & FALLS BRANCH & $\begin{array}{l}\text { AT MOUTH APPROXIMATELY } 3.5 \text { KM SW OF } \\
\text { SANDSTONE, WV. }\end{array}$ & 506611 & 4177487 & $\begin{array}{l}\text { Welsh } \\
\text { field notes }\end{array}$ \\
\hline 156 & 1979 & MEADOW CREEK & $\begin{array}{l}\text { MEADOW CREEK FROM MOUTH UPSTREAM TO } \\
\text { RAILROAD BRIDGE MEADOW CREEK, WV }\end{array}$ & 506646 & 4184848 & $\begin{array}{l}\text { Stauffer } \\
\text { field notes }\end{array}$ \\
\hline 157 & 1997 & MANNS CREEK & 9.26 MILES ABOVE MOUTH NEAR INT OF ST RT 10 & 507114 & 4207012 & WVDNR \\
\hline 158 & 1985 & SMOKY BRANCH & STA 1 - 0.5 MILE UPSTREAM FROM THE MOUTH & 507160 & 4198100 & WVDNR \\
\hline 159 & 01-03 & FARLEYS CREEK & $\begin{array}{l}\text { DOWNSTREAM OF I-64 BOX CULVERT, APPROX. } 2 \text { KM } \\
\text { SSE OF MEADOW CK, WV }\end{array}$ & 507281 & 4181829 & $\begin{array}{c}\text { David } \\
\text { Wellman }\end{array}$ \\
\hline 160 & 1985 & SMOKY BRANCH & STA 2 - 1 MILE UPSTREAM FROM MOUTH & 507340 & 4197520 & WVDNR \\
\hline 161 & 1972 & BURNT CREEK & $\begin{array}{l}0.25 \text { MI UPSTREAM FROM MOUTH) JUST ABOVE } \\
\text { ROUTE } 41\end{array}$ & 507460 & 4197160 & WVDNR \\
\hline 162 & 1985 & SMOKY BRANCH & $\begin{array}{l}\text { STA } 3 \text { - } .25 \text { MILE DOWNSTREAM FROM WV ROUTE } 41 \\
\text { (1.25 MILES ABOVE MOUTH) }\end{array}$ & 507780 & 4197420 & WVDNR \\
\hline 163 & 1979 & NEW RIVER & MAIN CHANNEL NEW RIVER AT SANDSTONE FALLS & 508136 & 4178717 & $\begin{array}{l}\text { Stauffer } \\
\text { field notes }\end{array}$ \\
\hline 164 & 1968 & MEADOW CREEK & $\begin{array}{l}\text { 1.2 MI ABOVE MEADOW CREEK POST OFFICE (1.8 MI } \\
\text { UPSTREAM FROM MOUTH) }\end{array}$ & 508460 & 4186500 & WVDNR \\
\hline 165 & 1972 & GLADE CREEK & $\begin{array}{l}\text { BRIDGE CROSSING } 2 \text { MI ABOVE DANESE ( } 6.75 \text { MI } \\
\text { UPSTREAM FROM MOUTH) }\end{array}$ & 508480 & 4198880 & WVDNR \\
\hline 166 & 1983 & MEADOW CREEK & $\begin{array}{l}\text { STATION } 3 \text { - BEURYTOWN ( } 2.0 \text { MI UPSTREAM FROM } \\
\text { MOUTH) }\end{array}$ & 508500 & 4186560 & WVDNR \\
\hline 167 & 1979 & NEW RIVER & $\begin{array}{l}\text { NEW RIVER } 6.8 \text { ROAD MILES DOWNSTREAM OF } \\
\text { MADAM CREEK }\end{array}$ & 508759 & 4178940 & $\begin{array}{l}\text { Stauffer } \\
\text { field notes }\end{array}$ \\
\hline 168 & 2003 & NEW RIVER & I-65 BRIDGE AT SANDSTONE & 508819 & 4181275 & WVDNR \\
\hline 169 & 1979 & NEW RIVER & $\begin{array}{l}\text { MAIN CHANNEL NEW RIVER } 1.5 \text { ROAD MILES } \\
\text { DOWNSTREAM OF MADAM CREEK AT ISLAND }\end{array}$ & 509128 & 4168486 & $\begin{array}{l}\text { Stauffer } \\
\text { field notes }\end{array}$ \\
\hline
\end{tabular}


Table 1. continued

\begin{tabular}{|c|c|c|c|c|c|c|}
\hline SITE & YEAR & STREAM & LOCATION & UTM_EW & UTM_NS & Source \\
\hline 170 & 1979 & NEW RIVER & $\begin{array}{l}\text { NEW RIVER 'ISLAND STATION' DOWNSTREEAM } \\
\text { ABOUT 0.75 ROAD MILE FROM MADAM CR. }\end{array}$ & 509158 & 4168504 & $\begin{array}{l}\text { Stauffer } \\
\text { field notes }\end{array}$ \\
\hline 171 & 1979 & NEW RIVER & $\begin{array}{l}\text { MAIN CHANNEL NEW RIVER JUST BELOW MOUTH OF } \\
\text { MEADOW CREEK AT HINTON, WV }\end{array}$ & 509178 & 4169266 & $\begin{array}{l}\text { Stauffer } \\
\text { field notes }\end{array}$ \\
\hline 172 & 1998 & MEADOW CREEK & $\begin{array}{l}2.5 \text { MILES ABOVE THE MOUTH, AT CONFLUENCE OF } \\
\text { LEFTHAND FORK }\end{array}$ & 509182 & 4187180 & WVDNR \\
\hline 173 & 1979 & NEW RIVER & $\begin{array}{l}\text { MAIN CHANNEL NEW RIVER AT MOUTH OF MADAM } \\
\text { CREEK }\end{array}$ & 509201 & 4169314 & $\begin{array}{l}\text { Stauffer } \\
\text { field notes }\end{array}$ \\
\hline 174 & 1992 & NEW RIVER & POOL AT LAUREL CREEK BRIDGE & 509300 & 4179900 & WVDNR \\
\hline 175 & 1997 & NEW RIVER & LAUREL CREEK POOL & 509300 & 4180065 & WVDNR \\
\hline 176 & 1953 & LICK CREEK & NEAR SANDSTONE ON WV 20 & 509325 & 4180847 & WVDNR \\
\hline 177 & 2001 & LICK CREEK & $\begin{array}{l}\text { AT MOUTH APPROXIMATELY } 1 \text { KM N OF SANDSTONE, } \\
\text { WV }\end{array}$ & 509327 & 4180885 & $\begin{array}{l}\text { Welsh } \\
\text { field notes }\end{array}$ \\
\hline 178 & $88-90$ & NEW RIVER & $\begin{array}{l}\text { 16.5 RKM DOWNSTREAM OF BLUESTONE DAM JUST } \\
\text { UPSTREAM OF SANDSTONE FALLS }\end{array}$ & 509333 & 4180197 & $\begin{array}{l}\text { Easton and } \\
\text { Orth } 1994\end{array}$ \\
\hline 179 & $88-01$ & NEW RIVER & $\begin{array}{l}\text { 16.5 RKM DOWNSTREAM OF BLUESTONE DAM JUST } \\
\text { UPSTREAM OF SANDSTONE FALLS }\end{array}$ & 509333 & 4180197 & $\begin{array}{l}\text { J. Purvis - } \\
\text { NPS }\end{array}$ \\
\hline 180 & 1984 & NEW RIVER & $\begin{array}{l}\text { 16.5 RKM DOWNSTREAM OF BLUESTONE DAM JUST } \\
\text { ABOVE SANDSTONE FALLS }\end{array}$ & 509333 & 4180197 & $\begin{array}{c}\text { M. D. } \\
\text { Lobb } 1986\end{array}$ \\
\hline 181 & 1963 & NEW RIVER & HINTON - 61.0 MI UPSTREAM FROM MOUTH & 509340 & 4169240 & WVDNR \\
\hline 182 & 1966 & NEW RIVER & $\begin{array}{l}\text { 8.2 MI BELOW HINTON - } 55.5 \text { MI UPSTREAM FROM } \\
\text { MOUTH }\end{array}$ & 509360 & 4180160 & WVDNR \\
\hline 183 & 2000 & NEW RIVER & POOL AT MOUTH OF LAUREL CREEK & 509390 & 4180416 & WVDNR \\
\hline 184 & 1979 & NEW RIVER & $\begin{array}{l}\text { MAIN CHANNEL NEW RIVER AT MOUTH OF LAUREL } \\
\text { CREEK AT SANDSTONE WV }\end{array}$ & 509400 & 4180065 & $\begin{array}{l}\text { Stauffer } \\
\text { field notes }\end{array}$ \\
\hline 185 & 1979 & LAUREL CREEK & $\begin{array}{l}\text { LAUREL CREEK AT MOUTH TO 200' ABOVE FIRST } \\
\text { RIFFLE }\end{array}$ & 509486 & 4180026 & $\begin{array}{l}\text { Stauffer } \\
\text { field notes }\end{array}$ \\
\hline 186 & 2001 & LAUREL BRANCH & AT MOUTH NEAR SANDSTONE, WV & 509546 & 4180035 & $\begin{array}{l}\text { Welsh } \\
\text { field notes }\end{array}$ \\
\hline 187 & 2001 & MEADOW CREEK & NE OF MEADOW CREEK, WV & 509570 & 4187282 & $\begin{array}{l}\text { Welsh } \\
\text { field notes }\end{array}$ \\
\hline 188 & 1992 & LICK CREEK & 1/2 MILE UPSTREAM OF MOUTH & 509600 & 4181600 & WVDNR \\
\hline 189 & 1968 & LICK CREEK & $\begin{array}{l}\text { 1/2 MI ABOVE SANDSTONE - } 0.5 \text { MI UPSTREAM FROM } \\
\text { MOUTH }\end{array}$ & 509620 & 4181500 & WVDNR \\
\hline 190 & 3195 & NEW RIVER & NEW RIVER, 2 MI BELOW HINTON & 509688 & 4172610 & $\begin{array}{l}\text { Addair } \\
(1944)\end{array}$ \\
\hline 191 & 01-03 & BROOKS BRANCH & AT MOUTH NEAR BASS LAKE, BARKSDALE, WV & 509814 & 4173314 & $\begin{array}{l}\text { Welsh } \\
\text { field notes }\end{array}$ \\
\hline 192 & 1969 & NEW RIVER & $\begin{array}{l}\text { BELOW BRIDGE BELOW BLUESTONE DAM ( } 63.5 \text { MI } \\
\text { UPSTREAM FROM MOUTH) }\end{array}$ & 509900 & 4167000 & WVDNR \\
\hline 193 & 1975 & MEADOW CREEK & MEADOW BRIDGE (3.0 MI UPSTREAM FROM MOUTH) & 509940 & 4187440 & WVDNR \\
\hline 194 & 1970 & NEW RIVER & $\begin{array}{l}\text { BLUESTONE DAM TO MOUTH OF GREENBRIER RIVER } \\
\text { - } 63.5 \text { MI UPSTREAM FROM MOUTH }\end{array}$ & 510120 & 4166500 & WVDNR \\
\hline
\end{tabular}


Table 1. continued

\begin{tabular}{|c|c|c|c|c|c|c|}
\hline SITE & YEAR & STREAM & LOCATION & UTM_EW & UTM_NS & Source \\
\hline 195 & 1974 & $\begin{array}{l}\text { GREENBRIER } \\
\text { RIVER }\end{array}$ & $\begin{array}{l}\text { MOUTH OF GREENBRIER RIVER, HINTON, WV, RT } 3 \\
\text { BRIDGE }\end{array}$ & 510188 & 4167082 & $\begin{array}{l}\text { Stauffer } \\
\text { field notes }\end{array}$ \\
\hline 196 & 1983 & MEADOW CREEK & $\begin{array}{l}\text { STATION } 2 \text { - CLAYPOOL (4.0 MI UPSTREAM FROM } \\
\text { MOUTH) }\end{array}$ & 511160 & 4187340 & WVDNR \\
\hline 197 & 1998 & MEADOW CREEK & $\begin{array}{l}4 \text { MILES ABOVE THE MOUTH, 100YRDS BELOW } \\
\text { MOUTH OF CLAYPOOL BRANCH }\end{array}$ & 511193 & 4187343 & WVDNR \\
\hline 198 & 2001 & MEADOW CREEK & AT RT. 24 BRIDGE S OF MEADOW BRIDGE, WV. & 512352 & 4189074 & $\begin{array}{l}\text { Welsh } \\
\text { field notes }\end{array}$ \\
\hline 199 & 1983 & MEADOW CREEK & $\begin{array}{l}\text { 0.5 MI UPSTREAM FROM MEADOW BRIDGE ( } 7 \text { MI } \\
\text { UPSTREAM FROM MOUTH) }\end{array}$ & 512560 & 4190700 & WVDNR \\
\hline 200 & 1983 & MEADOW CREEK & $\begin{array}{l}\text { STATION } 1 \text { - } 0.5 \text { MI UPSTREAM FROM MEADOW } \\
\text { BRIDGE (7 MI UPSTREAM FROM MOUTH) }\end{array}$ & 512580 & 4190700 & WVDNR \\
\hline 201 & 1935 & MEADOW CREEK & CA 5 MI ABOVE MOUTH & 512722 & 4189955 & $\begin{array}{l}\text { Addair } \\
(1944)\end{array}$ \\
\hline 202 & 1972 & GLADE CREEK & $\begin{array}{l}\text { (8.5 MI UPSTREAM FROM MOUTH)-ALONG SECOND RT } \\
\text { 60/16 APPROX } 2 \text { MI SO OF RT } 60\end{array}$ & 513200 & 4201160 & WVDNR \\
\hline 203 & 1976 & GLADE CREEK & $\begin{array}{l}\text { COUNTY ROUTE } 41 / 7 \text { BRIDGE (10.0 MI UPSTREAM } \\
\text { FROM MOUTH) }\end{array}$ & 513840 & 4202040 & WVDNR \\
\hline 204 & 1935 & LICK CREEK & NEAR GREEN SULPHUR SPRINGS, WV & 515678 & 4183904 & $\begin{array}{l}\text { Addair } \\
(1944)\end{array}$ \\
\hline 205 & 1979 & LICK CREEK & $\begin{array}{l}\text { LICK CREEK JUST ABOVE CONFLUENCE WITH MILL } \\
\text { CREEK ALONG CO RT } 4\end{array}$ & 516296 & 4184066 & $\begin{array}{l}\text { Stauffer } \\
\text { field notes }\end{array}$ \\
\hline 206 & 1979 & MILL CREEK & $\begin{array}{l}\text { MILL CREEK CO RT } 4 \text { BRIDGE AT GREEN SULPHUR } \\
\text { SPRINGS }\end{array}$ & 516587 & 4183549 & $\begin{array}{l}\text { Stauffer } \\
\text { field notes }\end{array}$ \\
\hline 207 & 1928 & DUNLOUP CREEK & $\begin{array}{l}\text { NEAR GLEN JEAN - MAY BE SAME AS ADDAIR, BUT } \\
\text { ADDAIR LISTED NO FISH }\end{array}$ & 486954 & 4197782 & $\begin{array}{l}\text { UMMZ } \\
\text { (Hubbs } \\
\text { and } \\
\text { Hubbs) }\end{array}$ \\
\hline 208 & 33-35 & DUNLOUP CREEK & $\begin{array}{l}\text { DUNLOUP CREEK, LISTED AS LITTLE LOOP CR. [NEAR } \\
\text { GLEN JEAN] }\end{array}$ & 486954 & 4197782 & $\begin{array}{l}\text { Addair } \\
(1944)\end{array}$ \\
\hline 209 & 33-35 & PINEY CREEK & NEAR FITZPATRICK, WV & 481559 & 4176996 & $\begin{array}{l}\text { Addair } \\
\text { (1944) and } \\
\text { UMMZ }\end{array}$ \\
\hline 210 & 1935 & PINEY CREEK & CA 1 MI BELOW WRIGHT & 491553 & 4188290 & $\begin{array}{l}\text { Addair } \\
\text { (UMMZ) }\end{array}$ \\
\hline
\end{tabular}




\section{New River Gorge National River, West Virginia}

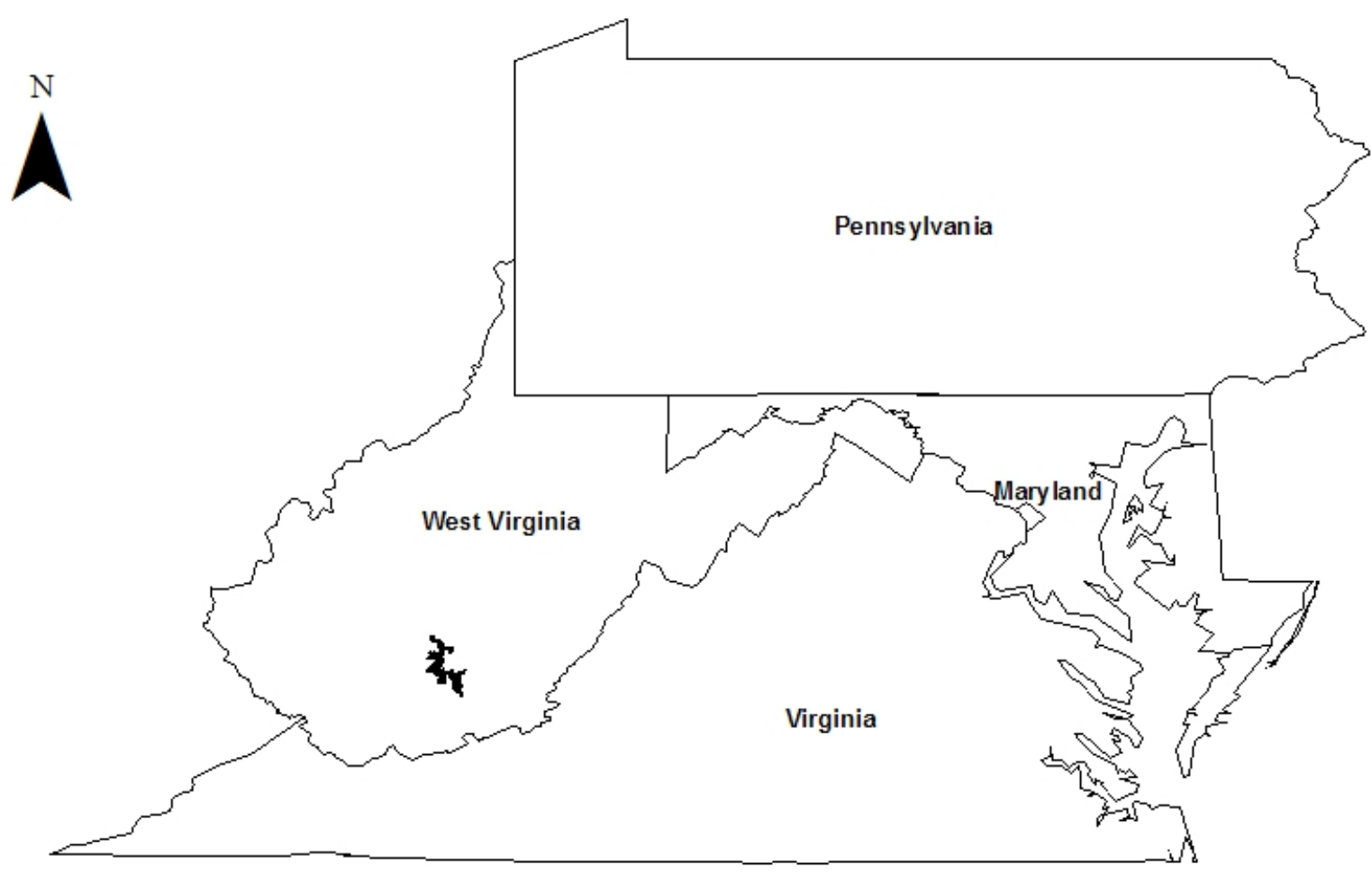

Legend

New River Gorge National River

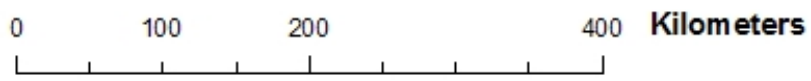

Figure 1. Location of New River Gorge National River in southern West Virginia. 


\section{Fish Collection Sites from 1928 - 2003}

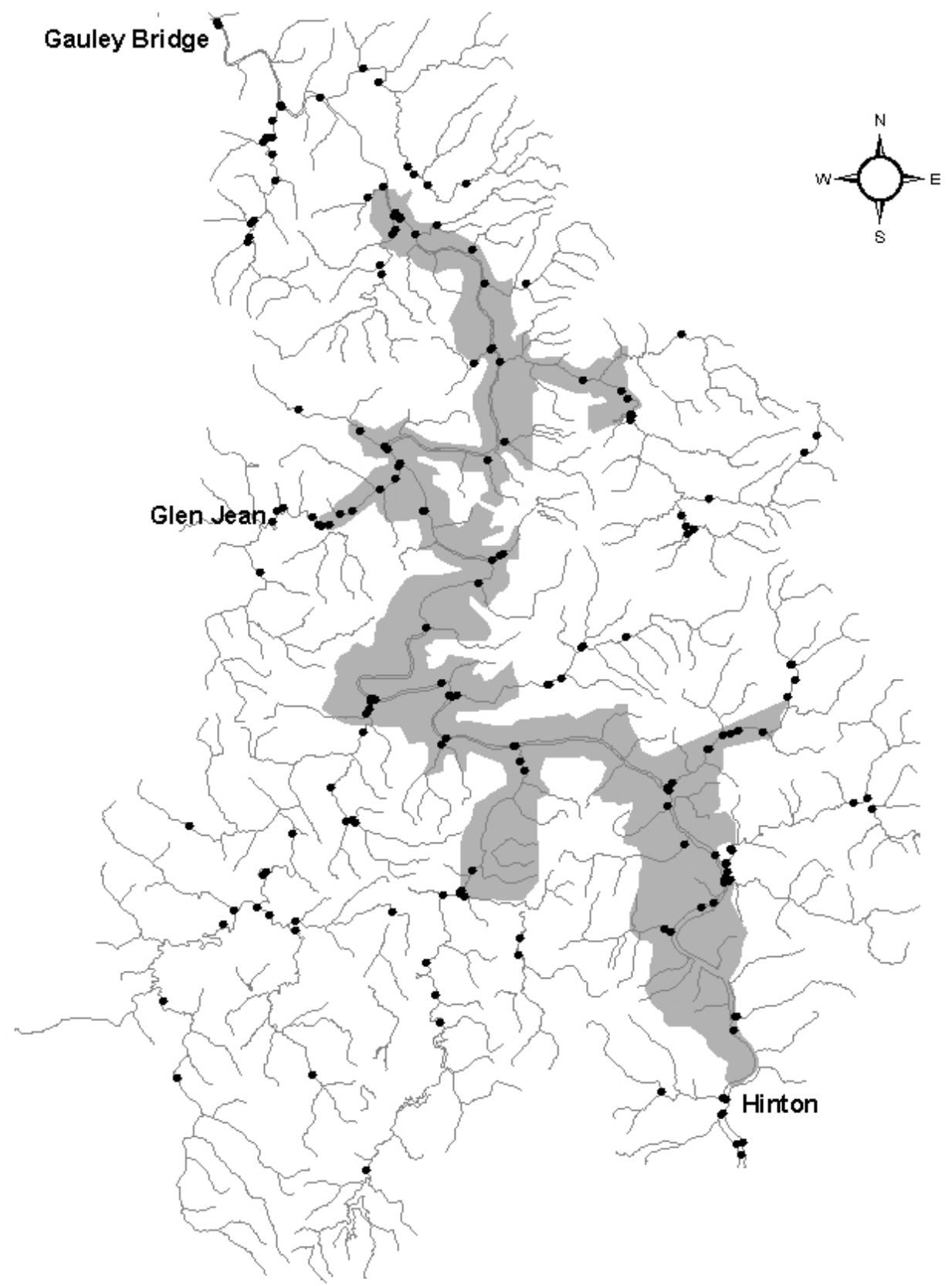

Fish collection sites 1928 - 2003

New River and tributaries

NRGNR boundary

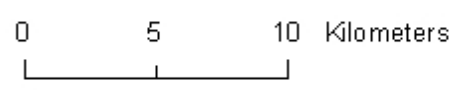

Figure 2. Sites of fish collections (1928 - 2003) within or near the New River Gorge National River. Location descriptions are in Table 1. 


\section{Dorosoma cepedianum (gizzard shad)}

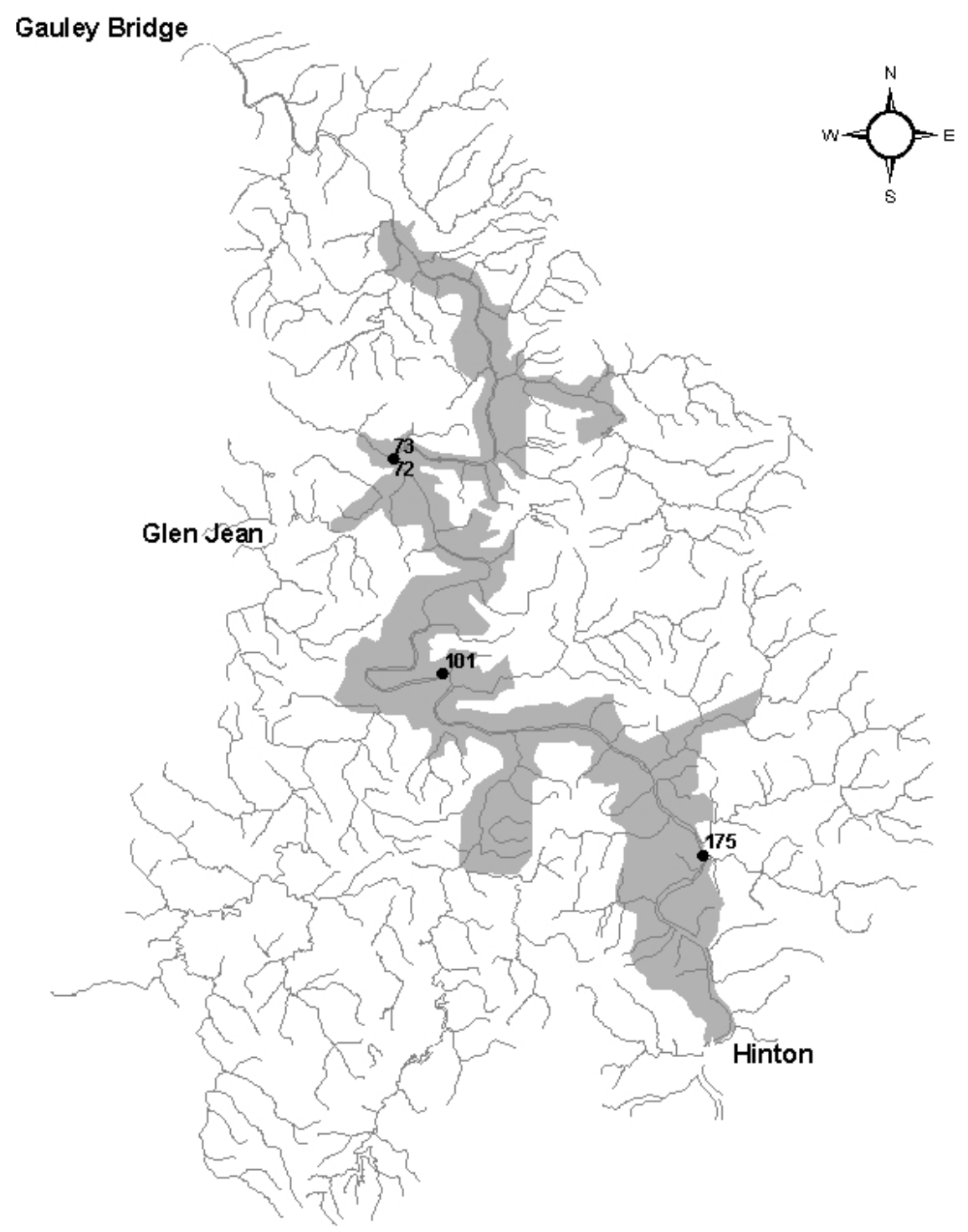

- Dorosoma cepedianum

New River and tributaries

NRGNR boundary

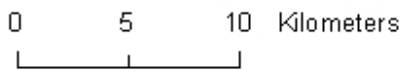

Figure 3. Collection sites for Dorosoma cepedianum (gizzard shad) within and near the New River Gorge National River. 


\section{Esox masquinongy (muskellunge)}

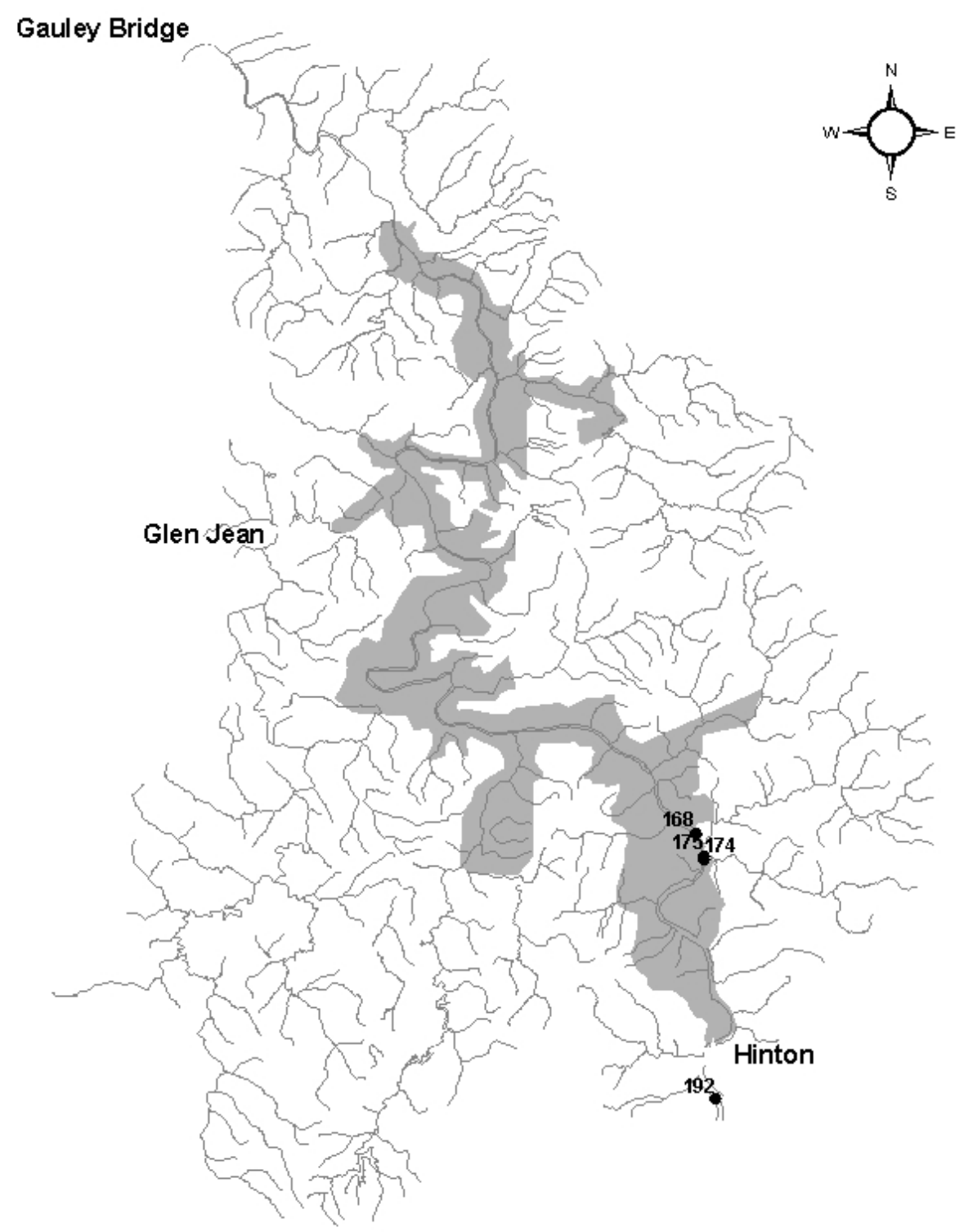

- Esox masquinongy

New River and tributaries

NRGNR boundary

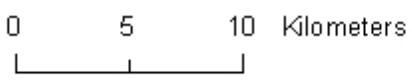

Figure 4. Collection sites for Esox masquinongy (muskellunge) within and near the New River Gorge National River. 


\section{Campostoma anomalum (central stoneroller)}

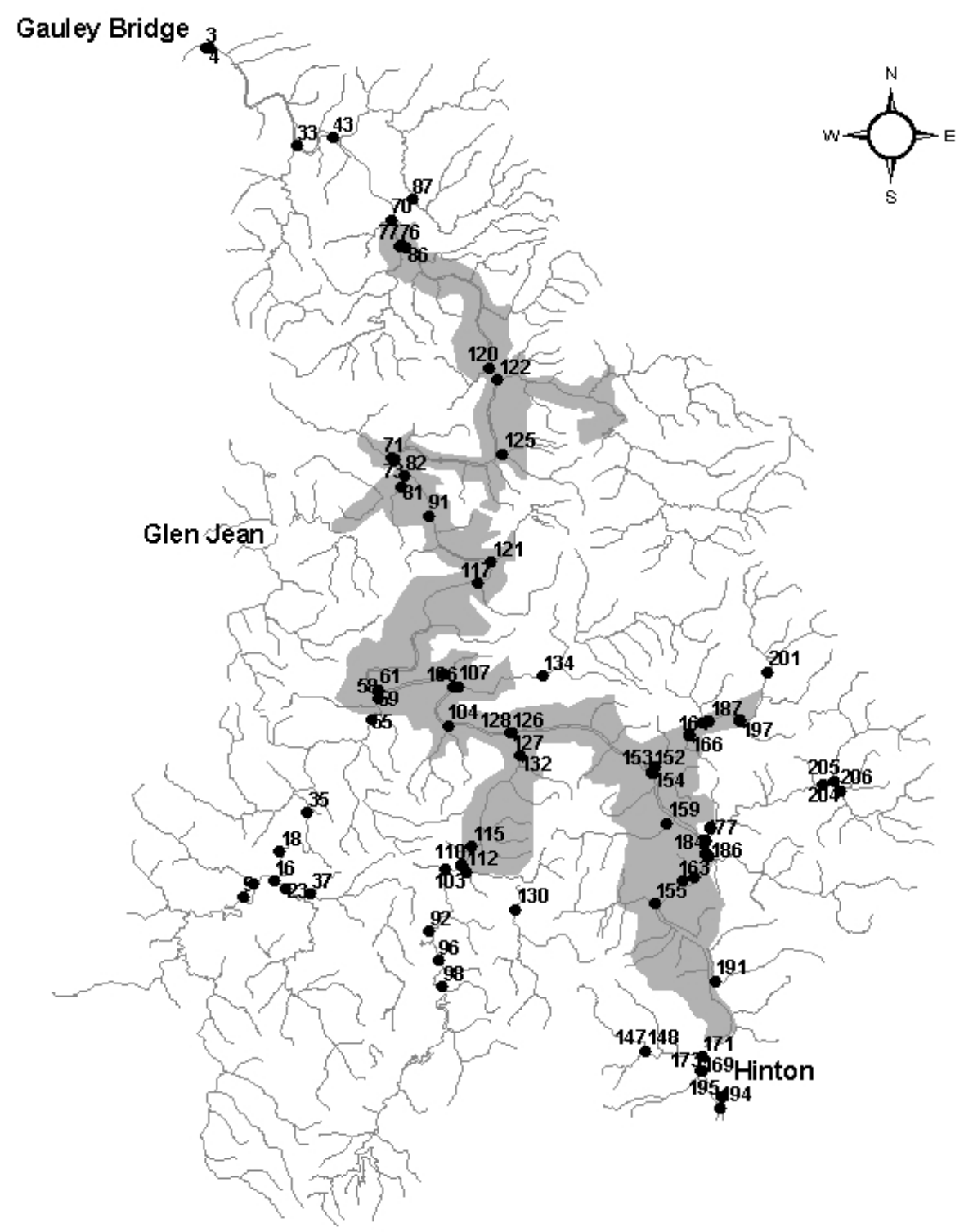

- Campostoma anomalum

- New River and tributaries NRGNR boundary

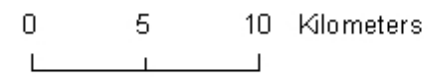

Figure 5. Collection sites for Campostoma anomalum (central stoneroller) within and near the New River Gorge National River. 


\section{Clinostomus funduloides (rosyside dace)}

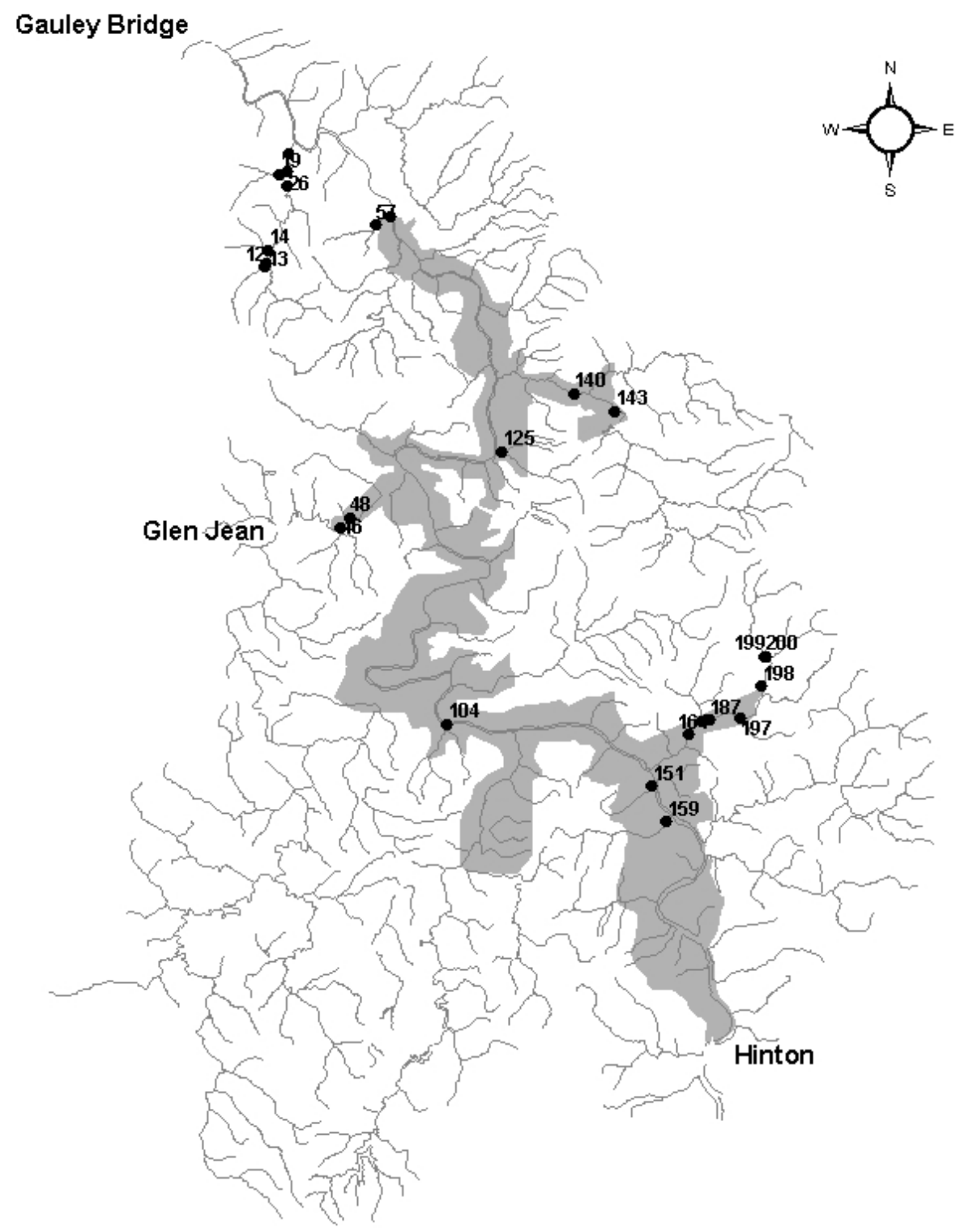

- Clinostomus funduloides

- New River and tributaries NRGNR boundary

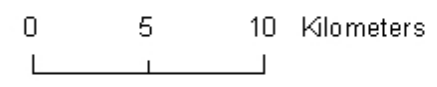

Figure 6. Collection sites for Clinostomus funduloides (rosyside dace) within and near the New River Gorge National River. 


\section{Cyprinella galactura (whitetail shiner)}

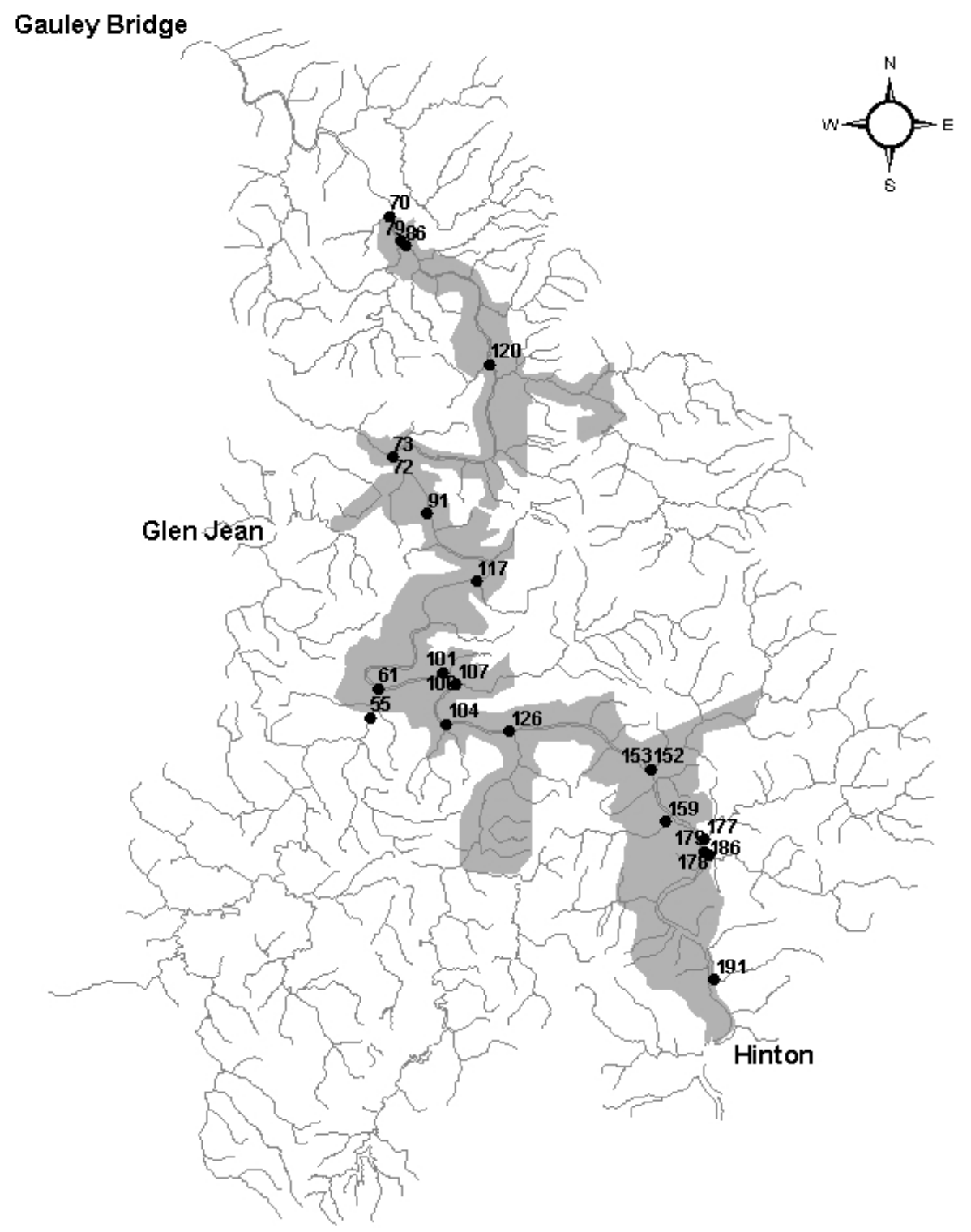

- Cyprinella galactura

New River and tributaries

NRGNR boundary

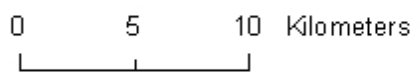

Figure 7. Collection sites for Cyprinella galactura (whitetail shiner) within and near the New River Gorge National River. 


\section{Cyprinella spiloptera (spotfin shiner)}

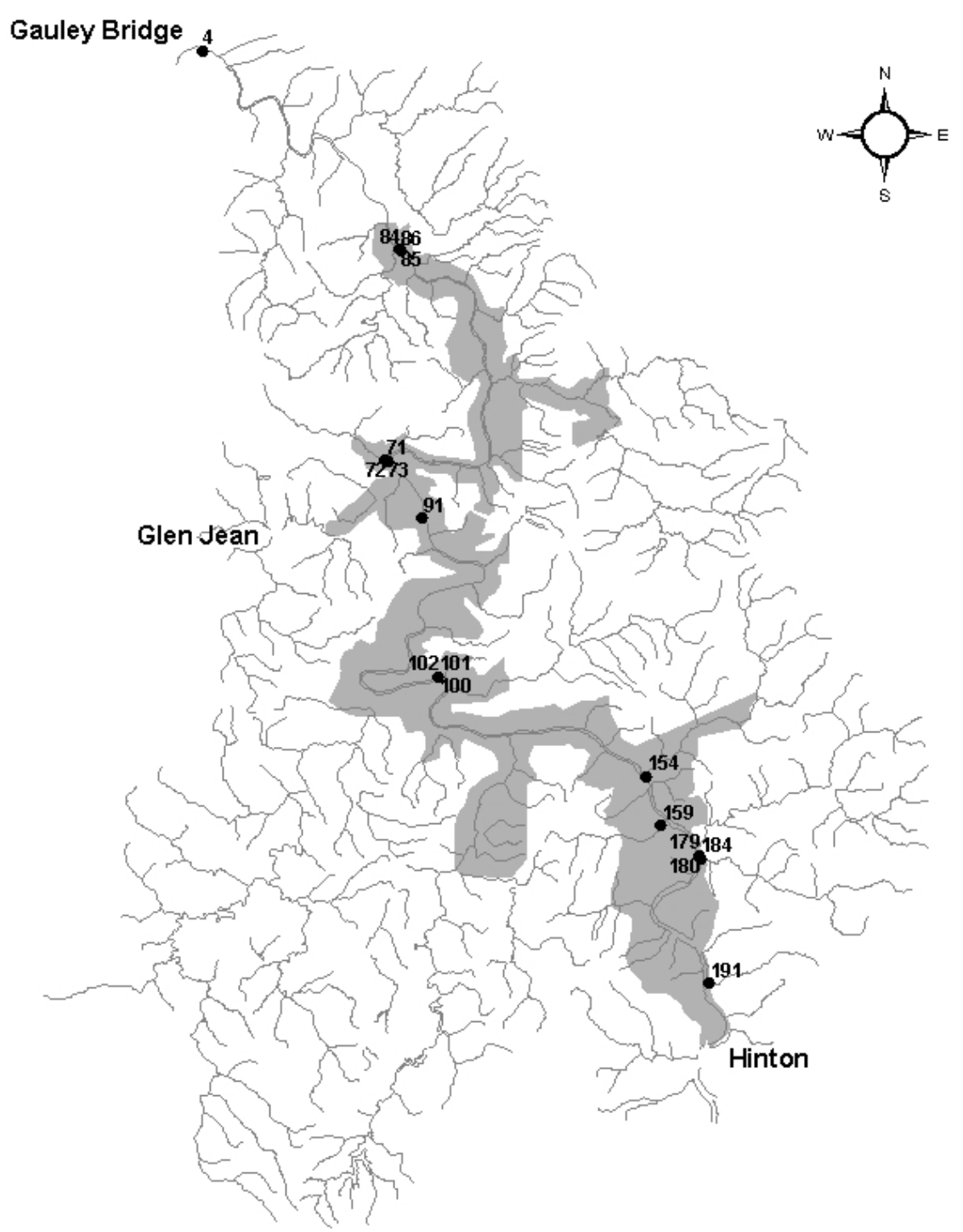

- Notropis hudsonius

New River and tributaries

NRGNR boundary

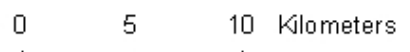

Figure 8. Collection sites for Cyprinella spiloptera (spotfin shiner) within and near the New River Gorge National River. 


\section{Cyprinus carpio (common carp)}

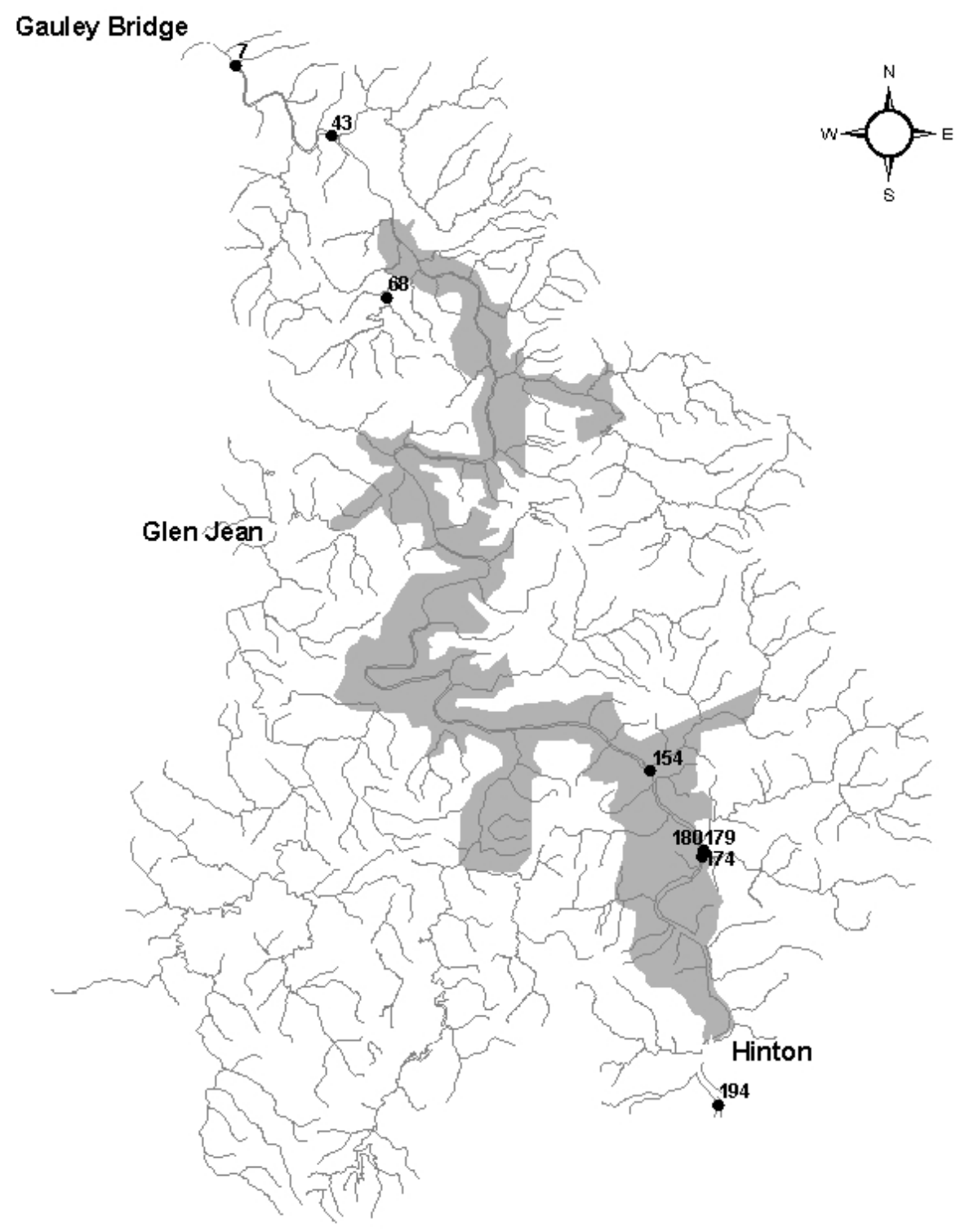

- Cyprinus carpio

- New River and tributaries

NRGNR boundary

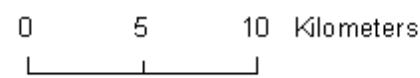

Figure 9. Collection sites for Cyprinus carpio (common carp) within and near the New River Gorge National River. 


\section{Ericymba buccata (silverjaw minnow)}

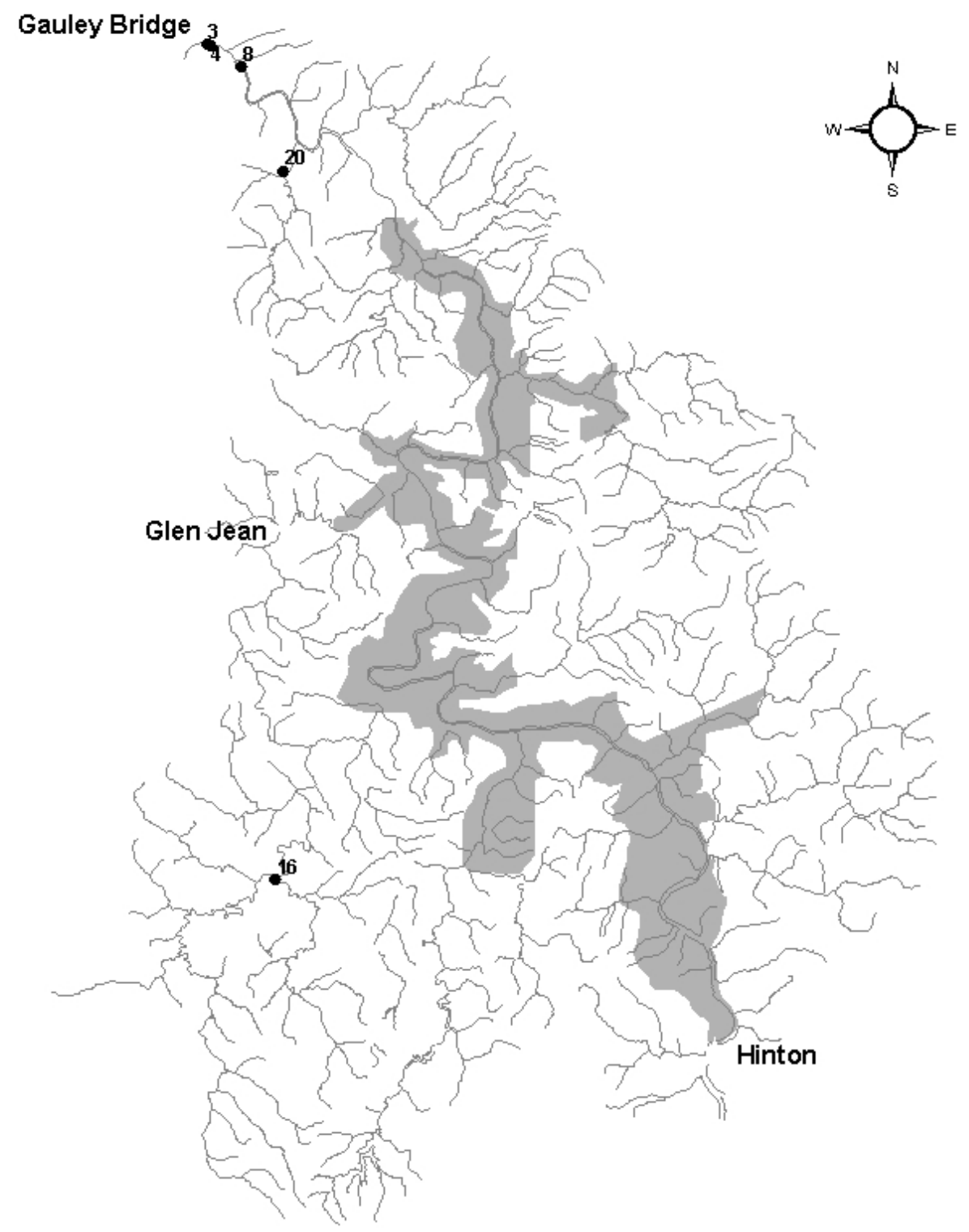

- Ericymba buccata

New River and tributaries

NRGNR boundary

Figure 10. Collection sites for Ericymba buccata (silverjaw minnow) within and near the New River Gorge National River. 


\section{Erimystax dissimilis (streamline chub)}

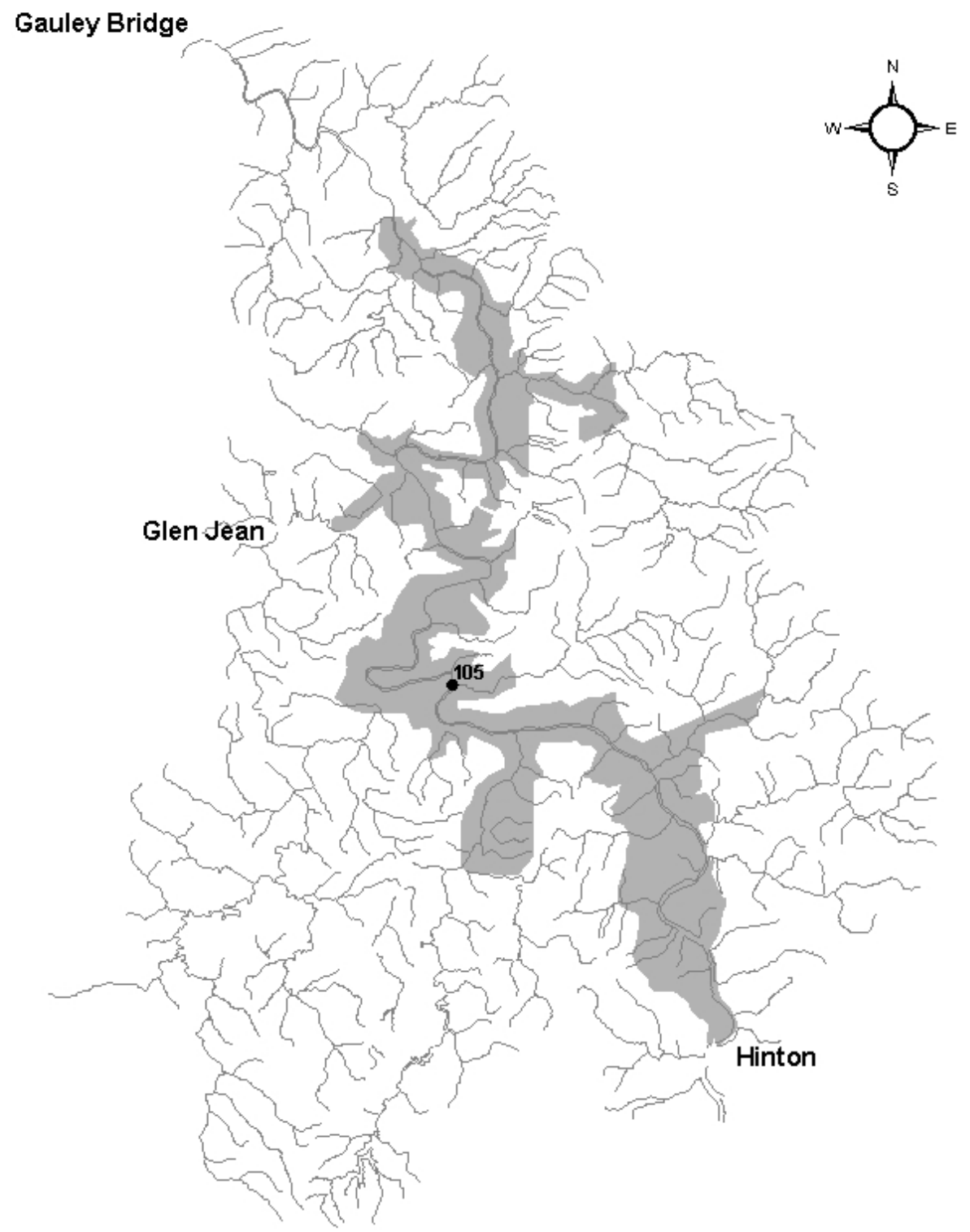

- Erimystax dissimilis

New River and tributaries

NRGNR boundary

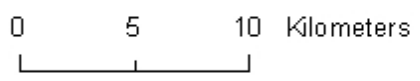

Figure 11. Collection sites for Erimystax dissimilis (streamline chub) within and near the New River Gorge National River. 


\section{Exoglossum laurae (tonguetied minnow)}

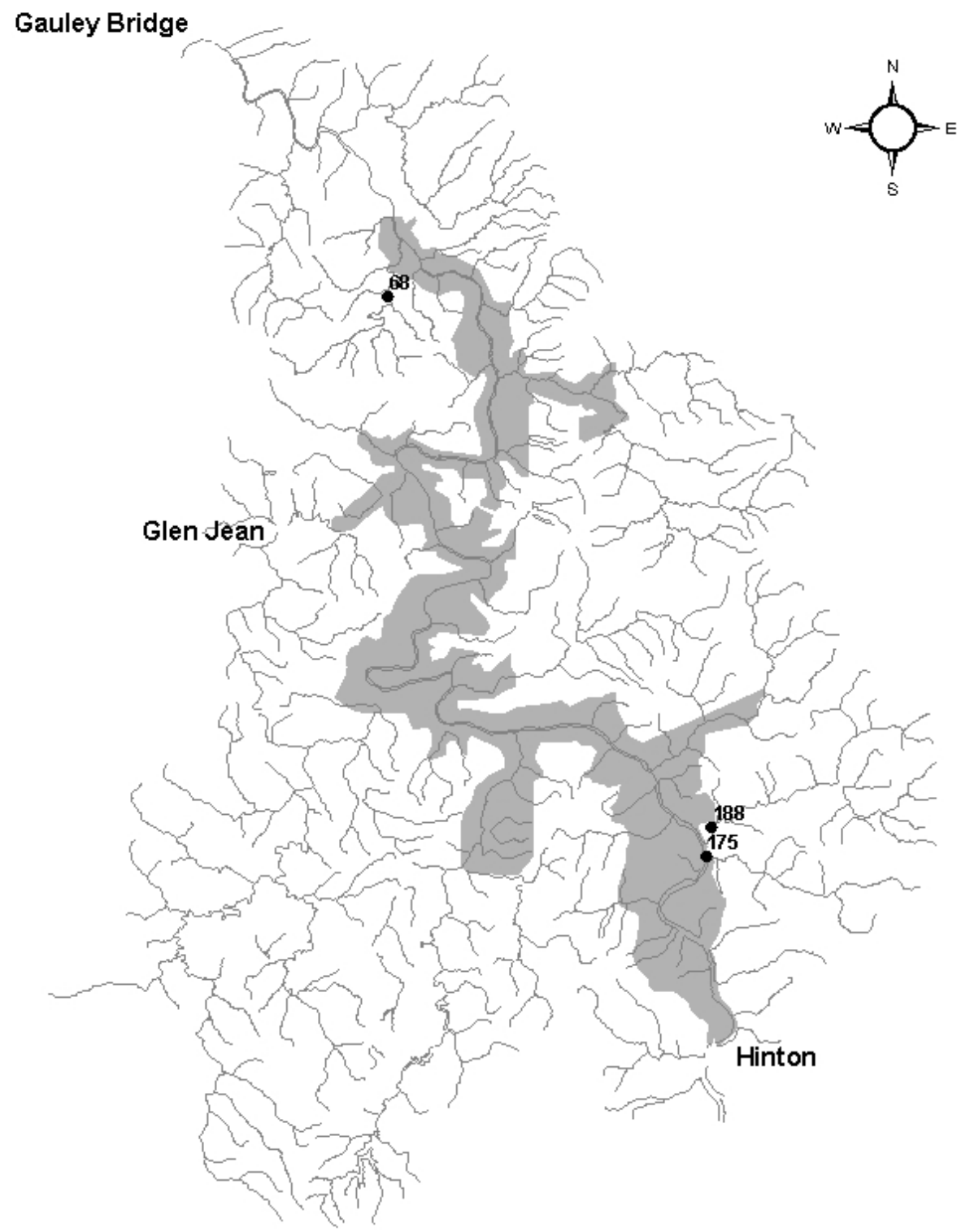

- Exoglossum laurae

New River and tributaries

NRGNR boundary

Figure 12. Collection sites for Exoglossum laurae (tonguetied minnow) within and near the New River Gorge National River. 


\section{Luxilus albeolus (white shiner)}

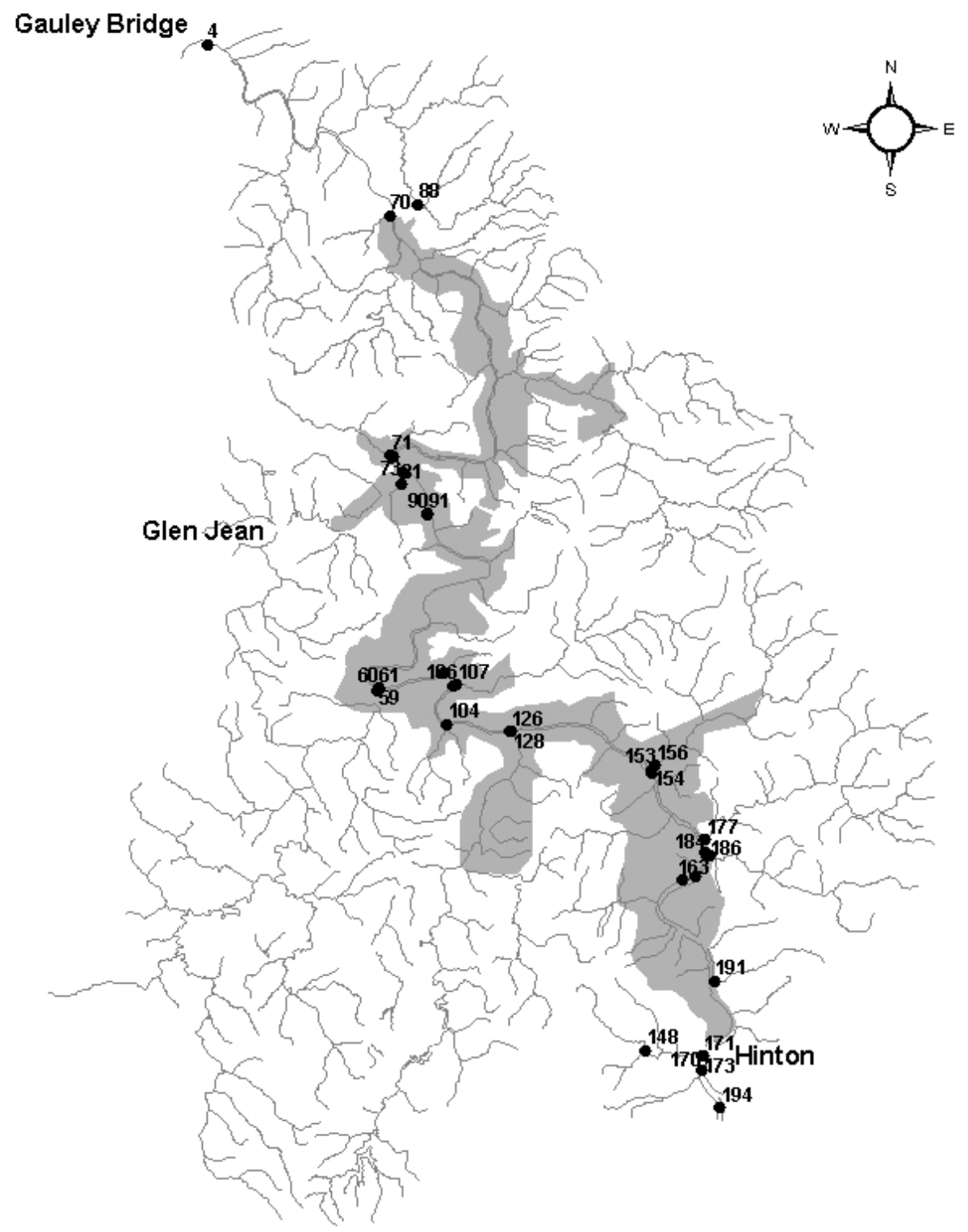

- Luxilus albeolus

New River and tributaries

NRGNR boundary

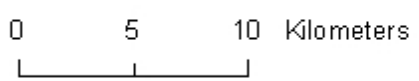

Figure 13. Collection sites for Luxilus albeolus (white shiner) within and near the New River Gorge National River. 


\section{Luxilus chrysocephalus (striped shiner)}

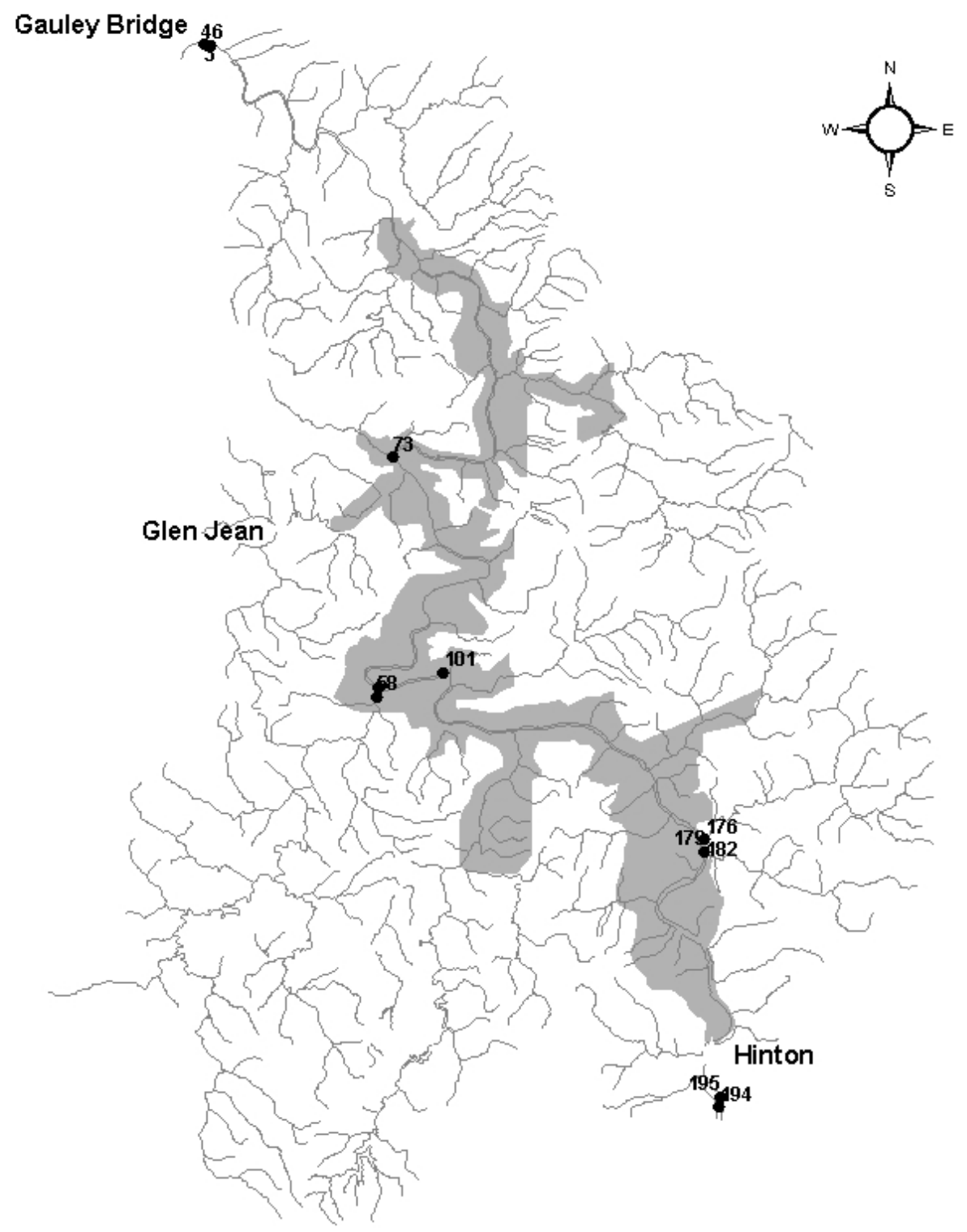

- Luxilus chrysocephalus

New River and tributaries

NRGNR boundary

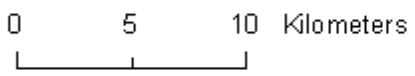

Figure 14. Collection sites for Luxilus chrysocphalus (striped shiner) within and near the New River Gorge National River. 


\section{Nocomis platyrhynchus (bigmouth chub)}

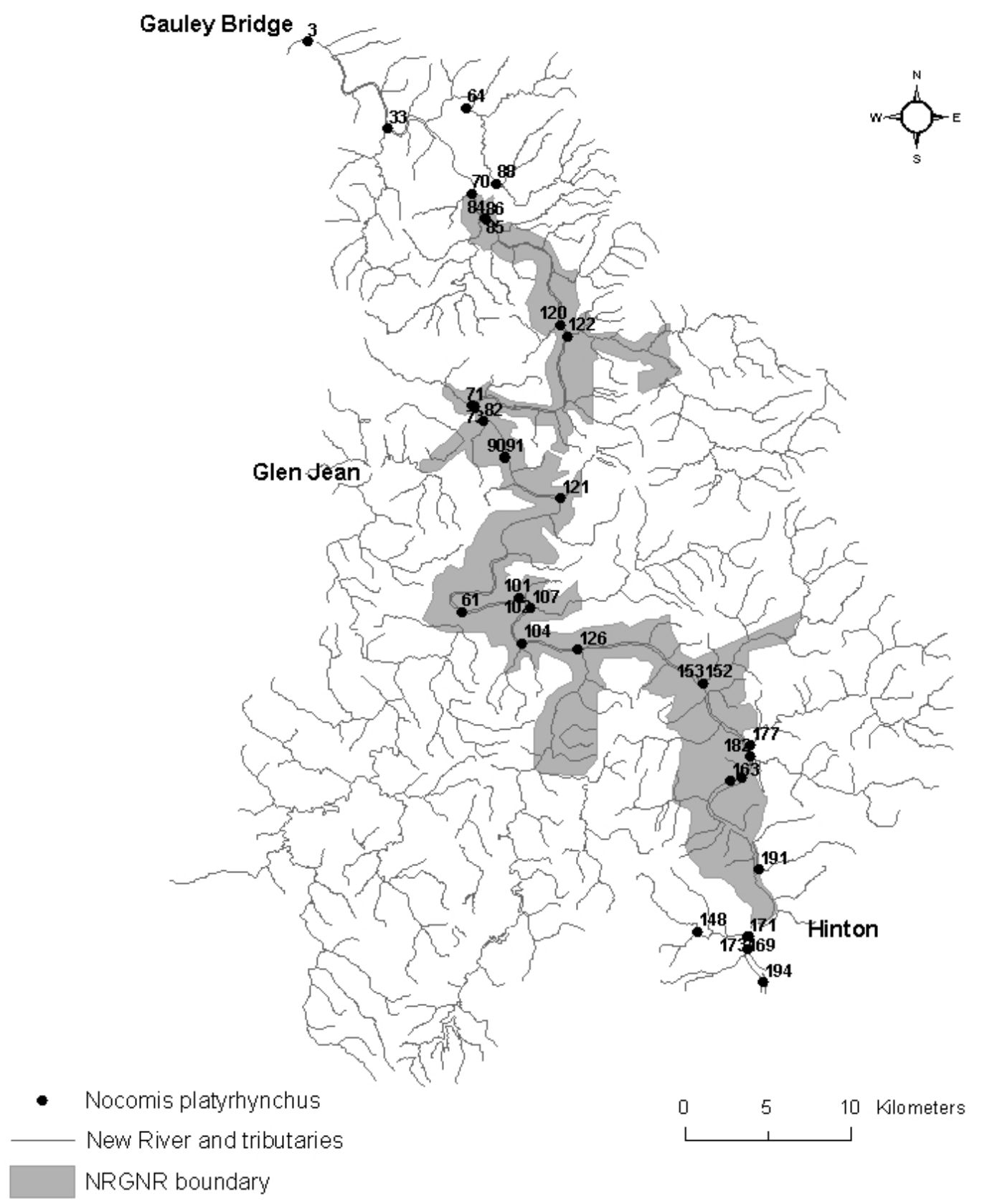

Figure 15. Collection sites for Nocomis platyrhynchus (bigmouth chub) within and near the New River Gorge National River. 


\section{Notemigonus crysoleucas (golden shiner)}

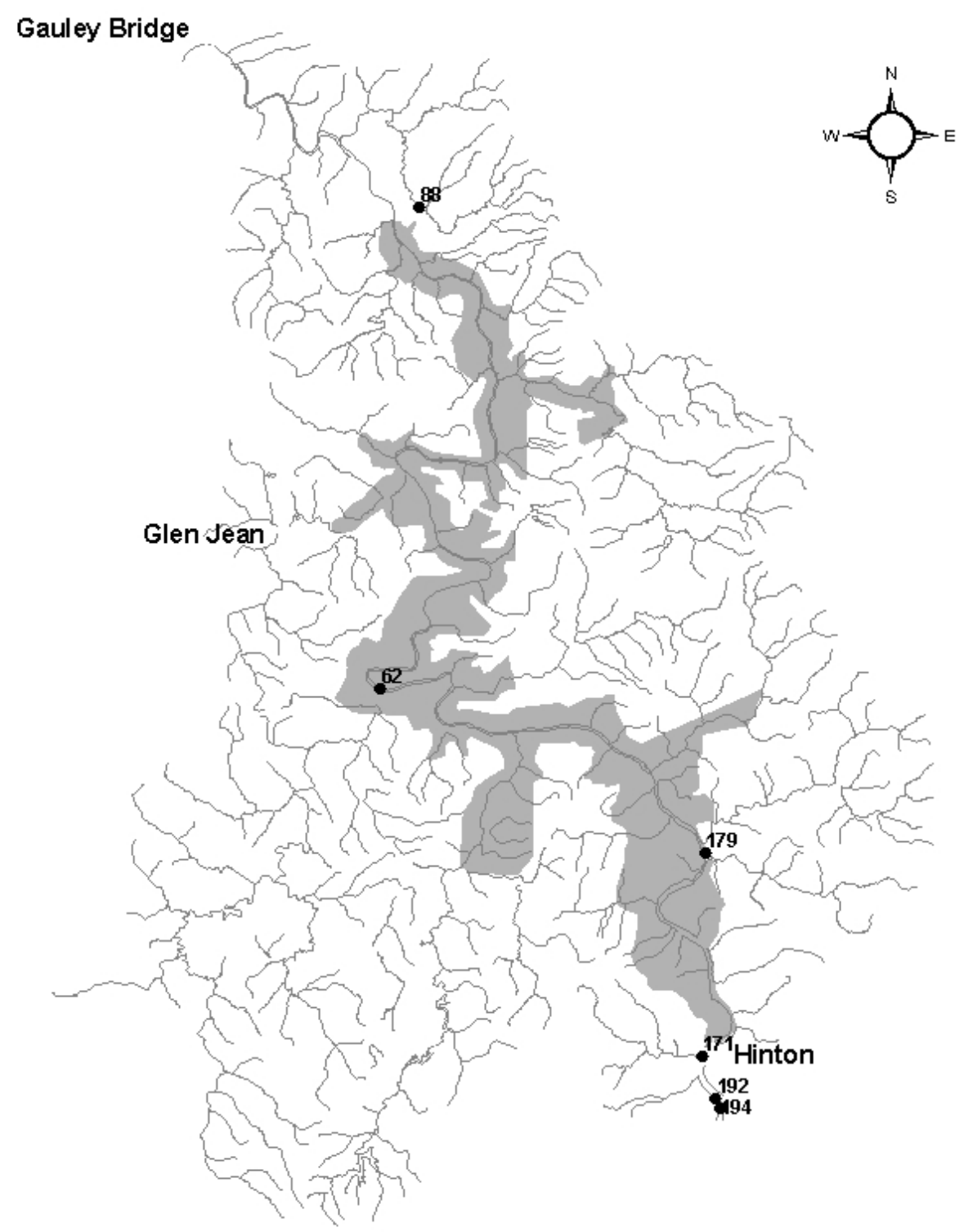

- Notemigonous crysoleucas

New River and tributaries

NRGNR boundary

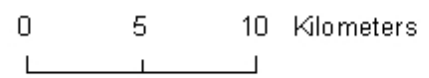

Figure 16. Collection sites for Notemigonus crysoleucas (golden shiner) within and near the New River Gorge National River. 


\section{Notropis hudsonius (spottail shiner)}

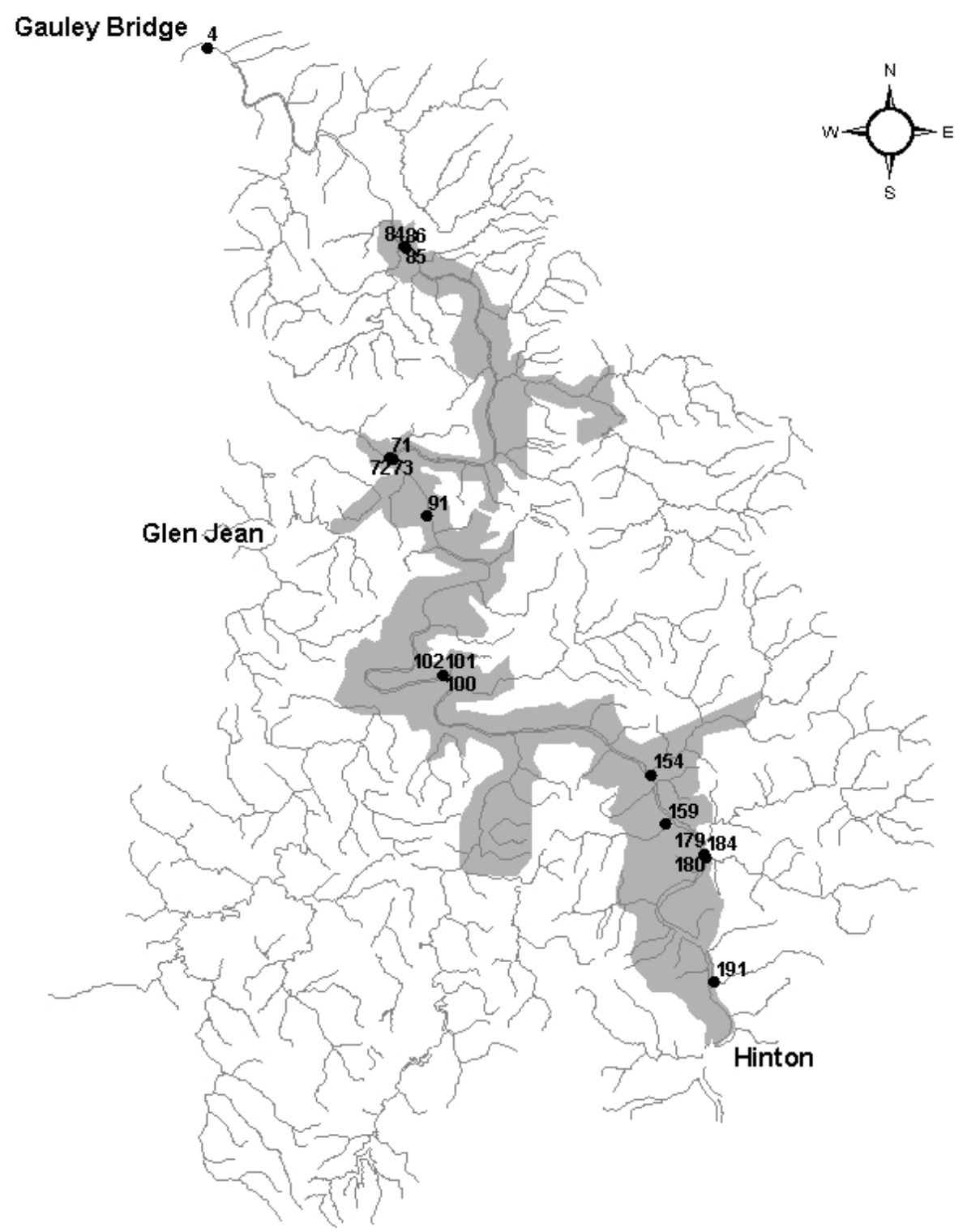

- Notropis hudsonius

New River and tributaries

NRGNR boundary

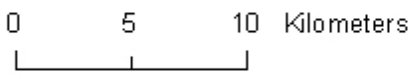

Figure 17. Collection sites for Notropis hudsonius (spottail shiner) within and near the New River Gorge National River. 


\section{Notropis photogenis (silver shiner)}

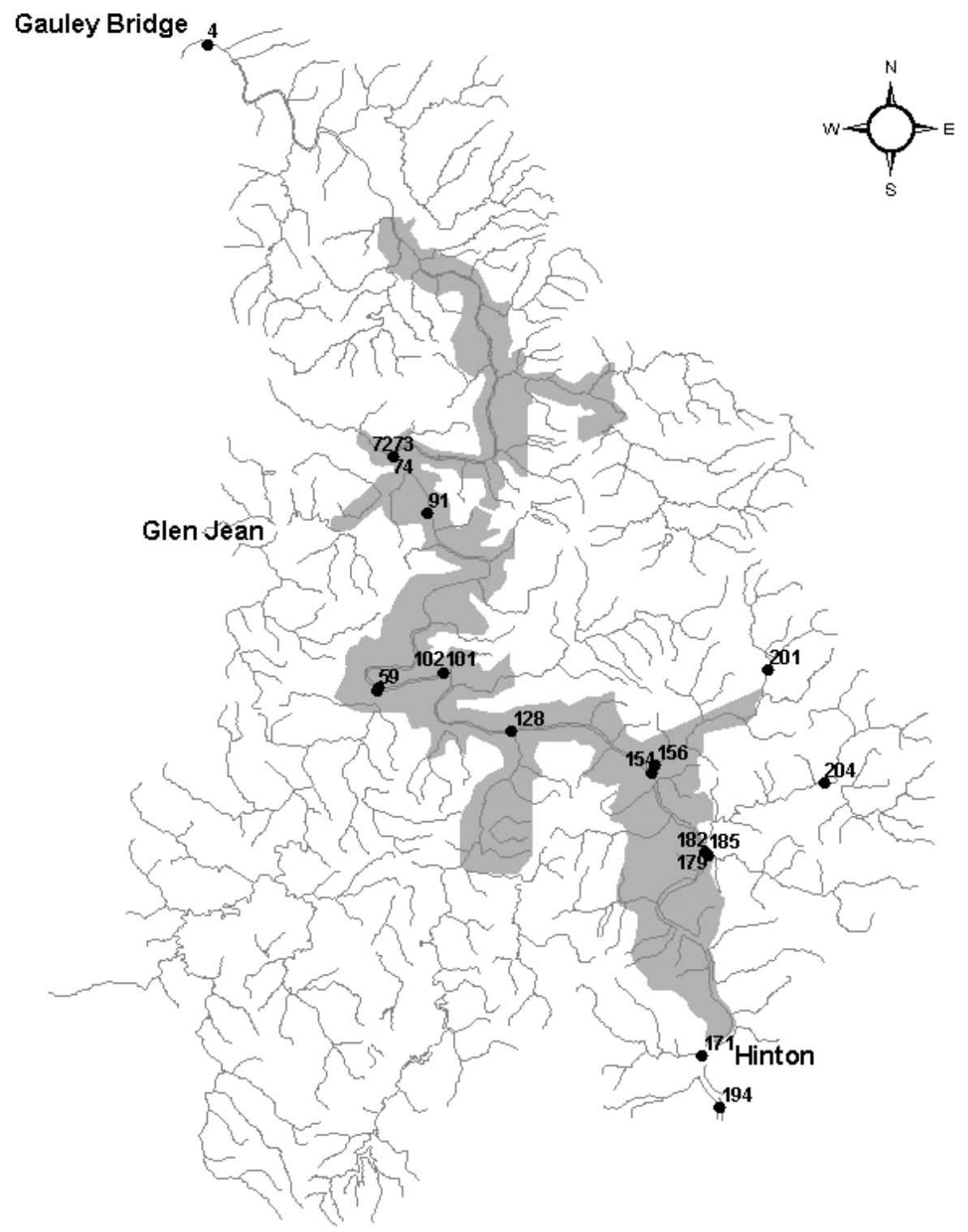

- Notropis photogenis

New River and tributaries

NRGNR boundary

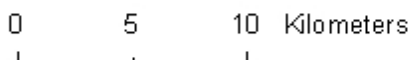

Figure 18. Collection sites for Notropis photogenis (silver shiner) within and near the New River Gorge National River. 


\section{Notropis rubellus (rosyface shiner)}

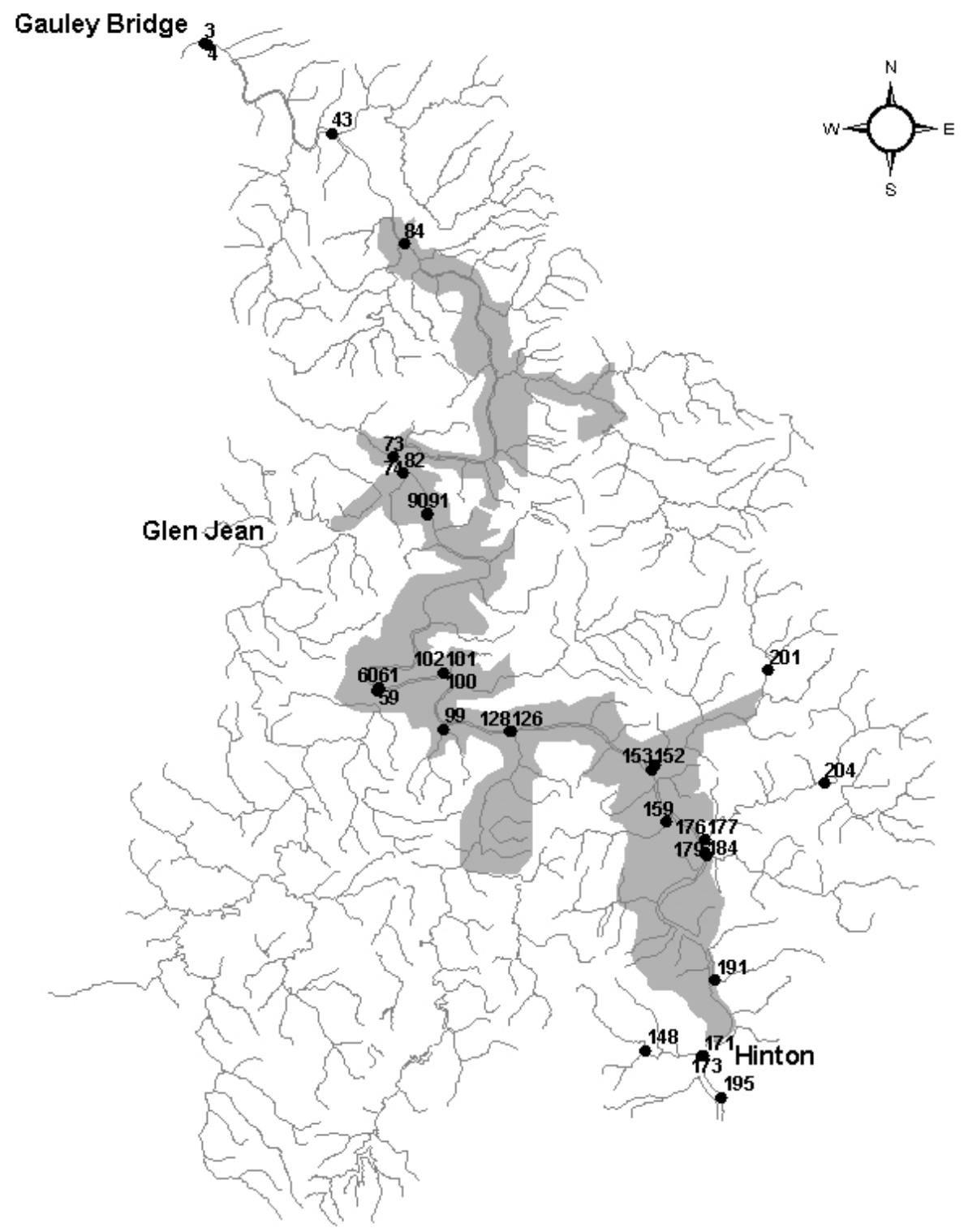

- Notropis rubellus

New River and tributaries

NRGNR boundary

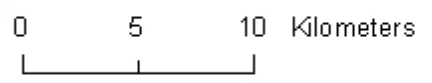

Figure 19. Collection sites for Notropis rubellus (rosyface shiner) within and near the New River Gorge National River. 


\section{Notropis scabriceps (New River shiner)}

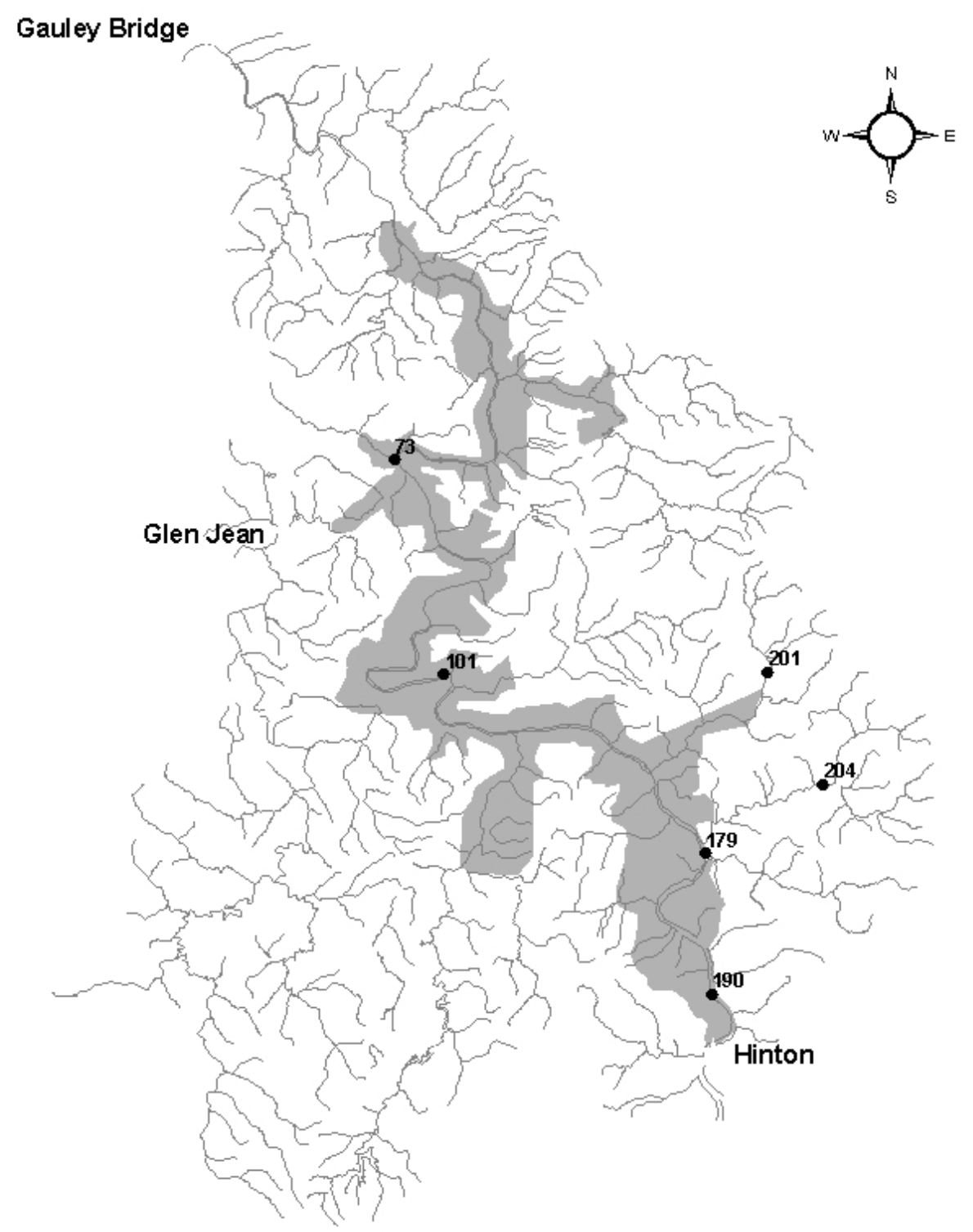

- Notropis scabriceps New River and tributaries NRGNR boundary

Figure 20. Collection sites for Notropis scabriceps (New River shiner) within and near the New River Gorge National River. 


\section{Notropis stramineus (sand shiner)}

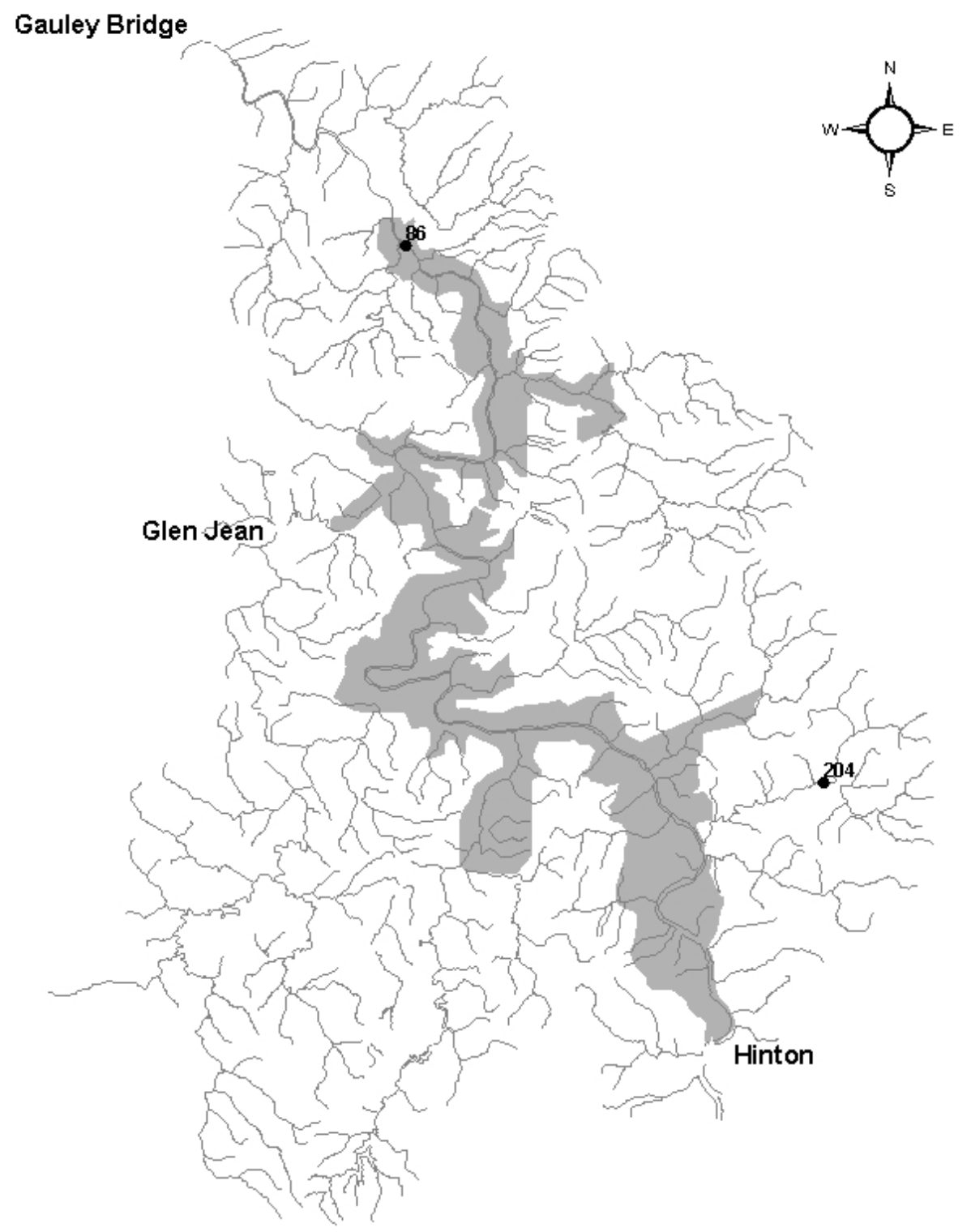

- Notropis stramineus

New River and tributaries

NRGNR boundary

Figure 21. Collection sites for Notropis stramineus (sand shiner) within and near the New River Gorge National River. 


\section{Notropis telescopus (telescope shiner)}

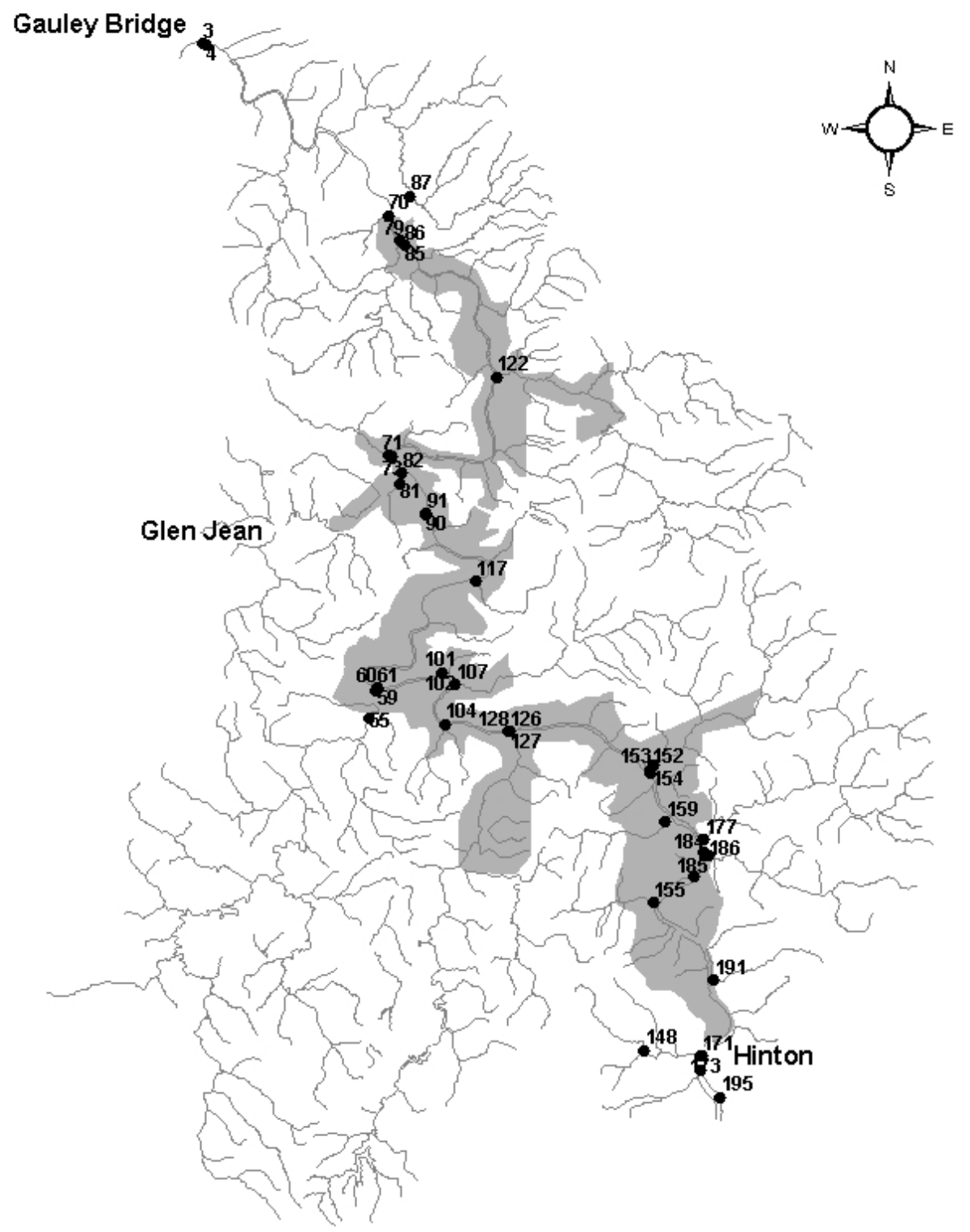

- Notropis telescopus

New River and tributaries

NRGNR boundary

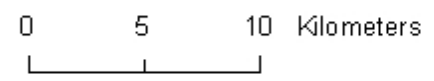

Figure 22. Collection sites for Notropis telescopus (telescope shiner) within and near the New River Gorge National River. 


\section{Notropis volucellus (mimic shiner)}

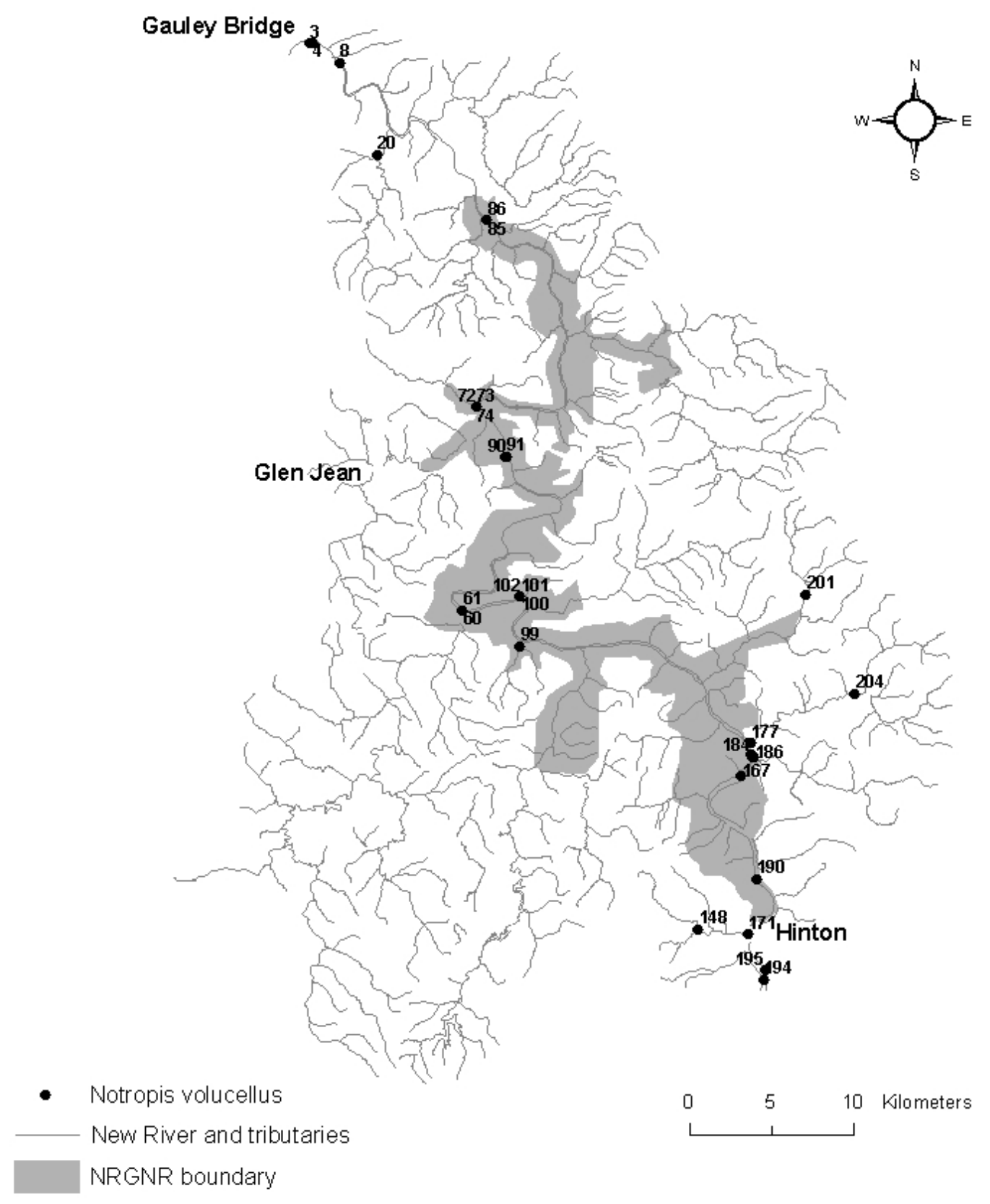

Figure 23. Collection sites for Notropis volucellus (mimic shiner) within and near the New River Gorge National River. 


\section{Phoxinus oreas (mountain redbelly dace)}

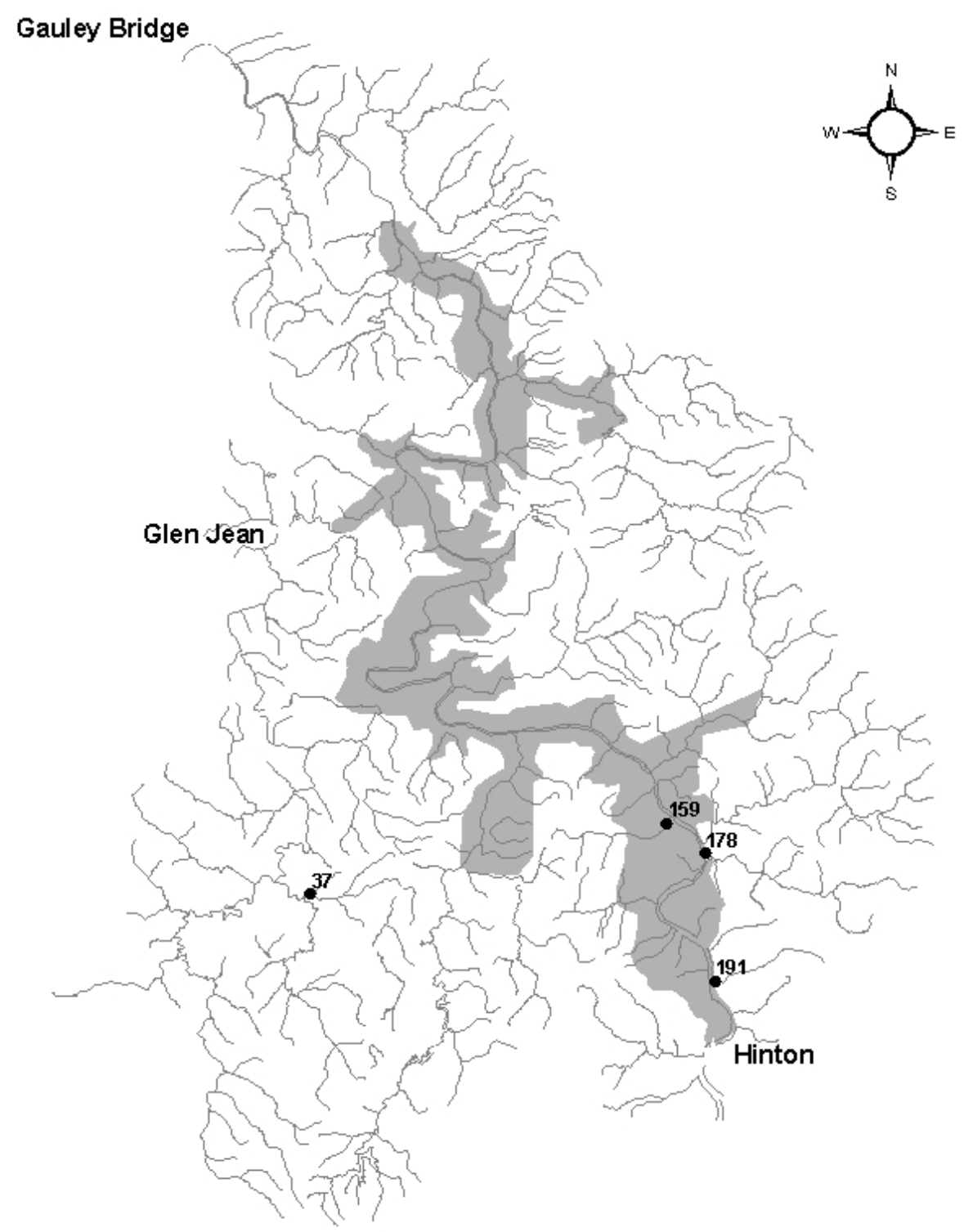

- Phoxinus oreas

New River and tributaries

NRGNR boundary

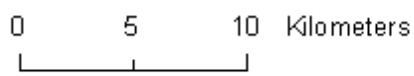

Figure 24. Collection sites for Phoxinus oreas (mountain redbelly dace) within and near the New River Gorge National River. 


\section{Pimephales notatus (bluntnose minnow)}

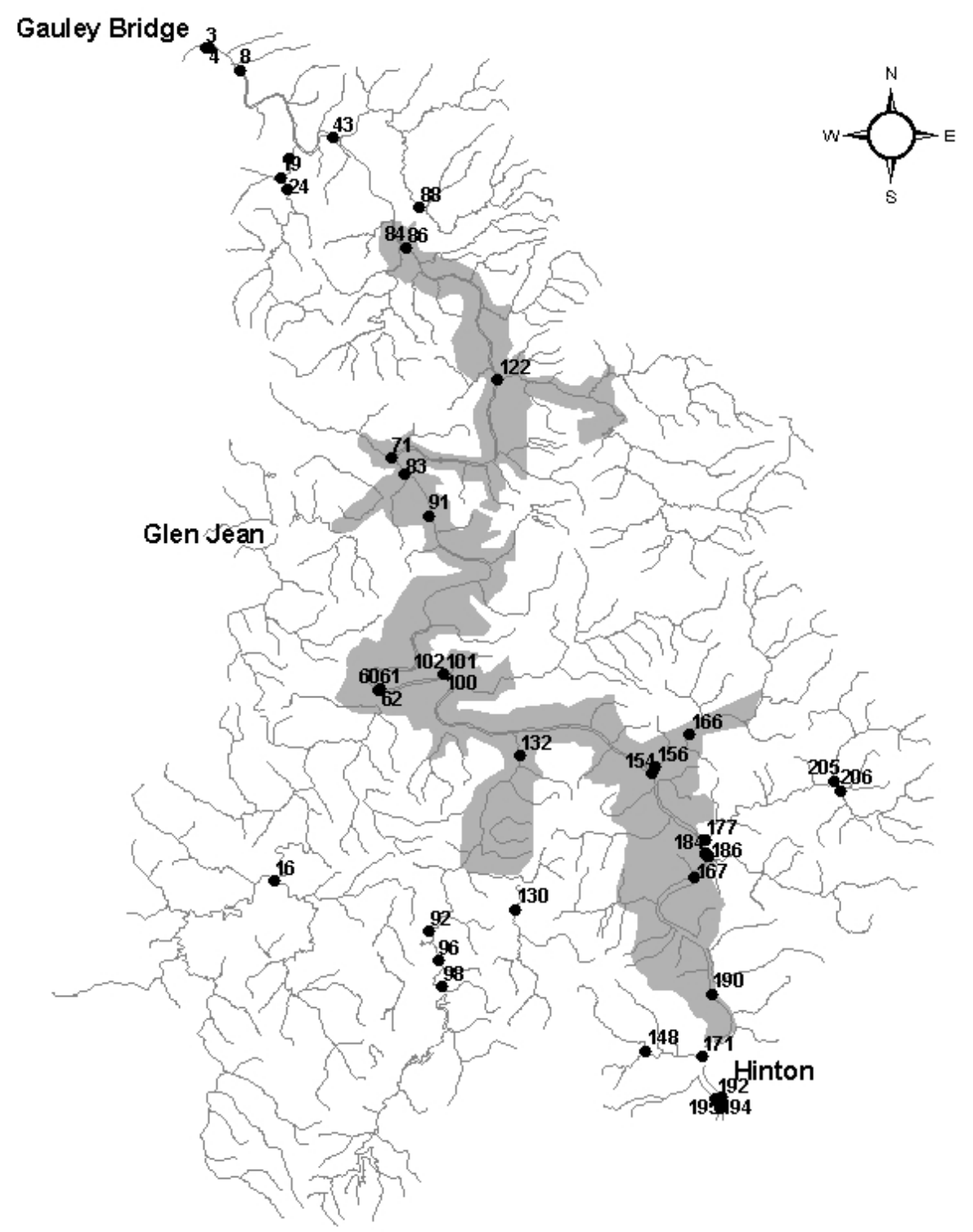

- Pimephales notatus New River and tributaries NRGNR boundary

Figure 25. Collection sites for Pimephales notatus (bluntnose minnow) within and near the New River Gorge National River. 


\section{Pimephales promelas (fathead minnow)}

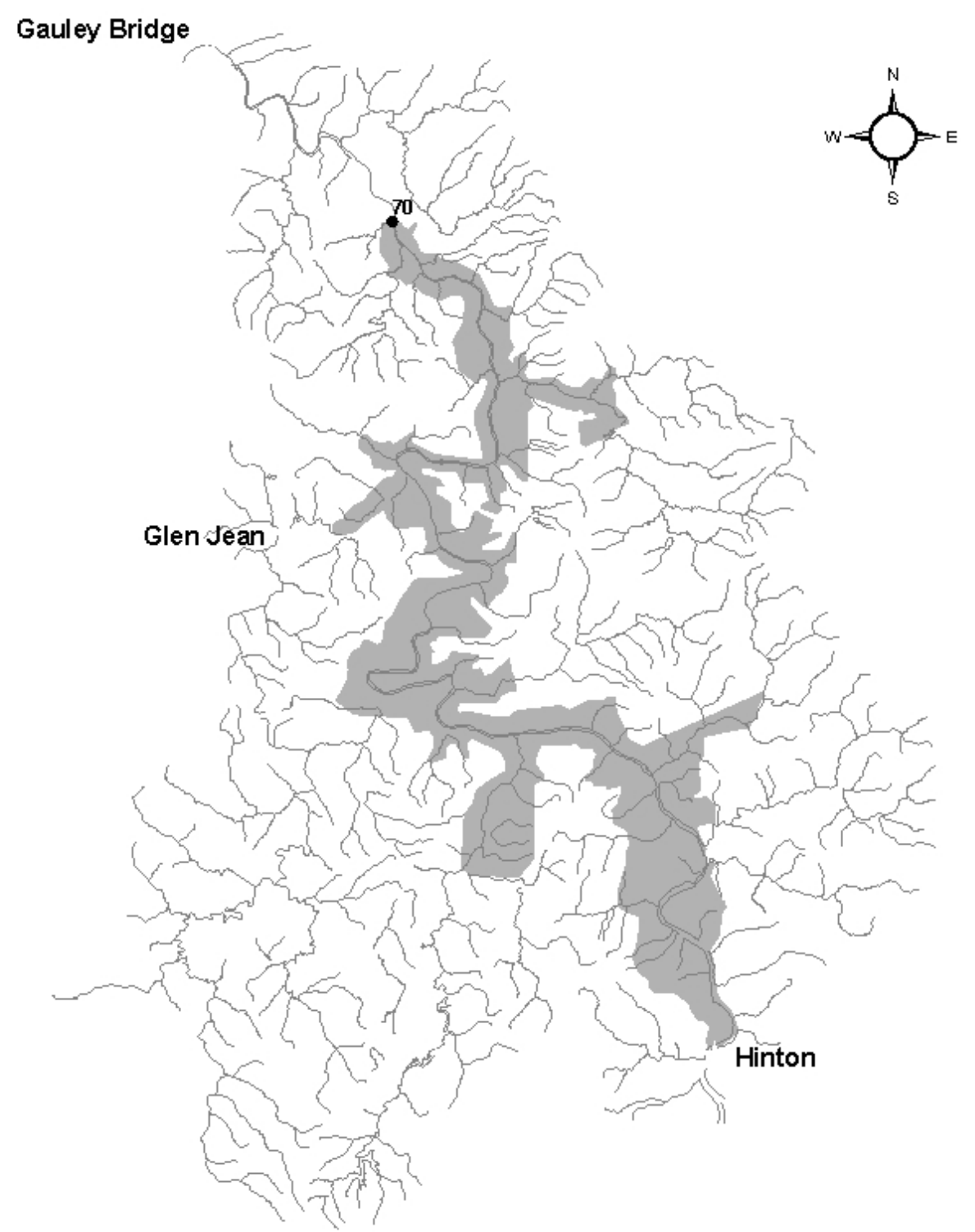

- Pimephales promelas

New River and tributaries

NRGNR boundary

$0 \quad 5 \quad 10$ Klometers

Figure 26. Collection site for Pimephales promelas (fathead minnow) within the New River Gorge National River. 


\section{Rhinichthys atratulus (blacknose dace)}

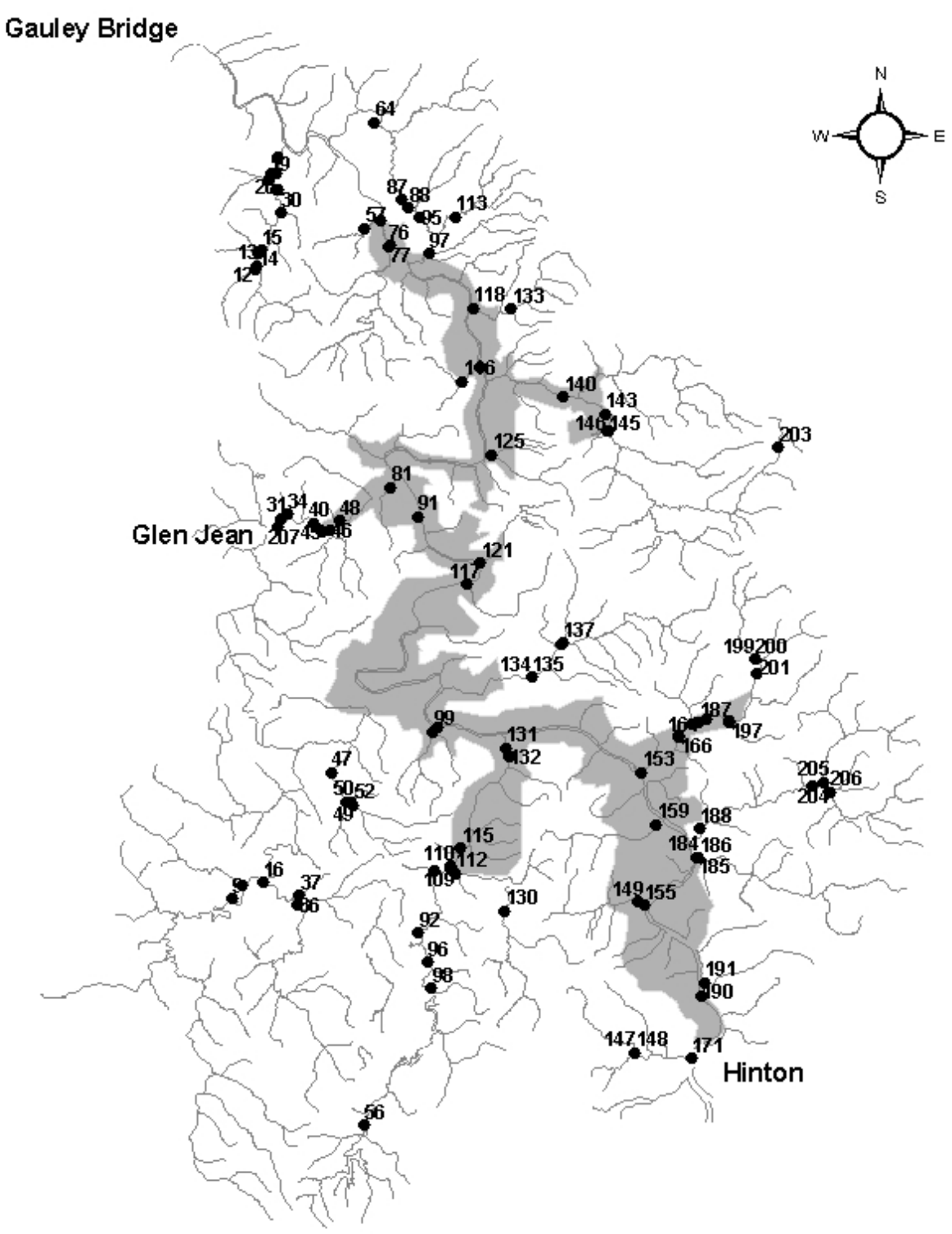

- Rhinichthys atratulus

New River and tributaries

NRGNR boundary

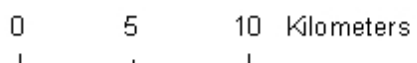

Figure 27. Collection sites for Rhinichthys atratulus (blacknose dace) within and near the New River Gorge National River. 


\section{Rhinichthys cataractae (longnose dace)}

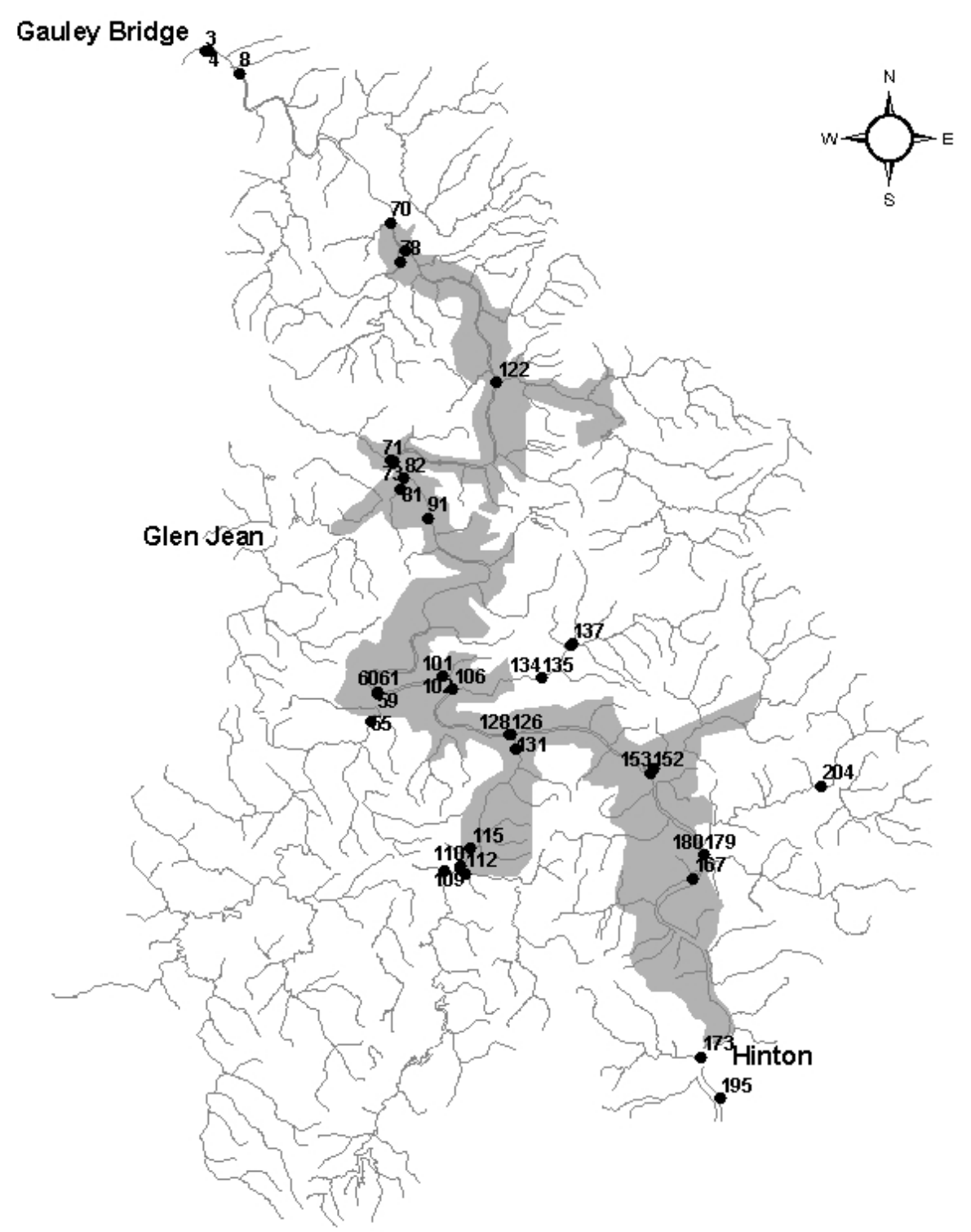

- Rhinichthys cataractae

New River and tributaries

NRGNR boundary

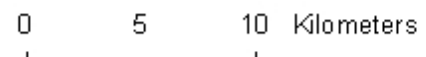

Figure 28. Collection sites for Rhinichthys cataractae (longnose dace) within or near the New River Gorge National River. 


\section{Semotilus atromaculatus (creek chub)}

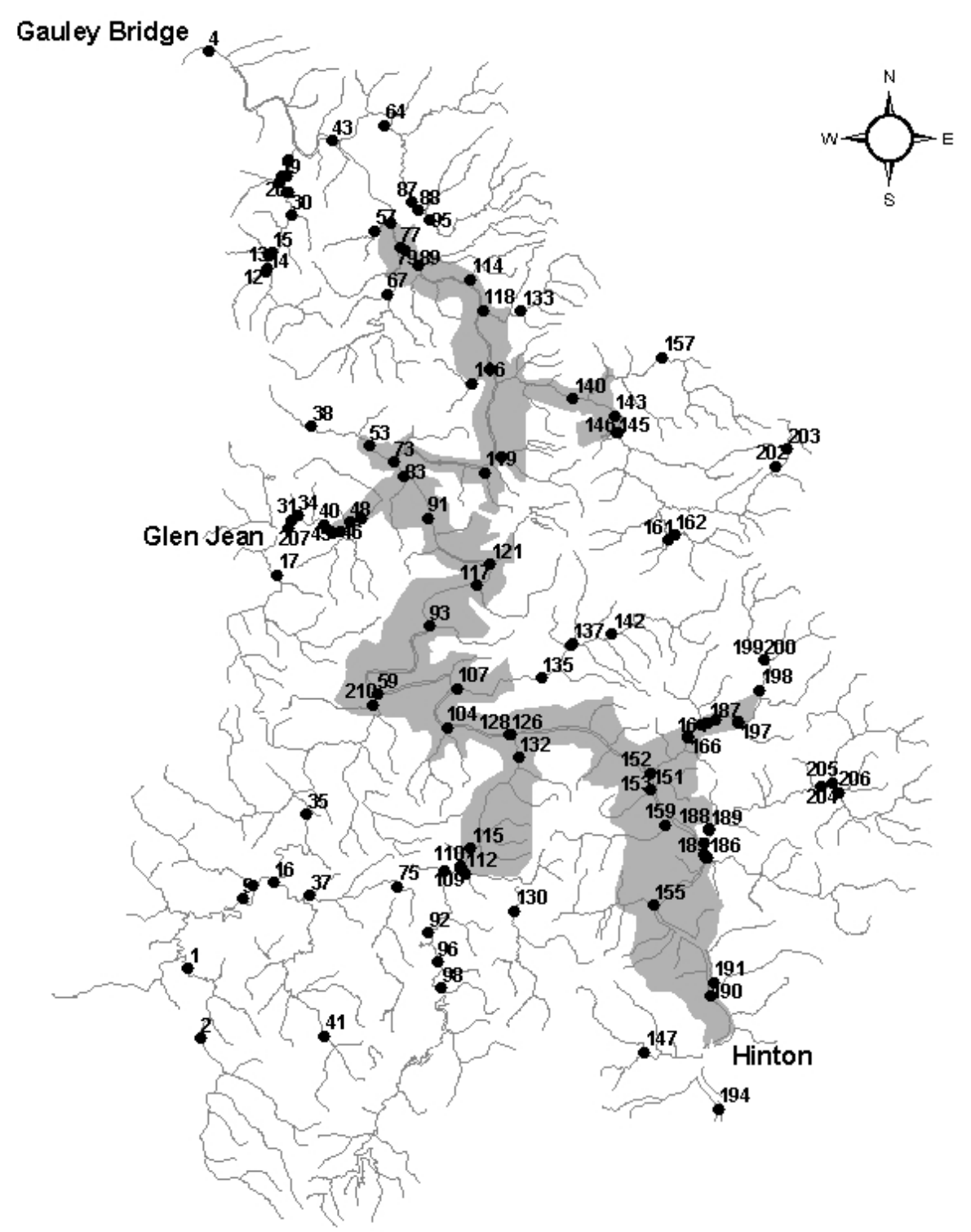

- Semotilus atromaculatus

New River and tributaries

NRGNR boundary

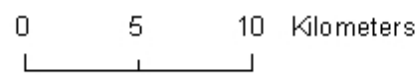

Figure 29. Collection sites for Semotilus atromaculatus (creek chub) within and near the New River Gorge National River. 


\section{Catostomus commersoni (white sucker)}

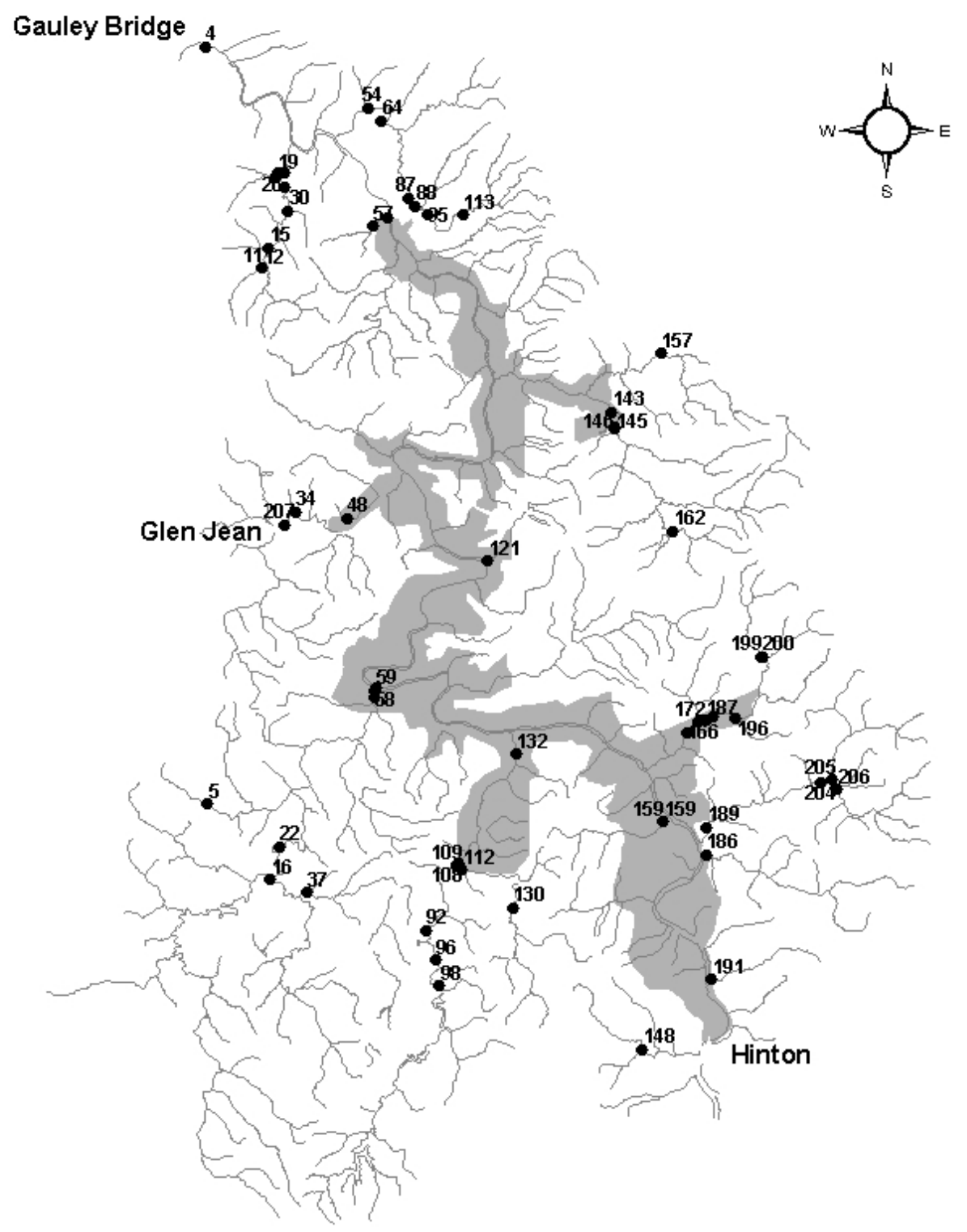

- Catostomus commersoni

New River and tributaries

NRGNR boundary

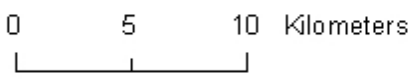

Figure 30. Collection sites for Catostomus commersoni (white sucker) within and near the New River Gorge National River. 


\section{Hypentelium nigricans (northern hogsucker)}

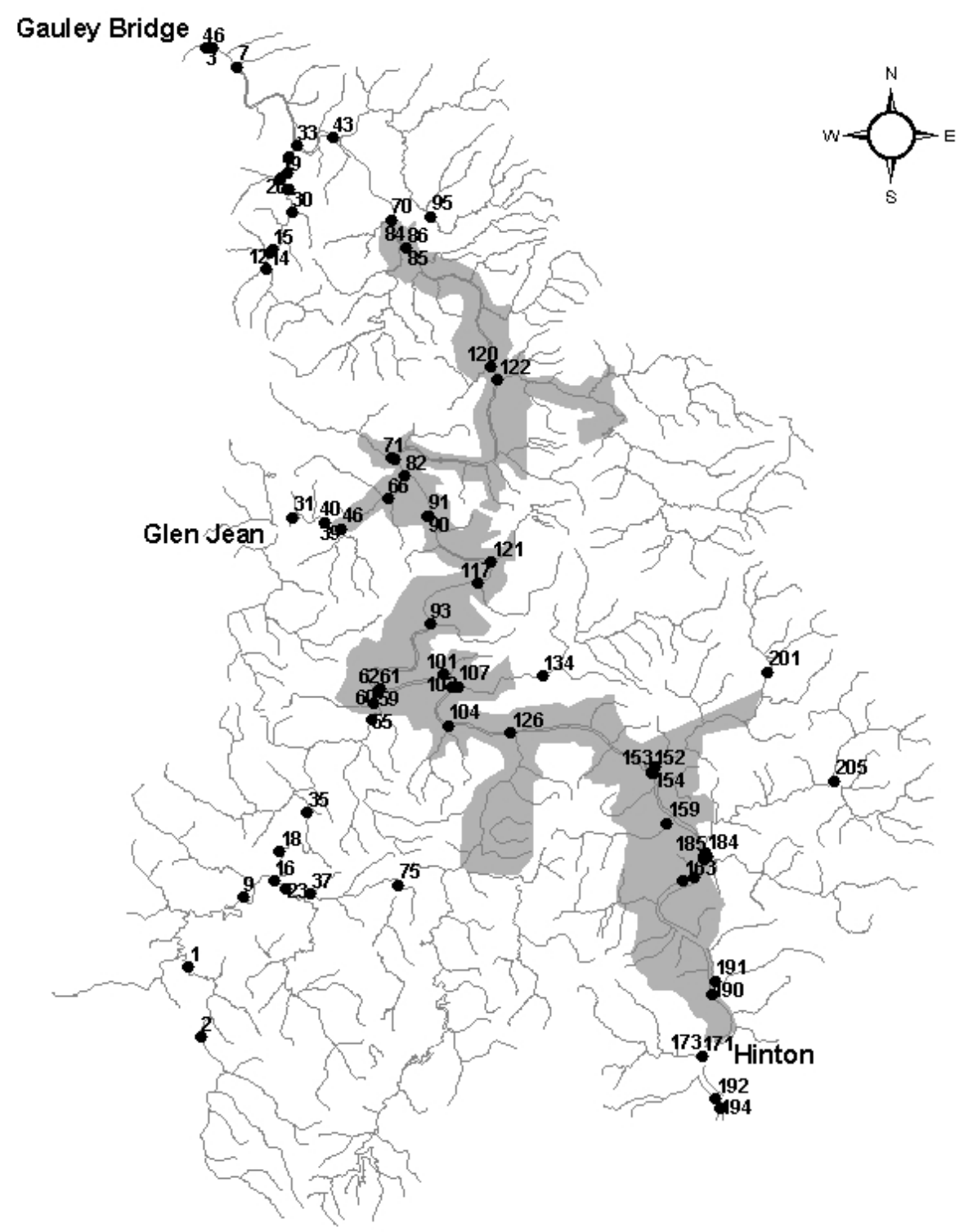

- Hypentelium nigricans

New River and tributaries

NRGNR boundary

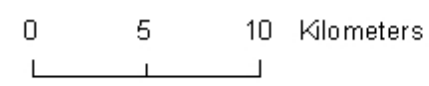

Figure 31. Collection sites for Hypentelium nigricans (northern hogsucker) within and near the New River Gorge National River. 


\section{Ameiurus natalis (yellow bullhead)}

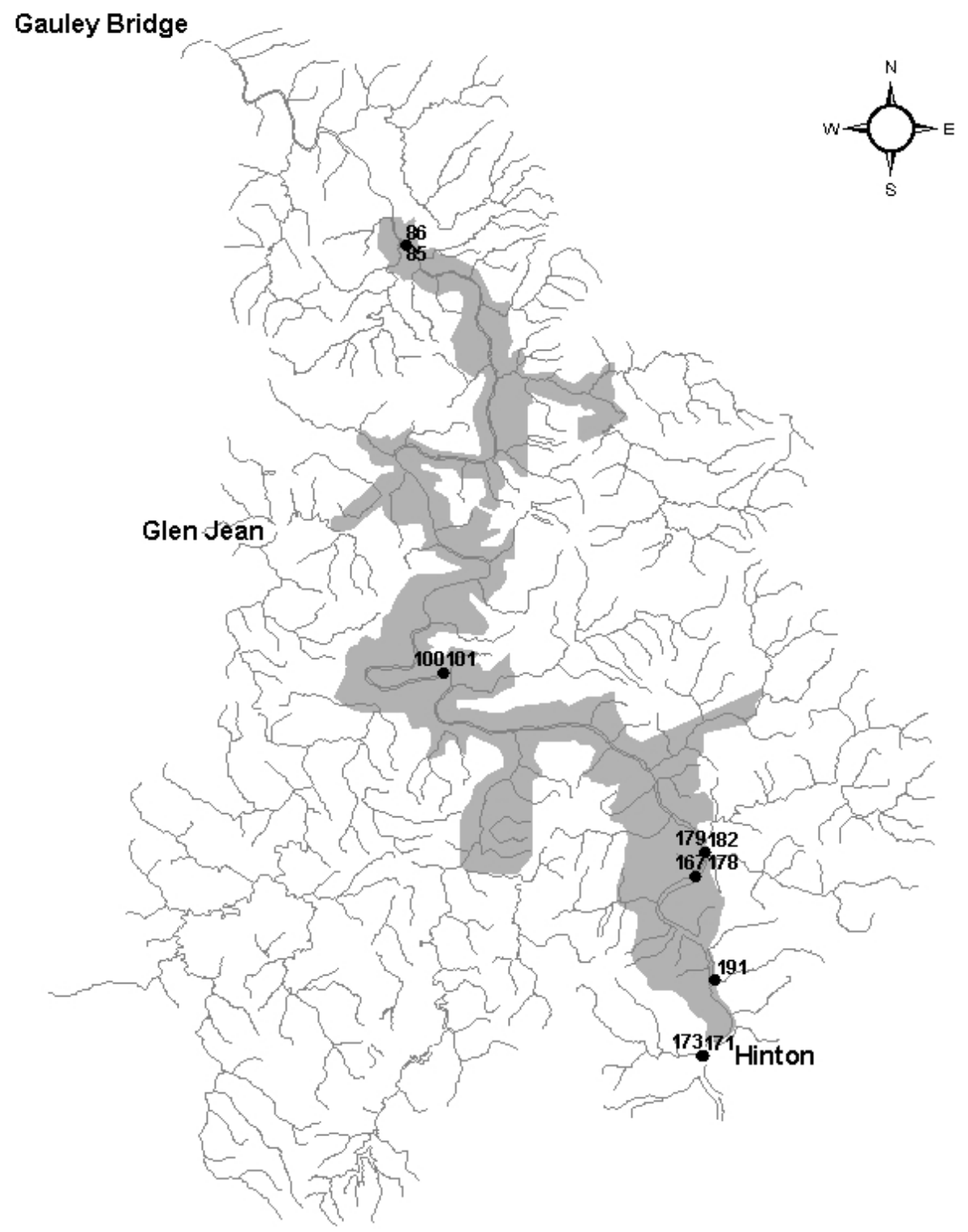

- Ameiurus natalis

New River and tributaries

NRGNR boundary

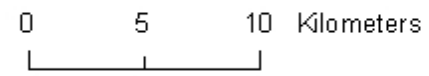

Figure 32. Collection sites for Ameiurus natalis (yellow bullhead) within and near the New River Gorge National River. 


\section{Ictalurus punctatus (channel catfish)}

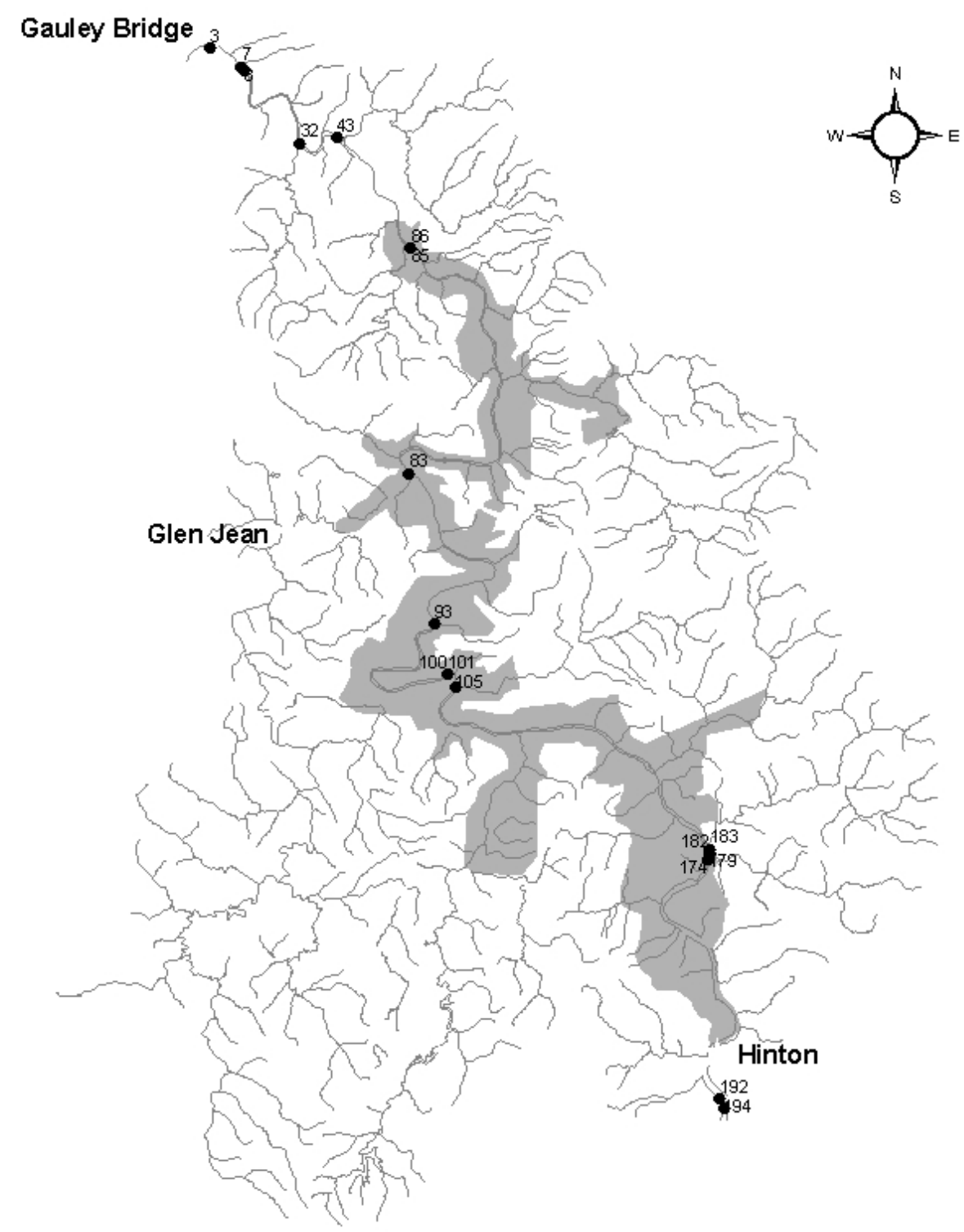

- Ictalurus punctatus

New River and tributaries

NRGNR boundary

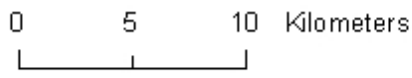

Figure 33. Collection sites for Ictalurus punctatus (channel catfish) within and near the New River Gorge National River. 


\section{Pylodictis olivaris (flathead catfish)}

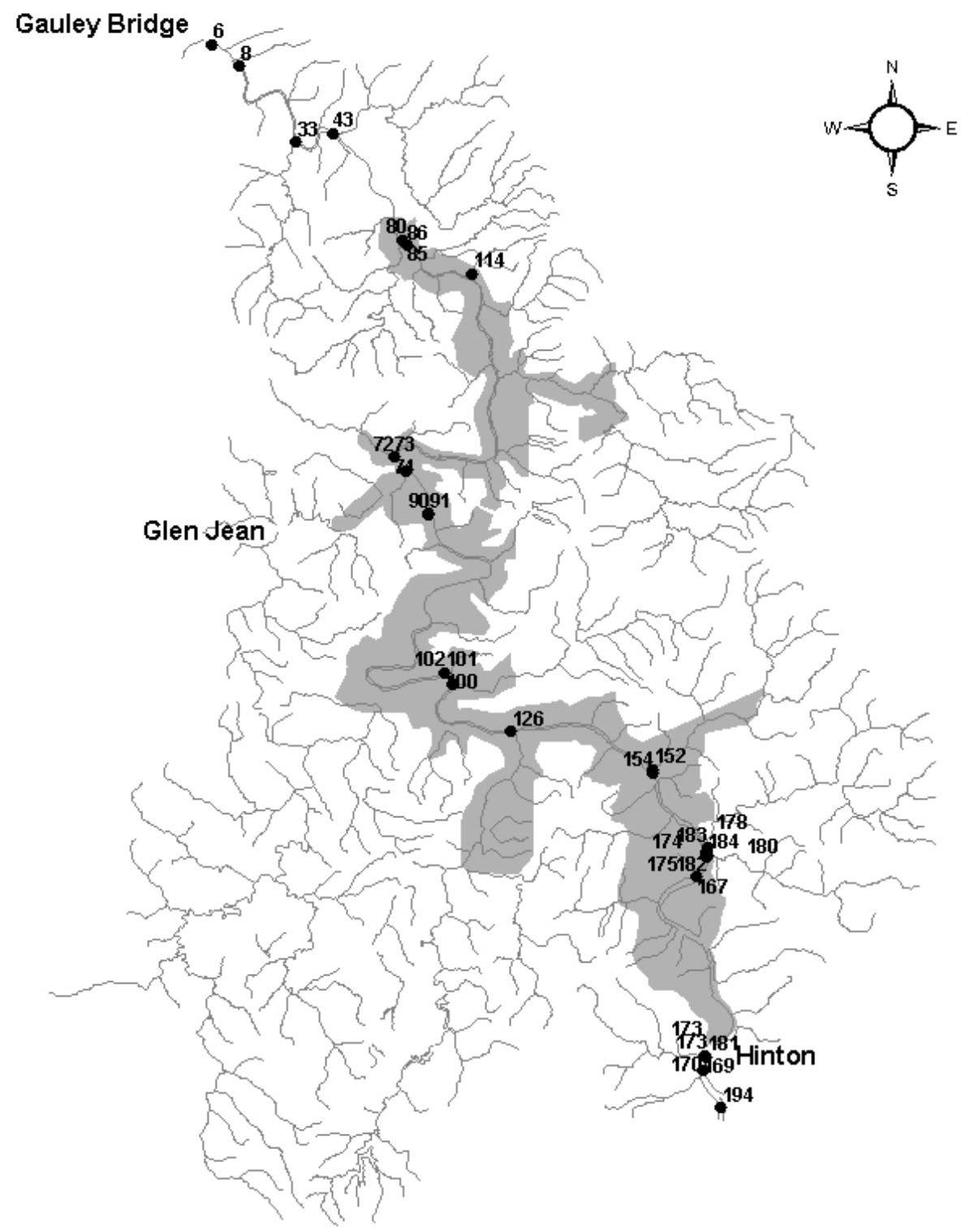

- Pylodictis olivaris

New River and tributaries

NRGNR boundary

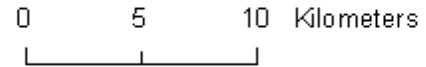

Figure 34. Collection sites for Pylodictis olivaris (flathead catfish) within and near the New River Gorge National River. 


\section{Labidesthes sicculus (brook silverside)}

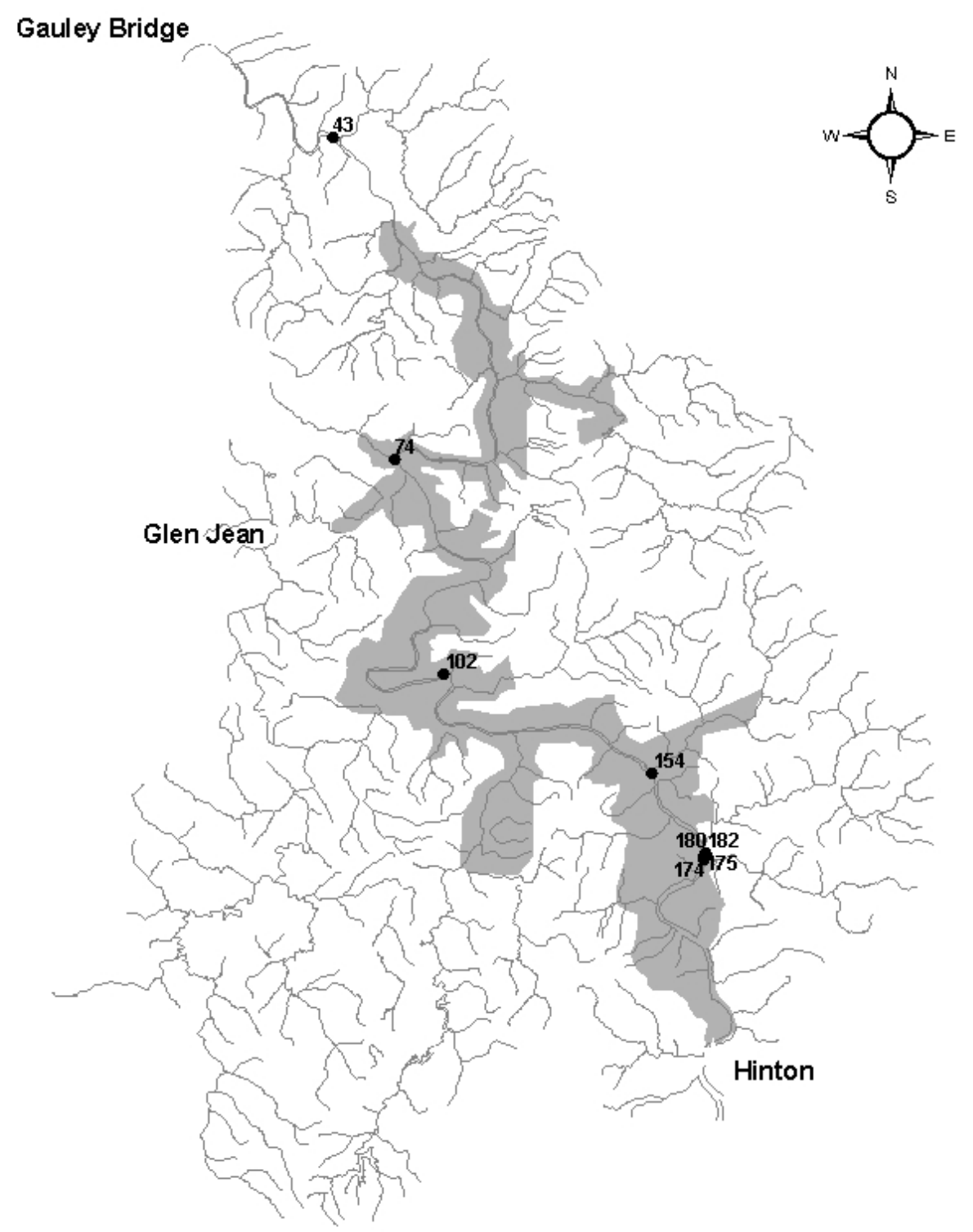

- Labidesthes sicculus

New River and tributaries

NRGNR boundary

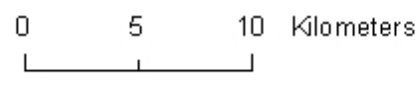

Figure 35. Collection sites for Labidesthes sicculus (brook silverside) within and near the New River Gorge National River. 


\section{Cottus bairdi (mottled sculpin)}

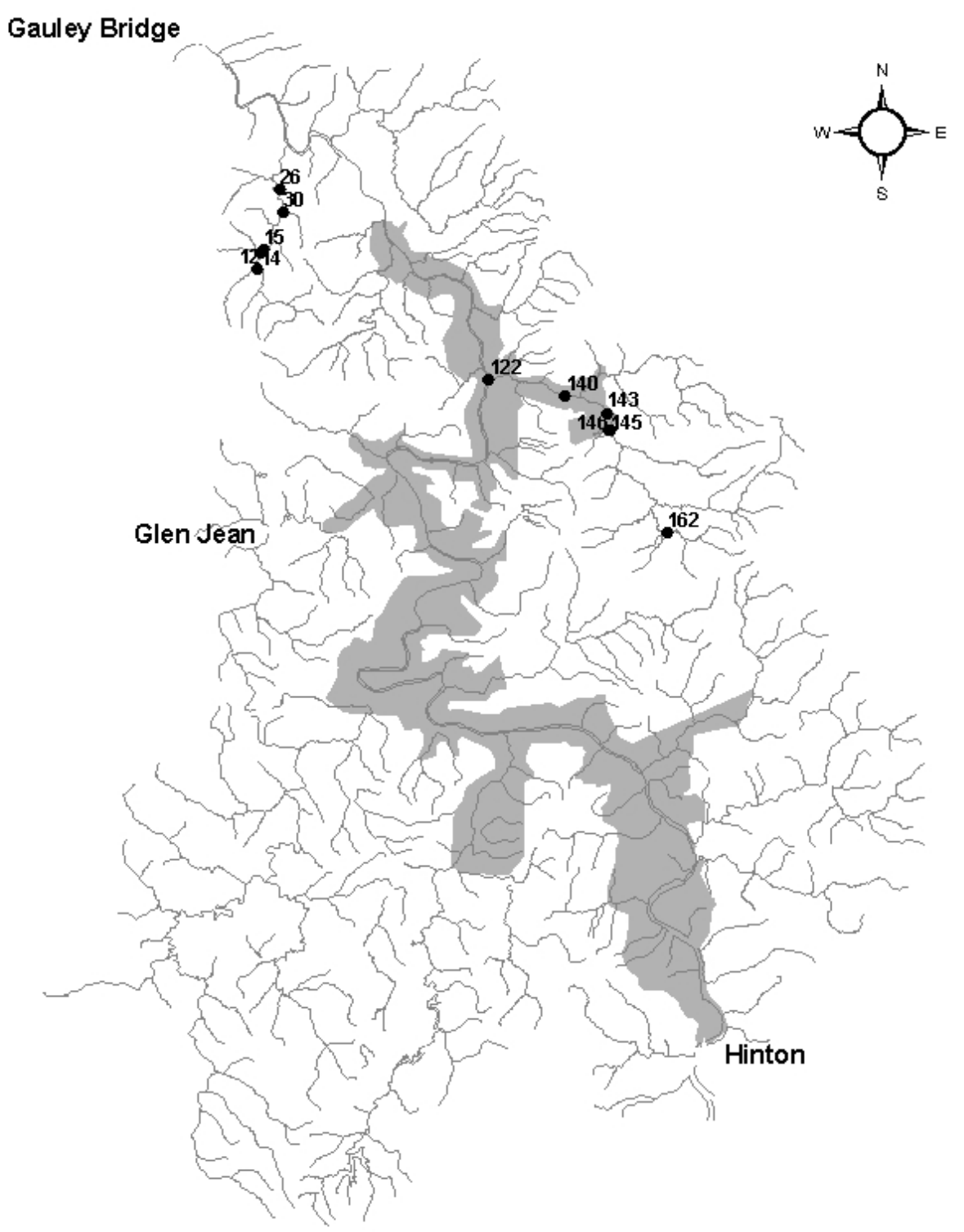

- Cottus bairdi

New River and tributaries

NRGNR boundary

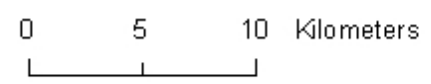

Figure 36. Collection sites for Cottus bairdi (mottled sculpin) within and near the New River Gorge National River. 


\section{Morone chrysops (white bass)}

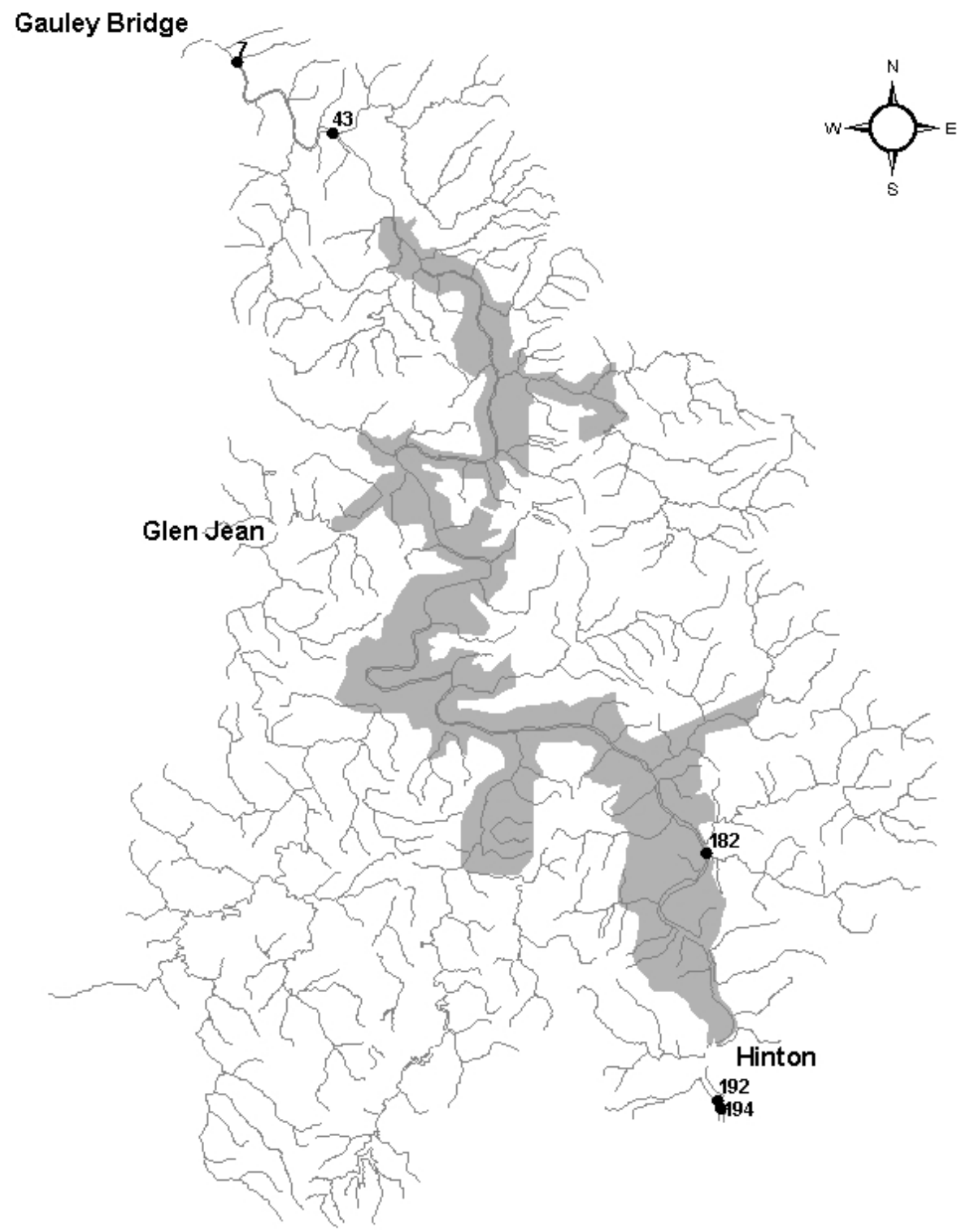

- Morone chrysops

New River and tributaries

NRGNR boundary

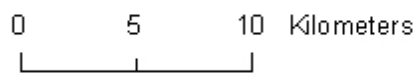

Figure 37. Collection sites for Morone chrysops (white bass) within and near the New River Gorge National River. 


\section{Oncorhynchus mykiss (rainbow trout)}

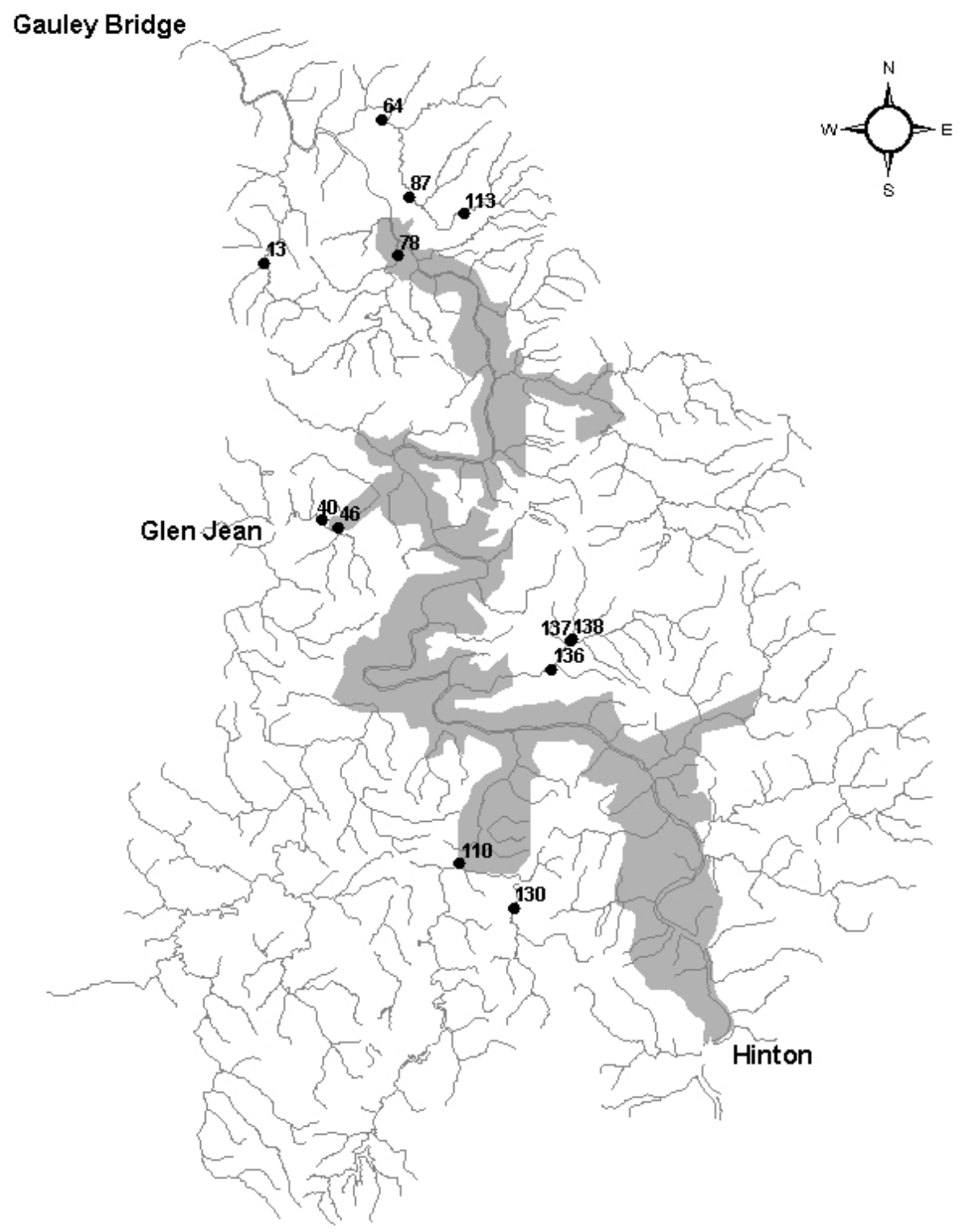

- Oncorhynchus mykiss

- New River and tributaries NRGNR boundary

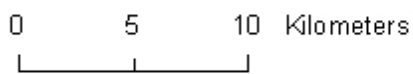

Figure 38. Collection sites for Oncorhynchus mykiss (rainbow trout) within and near the New River Gorge National River. 


\section{Salmo trutta (brown trout)}

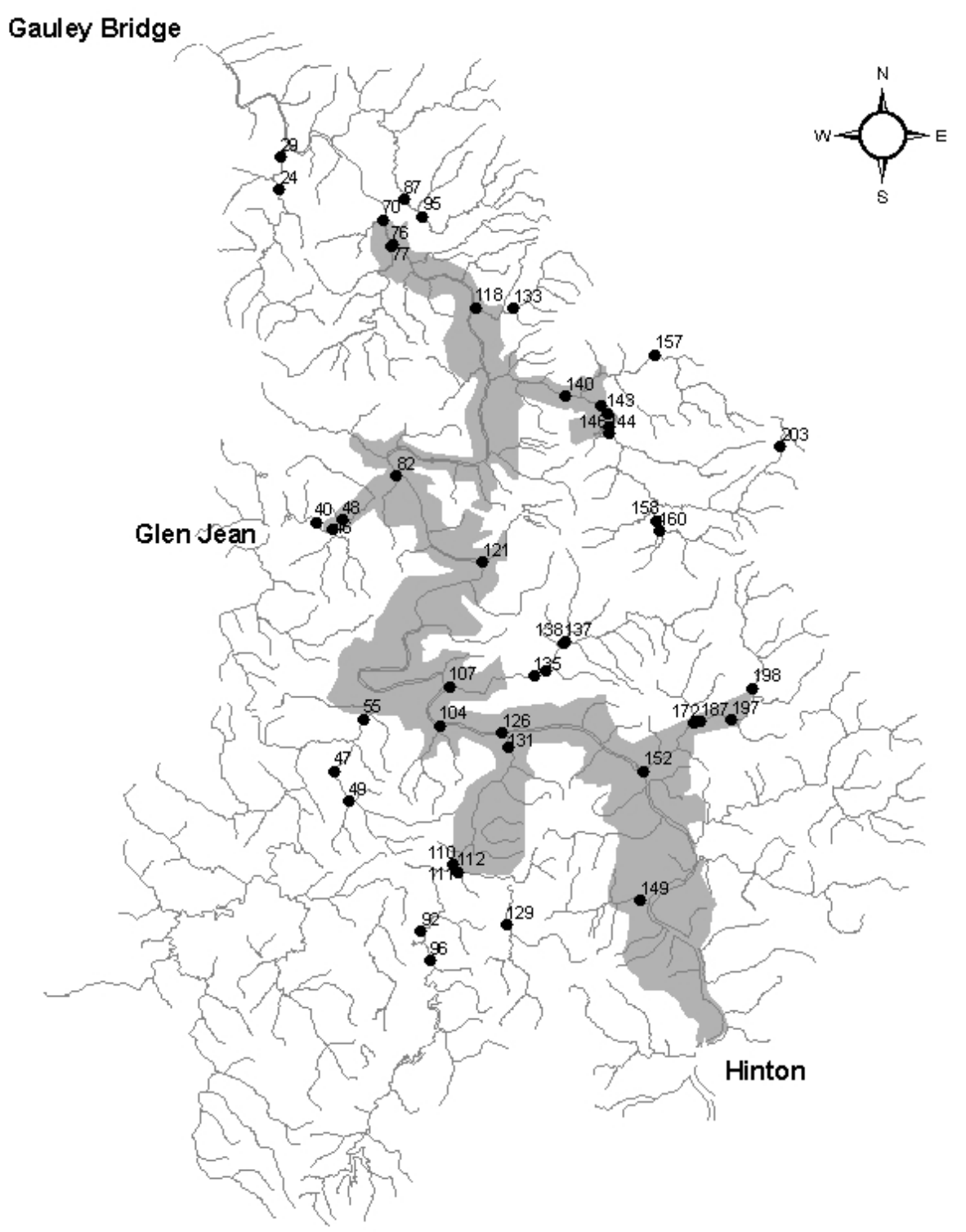

- Salmo trutta

New River and tributaries

NRGNR boundary

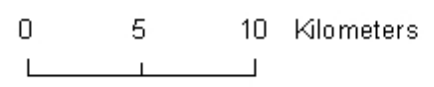

Figure 39. Collection sites for Salmo trutta (brown trout) within and near the New River Gorge National River. 


\section{Salvelinus fontinalis (brook trout)}

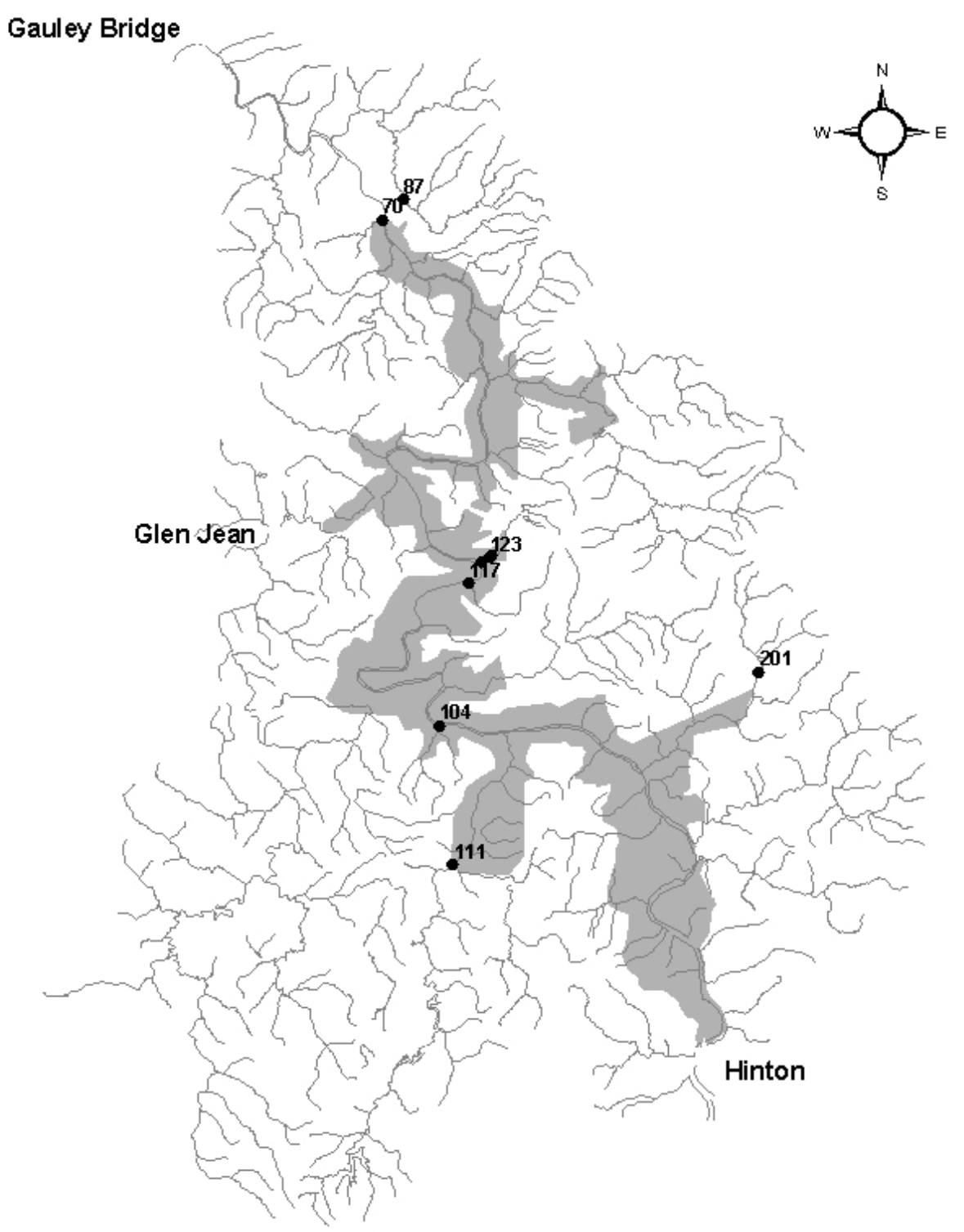

- Salvelinus fontinalis

New River and tributaries

NRGNR boundary

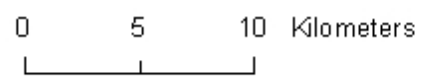

Figure 40. Collection sites for Salvelinus fontinalis (brook trout) within and near the New River Gorge National River. 


\section{Ambloplites rupestris (rock bass)}

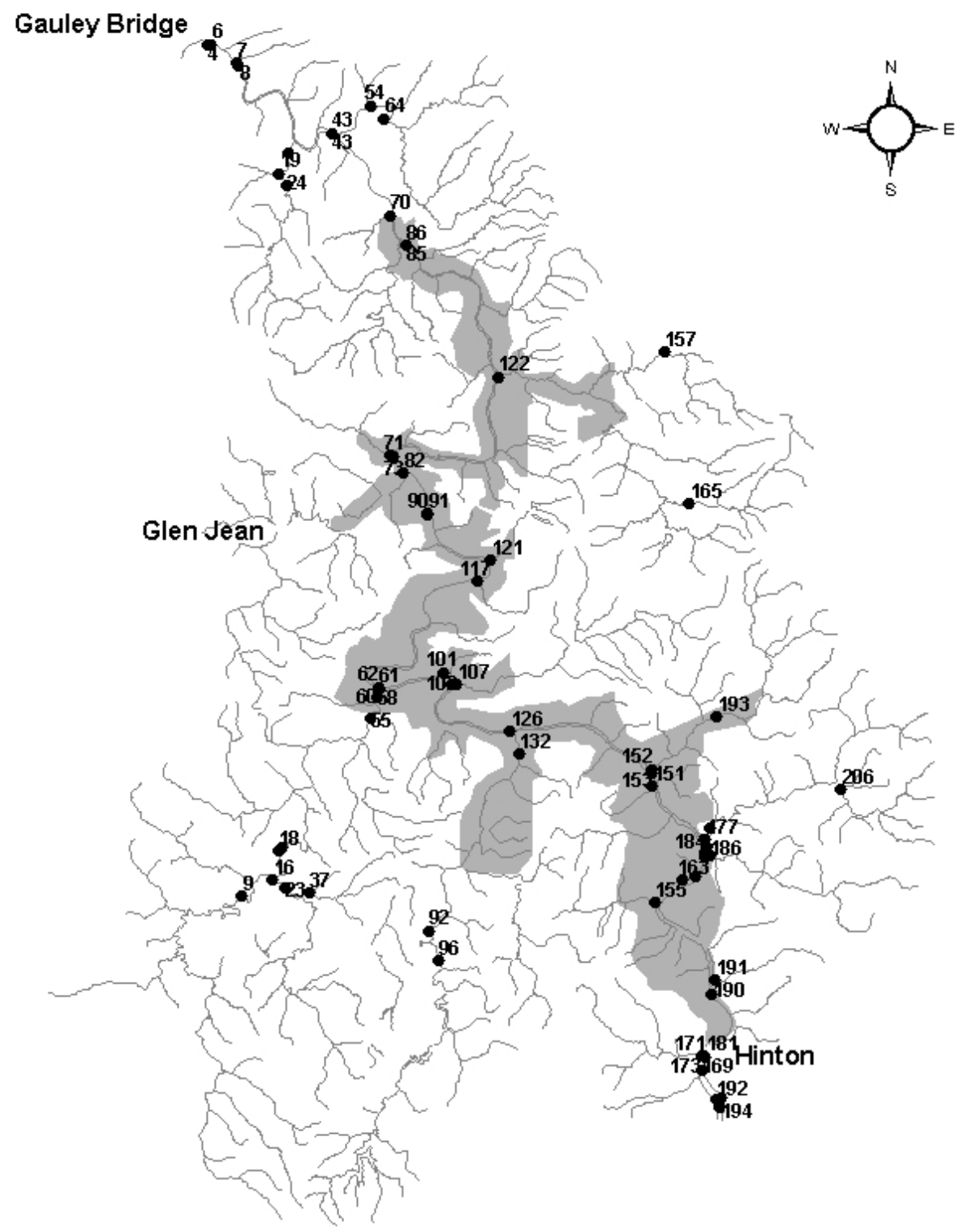

- Ambloplites rupestris

New River and tributaries

NRGNR boundary

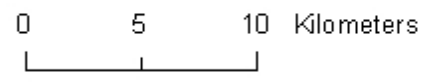

Figure 41. Collection sites for Ambloplites rupestris (rock bass) within and near the New River Gorge National River. 


\section{Lepomis auritus (redbreast sunfish)}

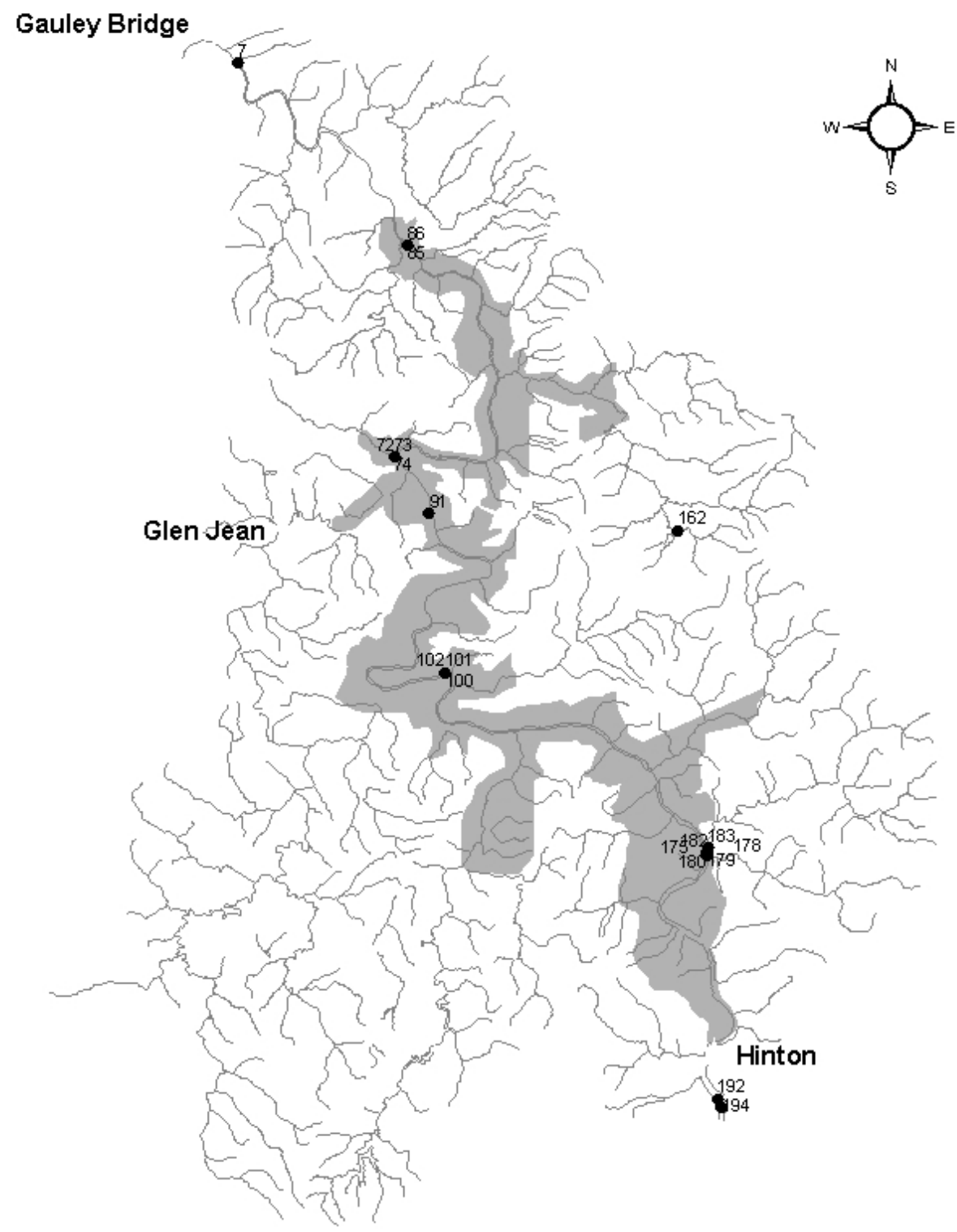

- Lepomis auritus

New River and tributaries

NRGNR boundary

Figure 42. Collection sites for Lepomis auritus (redbreast sunfish) within and near the New River Gorge National River. 


\section{Lepomis cyanellus (green sunfish)}

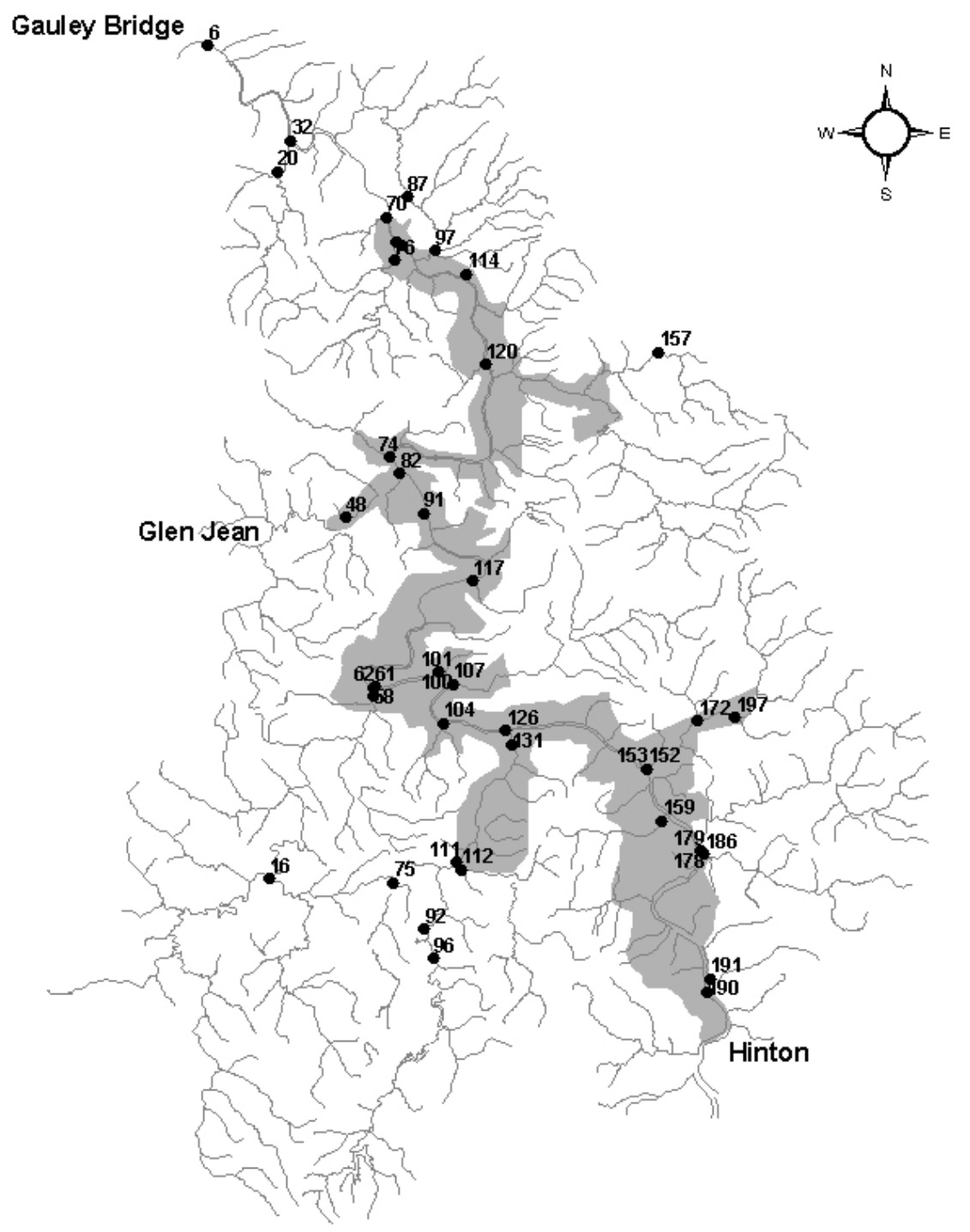

- Lepomis cyanellus

New River and tributaries

NRGNR boundary

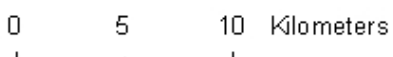

Figure 43. Collection sites for Lepomis cyanellus (green sunfish) within and near the New River Gorge National River 


\section{Lepomis gibbosus (pumpkinseed)}

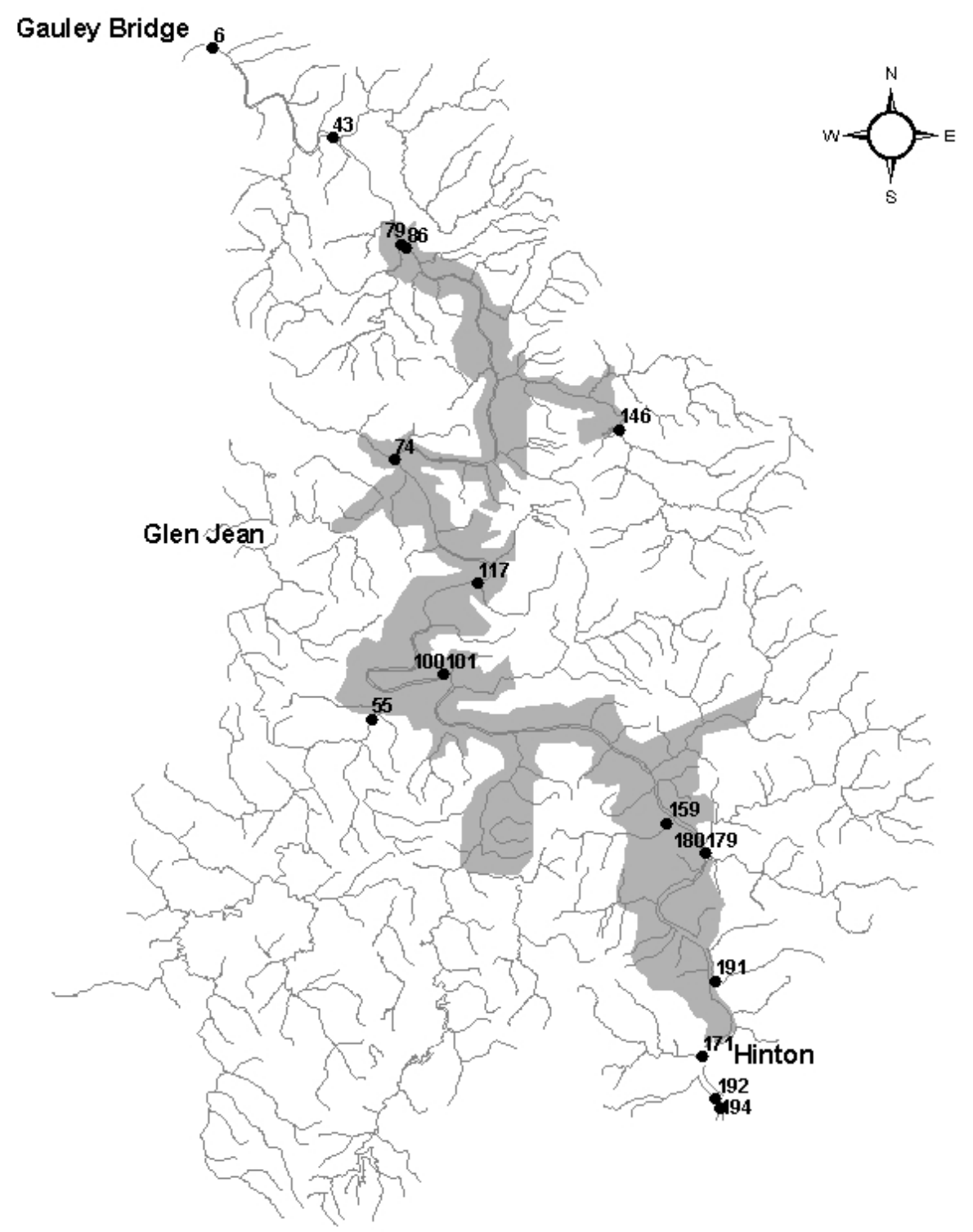

- Lepomis gibbosus

New River and tributaries

NRGNR boundary

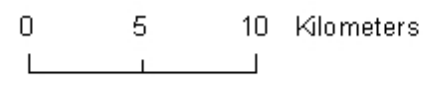

Figure 44. Collection sites for Lepomis gibbosus (pumpkinseed) within and near the New River Gorge National River. 


\section{Lepomis macrochirus (bluegill)}

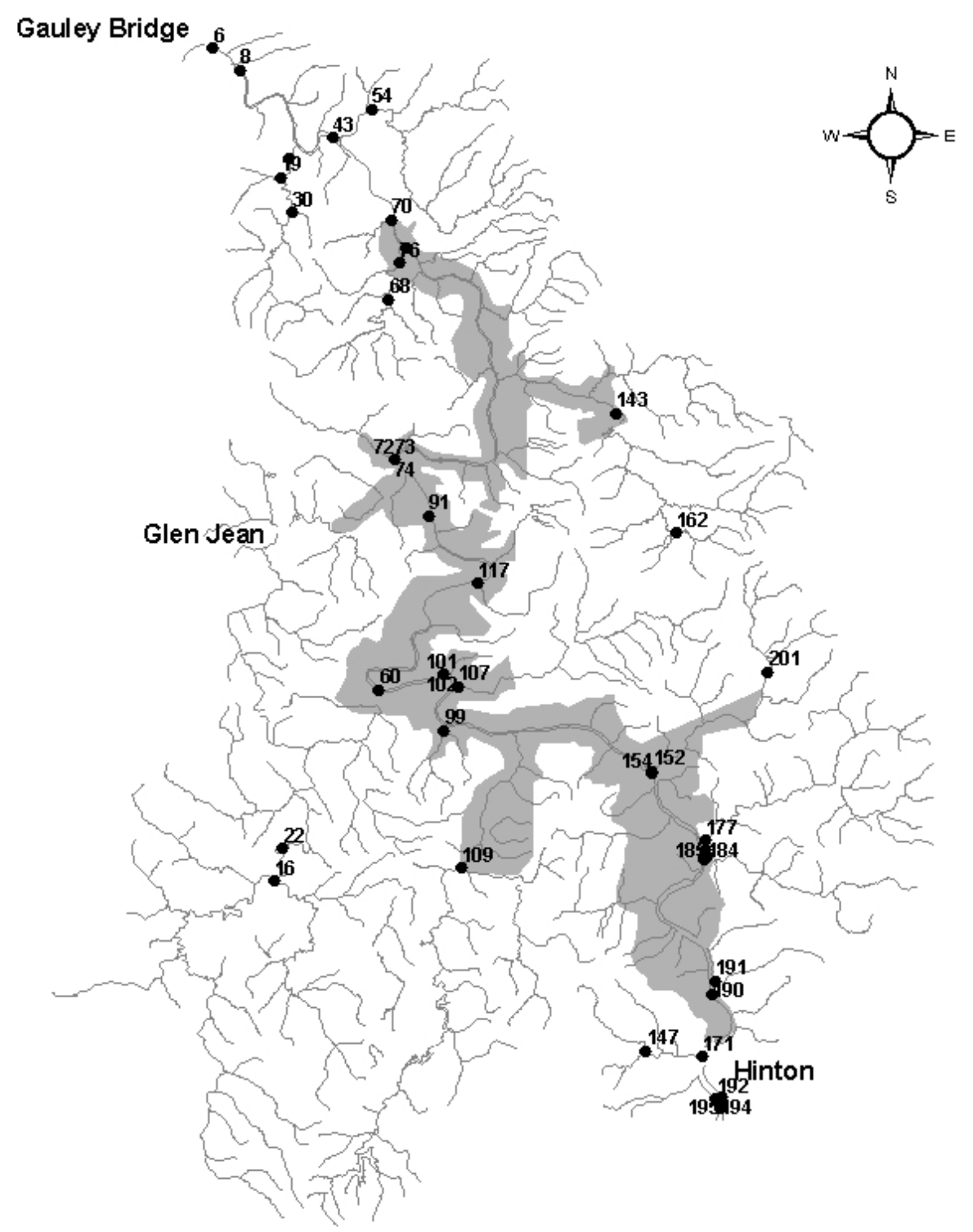

- Lepomis macrochirus

New River and tributaries

NRGNR boundary

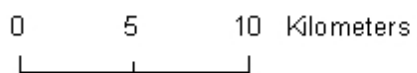

Figure 45. Collection sites for Lepomis macrochirus (bluegill) within and near the New River Gorge National River. 


\section{Lepomis megalotis (longear sunfish)}

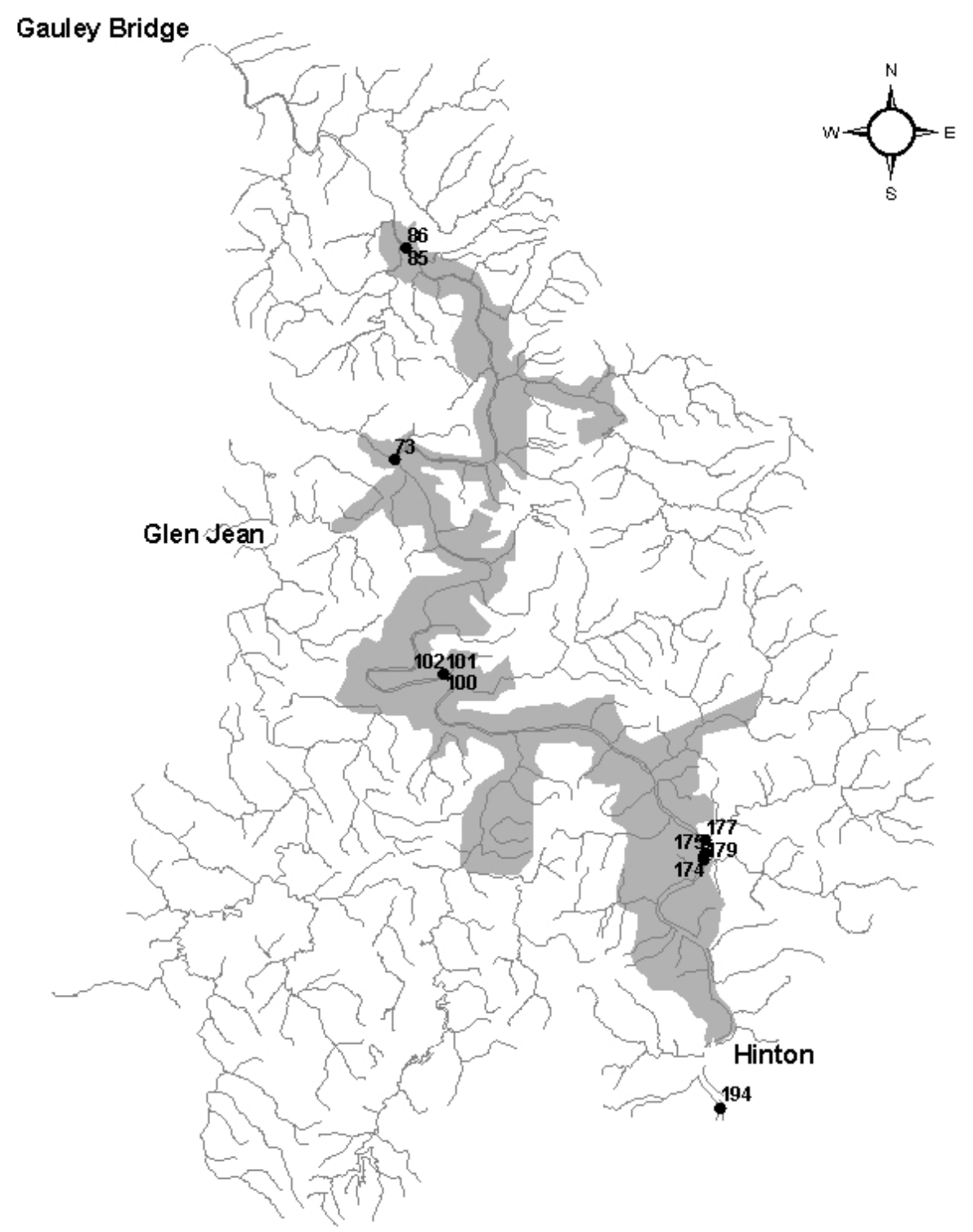

- Lepomis megalotis

New River and tributaries

NRGNR boundary

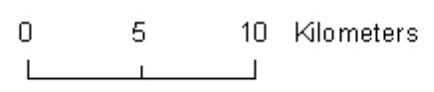

Figure 46. Collection sites for Lepomis megalotis (longear sunfish) within and near the New River Gorge National River. 


\section{Micropterus dolomieu (smallmouth bass)}

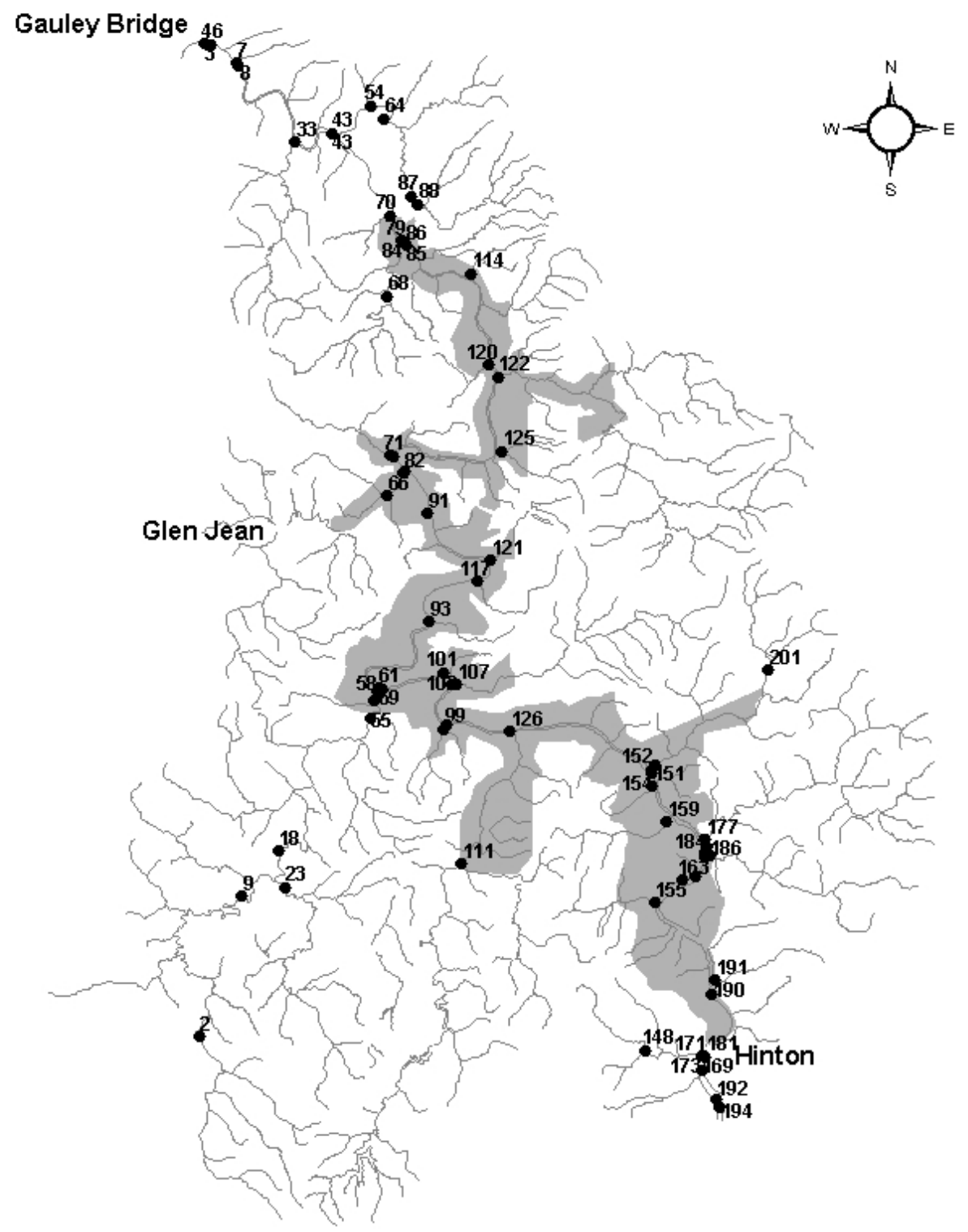

- Micropterus dolomieu

New River and tributaries

NRGNR boundary

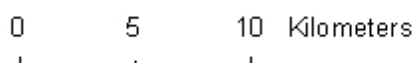

Figure 47. Collection sites for Micropterus dolomieu (smallmouth bass) within and near the New River Gorge National River. 


\section{Micropterus punctulatus (spotted bass)}

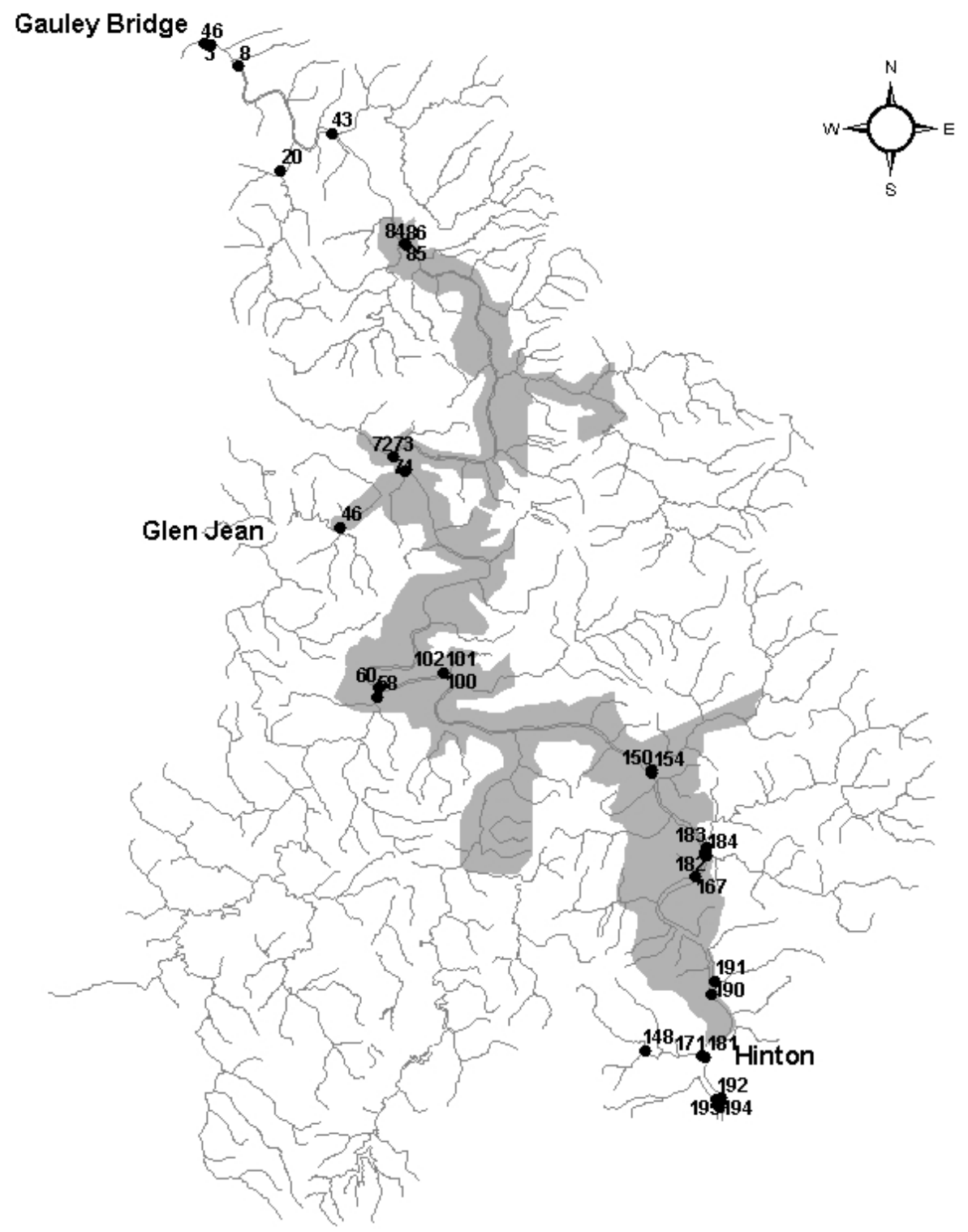

- Micropterus punctulatus

- New River and tributaries NRGNR boundary

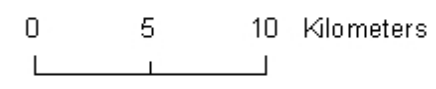

Figure 48. Collection sites for Micropterus punctulatus (spotted bass) within and near the New River Gorge National River. 


\section{Micropterus salmoides (largemouth bass)}

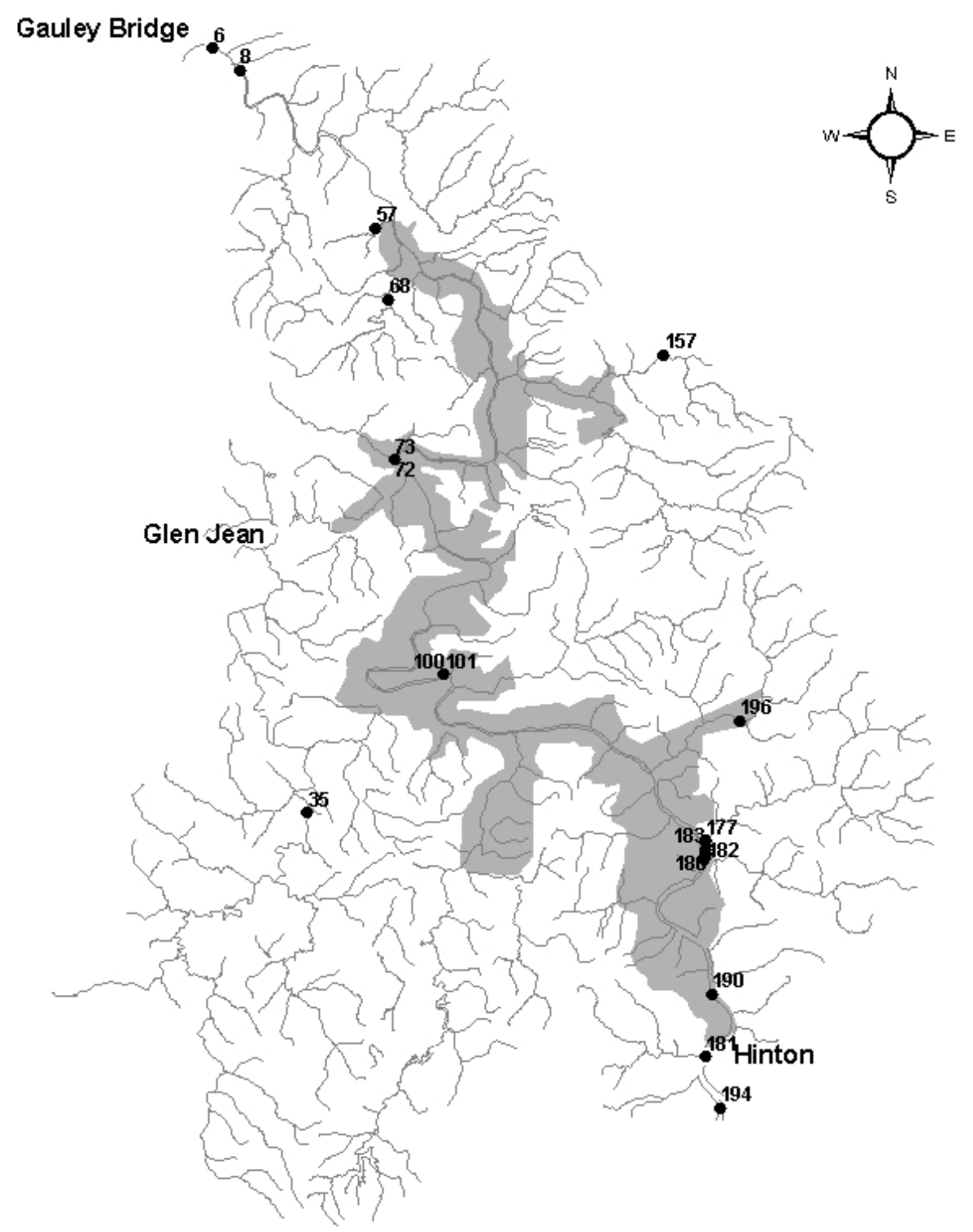

- Micropterus salmoides

New River and tributaries

NRGNR boundary

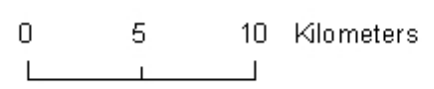

Figure 49. Collection sites for Micropterus salmoides (largemouth bass) within and near the New River Gorge National River. 


\section{Pomoxis annularis (white crappie)}

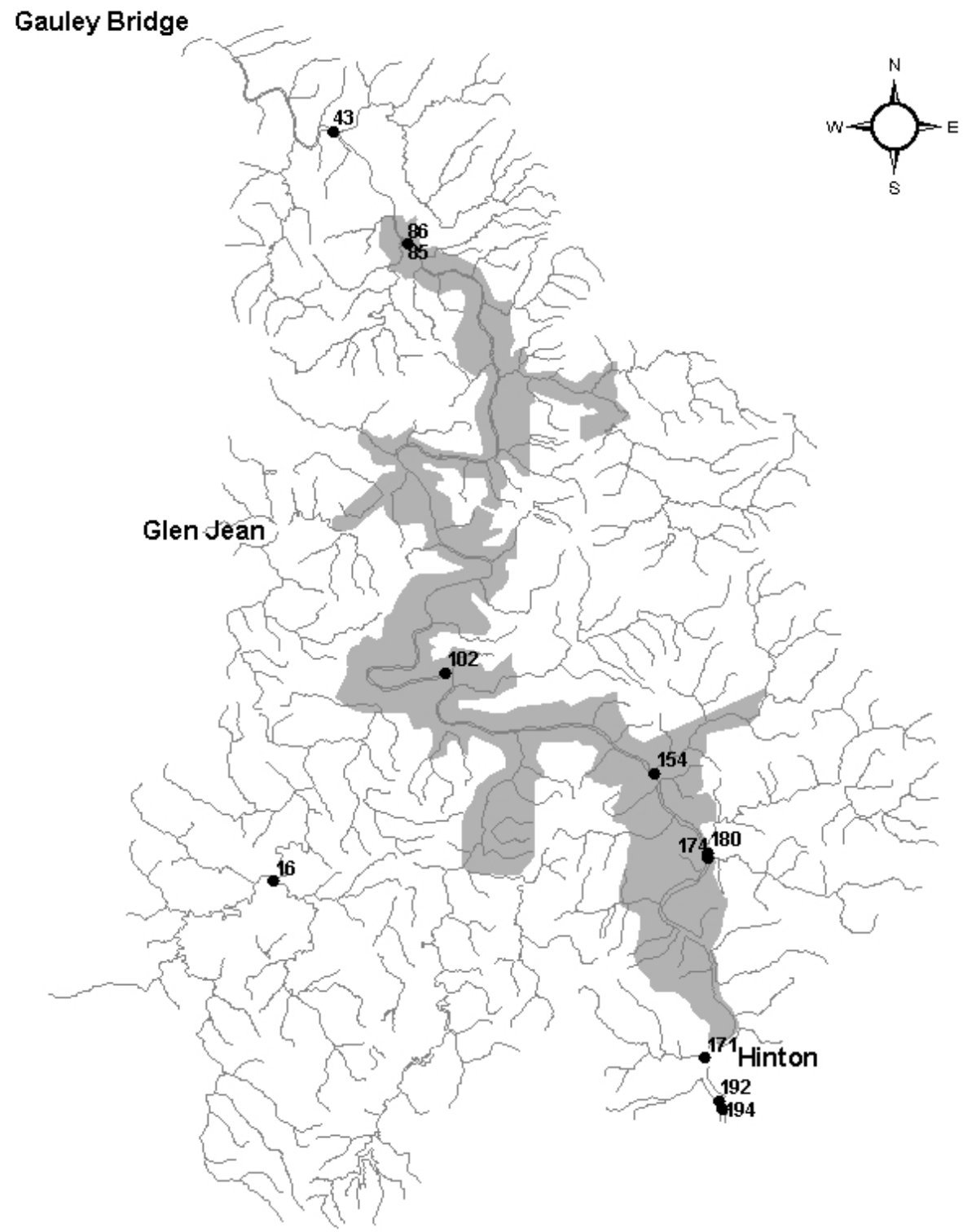

- Pomoxis annularis

New River and tributaries

NRGNR boundary

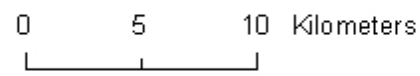

Figure 50. Collection sites for Pomoxis annularis (white crappie) within and near the New River Gorge National River. 


\section{Pomoxis nigromaculatus (black crappie)}

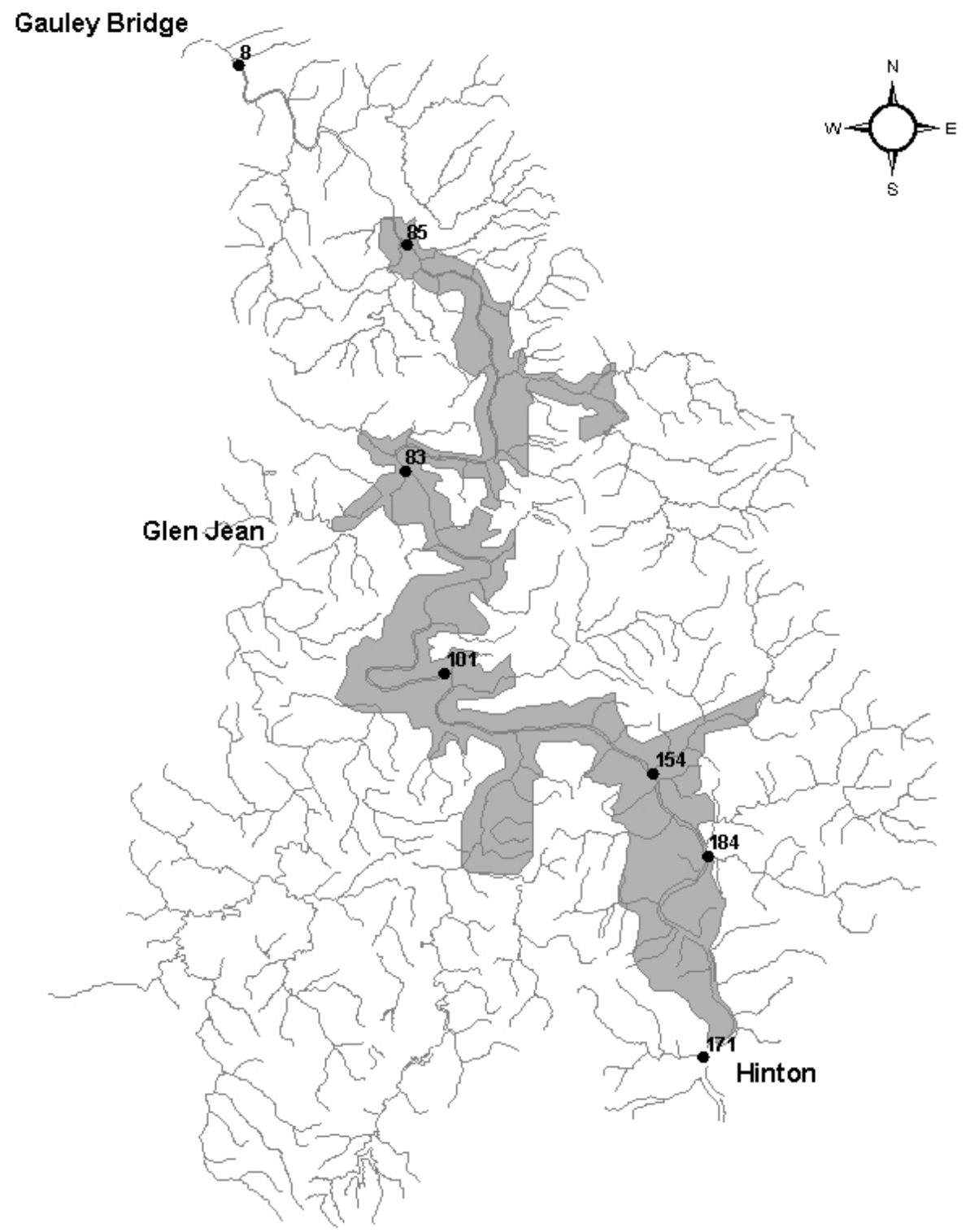

- Pomoxis nigromaculatus

New River and tributaries

NRGNR boundary

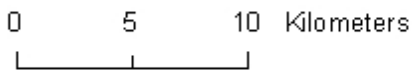

Figure 51. Collection sites for Pomoxis nigromaculatus (black crappie) within and near the New River Gorge National River. 


\section{Etheostoma blennioides (greenside darter)}

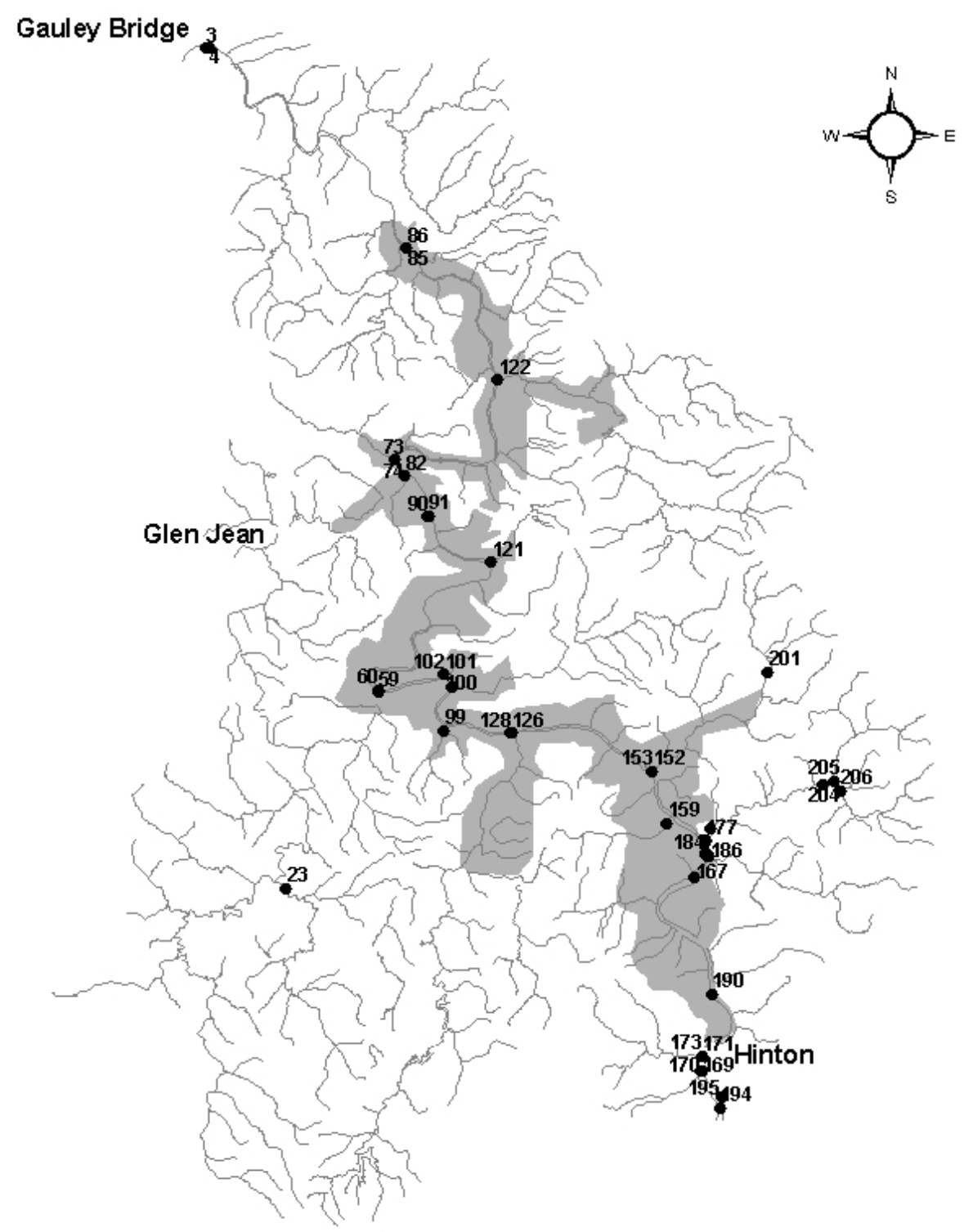

- Etheostoma blennioides

New River and tributaries

NRGNR boundary

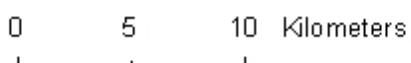

Figure 52. Collection sites for Etheostoma blennioides (greenside darter) within and near the New River Gorge National River. 


\section{Etheostoma caeruleum (rainbow darter)}

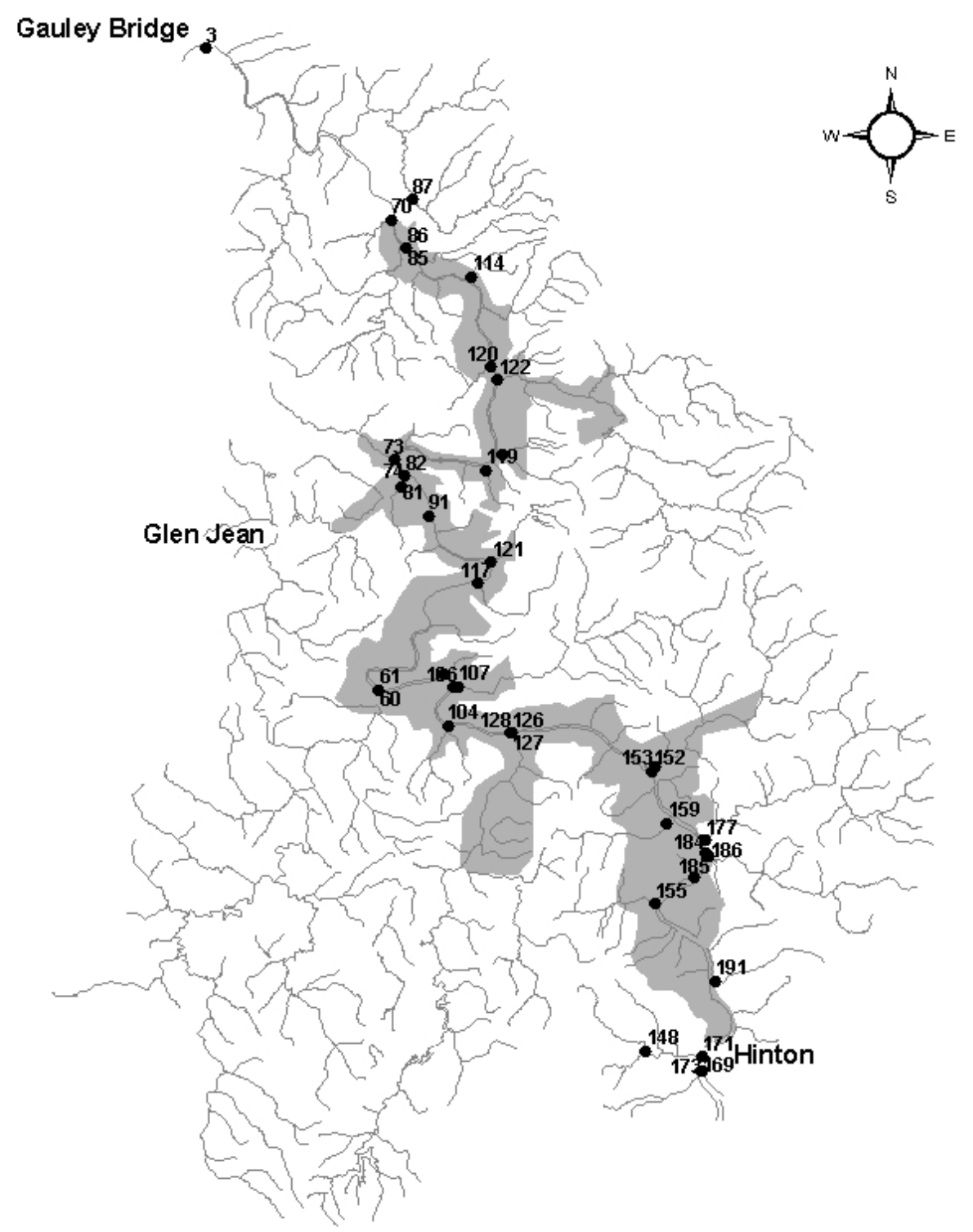

- Etheostoma caeruleum

New River and tributaries

NRGNR boundary

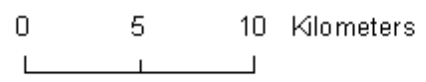

Figure 53. Collection sites for Etheostoma caeruleum (rainbow darter) within and near the New River Gorge National River. 


\section{Etheostoma flabellare (fantail darter)}

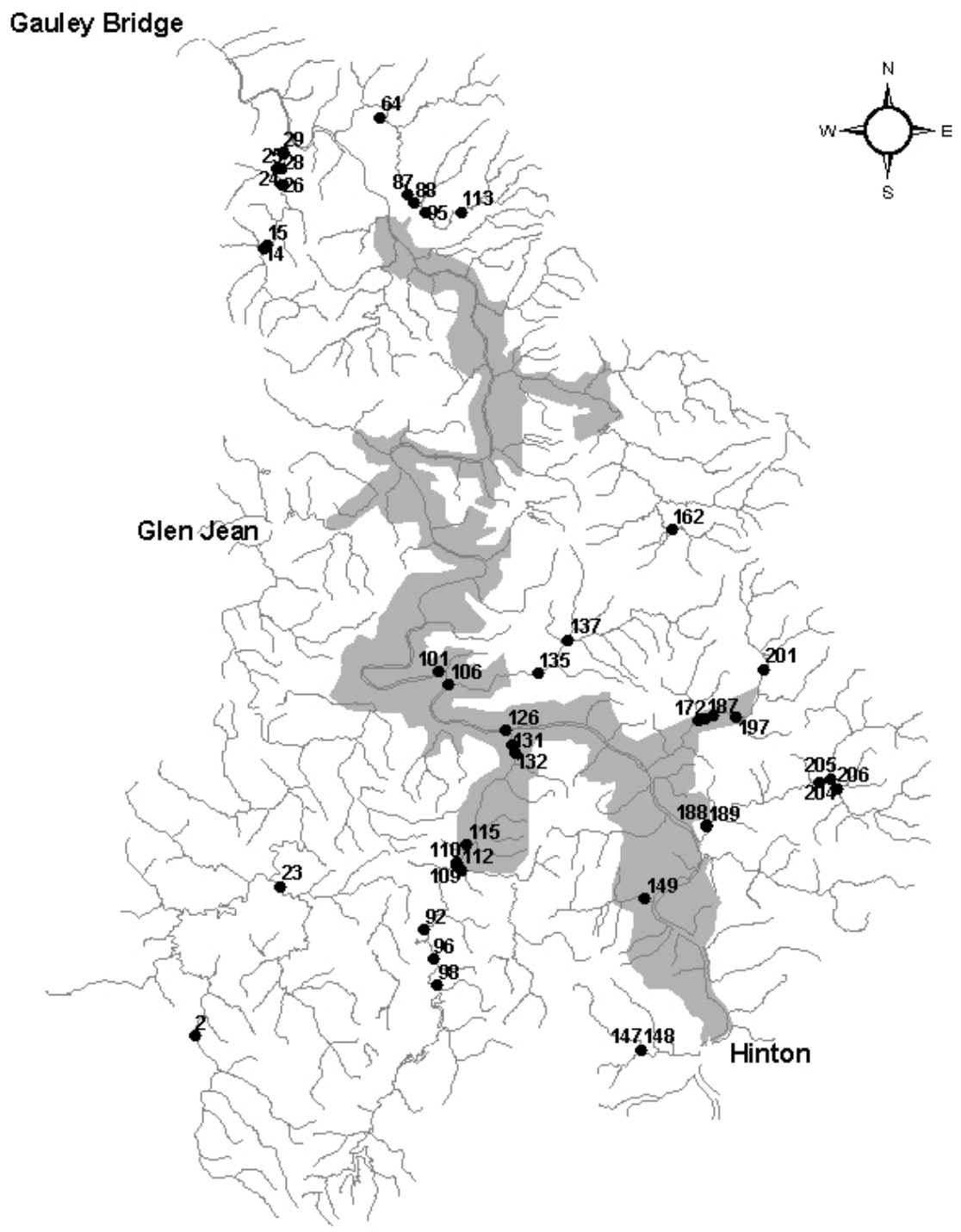

- Etheostoma flabellare

New River and tributaries

NRGNR boundary

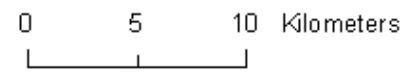

Figure 54. Collection sites for Etheostoma flabellare (fantail darter) within and near the New River Gorge National River. 


\section{Etheostoma nigrum (johnny darter)}

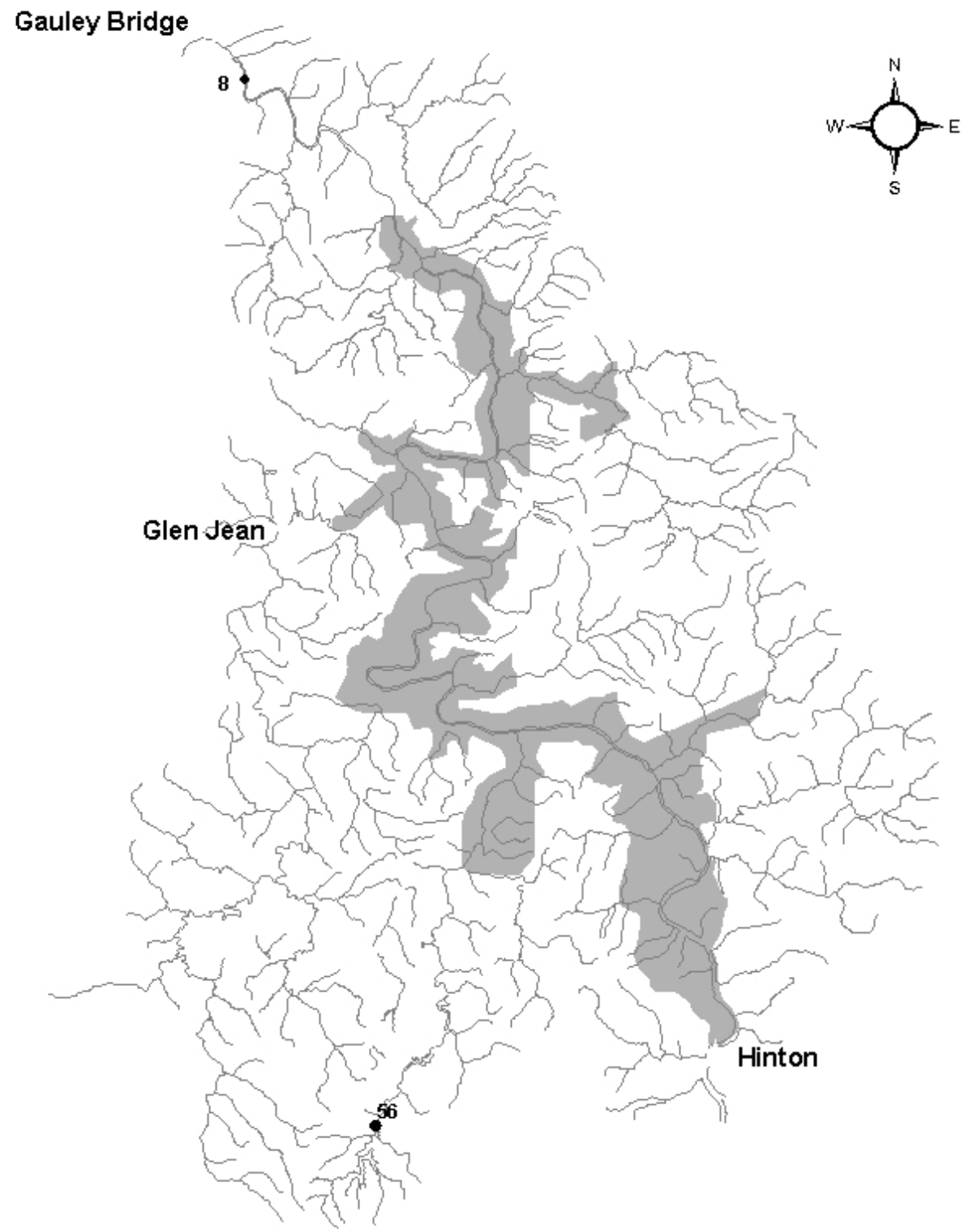

- Etheostoma nigrum

New River and tributaries

NRGNR boundary

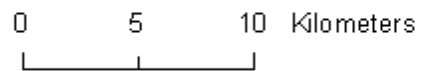

Figure 55. Collection sites for Etheostoma nigrum (johnny darter) within and near the New River Gorge National River. 


\section{Etheostoma variatum (variegate darter)}

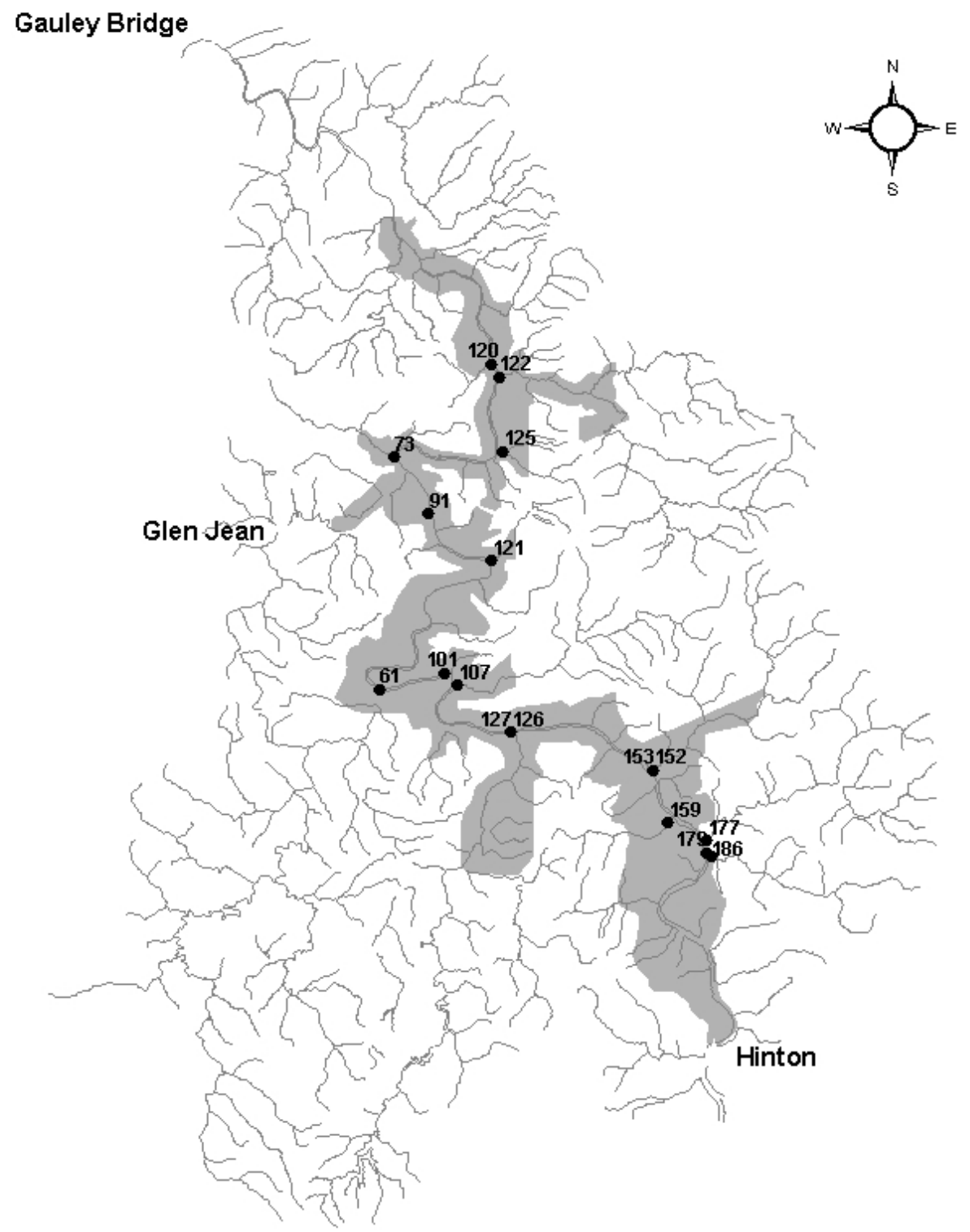

- Etheostoma variatum

New River and tributaries

NRGNR boundary

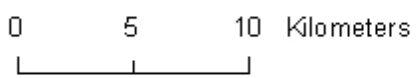

Figure 56. Collection sites for Etheostoma variatum (variegate darter) within and near the New River Gorge National River. 


\section{Percina caprodes (logperch)}

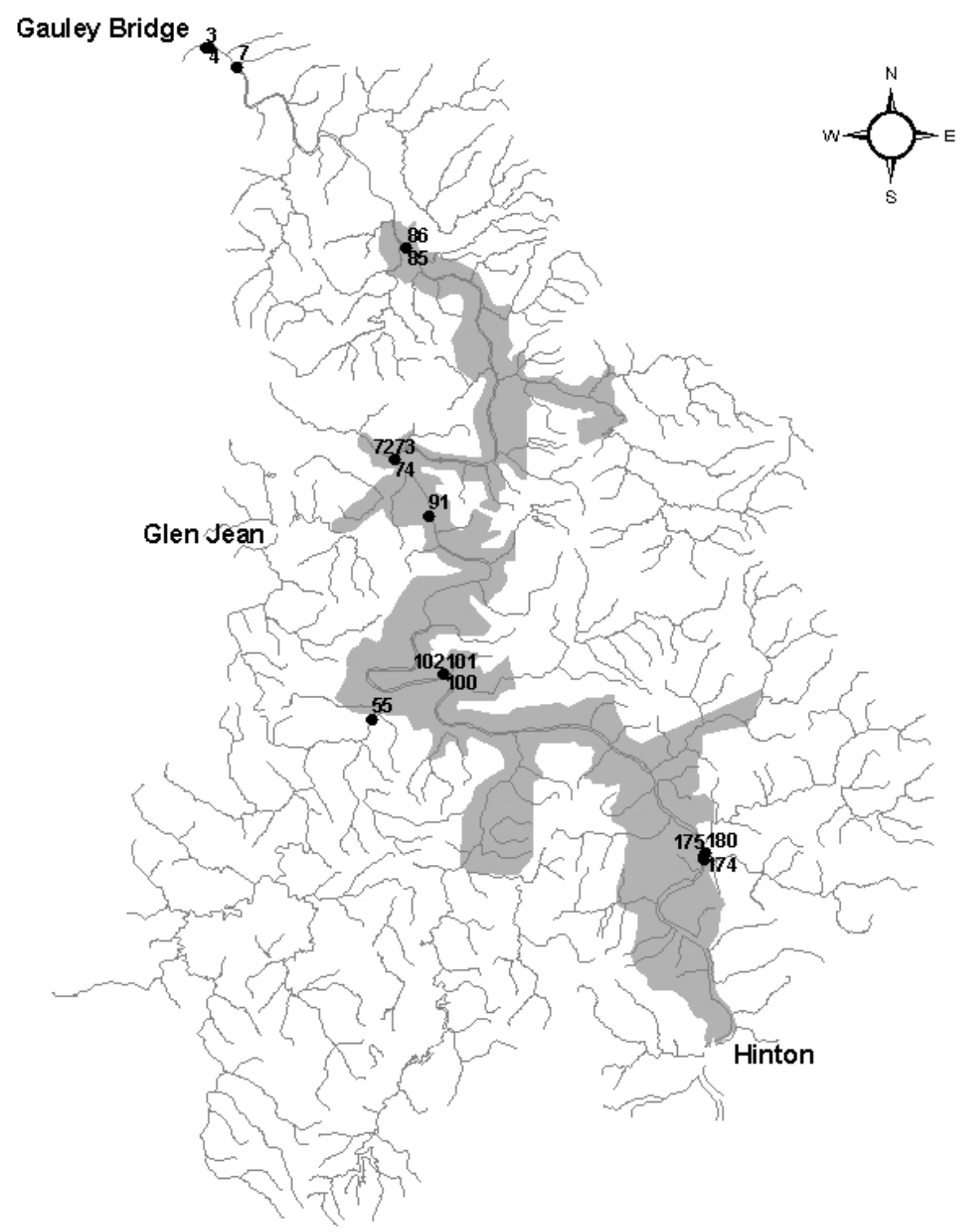

- Percina caprodes

New River and tributaries

NRGNR boundary

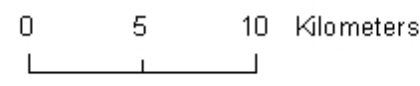

Figure 57. Collection sites for Percina caprodes (logperch) within and near the New River Gorge National River. 


\section{Percina maculata (blackside darter)}

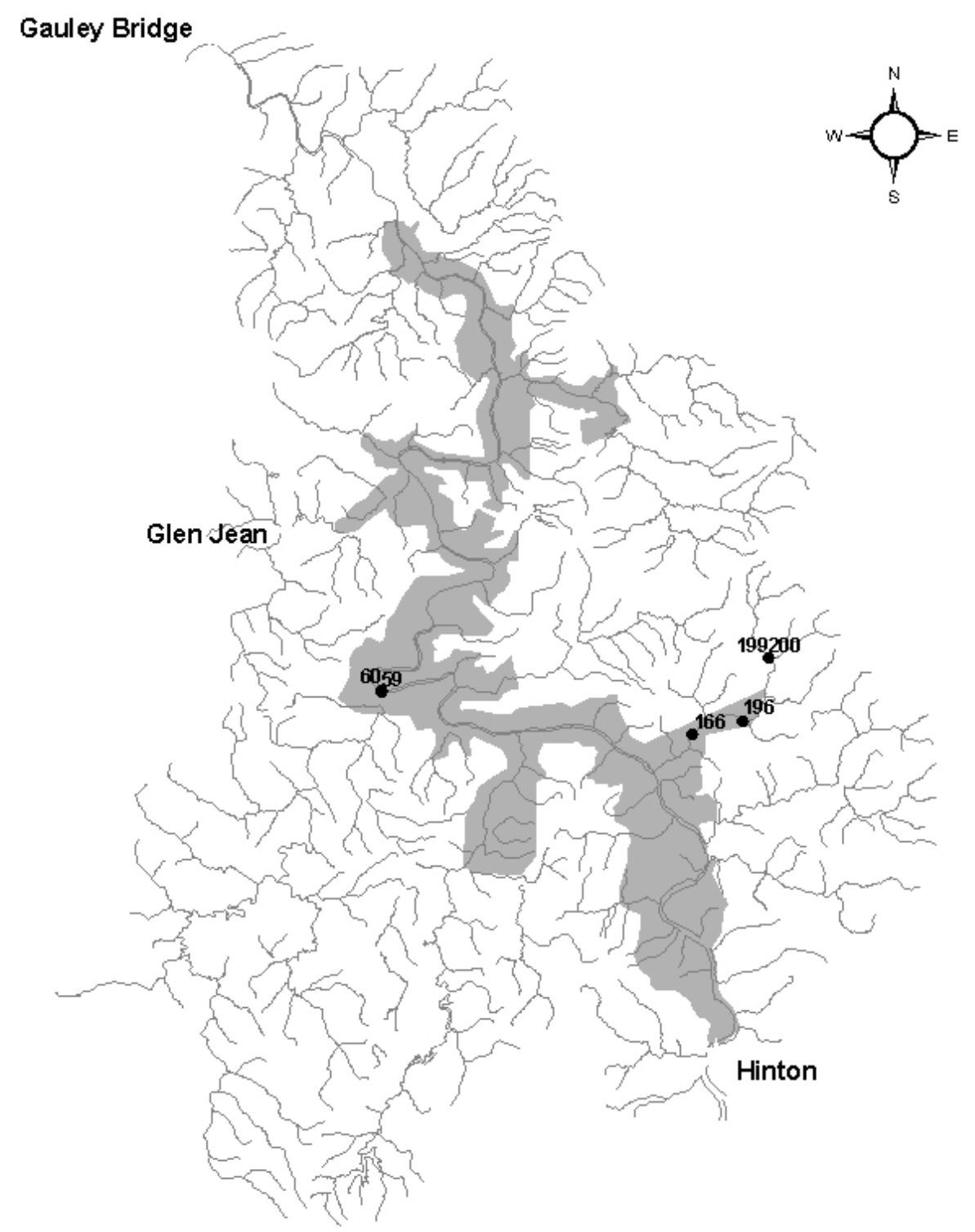

- Percina maculata

New River and tributaries

NRGNR boundary

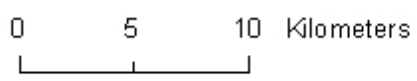

Figure 58. Collection sites for Percina maculata (blackside darter) within and near the New River Gorge National River. 


\section{Percina oxyrhynchus (sharpnose darter)}

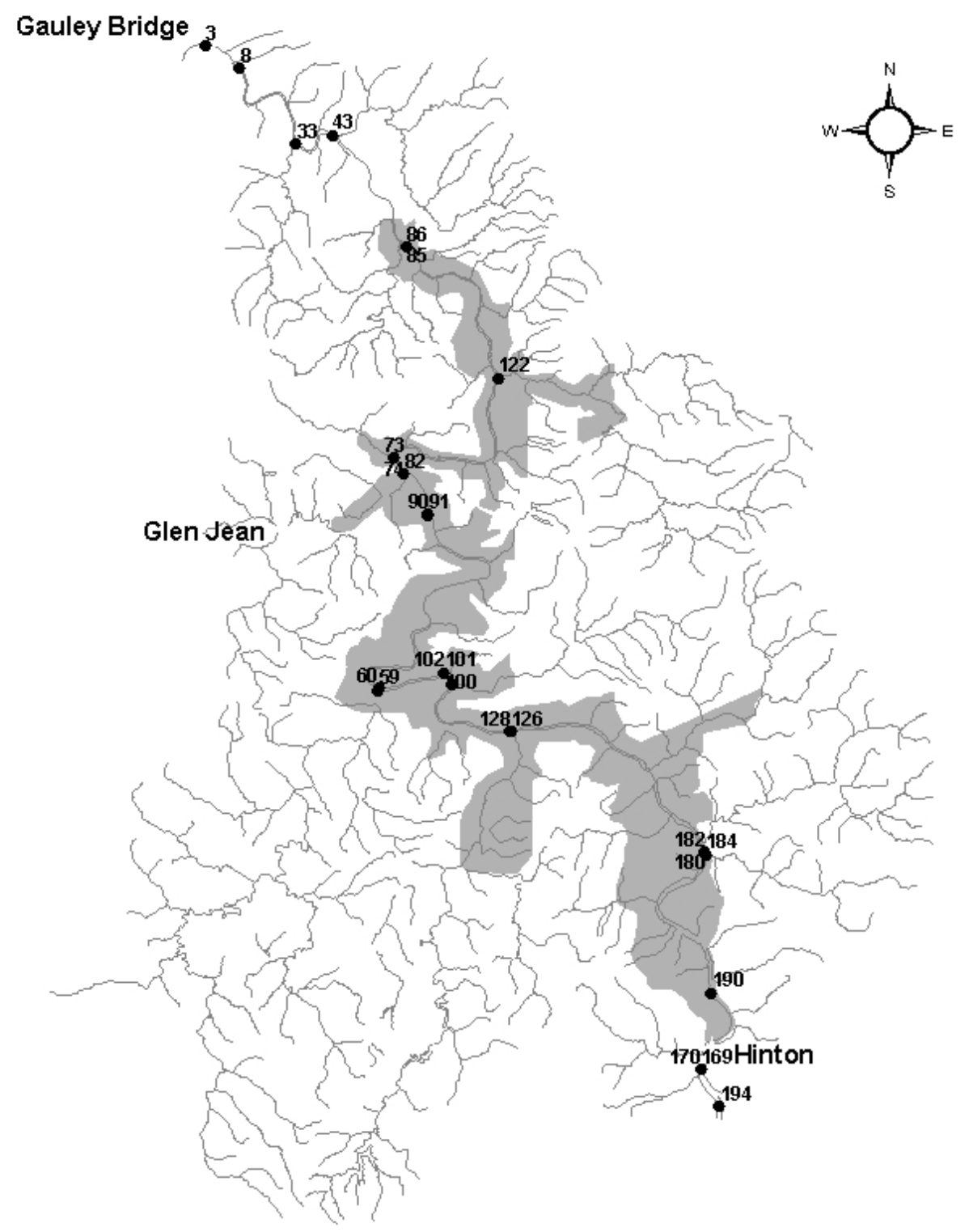

- Percina oxyrhynchus

New River and tributaries

NRGNR boundary

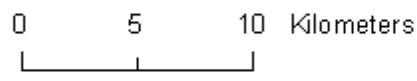

Figure 59. Collection sites for Percina oxyrhynchus (sharpnose darter) within and near the New River Gorge National River. 


\section{Percina roanoka (Roanoke darter)}

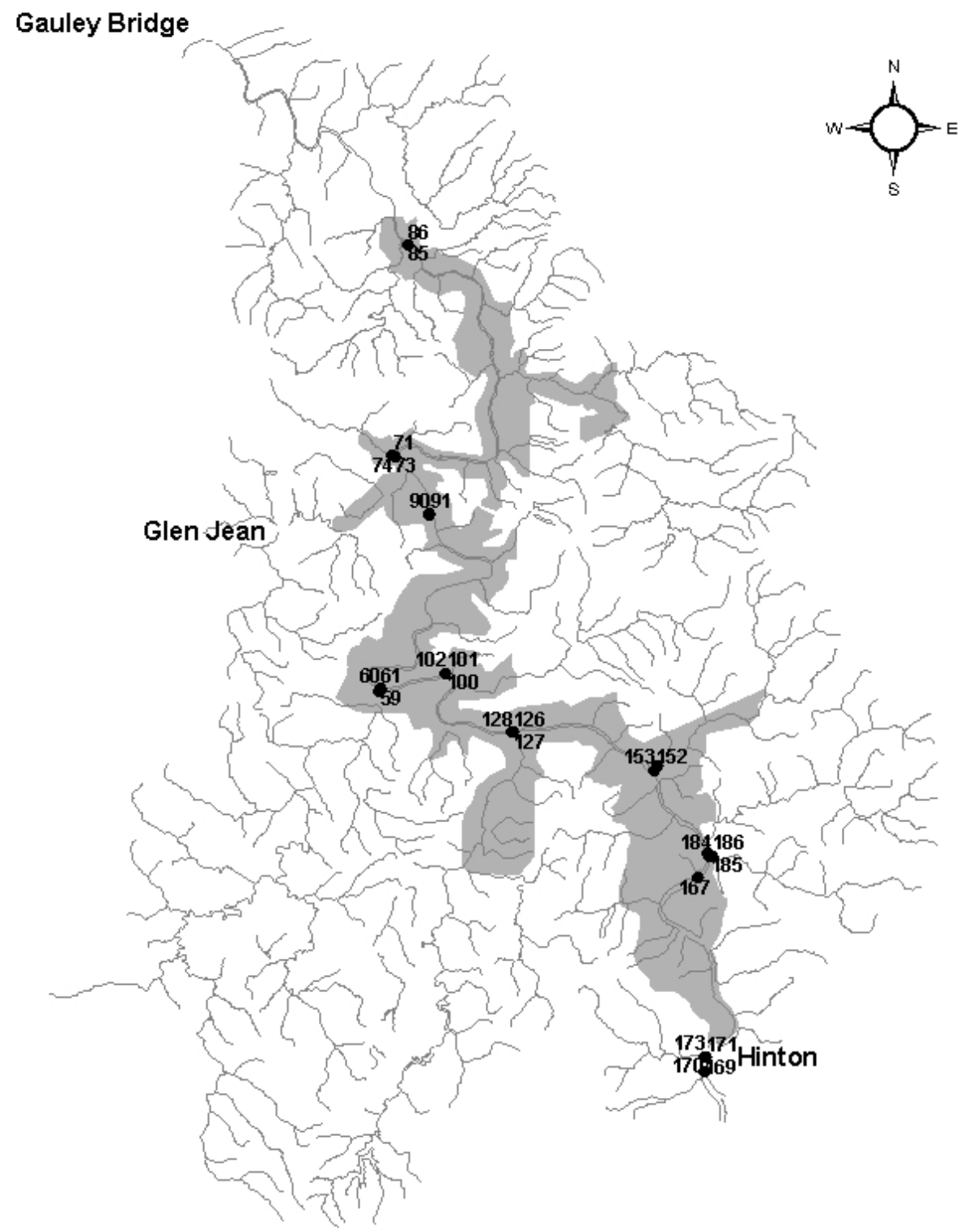

- Percina roanoka

New River and tributaries

NRGNR boundary

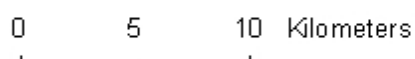

Figure 60. Collection sites for Percina roanoka (Roanoke darter) within and near the New River Gorge National River. 


\section{Perca flavescens (yellow perch)}

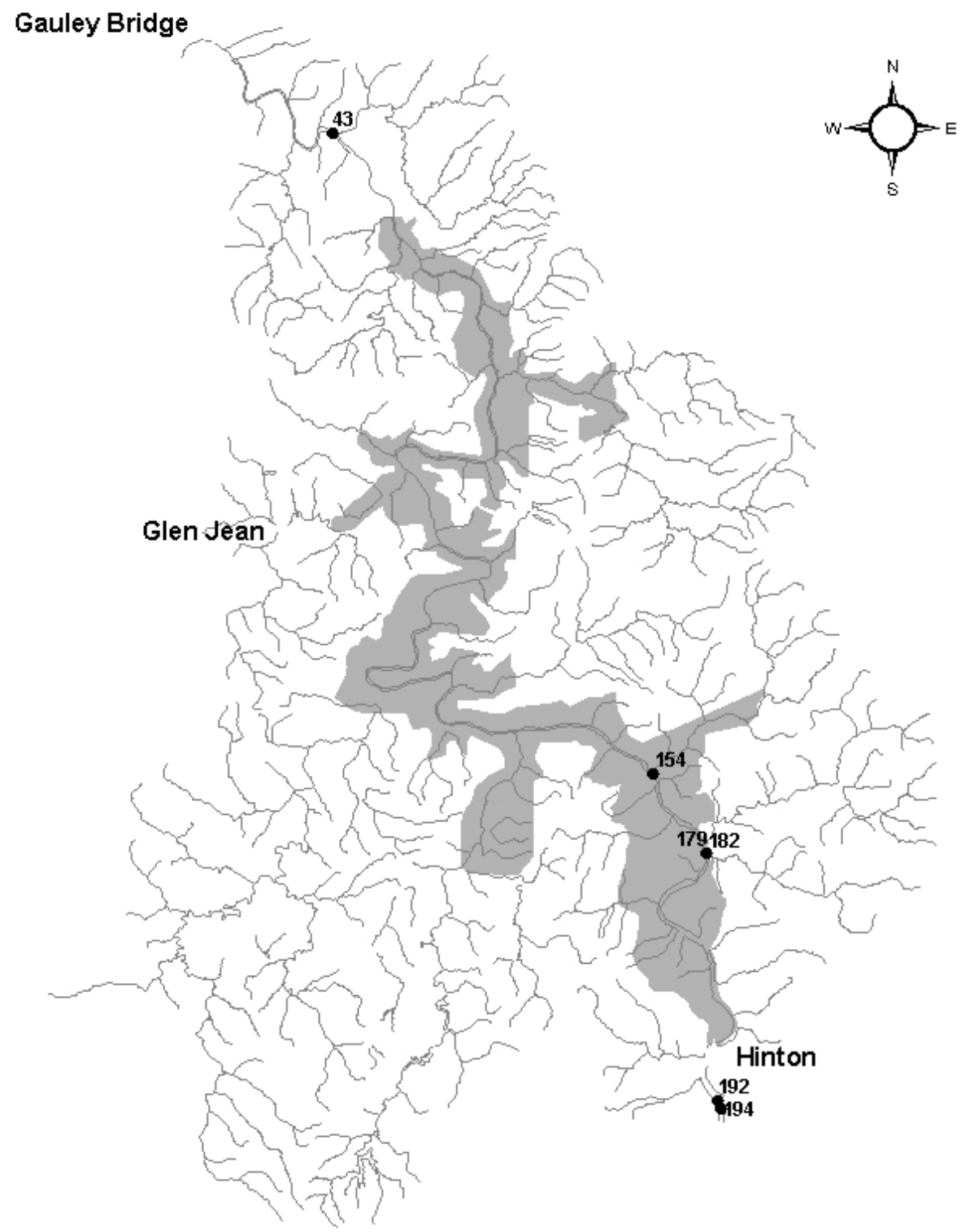

- Perca flavescens

New River and tributaries

NRGNR boundary

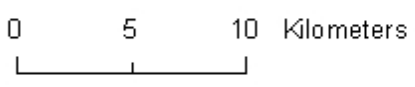

Figure 61. Collection sites for Perca flavescens (yellow perch) within and near the New River Gorge National River. 


\section{Sander vitreus (walleye)}

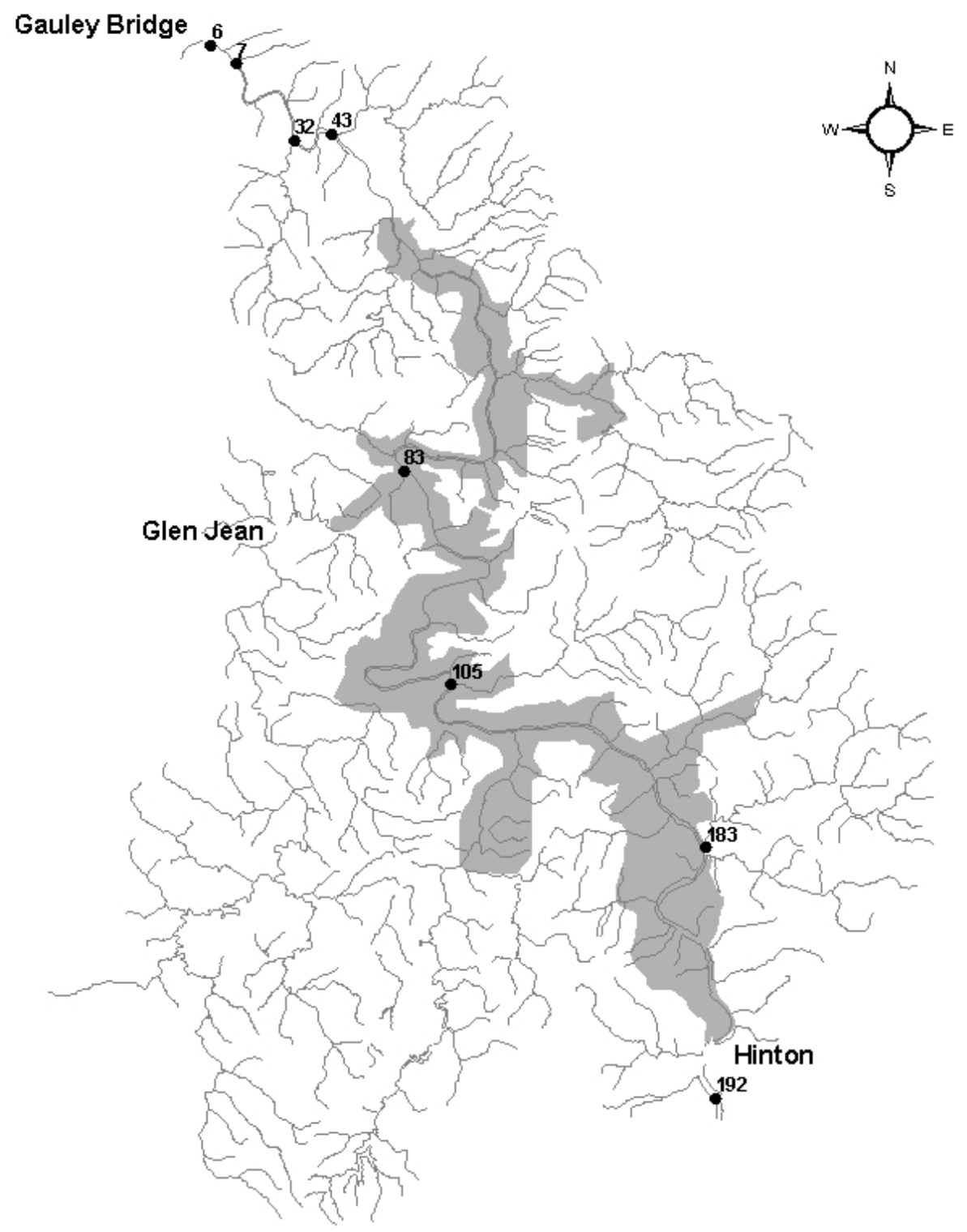

- Sander vitreus

New River and tributaries

NRGNR boundary

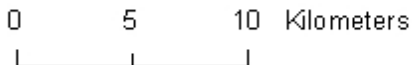

Figure 62. Collection sites for Sander vitreus (walleye) within and near the New River Gorge National River. 


\section{Scardinius erythrophthalmus (European rudd)}

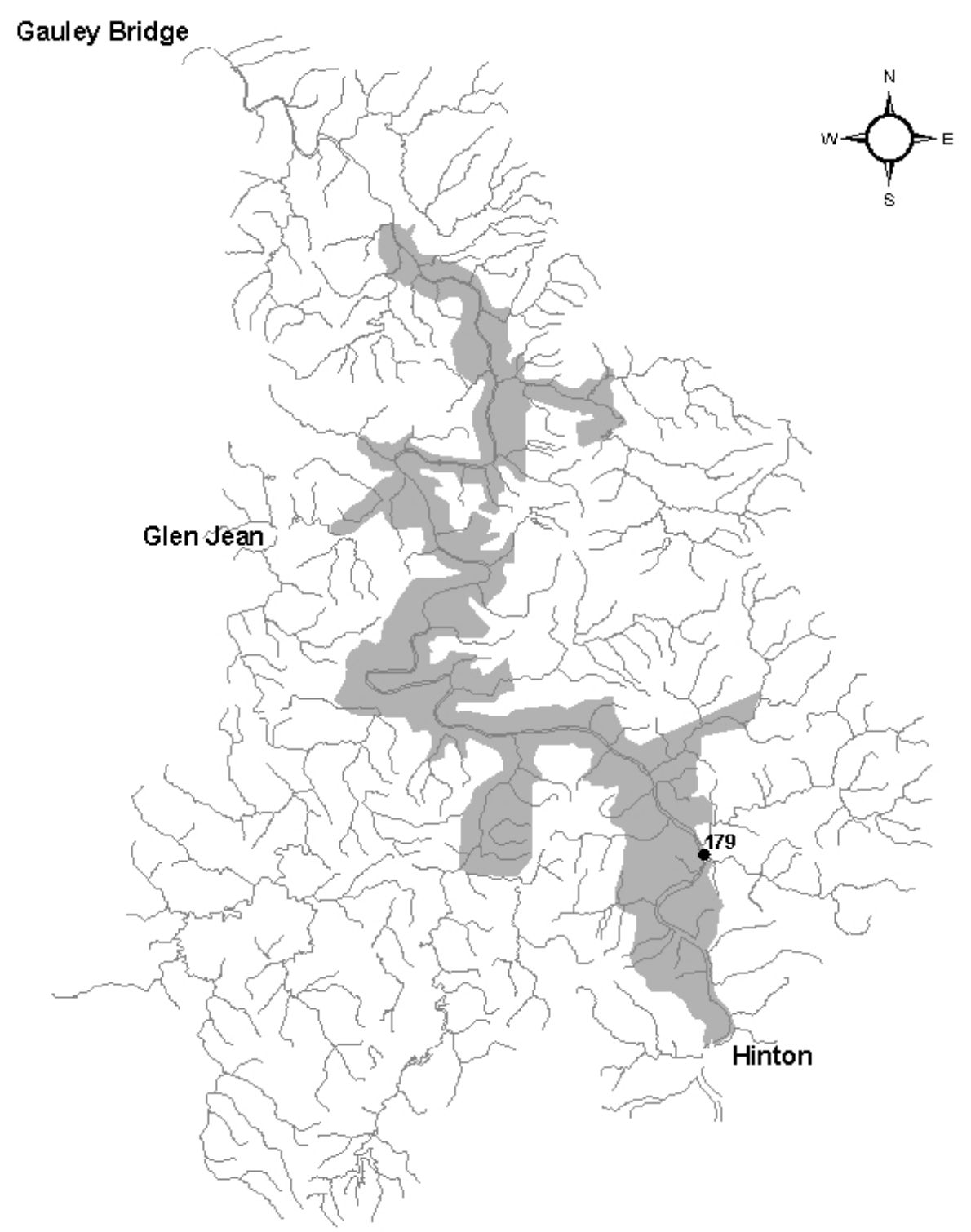

- Scardinius erythrophthalmus

New River and tributaries

NRGNR boundary

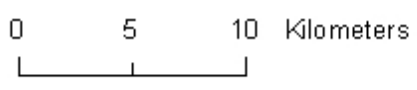

Figure 63. Collection sites for Scardinius erythrophthalmus (European rudd) within and near the New River Gorge National River. 


\title{
Chapter 3: Post-flood Recolonization of Native and Nonnative Fishes in Tributaries within New River Gorge National River, West Virginia
}

\begin{abstract}
Nonnative fishes represent an increasingly common biotic disturbance in lotic systems, and their interactions with native species are important to the conservation and management of fish communities. Biotic and abiotic disturbances synergistically influence fish communities in small unstable Appalachian streams, but interactions among multiple disturbances, such as nonnative species, floods, and droughts, are not well understood. The New River is a model system for the study of nonnative species; it contains the largest number and proportion of nonnative fishes in the eastern and central North American drainages (47 native and 45 nonnatives). In July 2001, flooding and debris flows within the lower section of the New River in New River Gorge National River (NRGNR) extirpated or reduced populations within small tributaries, and provided an opportunity to study recolonization and population recovery of native and nonnative fishes. Removal methods were used to estimate fish abundances at 12 tributary sites (nine flood impacted sites, and three reference sites) over a 20-month period (5 collection seasons). Although 29 species were observed (15 native and 14 nonnative), patterns of recolonization and population recovery were influenced primarily by four natives (stoneroller, blacknose dace, creek chub, and green sunfish) and four nonnatives (telescope shiner, whitetail shiner, smallmouth bass, and rainbow darter). Abundances of most species did not increase monotonically over the study period, but fluctuated among seasons. Abundances of nonnative fishes were generally less stable than those of natives across the study period. Seasonal variation in abundances among species was attributed to historic ecological factors, summer drought, immigration and emigration associated with seasonal habitat shifts, and juvenile recruitment.
\end{abstract}




\section{INTRODUCTION}

In lotic systems, synergistic effects of biotic and abiotic disturbances on fish abundances are not widely understood, but are important within a conservation framework of managing native fish communities (Cairns et al. 1971, Hughes et al. 1990, Reice et al. 1990, Detenbeck et al. 1992). The New River drainage provides a model system for addressing effects of biotic and abiotic disturbances on fish communities. In small tributaries of the New River system, introductions of nonnative fishes represent biotic disturbances, whereas floods and droughts are common abiotic disturbances.

The New River contains the largest number and proportion of nonnative fishes in the eastern and central North American drainages (47 native and 45 nonnative; Jenkins and Burkhead 1994, see Chapter 2). Eight of the 47 native species are endemic to the New River system, and thus possess conservational importance relative to potential negative impacts of nonnative fishes. Nonnative species may compete with natives in the New River system and the extent of possible negative impacts from competition is difficult to determine in observational field studies. Many factors dictate success of introduced fishes; system complexity, number of and abundance of native species, reproductive success of introduced species, size selection of predators on native and nonnative fishes, and competitive nature of native and introduced species (Ross 1991, Moyle and Light 1996). Nonnative species have many negative impacts on native species, such as habitat or trophic alterations, disease/parasite introductions, or hybridization (Ross 1991).

On the $8^{\text {th }}$ and $26^{\text {th }}$ of July 2001 , flood waters and debris flows reduced or extirpated populations of native and nonnative fishes in several small tributaries of the New River, WV, within New River Gorge National River (NRGNR). Rain fall ranged from 76-140 mm and 51- 
$102 \mathrm{~mm}$ within $3-6$ hour periods on July $8^{\text {th }}$ and $26^{\text {th }}$ respectively (NOAA 2003). Flood waters and debris flows restructured stream channels, scoured streambeds, removed riparian vegetation, and created large alluvial fans at tributary mouths. In contrast, West Virginia ranked $5^{\text {th }}$ among states in August 2002 drought conditions (NOAA 2003). Consequently, many tributaries within NRGNR were dewatered or reduced to scattered pools during summer 2002. These flood and drought events reduced or extirpated fish populations in lower reaches of small tributaries of NRGNR (personal observation).

Reice et al. (1990) emphasized a need to define the role of disturbance in frequently disturbed systems, and to observe recovery of fish populations following disturbances so that fisheries resources can be effectively managed (Cairns et al. 1971, Hughes et al. 1990, Detenbeck et al. 1992). Abundance data are useful when examining fish recovery following disturbances (Ensign et al. 1997). It is difficult to assess biotic disturbances caused by nonnative fishes because introduction events occur at different time periods. This study, however, is unique because extensive flood waters removed native and nonnative fishes from small tributaries within New River Gorge, and allowed direct assessment of recolonization and abundances of native and nonnative fishes during a 20-month (5 sampling occasions) post-flood time series. Study objectives were to estimate seasonal abundances of native and nonnative fishes in small tributaries of NRGNR over 20 months following the July 2001 floods, and to examine among-season stability in abundances of native and nonnative fishes over this same period. 


\section{METHODS}

\section{Study area}

The study was conducted within the boundaries of the NRGNR in southern West Virginia (Figure 1). The New River mainstem within NRGNR descends steeply through a deep gorge. River elevation ranges from about $427 \mathrm{~m}$ at the upstream end to about $244 \mathrm{~m}$ at the downstream end. The gorge rim rises typically $305 \mathrm{~m}$ above the New River with a maximum height of $488 \mathrm{~m}$ (Swift 2000). Smaller tributaries within NRGNR are extremely high gradient along the flanks of the gorge, and typically have three distinct sections; a mouth in the New River with a flood plain of low to moderate gradient, a steep descending section with cascades and water falls, and an upper plateau section with relatively low gradient. This study involved the lower, New River flood plain sections of 12 tributaries within NRGNR (Figure 2). Study streams were $1^{\text {st }}$ to $3^{\text {rd }}$ order with watersheds of $417-4,365$ hectares. In the downstream reaches of NRGNR, floods and debris flows in the nine flood-impacted streams, restructured channels, removed riparian vegetation, and created large alluvial fans at tributary mouths. These factors were relatively unchanged in three reference streams in the upstream reaches of NRGNR.

\section{Habitat data}

Stream width, substrate size, and stream gradient were measured to document similarities in the physical characteristics of study reaches. Wetted width, bankfull width and substrate size at eleven equi-distant transects along each stream reach were measured to obtain mean values for each category (USEPA 1997). Substrate size was estimated at four equally spaced points and the thalweg along each transect (USEPA 1997). Channel gradients of study sites were estimated with a hand level and stadia rod. 


\section{Fish Collections}

Fishes were collected from lower reaches of the study streams with backpack electrofishing unit during five seasons (fall 2001, spring, summer, and fall 2002, and spring 2003). At each site and season, fishes were collected with two or three passes through a stream reach, except for single passes in fall 2001. Only one pass was conducted during the first sampling season (approximately two months post-flood), because low abundances at this time prevented statistical estimation of population size. Stream reaches (with lowest point at the stream mouth) were approximately 40 times the mean wetted width with a minimum of 150 meters, except for streams with short flood plain sections. Due to narrow stream widths, backpack electrofishers efficiently captured fishes within the full width of the stream. For each pass, fishes were identified, measured (total length, TL) and counted. Fishes were released back into the sample reach following final pass of data collection.

\section{Statistical analysis}

For each stream site and season (except fall 2001), abundances of native and nonnative species were estimated with two or three-pass removal data (Program MARK, White 1999). Three detection probability models were fit to each three-pass data set, and included a behavioral response model, a constant model, and a model with a group effect (native vs. nonnative). Two models were fit to two-pass removal data; a constant detection probability model and a model with group effect (native vs. nonnative). The second-order adjustment of Akaike's information criterion (AICc) was used to weight models, where model-averaged abundance estimates and unconditional standard errors were calculated to account for model selection uncertainty (Burnham and Anderson 2003). To obtain estimates of abundance and variance by species origin and site category (i.e., natives at flood-impacted sites, nonnatives at flood-impacted sites, 
natives at reference sites, and nonnatives at reference sites), estimators were summed across sites (Mood et al. 1974; Thompson et al. 1998). A three-way analysis of variance (ANOVA; PROC GLM, SAS 1990) examined the following null hypotheses: 1) equal abundances between groups (native vs. nonnative), equal abundances among seasons, and equal abundances between sites (reference vs. flood-impacted). Significance level $(\alpha)$ was equal to 0.05 .

As a measure of temporal stability, coefficients of variation (CV) for total abundances of species across five seasons were estimated. For this approach, among-season variation in abundances was considered as a measure of stability, where a CV of zero represents no amongseason variation or the highest level of stability. The estimates of CV were aligned along an axis of stability for comparison among species with highest abundances, origin (native/nonnative), and site categories (flood-impacted/reference). The null hypotheses of no difference in $\mathrm{CV}$ values between groups of origin (native vs. nonnative) and between site categories (flood-impacted vs. reference) were tested with a two-way ANOVA (PROC GLM, SAS 1990; $\alpha=0.05)$.

\section{RESULTS}

Habitat

Mean wetted widths of study streams ranged from 2.0 to $5.6 \mathrm{~m}$ (Table 1). Stream substrates were generally gravel, cobble, and boulder and mean diameter of substrate size ranged from $54 \mathrm{~mm}$ to $360 \mathrm{~mm}$ (Table 1). Gradients for the three reference stream reaches $(\bar{x}=2.5 \%)$ in the upper section of NRGNR were lower than those of flood-impacted streams $(\bar{x}=7.4 \%)$. In general, streams with small watershed areas had highest gradients, and relatively short flood plain areas (which reduced the length of sample reach). 
Fish

We collected 29 species and 5,813 individuals from the 12 study streams during five sampling seasons (Table 2). Native species $(n=15)$ exceeded nonnatives $(n=14)$; however, the total number of nonnative individuals $(\mathrm{n}=3,133)$ was higher than that of natives $(\mathrm{n}=2,680)$. Approximately $93 \%$ of nonnative fishes consisted of five species; telescope shiner Notropis telescopus (20.5\%), whitetail shiner Cyprinella galactura (21\%), smallmouth bass Micropterus dolomieu (17\%), and rainbow darter Etheostoma caeruleum (31.5\%; Table 2). About 95\% of native fishes were comprised of four species; stoneroller Campostoma anomalum (57\%), blacknose dace Rhinichthys atratulus (23\%), creek chub Semotilus atromaculatus (9\%), and green sunfish Lepomis cyanellus (6\%; Table 2).

In all seasons, overall abundances of native and nonnative fishes in reference reaches exceeded those in flood-impacted reaches (Figure 3). Abundance estimates of native and nonnative fishes (when combined by species across sites) followed a similar pattern of amongseason variation (Figure 3), except for fall 2002 when non-native abundance $(n=1,623)$ exceeded that of native fishes $(\mathrm{n}=978)$. Low estimates of native and non-native abundances during summer 2002 coincided with drought conditions (Figure 3). A significant difference between estimated abundances of native and nonnative fishes was not detected $(\mathrm{F}=0.06, \mathrm{df}=1, \mathrm{p}=$ 0.82). However, estimated abundances from reference sites were significantly greater than estimated abundances of flood-impacted sites $(\mathrm{F}=109.83, \mathrm{df}=1, \mathrm{p}<0.001)$. Significant differences caused by seasonal effects on estimated abundances were also detected $(\mathrm{F}=31.02$, df $=4, \mathrm{p}=0.003)$.

The use of abundance estimates of native and non-native fishes (when combined by species across sites), however, obscured patterns of seasonal abundance among species. Based 
on total abundances for each species, variation in species abundances differed among seasons (Figure 4) and abundances of nonnative species were less stable than those of natives (Figure 5). Total abundances and CV values of the four most common native species were more stable than those of the four most common nonnatives across the 20-month study period (Figures 4 and 5). Stability of native fishes, as measured by CV values, significantly exceeded nonnative stability $(\mathrm{F}=5.82 ; \mathrm{df}=1, \mathrm{p}=0.033)$. Stonerollers, blacknose dace, and creek chub maintained higher stabilities of among-season abundance, in part, due to the presence of juveniles and adults in all seasons (Appendix 1), and the ability to remain within study sites during summer drought conditions. Green sunfish maintained stable but low abundances over the study period, but a high number of juvenile immigrants during spring 2002 increased among-season instability estimates of reference sites.

Among-season variation in numbers of nonnative fishes exceeded that of native species (Figure 3); a pattern largely driven by high seasonal variation in abundances of adult whitetail and telescope shiners (Figures 4 and 5). The nonnative Cyprinella galactura was rarely collected during most seasons, except for fall 2002 when it was the most abundant ( $\mathrm{n}=652)$ species (Figure 4). Notropis telescopus and M. dolomieu also reached highest abundances during fall seasons, and were relatively uncommon in tributaries during spring and summer seasons (Figure 4). Etheostoma caeruleum, the most abundant non-native fish (Table 2), was represented almost exclusively by adults (Appendix 1) and numbered highest during spring and lowest in summer and fall in both reference and flood-impacted sites (Figure 4).

\section{DISCUSSION}

The 20-month post-flood study period provided insights on recolonization and population recovery of native and nonnative fishes. Although 29 species were observed, patterns of 
recolonization and population recovery were influenced primarily by four natives (stoneroller, blacknose dace, creek chub, and green sunfish) and four nonnatives (telescope shiner, whitetail shiner, smallmouth bass, and rainbow darter). Most populations extirpated or reduced by July 2001 floods did not increase monotonically over the 20-month study period, but rather species abundances fluctuated among seasons. Abundances of nonnative fishes were generally less stable than those of natives across the 20-month time series. Seasonal variation in abundances among species was attributed to historic ecology, summer drought, immigration and emigration associated with seasonal habitat shifts, and juvenile recruitment.

High among-season variation in abundances of nonnative fishes may reflect historic ecological factors (John 1964, Ross et al. 1985, Matthews 1986, 1998). One of the dominant native species (green sunfish) and all of the dominant nonnatives (telescope shiner, whitetail shiner, smallmouth bass, and rainbow darter) are typical inhabitants of medium to large rivers within their native ranges; consequently, seasonal shifts to and from mainstem and tributary habitats may account for a large portion of seasonal variation in abundances. In contrast, three of the dominant natives (stoneroller, blacknose dace, and creek chub) are common inhabitants of small unstable Appalachian streams. Species in unstable streams are normally small, agile, early maturing, and rapid recolonizers with a wide range of physiological tolerances (Fausch and Bramblett 1991). Because floods have impacted fish communities throughout history, species in flood-prone areas lacking these characters have been selected against (Gorman and Karr 1978, Ross and Baker 1983, Moyle and Vondracek 1985). Biotic effects of floods should be minimal if fishes are adapted to frequent high discharges (Harrell 1978, Matthews 1998). Meffe and Minckley (1987) suggested stream fish assemblages are persistent in species presence, but vary in abundances following major disturbances. 
Many stream reaches were reduced to small isolated pools within NRGNR during summer 2002 as West Virginia ranked fifth in the nation for August drought conditions (NOAA 2003). Overall, fish abundances decreased during summer 2002. Increased temperatures, decreased dissolved oxygen, and limited mobility are most likely responsible for the decline (Tramer 1977, Matthews 1998). Tolerance of high temperatures and low dissolved oxygen differ among species, and some fishes are able to survive in refuge pools during droughts (Capone and Kushlan 1991). Creek chub and green sunfish are common inhabitants of pools and their relatively stable seasonal abundances may reflect the importance of pool habitats in frequently disturbed areas such as the NRGNR. Tramer (1977) observed highest mortalities in fishes with subterminal mouths and no air bladders (i.e. darters) in refuge pools during summer months. During summer 2002, lower abundances of rainbow darter may have resulted from emigration during late spring, or mortality owing to summer drought conditions. In reference sites, blacknose dace and creek chub increased in abundance during summer 2002 due to higher numbers of juveniles, while stoneroller abundance decreased due to loss of adults. Higher overall abundances in reference sites during summer is partly explained by higher numbers of juveniles, but may also be related to cooler water temperatures of some tributaries that have more canopy cover than the New River mainstem. At flood-impacted sites, canopy cover decreased due to girdling or removal of trees by July 2001 floods. Therefore, lower abundances during summer 2002 may be indirectly related to elevated water temperatures, caused by flood-induced removal of riparian cover.

Immigration associated with habitat shifts and juvenile recruitment influenced seasonal fluctuations in abundances and differences among species in seasonal abundance. The native fishes with highest abundances or greater stabilities (stoneroller, blacknose dace, and creek chub) 
are common to small tributaries, whereas telescope and whitetail shiners prefer medium to large rivers in their native range. Telescope and whitetail shiners may use smaller tributaries as refuge habitat during fall. Additionally, juvenile smallmouth bass may have used smaller tributaries during fall to avoid predation. High abundances and stability of the three common native species (stoneroller, blacknose dace, and creek chub) were enhanced by the presence of juveniles and adults. Juveniles of native species could have resulted from reproduction within study sites or may represent immigrants from the New River mainstem. Based on expected spawning times (Jenkins and Burkhead 1994), however, juveniles of stoneroller, blacknose dace, and creek chub present in fall 2001 and spring 2002 were immigrants. High telescope and whitetail shiner abundances during fall in reference and flood-impacted reaches were primarily comprised of adults, except for the presence of juvenile whitetail shiners in reference sites during fall 2002. Because no whitetail shiners and few telescope shiners were collected during spring and summer in reference and flood-impacted sites, it is likely that adult and juvenile telescope and whitetail shiners represent immigrants from the mainstem New River.

\section{CONCLUSION}

Post-disturbance data on species abundances provide useful insight towards understanding fish recovery following disturbances. In this study, among-season variation in native and nonnative abundances during a 20 -month post-flood period was associated with historic ecological factors, summer drought, immigration and emigration associated with seasonal habitat shifts, and juvenile recruitment. Seasonal abundance data supported stability of native fishes following sequences of major disturbances within small tributaries of the New River. In contrast, nonnative fish abundances were less stable among seasons in small tributaries. However, this may not imply that nonnative fish were less resilient than native 
species in the NRGNR. There was no statistical difference between native and nonnative fish abundances, though abundances at references sites exceeded those of flood-impacted sites. Also, abundances of nonnatives during fall exceeded those of other seasons; a pattern that likely reflects seasonal use of small tributaries by riverine species. 


\section{LITERATURE CITED}

Cairns, J., J. S. Crossman, K. L. Dickson, and E. E. Herricks. 1971. The recovery of damaged streams. Association of Southeastern Biologist Bulletin 18:79-106.

Capone, T. A. and J. A. Kushlan. 1991. Fish community structure in dry-season stream pools. Ecology 72:983-992.

Carling, P. 1988. The concept of dominant discharge applied to two gravelbed streams in relation to channel stability thresholds. Earth Surface Processes and Landforms 13:355367.

Detenback, N. E., P. W. Devore, G. J. Niemi, and A. Lima. 1992. Recovery of temperatestream fish communities from disturbance: A review of case studies and synthesis of theory. Environmental Management 16:33-53.

Dolloff, C. A., P. A. Flebbe, and M. C. Owen. 1994. Fish habitat and fish populations in a southern Appalachian watershed before and after Hurricane Hugo. Transactions of the American Fisheries Society 123:668-678.

Ensign, W. E., K. N. Leftwich, P. L. Angermeier, and C. A. Dolloff. 1997. Factors influencing stream fish recovery following a large-scale disturbance. Transactions of the American Fisheries Society 126: 895-907.

Fausch, K. D. and R. G. Bramblett. 1991. Disturbance and fish communities in intermittent tributaries of a western Great Plains river. Copeia 1991:659-674.

Fisher, S. G., L. J. Gray, N. B. Grimm, and D. E. Busch. 1992. Temporal succession in a desert stream ecosystem following flash flooding. Ecological Monographs 52:93-110.

Gorman O. T. and J. R. Karr. 1978. Habitat structure and stream fish communities. Ecology 59:507-515.

Grossman, G. D., J. F. Dowd, and M. Crawford. 1990. Assemblage stability in stream fishes: A review. Environmental Management 14:661-671.

Hack, J. T. and J. C. Goodlet. 1960. Geomorphology of forest ecology of a mountain region in the central Appalachians. U.S. Geological Survey Professional Paper 347.

Hanson D. L. and T. F. Waters. 1974. Recovery of standing crop and production rate of a brook trout population in a flood-damaged stream. Transactions of the American Fisheries Society 103:431-439. 
Harrel, H.L. 1978. Response of the Devil's River (Texas) fish community to flooding. Copeia 1978:60-68.

Hoopes, R. L. 1975. Flooding as the result of Hurricane Agnes, and its effect on native brook trout population in an infertile headwater stream in central Pennsylvania. Transactions of the American Fisheries Society 1:96-99.

Hughes, R. M., T. R. Whittier, C. M. Rohm, and D. P. Larsen. 1990. A regional framework for establishing recovery criteria. Environmental Management 14:673-683.

Jenkins, R. E. and N. M. Burkhead. 1993. Freshwater Fishes of Virginia. American Fisheries Society. Bethesda, Maryland.

John, K. R. 1964. Survival of fish in intermittent streams of the Chiricahua Mountains. Arizona Ecology 45:112-119.

Matthews, W. J. 1986. Fish faunal structure in an Ozark stream: stability, persistence, and a catastrophic flood. Copeia 1986:388-397.

Matthews, W. J. 1998. Patterns in Freshwater Fish Ecology. Kluwer Academic Publishers. Norwell, Massachusetts.

Meffe, G.K. and W. L. Minckley. 1987. Persistence and stability of fish and invertebrate assemblages in a repeatedly disturbed Sonoran Desert stream. American Midland Naturalist 117:177-191.

Mood, A.M., Graybill, F.A., and Boes, D.C. 1974. Introduction to the theory of statistics, third edition. McGraw-Hill, New York.

Moyle, P. B. and T. Light. 1996. Fish invasions in California: Do abiotic factors determine success? Ecology 77:1666-1670.

Moyle, P. B. and B. Vondracek. 1985. Persistence and structure of the fish assemblage in a small California stream. Ecology 66:1-13.

National Oceanic Atmospheric Administration (NOAA). Extreme Weather and Climate Events. URL http://www.ncdc.noaa.gov/oa/climate/severeweather/extremes.html

Pearsons, T. N., H. W, Li, and G. A. Lamberti. 1992. Influence of habitat complexity on resistance to flooding and resilience of stream fish assemblages. Transactions of the American Fisheries Society 121:427-436.

Reice, S. R., R. C. Wissmar, and R. J. Naiman. 1990. Disturbance regimes, resilience, and recovery of animal communities and habitats in lotic ecosystems. Environmental Management 14: 647-659. 
Roghair, C. N., C. A. Dolloff, and M. K. Underwood. 2002. Response of a brook trout population and instream habitat to a catastrophic flood and debris flow. Transactions of the American Fisheries Society 131:718-730.

Ross, S. T. 1991. Mechanisms structuring stream fish assemblages: Are there lessons to be learned from introduced species? Environmental Biology of Fishes 30:359-368.

Ross, S. T. and J. A. Baker. 1983. The response of fishes to periodic spring floods in southeastern stream. American Midland Naturalist 109:1-14.

Ross, S. T., W. J. Matthews, and A. A. Echelle. 1985. Persistence of stream fish assemblages: Effects of environmental change. The American Naturalist 126:24-40.

SAS Institute. 1990. SAS/STAT user's guide: volume 2. SAS Institute, Cary, North Carolina.

Schlosser, I. J. 1985. Flow regime, juvenile abundance, and the assemblage structure of stream fishes. Ecology 66:1484-1490.

Seegrist, D. W. and R. Gard. 1972. Effects of floods on trout in Sagehen Creek, California. Transactions of the American Fisheries Society 101:478-482.

Starrett, W.C. 1951. Some factors affecting the abundance of minnows in the Des Moines River, Iowa. Ecology 32:13-27.

Swanson, F. J., S. L. Johnson, S. V. Gregory, and S. A. Acker. 1998. Flood disturbance in a forested mountain landscape. BioScience 48:681-689.

Swift, Ellsworth. 2000. Geology of the New River: Accessed at URL http://www.nps.gov/neri/geology.htm

Thompson, W.L., G.C. White, and C. Gowan. 1998. Monitoring vertebrate populations. Academic Press, Inc., San Diego, California.

Tramer, E. J. 1977. Catastrophic mortality of stream fishes trapped in shrinking pools. American Midland Naturalist 97:469-478.

USEPA (U.S. Environmental Protection Agency). 1997. Environmental Monitoring and Assessment Program - Surface Waters. Field operations and methods for measuring the ecological condition of wadeable streams. Office of Research and Development, Cincinnati, Ohio.

White, G. C., and K. P. Burnham. 1999. Program MARK: survival estimation from populations of marked animals. Bird Study 46 Supplement:120-138. 
Table 1. Study streams located within the New River Gorge National River (reference streams are asterisked). Slope estimates are for study reaches, not entire streams.

\begin{tabular}{lcccccc}
\multicolumn{1}{c}{ Stream Name } & $\begin{array}{c}\text { Watershed, } \\
\text { hectares }\end{array}$ & Stream Order & $\begin{array}{c}\text { Reach } \\
\text { Length, } \mathbf{m}\end{array}$ & $\begin{array}{c}\text { Mean } \\
\text { Wetted } \\
\text { Width, m }\end{array}$ & $\begin{array}{c}\text { Reach } \\
\text { Slope \% }\end{array}$ & $\begin{array}{c}\text { Mean } \\
\text { Substrate, } \\
\text { mm }\end{array}$ \\
\hline Brooks Branch * & 454.0 & 1 & 156 & 2.8 & 1.7 & 97 \\
Buffalo Creek & $1,026.9$ & 3 & 205 & 4.4 & 3.1 & 156 \\
Coal Run & 787.7 & 2 & 165 & 3.6 & 4.6 & 113 \\
Ephriam Creek & $1,382.2$ & 3 & 184 & 3.7 & 2.2 & 135 \\
Farley Creek $*$ & $1,731.4$ & 2 & 222 & 3.3 & 2.2 & 144 \\
Fern Creek & $1,029.4$ & 2 & 150 & 2.4 & 14.7 & 259 \\
Fire Creek & 417.0 & 1 & 162 & - & 7.6 & - \\
Marr Branch & 715.2 & 2 & 150 & 5.6 & 6.7 & 179 \\
Mill Creek $*$ & $1,491.6$ & 2 & 140 & 3.4 & 3.6 & 54 \\
Short Creek & 532.7 & 2 & 130 & 4.3 & 14.7 & 360 \\
Slater Creek & 812.2 & 1 & 151 & 2.0 & 3.4 & 71 \\
Wolf Creek & $4,364.9$ & 3 & 210 & 5.3 & 7.0 & 164 \\
\hline
\end{tabular}


Table 2. Total abundances of native $(\mathrm{N}=$ native, $\mathrm{E}=$ endemic, $\mathrm{NI}=$ native, but possibly introduced $)$ and nonnative $(\mathrm{I}=$ introduced, $\mathrm{IP}=$ probably introduced $)$ species from five sample periods. Origin categories are from Jenkins and Burkhead (1993).

\begin{tabular}{|c|c|c|c|}
\hline Genus species & Common Name & Origin & Abundance \\
\hline \multicolumn{4}{|l|}{ Cyprinidae } \\
\hline Campostoma anomalum & central stoneroller & $\mathrm{N}$ & 1513 \\
\hline Clinostomus funduloides & rosyside dace & $\mathrm{N}$ & 7 \\
\hline Cyprinella galactura & whitetail shiner & IP & 649 \\
\hline Cyprinella spiloptera & spotfin shiner & $\mathrm{N}$ & 7 \\
\hline Luxilus albeolus & white shiner & $\mathrm{NI}$ & 1 \\
\hline Nocomis platyrhinchus & bigmouth chub & $E$ & 45 \\
\hline Pimephales promelas & fathead minnow & 1 & 1 \\
\hline Notropis hudsonius & spottail shiner & IP & 20 \\
\hline Notropis telescopus & telescope shiner & IP & 641 \\
\hline Notropis rubellus & rosyface shiner & $\mathrm{N}$ & 25 \\
\hline Phoxinus oreas & mountain redbelly dace & $\mathrm{N}$ & 10 \\
\hline Rhinicthys atratulus & blacknose dace & $\mathrm{N}$ & 620 \\
\hline Rhinicthys cataractae & longnose dace & $\mathrm{N}$ & 1 \\
\hline Semotilus atromaculatus & creek chub & $\mathrm{N}$ & 249 \\
\hline \multicolumn{4}{|l|}{ Catostomidae } \\
\hline Catostomus commersoni & white sucker & $\mathrm{N}$ & 13 \\
\hline Hypentelium nigricans & northern hogsucker & $\mathrm{N}$ & 18 \\
\hline \multicolumn{4}{|l|}{ Ictaluridae } \\
\hline Ameiurus natalis & yellow bullhead & IP & 1 \\
\hline Pylodictus olivaris & flathead catfish & $\mathrm{N}$ & 1 \\
\hline \multicolumn{4}{|l|}{ Salmonidae } \\
\hline Salvelinus fontinalis & brook trout & $\mathrm{N}$ & 42 \\
\hline Salmo trutta & brown trout & 1 & 16 \\
\hline \multicolumn{4}{|l|}{ Centrarchidae } \\
\hline Ambloplites rupestris & rockbass & 1 & 39 \\
\hline Lepomis cyanellus & green sunfish & $\mathrm{N}$ & 164 \\
\hline Lepomis macrochirus & bluegill & 1 & 54 \\
\hline Lepomis gibbosus & pumpkinseed & 1 & 39 \\
\hline Micropterus dolomieu & smallmouth bass & 1 & 537 \\
\hline Micropterus salmoides & largemouth bass & 1 & 1 \\
\hline \multicolumn{4}{|l|}{ Percidae } \\
\hline Etheostoma caeruleum & rainbow darter & I & 979 \\
\hline Etheostoma variatum & variegate darter & I & 102 \\
\hline Etheostoma blennioides & greenside darter & I & 6 \\
\hline
\end{tabular}




\section{New River Gorge National River, West Virginia}

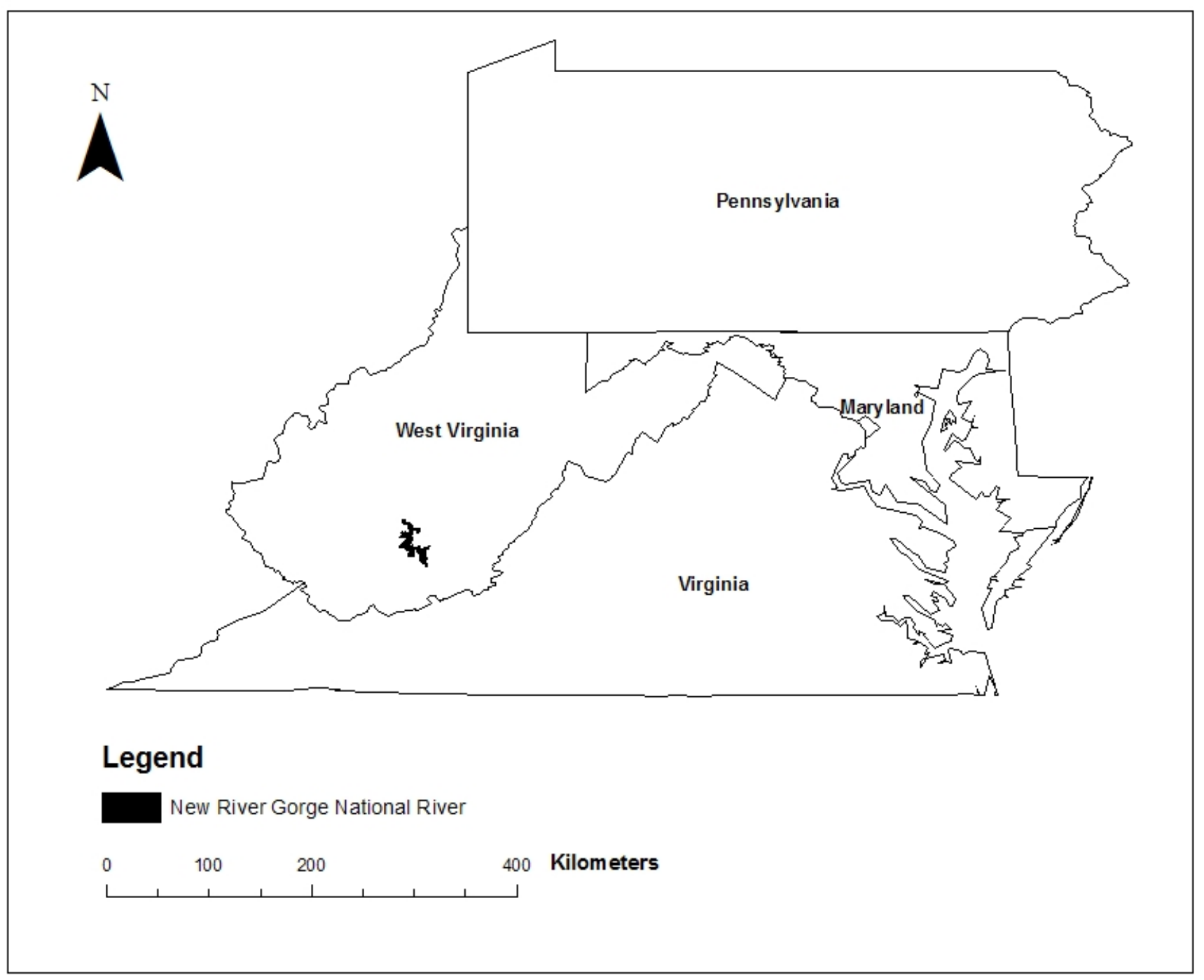

Figure 1. Location of New River Gorge National River in southern West Virginia. 


\section{New River Gorge Recolonization Study Sites}

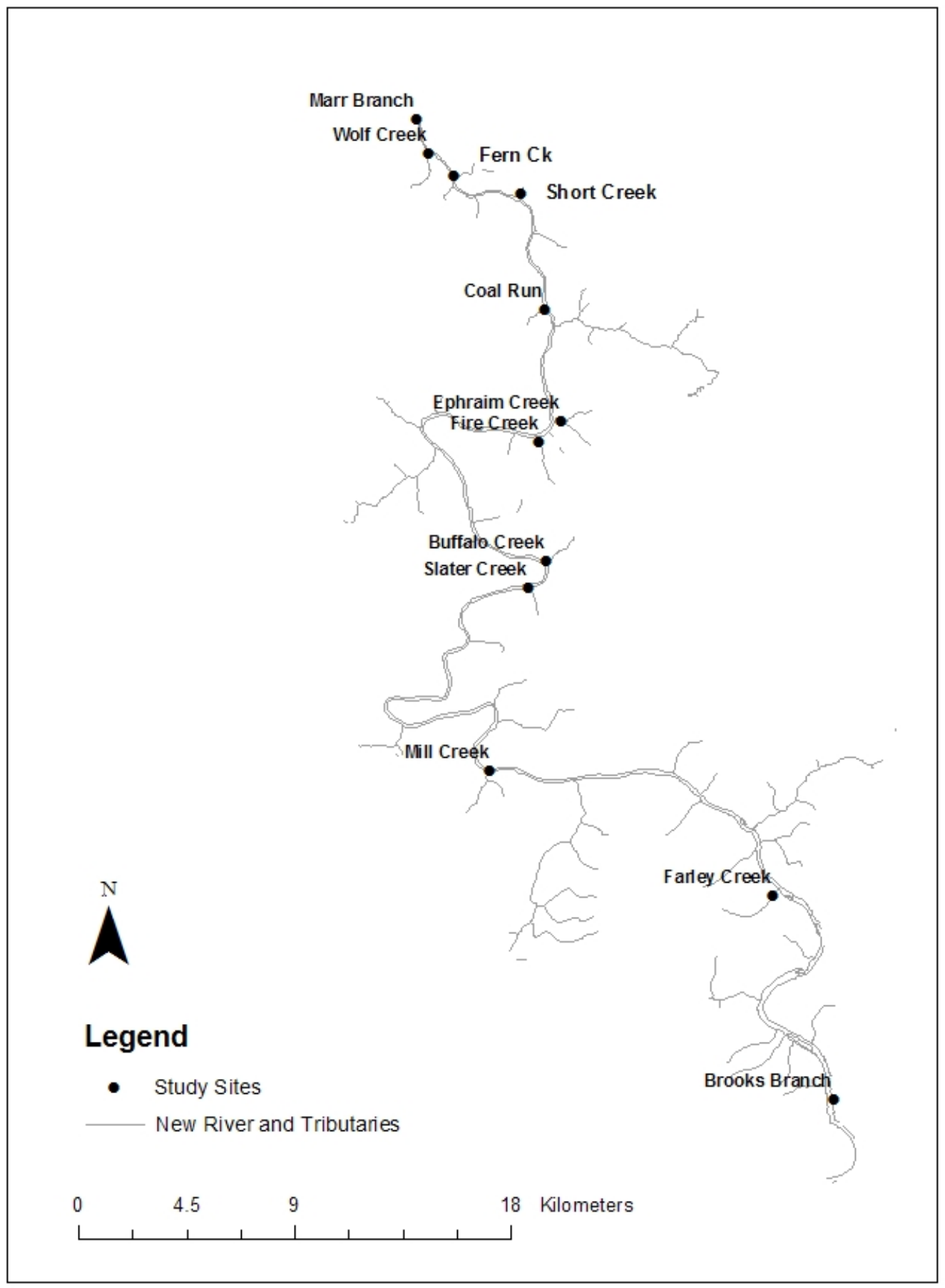

Figure 2. Location of twelve study sites in the New River Gorge National River. 


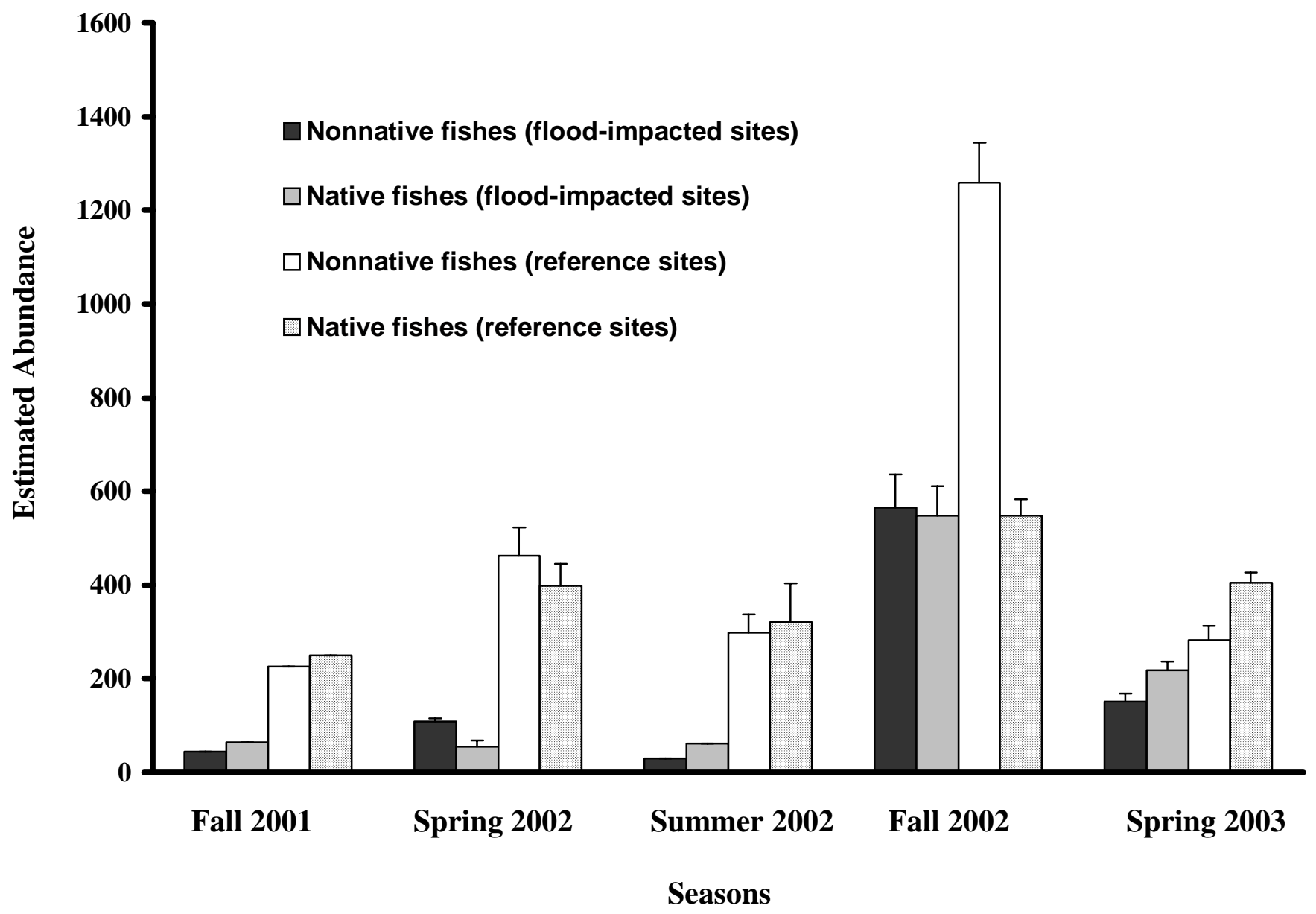

Figure 3. Estimated seasonal abundances of nonnative and native fishes in flood-impacted and reference reaches of tributaries in New River Gorge, West Virginia. Error bars represent upper $95 \%$ confidence intervals from two or three-pass removal estimates; precision was unestimable for single-pass abundance estimates during fall 2001 and flood-impacted sites during summer 2002. 
Nonnative
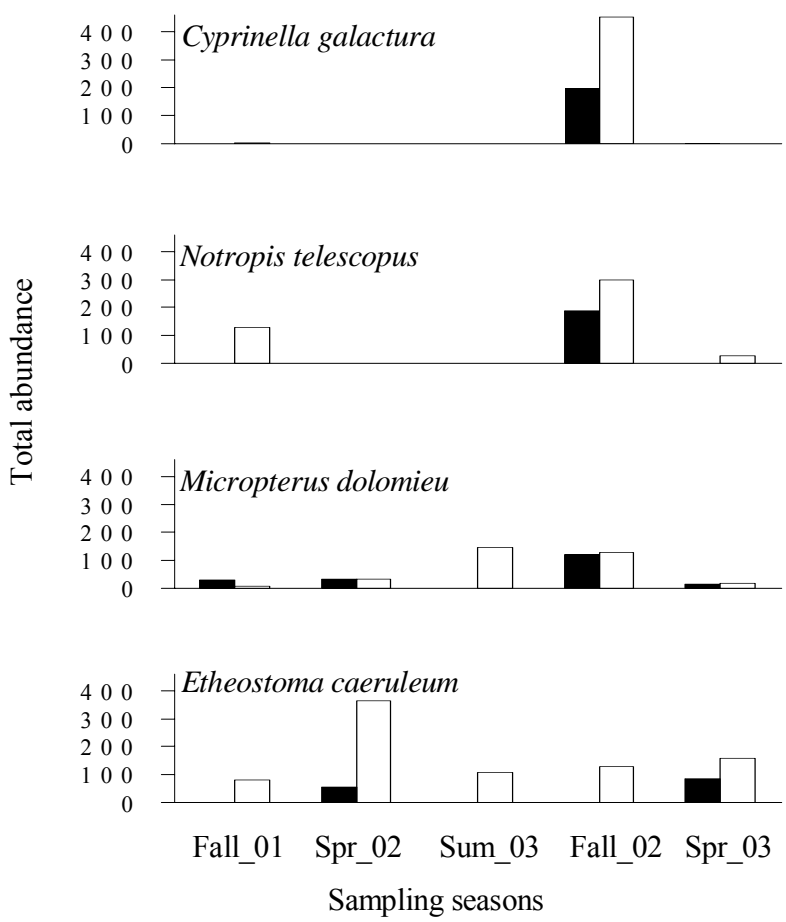

Native
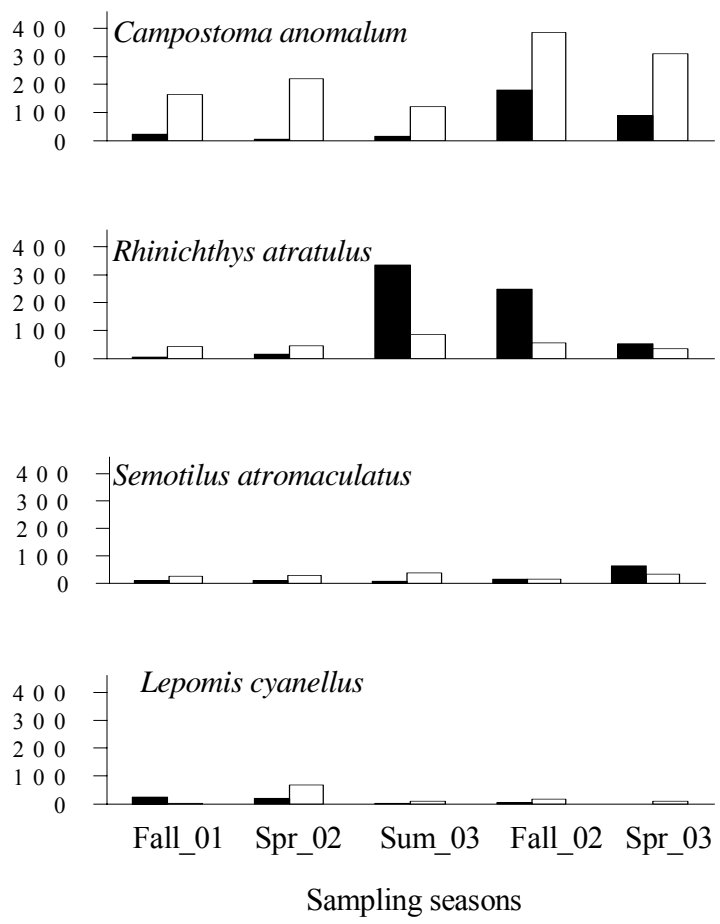

Figure 4. Abundances of dominant nonnative (first column) and native (second column) species in flood-impacted (closed bars) and reference (open bars) reaches of tributaries in New River Gorge, West Virginia, during five consecutive sampling seasons (fall 2001, spring 2002, summer 2002, fall 2002, and spring 2003). 


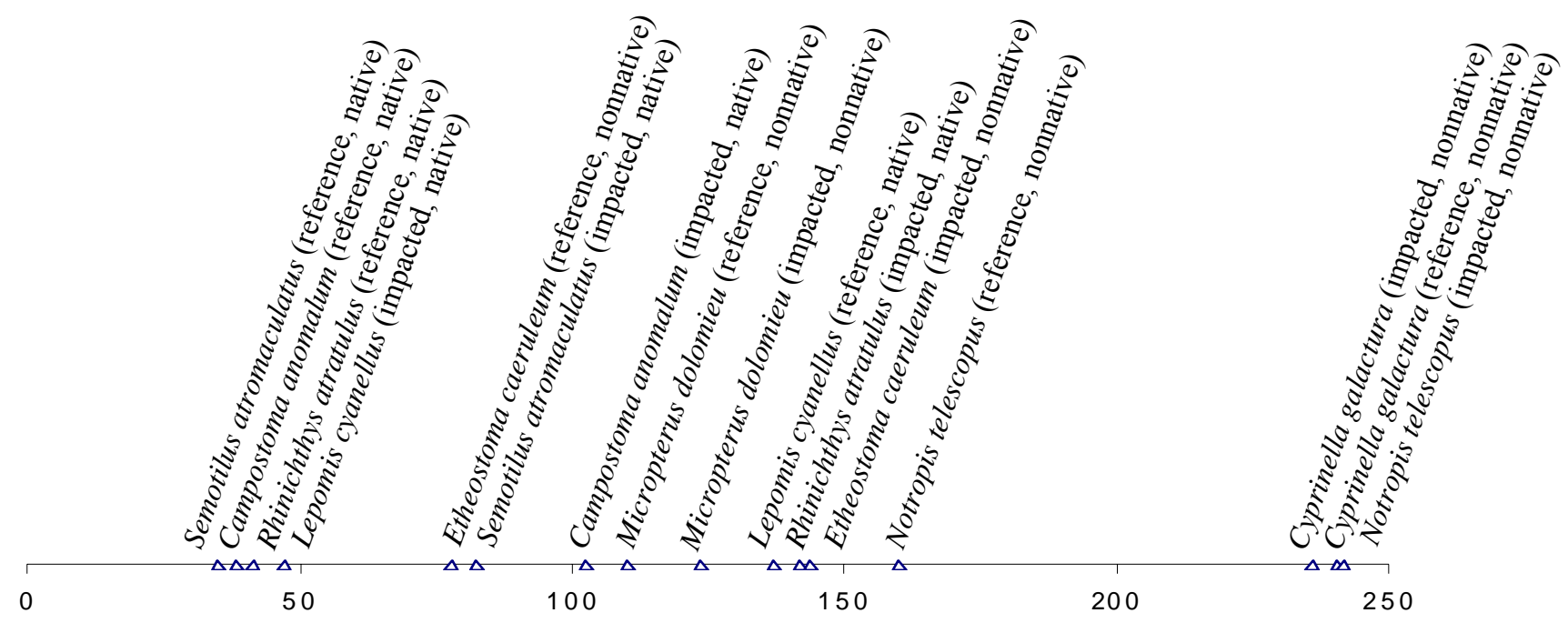

Figure 5. Coefficients of variation (CV; representing an axis of temporal stability) of amongseason abundances of eight common species in tributaries within New River Gorge National River. A CV of zero represents no among-season variation or the highest level of stability. 
Appendix I 

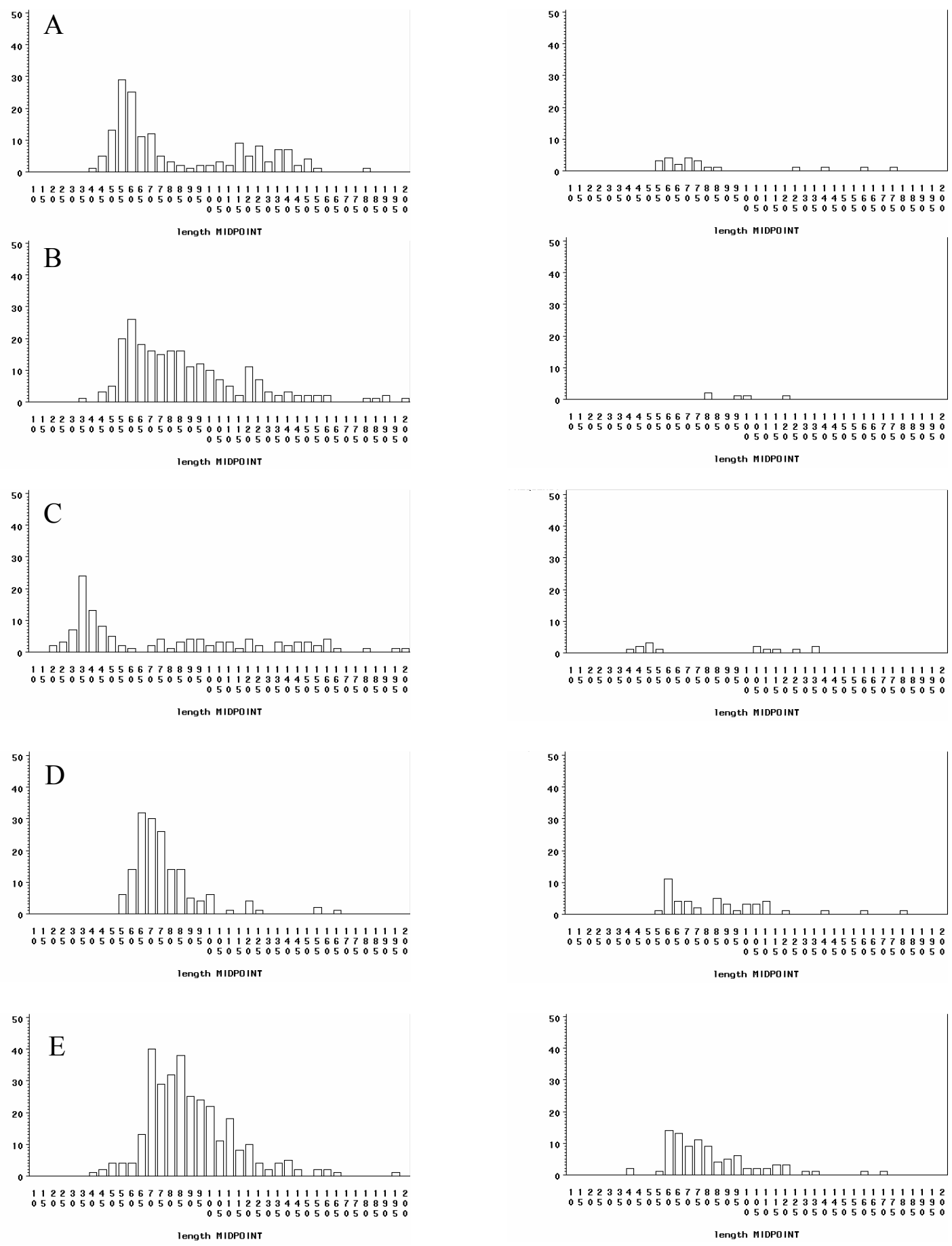

Appendix 1a. Length distributions (5 mm TL groups) of stonerollers from combined reference (left column) and flood-impacted (right column) sites separated by five seasonal sampling periods $(A=$ fall $2001, B=$ spring $2002, C=$ summer $2002, D=$ fall 2002 , and $\mathrm{E}=$ spring 2003). Adults are $60-150 \mathrm{~mm} \mathrm{SL}$ (Jenkins and Burkhead 1994). 

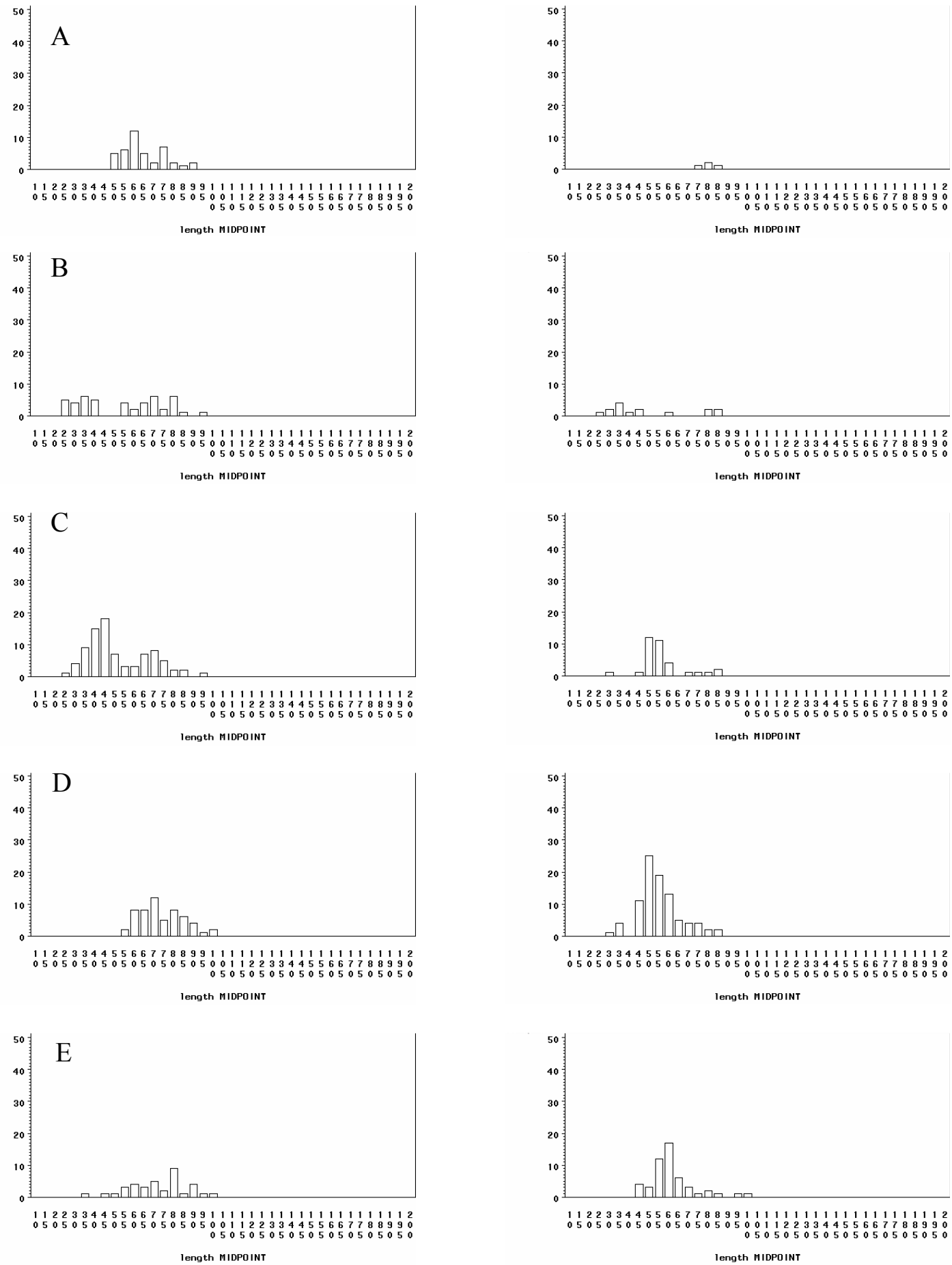

Appendix 1b. Length distributions (5 mm TL groups) of blacknose dace from combined reference (left column) and flood-impacted (right column) sites separated by five seasonal sampling periods $(\mathrm{A}=$ fall $2001, \mathrm{~B}=$ spring $2002, \mathrm{C}=$ summer $2002, \mathrm{D}=$ fall 2002 , and $\mathrm{E}=$ spring 2003). Adults are $40-70$ mm SL (Jenkins and Burkhead 1994). 

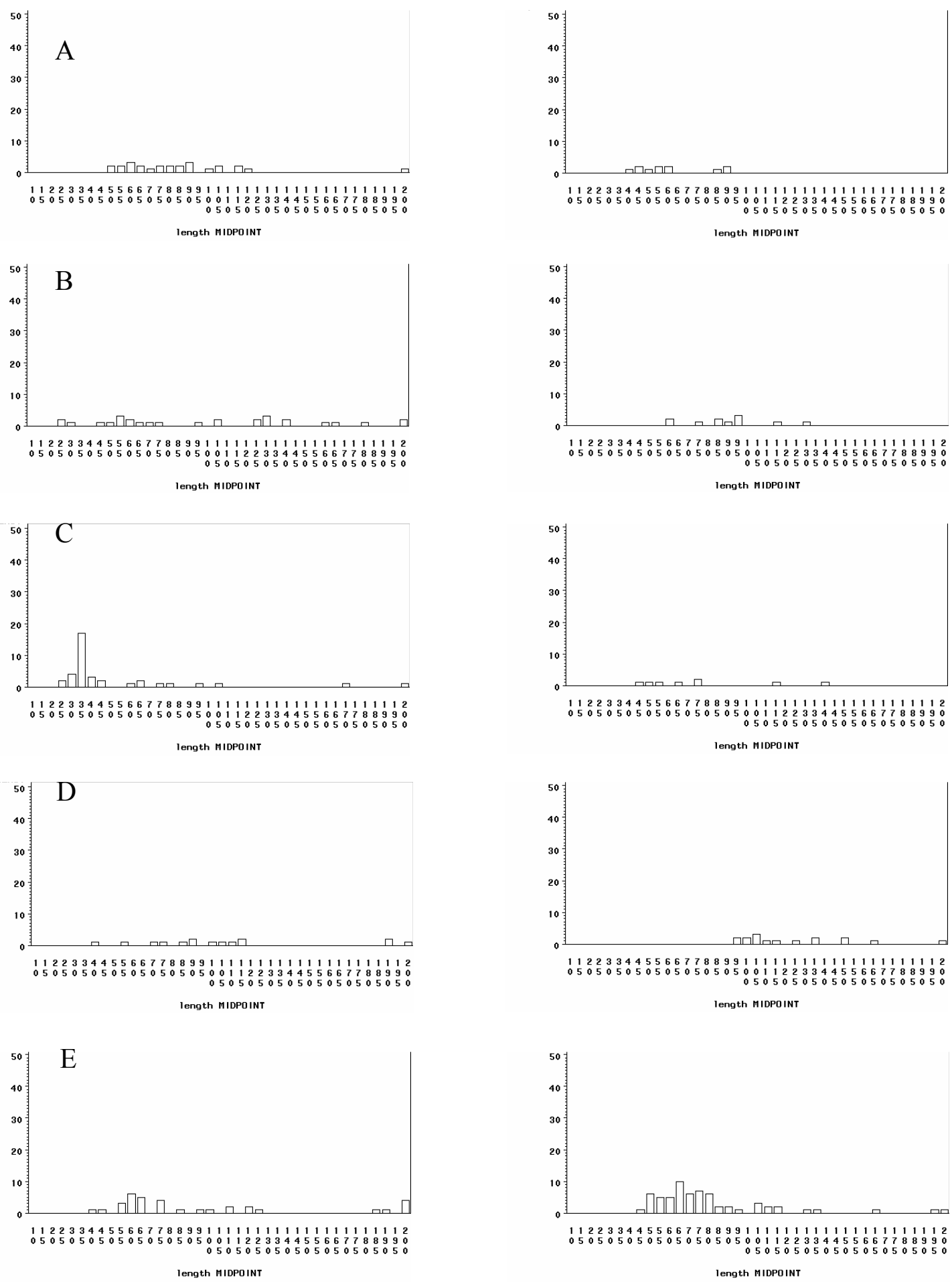

Appendix 1c. Length distributions (5 mm TL groups) of creek chubs from combined reference (left column) and flood-impacted (right column) sites separated by five seasonal sampling periods $(A=$ fall $2001, B=$ spring $2002, C=$ summer $2002, D=$ fall 2002 , and $\mathrm{E}=$ spring 2003). Adults are $80-200 \mathrm{~mm}$ TL (Jenkins and Burkhead 1994). 

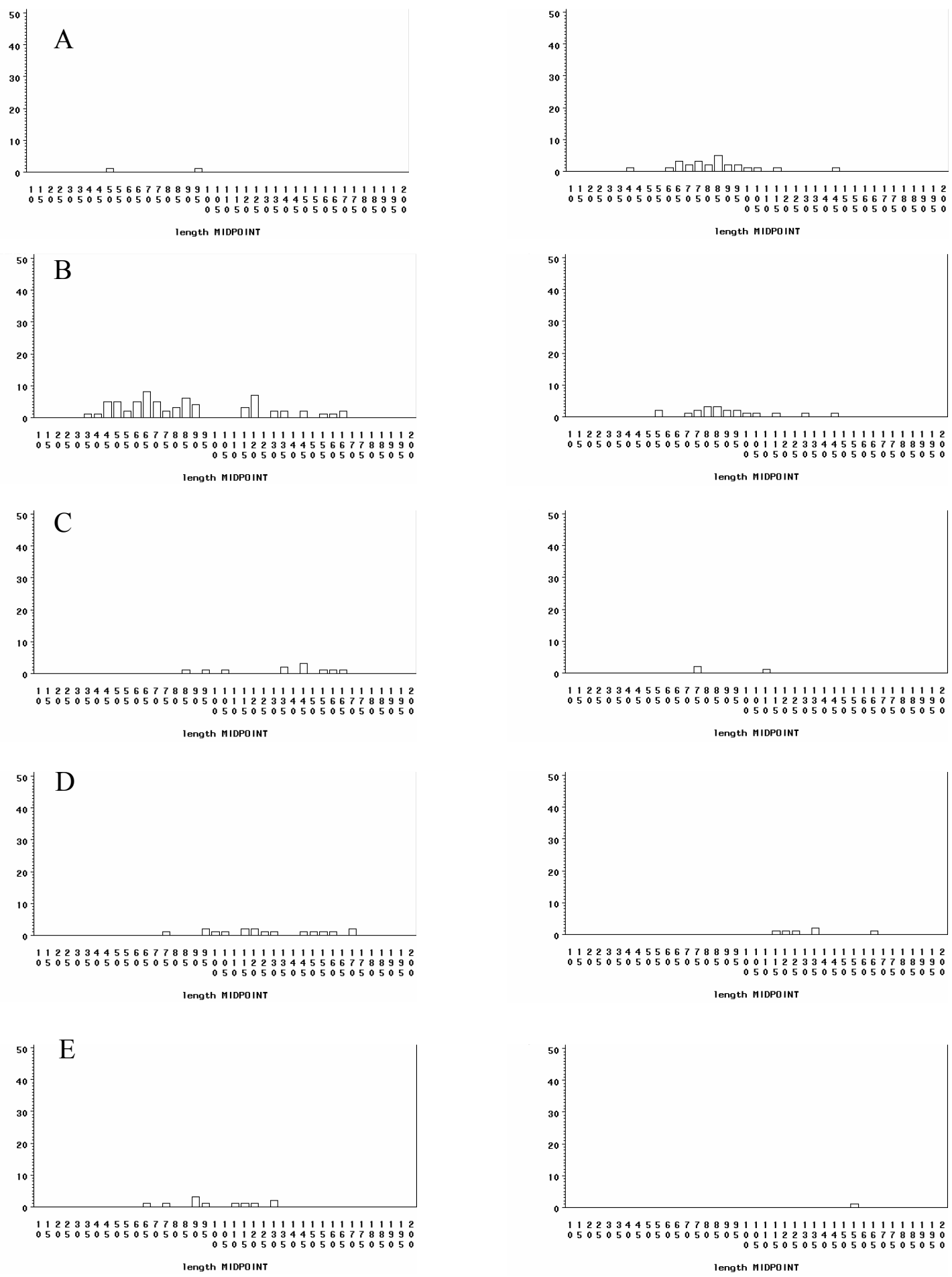

Appendix 1d. Length distributions (5 mm TL groups) of green sunfish from combined reference (left column) and flood-impacted (right column) sites separated by five seasonal sampling periods $(\mathrm{A}=$ fall $2001, \mathrm{~B}=$ spring $2002, \mathrm{C}=$ summer $2002, \mathrm{D}=$ fall 2002 , and $\mathrm{E}=$ spring 2003). Adults are $70-180 \mathrm{~mm}$ TL (Jenkins and Burkhead 1994). 

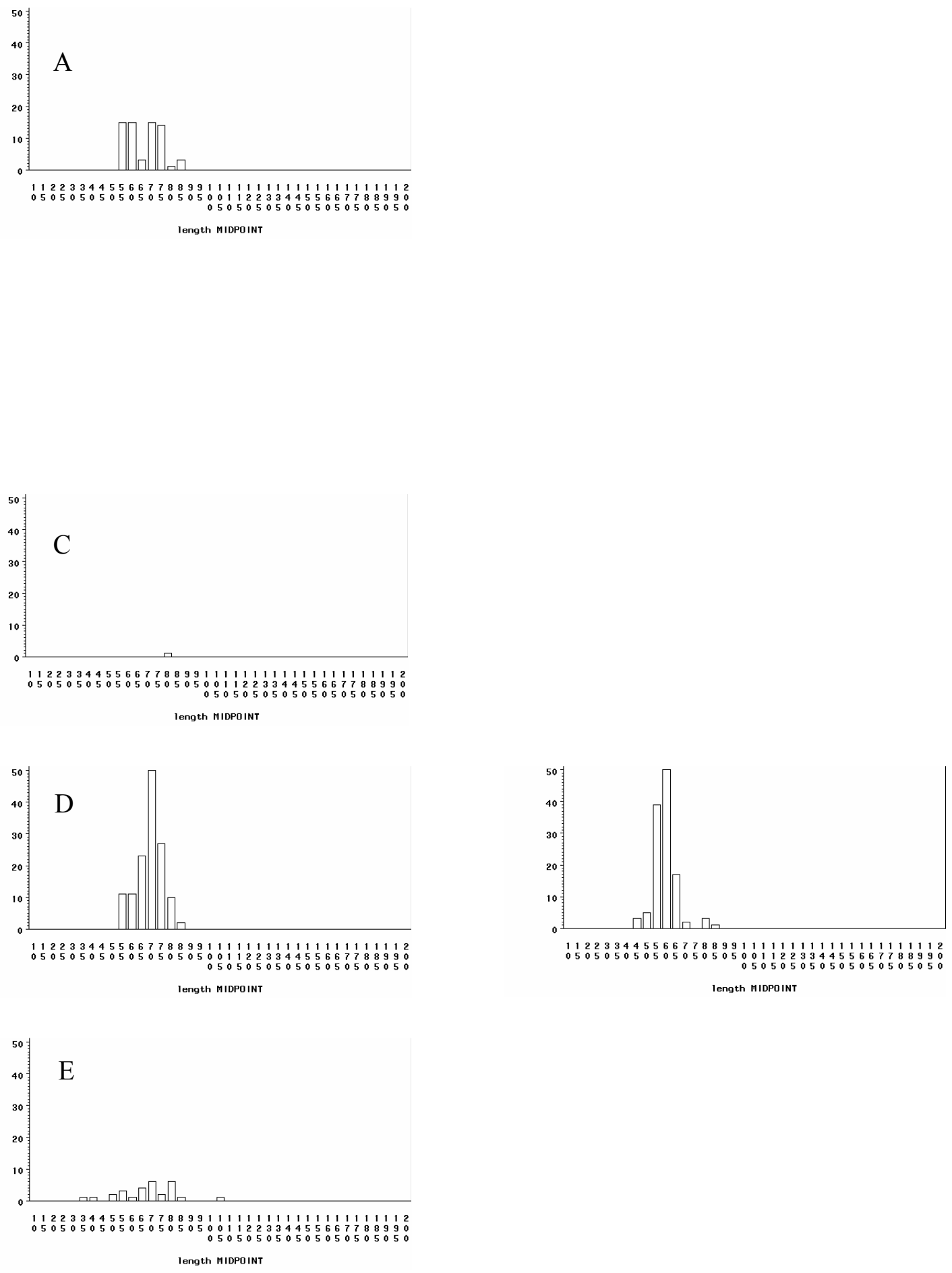

Appendix 1e. Length distributions (5 mm TL groups) of whitetail shiners from combined reference (left column) and flood-impacted (right column) sites separated by five seasonal sampling periods $(A=$ fall $2001, B=$ spring $2002, C=$ summer $2002, D=$ fall 2002 , and $\mathrm{E}=$ spring 2003). Adults are $50-100 \mathrm{~mm} \mathrm{SL}$ (Jenkins and Burkhead 1994). 

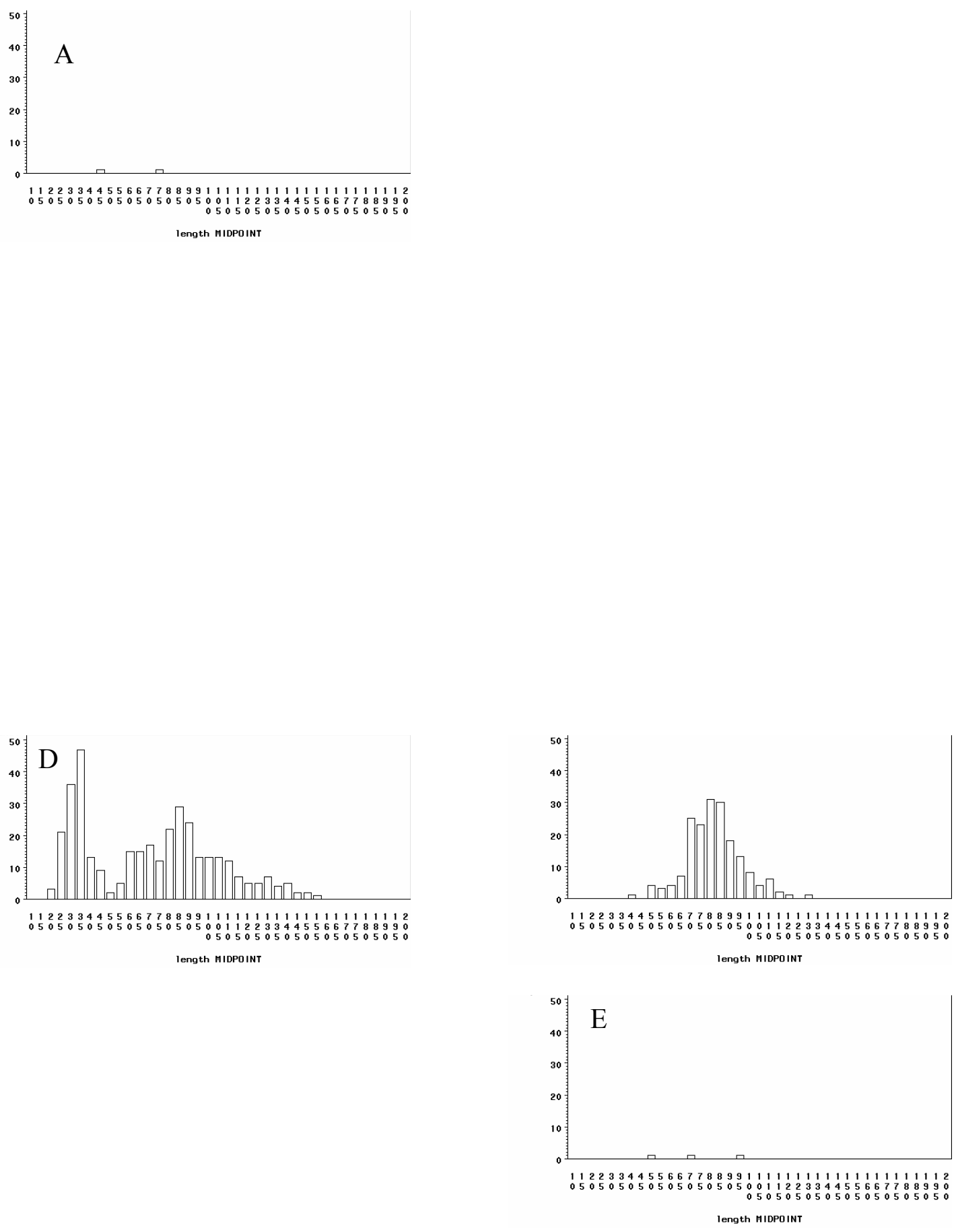

Appendix 1f. Length distributions ( $5 \mathrm{~mm}$ TL groups) of telescope shiners from combined reference (left column) and flood-impacted (right column) sites separated by five seasonal sampling periods $(A=$ fall $2001, B=$ spring $2002, C=$ summer $2002, D=$ fall 2002 , and $\mathrm{E}=$ spring 2003). Adults are $45-60 \mathrm{~mm} \mathrm{SL} \mathrm{(Jenkins} \mathrm{and} \mathrm{Burkhead} \mathrm{1994).}$ 

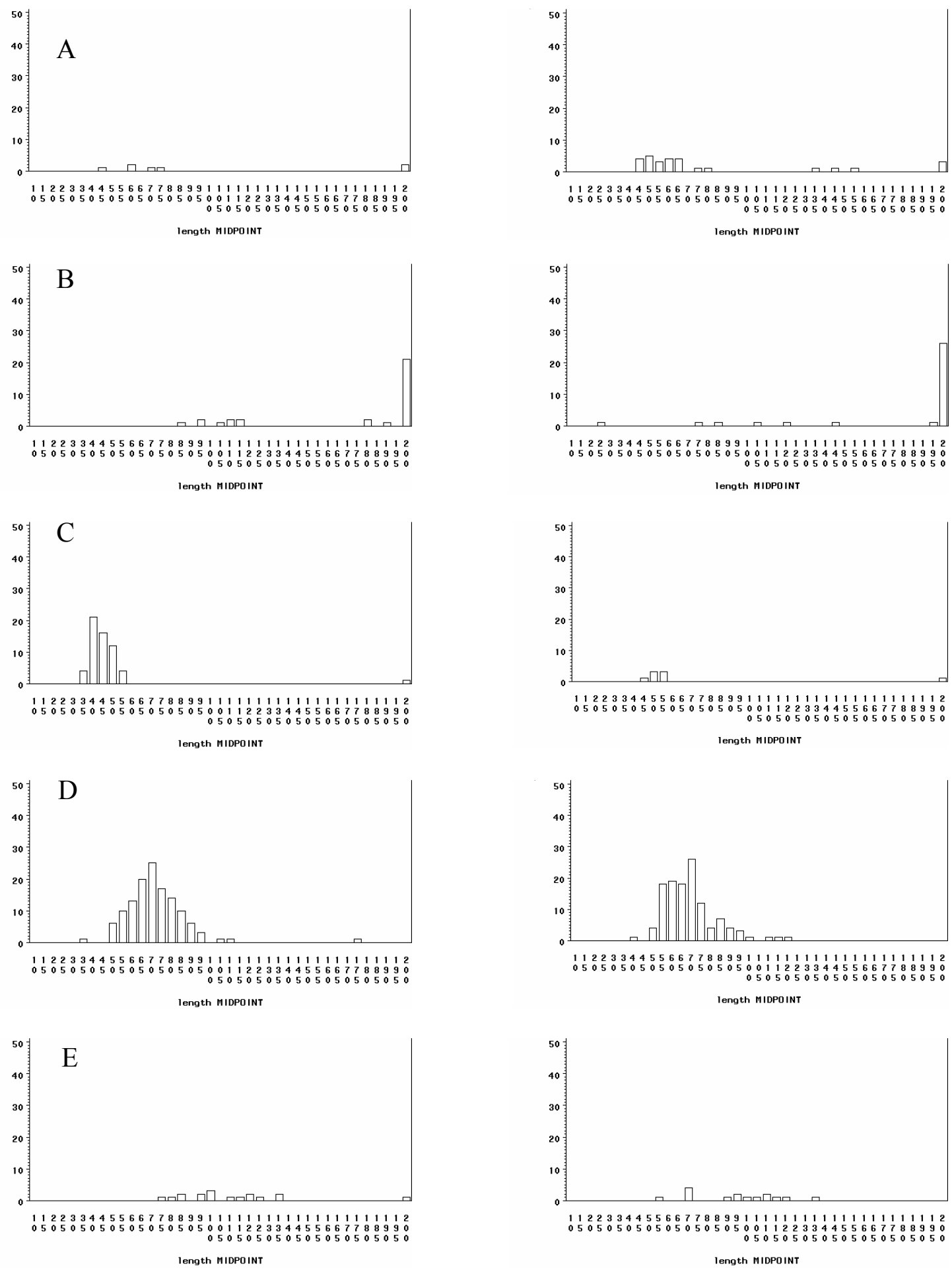

Appendix 1g. Length distributions ( $5 \mathrm{~mm}$ TL groups) of smallmouth bass from combined reference (left column) and flood-impacted (right column) sites separated by five seasonal sampling periods ( $\mathrm{A}=$ fall $2001, \mathrm{~B}=$ spring $2002, \mathrm{C}=$ summer $2002, \mathrm{D}=$ fall 2002 , and $\mathrm{E}=$ spring 2003). Adults are $200-430 \mathrm{~mm}$ TL (Jenkins and Burkhead 1994). 


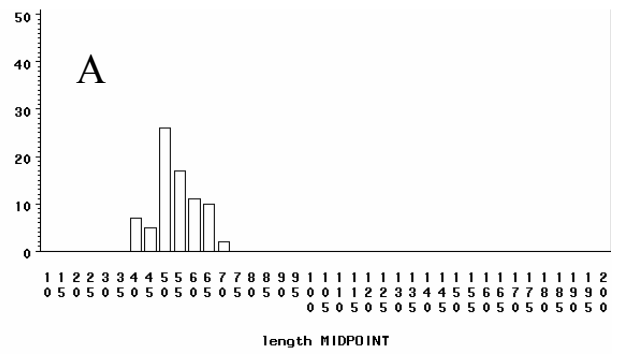

B
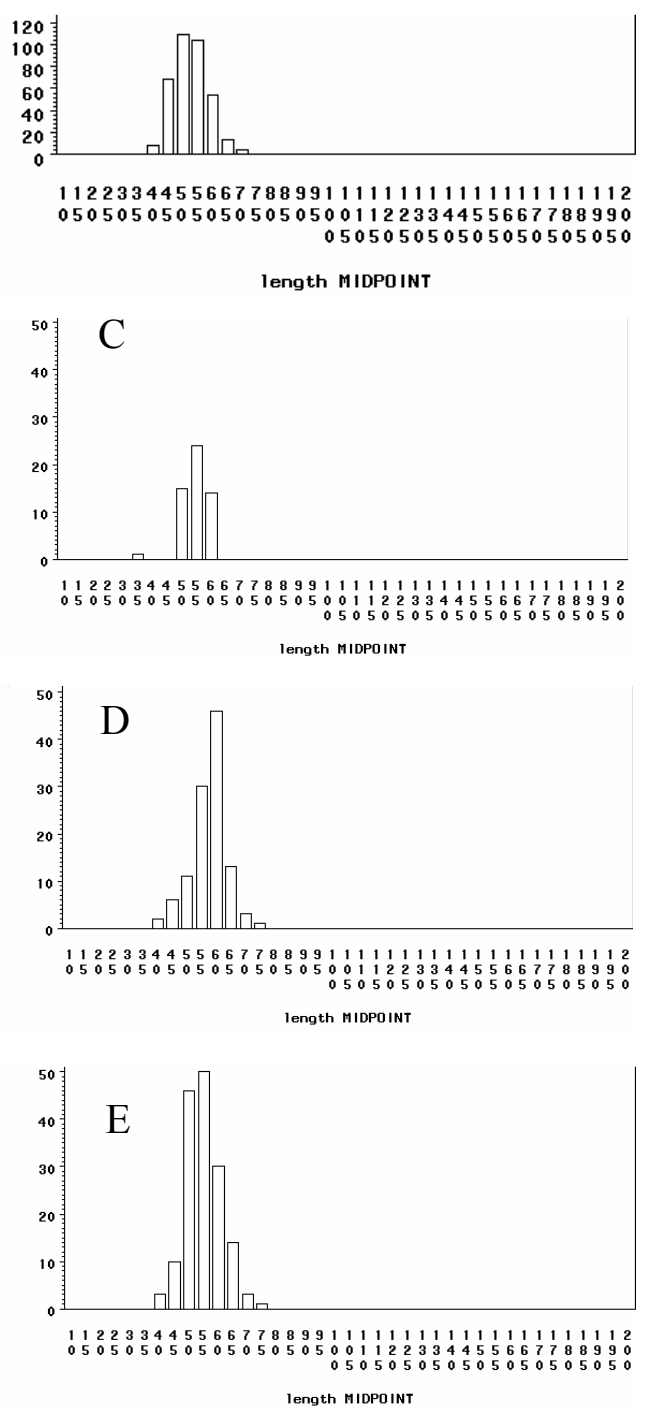
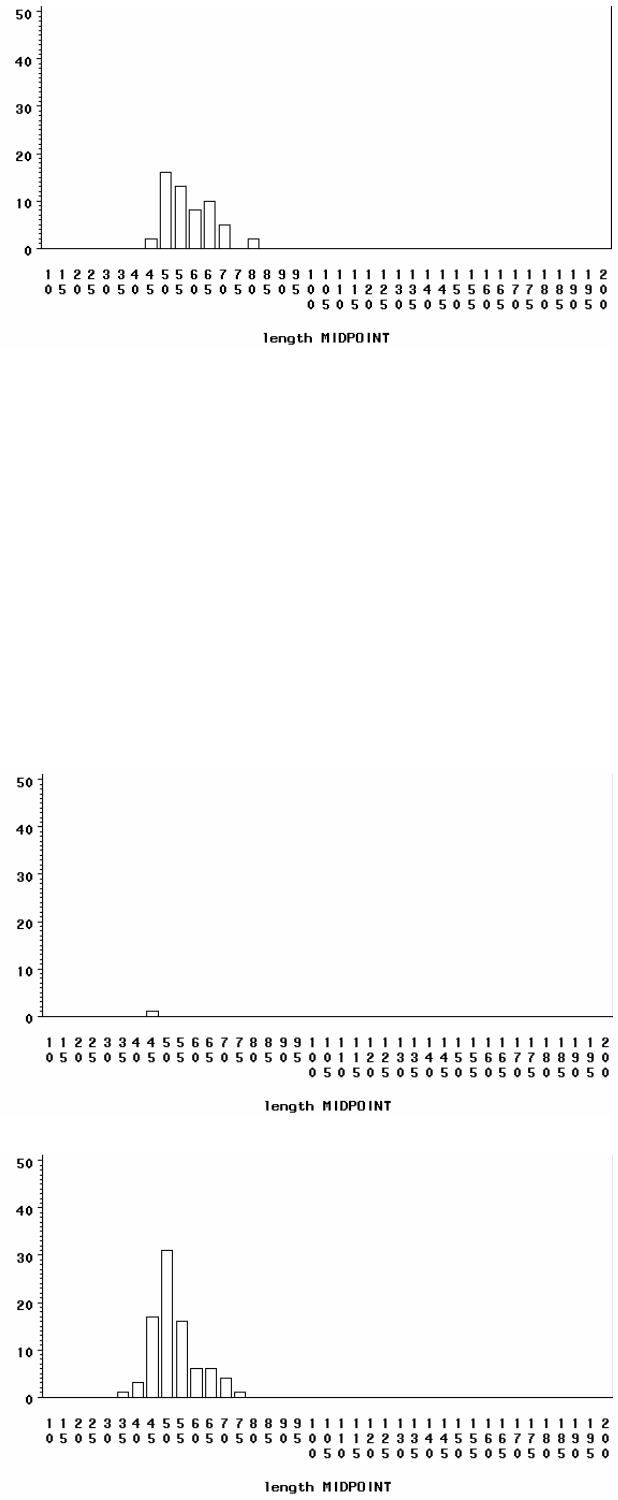

Appendix 1h. Length distributions (5 mm TL groups) of rainbow darters from combined reference (left column) and flood-impacted (right column) sites separated by five seasonal sampling periods $(A=$ fall $2001, B=$ spring $2002, C=$ summer $2002, D=$ fall 2002 , and $\mathrm{E}=$ spring 2003). Adults are $35-50 \mathrm{~mm}$ SL (Jenkins and Burkhead 1994). 
Appendix II 


\section{New River Gorge National River Fish Data}

\section{Brooks Branch}

Seasons

\begin{tabular}{|c|c|c|c|c|c|c|c|}
\hline Species & Common Name & $\begin{array}{l}\text { Fall } \\
2001\end{array}$ & $\begin{array}{c}\text { Spring } \\
2002\end{array}$ & $\begin{array}{c}\text { Summer } \\
2002\end{array}$ & $\begin{array}{l}\text { Fall } \\
2002\end{array}$ & $\begin{array}{c}\text { Spring } \\
2003 \\
\end{array}$ & Total \\
\hline \multicolumn{8}{|l|}{ Cyprinidae } \\
\hline Campostoma anomalum & central stoneroller & 85 & 173 & 78 & 185 & 219 & 740 \\
\hline Cyprinella galactura & whitetail shiner & 2 & 0 & 0 & 237 & 0 & 239 \\
\hline Cyprinella spiloptera & spoffin shiner & 0 & 0 & 0 & 7 & 0 & 7 \\
\hline Nocomis platyrhyncus & bigmouth chub & 3 & 4 & 19 & 0 & 0 & 26 \\
\hline Notropis hudsonius & spottail shiner & 0 & 0 & 0 & 0 & 18 & 18 \\
\hline Notropis rubellus & rosyface shiner & 0 & 0 & 1 & 0 & 0 & 1 \\
\hline Notropis telescopus & telescope shiner & 14 & 0 & 0 & 20 & 22 & 56 \\
\hline Phoxinus oreas & mountain redbelly dace & 4 & 3 & 0 & 0 & 0 & 7 \\
\hline Rhinycthys atratulus & blacknose dace & 6 & 0 & 25 & 1 & 0 & 32 \\
\hline Semotilus atromaculatus & creek chub & 4 & 9 & 31 & 3 & 3 & 50 \\
\hline \multicolumn{8}{|l|}{ Catostomidae } \\
\hline Catastomis commersoni & white sucker & 0 & 0 & 2 & 0 & 0 & 2 \\
\hline Hypentilium nigricans & northern hogsucker & 0 & 0 & 3 & 0 & 0 & 3 \\
\hline \multicolumn{8}{|l|}{ Ictaluridae } \\
\hline Ameirus natalis & yellow bullhead & 0 & 0 & 1 & 0 & 0 & 1 \\
\hline \multicolumn{8}{|l|}{ Centrachidae } \\
\hline Ambloplites rupestris & rock bass & 6 & 6 & 1 & 41 & 23 & 77 \\
\hline Lepomis cyanellus & green sunfish & 2 & 44 & 1 & 0 & 4 & 51 \\
\hline Lepomis gibbosus & pumpkinseed & 0 & 0 & 0 & 32 & 1 & 33 \\
\hline Lepomis macrochirus & bluegill & 0 & 0 & 0 & 52 & 0 & 52 \\
\hline Micropterus dolomieu & smallmouth bass & 1 & 3 & 247 & 64 & 15 & 330 \\
\hline Micropterus punctulatus & spotted bass & 1 & 0 & 0 & 0 & 0 & 1 \\
\hline \multicolumn{8}{|l|}{ Percidae } \\
\hline Etheostoma caeruleum & rainbow darter & 39 & 208 & 4 & 10 & 37 & 298 \\
\hline & Total & 167 & 450 & 413 & 652 & 342 & 2024 \\
\hline
\end{tabular}




\section{New River Gorge National River Fish Data}

\section{Buffalo Creek}

Seasons

\begin{tabular}{|c|c|c|c|c|c|c|c|}
\hline Species & Common Name & $\begin{array}{c}\text { Fall } \\
2001 \\
\end{array}$ & $\begin{array}{c}\text { Spring } \\
2002\end{array}$ & $\begin{array}{c}\text { Summer } \\
2002 \\
\end{array}$ & $\begin{array}{c}\text { Fall } \\
2002 \\
\end{array}$ & $\begin{array}{c}\text { Spring } \\
2003\end{array}$ & Total \\
\hline \multicolumn{8}{|l|}{ Cyprinidae } \\
\hline Campostoma anomalum & central stoneroller & 0 & 2 & 8 & 178 & 44 & 232 \\
\hline Nocomis platyrhynus & bigmouth chub & 0 & 0 & 0 & 2 & 0 & 2 \\
\hline Rhinichthys atratulus & blacknose dace & 0 & 0 & 9 & 2 & 0 & 11 \\
\hline \multicolumn{8}{|l|}{ Catostomidae } \\
\hline Catostomus commersoni & white sucker & 1 & 0 & 0 & 0 & 0 & 1 \\
\hline Hypentilium nigricans & northern hogsucker & 0 & 0 & 0 & 1 & 0 & 1 \\
\hline \multicolumn{8}{|l|}{ Salmonidae } \\
\hline Salmo trutta & brown trout & 1 & 1 & 0 & 0 & 6 & 8 \\
\hline Salvelinus fontinalis & brook trout & 6 & 2 & 13 & 7 & 2 & 30 \\
\hline Semotilus atromaculatus & creek chub & 1 & 0 & 0 & 0 & 0 & 1 \\
\hline \multicolumn{8}{|l|}{ Centrarchida } \\
\hline Ambloplites rupestris & rockbass & 0 & 2 & 0 & 0 & 0 & 2 \\
\hline Micropterus dolomieu & smallmouth bass & 11 & 4 & 3 & 25 & 4 & 47 \\
\hline \multicolumn{8}{|l|}{ Percidae } \\
\hline Etheostoma blennioides & greenside darter & 0 & 0 & 0 & 0 & 1 & 1 \\
\hline Etheostoma caeruleum & rainbow darter & 0 & 36 & 0 & 1 & 64 & 101 \\
\hline \multirow[t]{2}{*}{ Etheostoma variatum } & variegate darter & 1 & 1 & 0 & 0 & 9 & 11 \\
\hline & Total & 21 & 48 & 33 & 216 & 130 & 448 \\
\hline
\end{tabular}




\section{New River Gorge National River Fish Data}

\section{Coal Run}

\section{Seasons}

\begin{tabular}{|c|c|c|c|c|c|c|c|}
\hline Species & Common Name & $\begin{array}{l}\text { Fall } \\
2001 \\
\end{array}$ & $\begin{array}{c}\text { Spring } \\
2002 \\
\end{array}$ & $\begin{array}{c}\text { Summer } \\
2002 \\
\end{array}$ & $\begin{array}{l}\text { Fall } \\
2002 \\
\end{array}$ & $\begin{array}{c}\text { Spring } \\
2003 \\
\end{array}$ & Total \\
\hline \multicolumn{8}{|l|}{ Cyprinidae } \\
\hline Campostoma anomalum & central stoneroller & 3 & 1 & 3 & 5 & 8 & 20 \\
\hline Cyprinella galactura & whitetail shiner & 0 & 0 & 0 & 4 & 1 & 5 \\
\hline Nocomis platyrhyncus & bigmouth chub & 0 & 0 & 0 & 1 & 1 & 2 \\
\hline Rhinicthys atratulus & blacknose dace & 1 & 3 & 2 & 21 & 12 & 39 \\
\hline Semotilus atromaculatus & creek chub & 0 & 2 & 1 & 11 & 26 & 40 \\
\hline \multicolumn{8}{|l|}{ Catostomidae } \\
\hline Hypentilium nigricans & northern hogsucker & 0 & 0 & 0 & 2 & 0 & 2 \\
\hline \multicolumn{8}{|l|}{ Centrarchidae } \\
\hline Lepomis cyanellus & green sunfish & 3 & 1 & 1 & 2 & 0 & 7 \\
\hline Micropterus dolomieu & smallmouth bass & 10 & 2 & 0 & 10 & 4 & 26 \\
\hline \multicolumn{8}{|l|}{ Percidae } \\
\hline Etheostoma caeruleum & rainbow darter & 0 & 0 & 0 & 0 & 5 & 5 \\
\hline Etheostoma variatum & variegate darter & 0 & 0 & 0 & 0 & 3 & 3 \\
\hline & & & & & & & \\
\hline & & & & & & & \\
\hline & & & & & & & \\
\hline & & & & & & & \\
\hline & & & & & & & \\
\hline & & & & & & & \\
\hline & Total & 19 & 9 & 7 & 56 & 60 & 149 \\
\hline
\end{tabular}




\section{New River Gorge National River Fish Data}

\section{Eprhiam Creek}

Seasons

\begin{tabular}{|c|c|c|c|c|c|c|c|}
\hline Species & Common Name & $\begin{array}{c}\text { Fall } \\
2001\end{array}$ & $\begin{array}{c}\text { Spring } \\
2002 \\
\end{array}$ & $\begin{array}{c}\text { Summer } \\
2002 \\
\end{array}$ & $\begin{array}{c}\text { Fall } \\
2002 \\
\end{array}$ & $\begin{array}{c}\text { Spring } \\
2003\end{array}$ & Total \\
\hline \multicolumn{8}{|l|}{ Cyrpinidae } \\
\hline Campostoma anomalum & stoneroller & 0 & 0 & 0 & 0 & 9 & 9 \\
\hline Clinostomus funduloides & rosyside dace & 0 & 1 & 0 & 0 & 0 & 1 \\
\hline Rhinychthys atratulus & blacknose dace & 0 & 1 & 0 & 0 & 0 & 1 \\
\hline Semotilus atromaculatis & creek chub & 0 & 0 & 0 & 0 & 2 & 2 \\
\hline Micropterus dolomieu & smallmouth bass & 0 & 3 & 0 & 7 & 1 & 11 \\
\hline \multicolumn{8}{|l|}{ Percidae } \\
\hline Etheostoma caeruleum & rainbow darter & 0 & 3 & 0 & 0 & 1 & 4 \\
\hline \multirow[t]{2}{*}{ Etheostoma variatum } & variegate darter & 0 & 0 & 0 & 0 & 15 & 15 \\
\hline & Total & 0 & 8 & 0 & 7 & 28 & 43 \\
\hline
\end{tabular}




\section{New River Gorge National River Fish Data}

\section{Farley Creek}

\begin{tabular}{|c|c|c|c|c|c|c|c|}
\hline \multirow[b]{2}{*}{ Species } & \multirow[b]{2}{*}{ Common Name } & \multicolumn{5}{|c|}{ Seasons } & \multirow[b]{2}{*}{ Total } \\
\hline & & $\begin{array}{l}\text { Fall } \\
2001 \\
\end{array}$ & $\begin{array}{c}\text { Spring } \\
2002 \\
\end{array}$ & $\begin{array}{c}\text { Summer } \\
2002\end{array}$ & $\begin{array}{r}\text { Fall } \\
2002 \\
\end{array}$ & $\begin{array}{c}\text { Spring } \\
2003 \\
\end{array}$ & \\
\hline \multicolumn{8}{|l|}{ Cyprinidae } \\
\hline Campostom anomalum & central stoneroller & 62 & 35 & 38 & 181 & 131 & 447 \\
\hline Clinostomus funduloides & rosyside dace & 0 & 0 & 3 & 0 & 0 & 3 \\
\hline Cyprinella galactura & whitetail shiner & 0 & 0 & 0 & 149 & 0 & 149 \\
\hline Notropis hudsonius & spottail shiner & 0 & 0 & 0 & 0 & 2 & 2 \\
\hline Notropis rubellus & rosyface shiner & 0 & 0 & 0 & 25 & 0 & 25 \\
\hline Notropis telescopis & telescope shiner & 2 & 0 & 0 & 260 & 0 & 262 \\
\hline Phoxinus oreas & mountain redbelly dace & 0 & 0 & 2 & 0 & 1 & 3 \\
\hline Rhinichthys atratulus & blacknose dace & 26 & 42 & 52 & 45 & 26 & 191 \\
\hline Semotilus atromaculatus & creek chub & 1 & 8 & 4 & 6 & 10 & 29 \\
\hline \multicolumn{8}{|l|}{ Catostomidae } \\
\hline Catostomus commersoni & white sucker & 0 & 1 & 0 & 1 & 0 & 2 \\
\hline Hypentilium nigricans & northern hogsucker & 0 & 2 & 0 & 0 & 2 & 4 \\
\hline \multicolumn{8}{|l|}{ Centrarchidae } \\
\hline Lepomis cyanellus & green sunfish & 0 & 14 & 10 & 15 & 6 & 45 \\
\hline Lepomis gibbosus & pumpkinseed & 0 & 0 & 1 & 0 & 0 & 1 \\
\hline Micropterus dolomieu & smallmouth bass & 26 & 20 & 1 & 25 & 1 & 73 \\
\hline \multicolumn{8}{|l|}{ Percidae } \\
\hline Etheostoma blennioides & greenside darter & 0 & 0 & 3 & 0 & 2 & 5 \\
\hline Etheostoma caeruleum & rainbow darter & 60 & 167 & 104 & 112 & 123 & 566 \\
\hline \multirow[t]{2}{*}{ Etheostoma variatum } & variegate darter & 6 & 22 & 13 & 14 & 13 & 68 \\
\hline & Total & 183 & 311 & 231 & 833 & 317 & 1875 \\
\hline
\end{tabular}




\section{New River Gorge National River Fish Data}

\section{Fern Creek}

\section{Seasons}

\begin{tabular}{|l|c|c|c|c|c|c|r|} 
& \multicolumn{2}{c}{ Fall } & \multicolumn{2}{c}{ Spring } & Summer & Fall & Spring \\
Species & Common Name & 2001 & $\mathbf{2 0 0 2}$ & $\mathbf{2 0 0 2}$ & $\mathbf{2 0 0 2}$ & Total \\
\hline Cyprinidae & & & & & & & \\
\hline Semotilus atromaculatus & creek chub & 0 & 0 & 0 & 0 & 2 & 2 \\
\hline
\end{tabular}




\section{New River Gorge National River Fish Data}

\section{Fire Creek}

\begin{tabular}{|c|c|c|c|c|c|c|c|}
\hline \multirow[b]{2}{*}{ Species } & \multirow[b]{2}{*}{ Common Name } & \multicolumn{5}{|c|}{ Seasons } & \multirow[b]{2}{*}{ Total } \\
\hline & & $\begin{array}{r}\text { Fall } \\
2001 \\
\end{array}$ & $\begin{array}{c}\text { Spring } \\
2002 \\
\end{array}$ & $\begin{array}{c}\text { Summer } \\
2002\end{array}$ & $\begin{array}{r}\text { Fall } \\
2002 \\
\end{array}$ & $\begin{array}{c}\text { Spring } \\
2003\end{array}$ & \\
\hline \multicolumn{8}{|l|}{ Cyprinidae } \\
\hline Semotilus atromaculatus & creek chub & 0 & 0 & 0 & 0 & 1 & 1 \\
\hline \multicolumn{8}{|l|}{ Percidae } \\
\hline Etheostoma caeruleum & rainbow darter & 0 & 1 & 0 & 0 & 0 & 1 \\
\hline & Total & 0 & 1 & 0 & 0 & 1 & 2 \\
\hline
\end{tabular}




\section{New River Gorge National River Fish Data}

\section{Marr Branch}

\section{Seasons}

\begin{tabular}{|c|c|c|c|c|c|c|c|}
\hline Species & Common Name & $\begin{array}{l}\text { Fall } \\
2001\end{array}$ & $\begin{array}{c}\text { Spring } \\
2002\end{array}$ & $\begin{array}{c}\text { Summer } \\
2002\end{array}$ & $\begin{array}{l}\text { Fall } \\
2002\end{array}$ & $\begin{array}{c}\text { Spring } \\
2003\end{array}$ & Total \\
\hline \multicolumn{8}{|l|}{ Cyprinidae } \\
\hline Campostoma anomalum & central stoneroller & 4 & 1 & 0 & 1 & 10 & 16 \\
\hline Clinostomus funduloides & rosyside dace & 0 & 1 & 1 & 0 & 0 & 2 \\
\hline Cyprinella galactura & whitetail shiner & 0 & 0 & 0 & 132 & 2 & 134 \\
\hline Luxilus albeolus & white shiner & 0 & 0 & 0 & 0 & 1 & 1 \\
\hline Nocomis platyrhyncus & bigmouth chub & 0 & 0 & 1 & 3 & 1 & 5 \\
\hline Notropis telescopus & telescope shiner & 0 & 0 & 0 & 185 & 0 & 185 \\
\hline Pimephales promelas & fathead minnow & 0 & 0 & 0 & 0 & 1 & 1 \\
\hline Rhinichthys atratulus & blacknose dace & 0 & 3 & 1 & 12 & 2 & 18 \\
\hline Rhinichthys cataractae & longnose dace & 4 & 0 & 0 & 0 & 0 & 4 \\
\hline Semotilus atromaculatus & creek chub & 0 & 1 & 4 & 3 & 11 & 19 \\
\hline \multicolumn{8}{|l|}{ Catostomidae } \\
\hline Catostomus commersoni & white sucker & 0 & 0 & 0 & 7 & 1 & 8 \\
\hline Hypentilium nigricans & northern hogsucker & 0 & 0 & 0 & 1 & 0 & 1 \\
\hline \multicolumn{8}{|l|}{ Salmonidae } \\
\hline Salmo trutta & brown trout & 0 & 0 & 0 & 0 & 1 & 1 \\
\hline Salivinus fontinalus & brook trout & 0 & 1 & 0 & 0 & 0 & 1 \\
\hline \multicolumn{8}{|l|}{ Centrarchidae } \\
\hline Ambloplites rupestris & rock bass & 42 & 0 & 1 & 1 & 0 & 44 \\
\hline Micropterus dolomieu & smallmouth bass & 4 & 5 & 0 & 49 & 5 & 63 \\
\hline Lepomis cyanellus & green sunfish & 0 & 0 & 0 & 0 & 1 & 1 \\
\hline Lepomis macrochirus & bluegill & 0 & 0 & 0 & 0 & 1 & 1 \\
\hline \multicolumn{8}{|l|}{ Percidae } \\
\hline \multirow[t]{2}{*}{ Etheostoma caeruleum } & rainbow darter & 0 & 3 & 0 & 0 & 1 & 4 \\
\hline & Total & 54 & 15 & 8 & 394 & 38 & 509 \\
\hline
\end{tabular}




\section{New River Gorge National River Fish Data}

\section{Mill Creek}

Seasons (Fall 2001 - Spring 2003)

\begin{tabular}{|c|c|c|c|c|c|c|c|}
\hline Species & Common Name & $\begin{array}{r}\text { Fall } \\
2001 \\
\end{array}$ & $\begin{array}{c}\text { Spring } \\
2002 \\
\end{array}$ & $\begin{array}{c}\text { Summer } \\
2002 \\
\end{array}$ & $\begin{array}{l}\text { Fall } \\
2002 \\
\end{array}$ & $\begin{array}{c}\text { Spring } \\
2003 \\
\end{array}$ & Total \\
\hline \multicolumn{8}{|l|}{ Cyprinidae } \\
\hline Campostoma anomalum & central stoneroller & 32 & 15 & 0 & 13 & 7 & 67 \\
\hline Clinostomus funduloides & rosyside dace & 3 & 0 & 0 & 0 & 0 & 3 \\
\hline Cyprinella galactura & whitetail shiner & 0 & 0 & 0 & 59 & 0 & 59 \\
\hline Nocomis platyrhyncus & bigmouth chub & 4 & 0 & 6 & 0 & 0 & 10 \\
\hline Notropis telescopus & telescope shiner & 113 & 0 & 1 & 19 & 7 & 140 \\
\hline Rhinichthys atratulus & blacknose dace & 12 & 4 & 8 & 9 & 10 & 43 \\
\hline Semotilus atromaculatus & creek chub & 21 & 11 & 2 & 6 & 21 & 61 \\
\hline \multicolumn{8}{|l|}{ Catostomidae } \\
\hline Hypentilium nigricans & northern hogsucker & 1 & 0 & 2 & 1 & 0 & 4 \\
\hline \multicolumn{8}{|l|}{ Salmonidae } \\
\hline Salmo trutta & brown trout & 0 & 1 & 1 & 1 & 1 & 4 \\
\hline Salvelinus fontinalis & brook trout & 1 & 3 & 1 & 0 & 5 & 10 \\
\hline \multicolumn{8}{|l|}{ Centrarchida } \\
\hline Lepomis cyanellus & green sunfish & 0 & 10 & 0 & 2 & 1 & 13 \\
\hline Micropterus dolomieu & smallmouth bass & 3 & 0 & 2 & 0 & 1 & 6 \\
\hline Micropterus dolomieu & smallmouth bass & 0 & 9 & 0 & 39 & 0 & 48 \\
\hline \multicolumn{8}{|l|}{ Percidae } \\
\hline \multirow[t]{2}{*}{ Etheostoma caeruleum } & rainbow darter & 5 & 6 & 0 & 5 & 6 & 22 \\
\hline & Total & 195 & 59 & 23 & 154 & 59 & 490 \\
\hline
\end{tabular}




\section{New River Gorge National River Fish Data}

\section{Slater Creek}

Seasons

\begin{tabular}{|c|c|c|c|c|c|c|c|}
\hline Species & Common Name & $\begin{array}{l}\text { Fall } \\
2001 \\
\end{array}$ & $\begin{array}{c}\text { Spring } \\
2002\end{array}$ & $\begin{array}{c}\text { Summer } \\
2002\end{array}$ & $\begin{array}{l}\text { Fall } \\
2002\end{array}$ & $\begin{array}{c}\text { Spring } \\
2003\end{array}$ & Total \\
\hline \multicolumn{8}{|l|}{ Cyprinidae } \\
\hline Campostoma anomalum & central stoneroller & 8 & 1 & 0 & 27 & 18 & 54 \\
\hline Cyprinella galactura & whitetail shiner & 0 & 0 & 0 & 25 & 0 & 25 \\
\hline Notropis telescopis & telescope shiner & 0 & 0 & 0 & 1 & 0 & 1 \\
\hline Rhinichthys atratulus & blacknose dace & 0 & 2 & 3 & 4 & 2 & 11 \\
\hline Semotilus atromaculatus & creek chub & 9 & 5 & 0 & 0 & 0 & 14 \\
\hline \multicolumn{8}{|l|}{ Catostomidae } \\
\hline Hypentilium nigricans & northern hogsucker & 0 & 0 & 0 & 0 & 1 & 1 \\
\hline \multicolumn{8}{|l|}{ Salmonidae } \\
\hline Salvelinus fontinalis & brook trout & 0 & 0 & 1 & 0 & 0 & 1 \\
\hline \multicolumn{8}{|l|}{ Centrarchidae } \\
\hline Lepomis cyanellus & green sunfish & 19 & 16 & 0 & 0 & 0 & 35 \\
\hline Lepomis gibbosus & pumpkinseed & 0 & 2 & 0 & 0 & 0 & 2 \\
\hline Lepomis macrochirus & bluegill & 0 & 1 & 0 & 0 & 0 & 1 \\
\hline Micropterus dolomieu & smallmouth bass & 2 & 1 & 7 & 9 & 0 & 19 \\
\hline \multicolumn{8}{|l|}{ Percidae } \\
\hline \multirow[t]{2}{*}{ Etheostoma caeruleum } & rainbow darter & 0 & 9 & 0 & 0 & 13 & 22 \\
\hline & Total & 38 & 37 & 11 & 66 & 34 & 186 \\
\hline
\end{tabular}




\section{New River Gorge National River Fish Data}

\section{Short Creek}

\begin{tabular}{|c|c|c|c|c|c|c|c|}
\hline \multirow[b]{2}{*}{ Species } & \multirow[b]{2}{*}{ Common Name } & \multicolumn{5}{|c|}{ Seasons } & \multirow[b]{2}{*}{ Total } \\
\hline & & $\begin{array}{r}\text { Fall } \\
2001 \\
\end{array}$ & $\begin{array}{c}\text { Spring } \\
2002\end{array}$ & $\begin{array}{c}\text { Summer } \\
2002\end{array}$ & $\begin{array}{r}\text { Fall } \\
2002 \\
\end{array}$ & $\begin{array}{c}\text { Spring } \\
2003\end{array}$ & \\
\hline \multicolumn{8}{|l|}{ Cyrpinidae } \\
\hline Semotilus atromaculatus & creek chub & 1 & 3 & 1 & 0 & 0 & 5 \\
\hline \multicolumn{8}{|l|}{ Ictaluridae } \\
\hline Pylodictus olivaris & flathead catfish & 0 & 1 & 0 & 0 & 0 & 1 \\
\hline \multicolumn{8}{|l|}{ Centrarchidae } \\
\hline Lepomis cyanellus & green sunfish & 0 & 1 & 0 & 0 & 0 & 1 \\
\hline Micropterus dolomieu & smallmouth bass & 0 & 1 & 0 & 0 & 0 & 1 \\
\hline \multicolumn{8}{|l|}{ Percidae } \\
\hline \multirow[t]{2}{*}{ Etheostoma caeruleum } & rainbow darter & 0 & 4 & 0 & 0 & 0 & 4 \\
\hline & Total & 1 & 10 & 1 & 0 & 0 & 12 \\
\hline
\end{tabular}




\section{New River Gorge National River Fish Data}

\section{Wolf Creek}

\section{Seasons}

\begin{tabular}{|c|c|c|c|c|c|c|c|}
\hline Species & Common Name & $\begin{array}{l}\text { Fall } \\
2001 \\
\end{array}$ & $\begin{array}{c}\text { Spring } \\
2002 \\
\end{array}$ & $\begin{array}{c}\text { Summer } \\
2002 \\
\end{array}$ & $\begin{array}{l}\text { Fall } \\
2002 \\
\end{array}$ & $\begin{array}{c}\text { Spring } \\
2003 \\
\end{array}$ & Total \\
\hline \multicolumn{8}{|l|}{ Cyprinidae } \\
\hline Campostoma anomalum & central stoneroller & 7 & 0 & 3 & 6 & 1 & 17 \\
\hline Cyprinella galactura & whitetail shiner & 0 & 0 & 0 & 40 & 0 & 42 \\
\hline Notropis telescopus & telescope shiner & 0 & 0 & 0 & 1 & 0 & 1 \\
\hline Rhinicthys atratulus & blacknose dace & 3 & 9 & 18 & 210 & 36 & 276 \\
\hline Semotilus atromaculatus & creek chub & 0 & 0 & 2 & 2 & 1 & 5 \\
\hline \multicolumn{8}{|l|}{ Salmonidae } \\
\hline Salmo trutta & brown trout & 2 & 0 & 0 & 0 & 1 & 3 \\
\hline \multicolumn{8}{|l|}{ Centrarchidae } \\
\hline Lepomis cyanellus & green sunfish & 3 & 2 & 2 & 4 & 0 & 11 \\
\hline Lepomis gibbosus & pumpkinseed & 0 & 2 & 0 & 1 & 0 & 3 \\
\hline \multirow[t]{2}{*}{ Micropterus dolomieu } & smallmouth bass & 5 & 16 & 1 & 21 & 2 & 45 \\
\hline & Total & 20 & 29 & 26 & 285 & 43 & 403 \\
\hline
\end{tabular}


CURRICULUM VitAE

David I. Wellman, Jr.

\section{Education:}

May 2004

West Virginia University

Division of Forestry

M.S. Fisheries Science

August 2001

University of Kansas

Department of Environmental Studies

B.S. Environmental Science, emphasis on aquatic ecology/water resources

\section{Work/Research Experience:}

Fisheries Biologist

Compliance Monitoring Laboratories, Inc.

50 Caney Branch Road

Chapmanville, WV 25508

September 2003 - present

Plan, organize, and lead fish and benthic surveys, stream delineations, and ephemeral/intermittent conversion zone determinations and write associated reports for private companies and public agencies. Aid in writing stream mitigation plans to improve fish habitat and also aid in writing Environmental Assessments. Use ArcGIS on a regular basis to develop maps of study areas and for use in stream mitigation plans.

\section{Biology GS-6 - Student Career Experience Program (SCEP)}

U.S. Geological Survey, Leetown Science Center, Biological Resources Division 11700 Leetown Road, Kearneysville, WV 25430

Supervisor: Dr. Barnaby Watten - Fisheries Biologist/Engineer

July 2003 - September 2003

I worked in the Restoration Technology Branch and aided in the construction, maintenance, and testing of equipment designed to treat streams impacted by acid mine drainage, acid precipitation, hydropower dam facilities and for the control of exotic species (e.g. zebra mussels and Asian clams). Conducted chemistry experiments to observe the fixation of phosphorus using flocs produced by the neutralization of acid mine drainage. Work time was shared with the U.S. Geological Survey, Water Resources Division in Charleston, WV. 


\section{Biology/Hydrology GS-6 - Student Career Experience Program (SCEP)}

U.S. Geological Survey, Water Resources Division

11 Dunbar Street, Charleston, WV 25301

Supervisor: Mr. Hugh Bevans

January 1997 - August 1999 and May 2001 - September 2003

Responsibilities consisted of field trip preparation and surface water collection using part per billion protocols, recording water quality parameters with Hydrolabs, ecological surveys of streams (fish and invertebrates), habitat and geomorphological surveys of streams, servicing Data Collection Platforms (DCP) for continual water data, groundwater inventorying, water well pump test, gage house construction, boat operation/maintenance and data entry.

\section{Graduate Research Assistant}

West Virginia University, Division of Forestry

U.S. Geological Survey - West Virginia Cooperative Fish and Wildlife Research Unit

POB 6125322 Percival Hall, Morgantown, WV 26506

Major Professor: Dr. Stuart Welsh

August 2001 - May 2004

Examined the order and timing of recolonization among fish species and if recolonization trends differed between native and nonnative fishes in flood-impacted tributaries of the New River Gorge National River, West Virginia. A synthesis of the New River Gorge's fish fauna was also updated and ArcGIS was used to create distributional maps and examine distributional patterns of fishes. A backpack electro-fisher was used to survey fish communities. Aided fellow graduate students with the following:

- Collected American eels to determine seasonal movement patterns.

- Surveyed fish and aquatic invertebrate communities to examine impacts of major highway construction

- Surveyed portions of the Elk River, West Virginia and tributaries in attempts to establish preferred habitat of the crystal and spotted darters.

- Surveyed fish communities in the Ohio River to determine preferred over winter habitat.

\section{Hydrology GS-6 - Student Career Experience Program (SCEP)}

U.S. Geological Survey, Water Resources Division

4821 Quail Crest Place, Lawrence, Kansas 66049

Supervisor: David Mau

August 1999 - May 2001

Conducted bathymetric surveys of reservoirs and analyzed bathymetric data using Hypack Max Software to reconstruct sediment and pesticide mass loading. Water quality samples using parts per billion protocols and sediment core samples were taken and analyzed for pesticides, trace elements, nutrients, fecal coliform, E. coli, phytoplankton, and chlorophyll a, b, c from reservoirs and streams. Continual water quality data were recorded with YSI 6600 and Data Collection Platforms (DCP). Became proficient in trouble-shooting YSI 6600 and DCP to ensure that satellite telemetry worked and data were transmitted. Other responsibilities included discharge 
measurements, gage house construction/maintenance, boat operation/maintenance and training of lower grade employees.

\section{Papers Presented and Written:}

1998 U.S. Geological Survey

Public Liaison Meeting

Charleston, West Virginia

2002 American Fisheries Society

Southern Division Mid-Year Meeting

Little Rock, Arkansas

2002 West Virginia Wildlife Society

Annual Meeting

Weston, West Virginia

2002 USGS - West Virginia Cooperative Fish and Wildlife Research Annual

Meeting

Morgantown, West Virginia

2002 American Fisheries Society Annual Meeting Baltimore, Maryland

2002 National Park Service

New River Gorge National River

Glen Jean, West Virginia

$20022^{\text {nd }}$ Annual Future Fisheries

Professional Colloquium

Cookeville, Tennessee
Oral Presentation:

Bacteria in Ground and Surface Water

David I. Wellman

Oral Presentation:

Distributions of Fishes of the New River

Gorge National River, West Virginia,

Following Major Flood Events

David I. Wellman and Stuart A. Welsh

Oral Presentation

Distributions of Native and Nonnative

Fishes in the New River Gorge National

River

David I. Wellman and Stuart A. Welsh

Oral Presentation:

Relationships Among Fish Distributions, Watershed Characteristics, and Floods in the New River Gorge National River David I. Wellman and Stuart A. Welsh

Oral Presentation:

Fish Distributions in the New River Gorge National River in Relation to Watershed and Stream Characteristics

David I. Wellman and Stuart A. Welsh

Oral Presentation:

Progress on Fish Recolonization within

Tributaries of the New River

David I. Wellman and Stuart A. Welsh

Oral Presentation:

Post-flood recolonization of fishes in high gradient, Appalachian Streams

David I. Wellman and Stuart A. Welsh 
2003 Annual Tri-State Fisheries Meeting Ashland, Kentucky

2003 - Final paper presented to the National Park Service, New River Gorge National River

Glen Jean, West Virginia
Oral Presentation:

Recovery of Fishes in Small, High Gradient Streams Following Major Flood Events David I. Wellman and Stuart A. Welsh

Written:

Fishes of the New River Gorge National River

Stuart A. Welsh, David I. Wellman, and Dan A. Cincotta

\section{Additional Training and Skills:}

2002 - Department of Interior Electrofishing Safety Course

2002 - American Red Cross first aid and adult CPR

2001 - West Virginia University Advanced Ichthyology

2000 - U.S. Geological Survey Defensive Drivers Course

1999 - Department of the Interior MOCC boaters training

1997 - U.S. Geological Survey Water Quality Principles Class

\section{Computer Skills:}

- ArcGIS

- Terrain Navigator

- Capture Statistical Software

- Microsoft applications (Word, Excel, Power Point)

- Hypack Max Bathymetry Software

\section{Organizational Affiliations:}

American Fisheries Society

West Virginia University Student Chapter of the American Fisheries Society

\section{Awards:}

1997 - U.S. Geological Survey STAR Award 1998 - U.S. Geological Survey STAR Award
Student member, 1997 - present

Member, 2001 - present 